\title{
Zinc and Cadmium in Benthic Foraminifera as Tracers of Ocean Paleochemistry
}

\author{
By \\ Thomas Mathew Marchitto, Jr. \\ B.S., Yale University, 1994 \\ Submitted in partial fulfillment of the requirements for the dual degrees of \\ Doctor of Philosophy \\ at the \\ MASSACHUSETTS INSTITUTE OF TECHNOLOGY \\ and the

\section{WOODS HOLE OCEANOGRAPHIC INSTITUTION}

February, 2000

(C) 1999 Thomas M. Marchitto, Jr. All rights reserved

The author hereby grants to MIT and WHOI permission to reproduce paper and electronic copies of this thesis in whole or in part and to distribute them publicly.

Signature of Author

Joint Pfogram in Oceanography

Massachusetts Institute of Technology

nd Woods Hole Oceanographic Institution

Certified by

William B. Curry and Delia W. Oppo

Thesis Supervisors

Woods Hole Oceanographic Institution

Accepted by

Timothy L. Grove

Chair, Joint Committee for Marine Geology and Geophysics

Massachusetts Institute of Technology 


\title{
Zinc and Cadmium in Benthic Foraminifera as Tracers of Ocean Paleochemistry
}

\author{
By \\ Thomas Mathew Marchitto, Jr. \\ Submitted in partial fulfillment of the requirements for the dual degrees of \\ Doctor of Philosophy at the Massachusetts Institute of Technology and the \\ Woods Hole Oceanographic Institution, October 1999
}

\begin{abstract}
Benthic foraminiferal $\delta^{13} \mathrm{C}, \mathrm{Cd} / \mathrm{Ca}$, and $\mathrm{Ba} / \mathrm{Ca}$ are important tools for reconstructing nutrient distributions, and thus ocean circulation, on glacial-interglacial timescales. However, each tracer has its own "artifacts" that can complicate paleoceanographic interpretations. It is therefore advantageous to measure multiple nutrient proxies with the aim of separating the various complicating effects. $\mathrm{Zn} / \mathrm{Ca}$ is introduced as an important aid toward this goal.

Benthic (Hoeglundina elegans) $\mathrm{Cd} / \mathrm{Ca}$ ratios from the Bahama Banks indicate that the North Atlantic subtropical gyre was greatly depleted in nutrients during the last glacial maximum (LGM). A high-resolution $\mathrm{Cd} / \mathrm{Ca}$ record from $965 \mathrm{~m}$ water depth suggests that Glacial North Atlantic Intermediate Water formation was strong during the LGM, weakened during the deglaciation, and strengthened again during the Younger Dryas cold period. Comparison of $\mathrm{Cd} / \mathrm{Ca}$ and $\delta^{13} \mathrm{C}$ data reveals apparent short-term changes in carbon isotopic air-sea signatures.

Benthic foraminiferal $\mathrm{Zn} / \mathrm{Ca}$ could be a sensitive paleoceanographic tracer because deep water masses have characteristic $\mathrm{Zn}$ concentrations that increase about ten-fold from the deep North Atlantic to the deep North Pacific. A "core top calibration" shows that $\mathrm{Zn} / \mathrm{Ca}$ is controlled by bottom water dissolved $\mathrm{Zn}$ concentration and, like $\mathrm{Cd} / \mathrm{Ca}$ and $\mathrm{Ba} / \mathrm{Ca}$, by bottom water saturation state with respect to calcite. Since $\mathrm{Zn} / \mathrm{Ca}$ responds to a different range of saturation states than $\mathrm{Cd} / \mathrm{Ca}$, the two may be used together to evaluate changes in deep water carbonate ion $\left(\mathrm{CO}_{3}{ }^{2-}\right)$ concentration.

$\mathrm{Zn} / \mathrm{Ca}$ and $\mathrm{Cd} / \mathrm{Ca}$ ratios in the benthic foraminifer Cibicidoides wuellerstorfi exhibit large fluctuations over the past 100,000 years in a deep $(3851 \mathrm{~m})$ eastern equatorial Pacific sediment core. The data imply that bottom water $\mathrm{CO}_{3}{ }^{2-}$ concentrations were lowest during glacial Marine Isotope Stage 4 and highest during the last deglaciation. LGM $\mathrm{CO}_{3}{ }^{2-}$ concentrations appear to have been within a few $\mu \mathrm{mol} \mathrm{kg}{ }^{-1}$ of modern values.
\end{abstract}


Deep North Atlantic $\mathrm{Cd} / \mathrm{Ca}$ ratios imply much higher nutrient concentrations during the LGM. Although such data have usually been explained by a northward penetration of Southern Ocean Water (SOW), it has been suggested that they could result from increased preformed nutrient levels in the high-latitude North Atlantic or by increased aging of lower North Atlantic Deep Water (NADW). Glacial $\mathrm{Zn} / \mathrm{Ca}$ data, however, require a substantially increased mixing with SOW and thus a reduction in NADW formation. Large changes in carbon isotopic air-sea exchange are invoked to reconcile benthic $\delta^{13} \mathrm{C}$ and trace metal data.

Thesis Supervisors: William B. Curry, Senior Scientist, WHOI

Delia W. Oppo, Associate Scientist, WHOI 


\section{Acknowledgements}

I owe sincere thanks to many people who have helped me through this thesis. As my main advisor, Bill Curry provided excellent advice, unwavering support, and an appreciation for the bigger picture. I am especially grateful for his willingness to let me steer my work down unpredictable paths. Co-advisor Delia Oppo was always there when I had a question (and I had many) or wanted to discuss the intricacies of some trace metal data. She also kindly allowed me to run unfettered in her AA lab. Ed Boyle generously shared his old, "not ready for prime-time" $\mathrm{Zn} / \mathrm{Ca}$ data, which helped motivate this work (and get it funded). He also provided a great deal of laboratory advice, including the necessity of contamination paranoia. Dan McCorkle and Lloyd Keigwin offered important insights and advice in molding this thesis.

Numerous other scientists have provided valuable input at various stages, through discussions and/or reviews of manuscripts, including (but not limited to): Pat Lohmann, Jerry McManus, Bob Anderson, Wally Broecker, Patrick De Deckker, Laurent Labeyrie, David Lea, and Rainer Zahn.

Unpublished seawater data used in this thesis were provided by Pat Lohmann (Bahama Banks P); Phil Yeats and John Dalziel (North Atlantic Zn and Si); and Dan McCorkle, Greg Eisheid, and Zofia Mlodzinska (KNR159-5 $\Sigma \mathrm{CO}_{2}$, Alk, Si, P, and salinity). Bill Curry, Pat Lohmann, and Delia Oppo provided foraminiferal samples from the Atlantic; Lloyd Keigwin provided foraminiferal samples from the northwest Pacific; and the Ocean Drilling Program supplied numerous sediment samples from around the world. I thank the scientific staff and crew of $R V$ Knorr Cruise 159-5 for helping to obtain precious multicore samples, and also for showing me how to operate a successful cruise.

Rindy Ostermann, Marti Jeglinski, Sue Prew, and Lu Ping Zou assisted me in innumerable ways, especially when it came to picking forams, loading and running the mass spectrometer, solving computer problems, and filling out forms. Julia Westwater, Stella Callagee, Marcey Simon, Marsha Bissonette, Shirley Waskilewicz, Ronni Schwartz, and Jake Peirson made any Education Office bureaucracy virtually transparent.

Some of a graduate student's most influential colleagues are his or her fellow students. I thank Jess Adkins, Danny Sigman, and Chris Weidman for sage guidance and inspiration. Michael Horowitz taught me much of what I know about foraminiferal trace metal technique. Longtime housemates and great friends Lou St. Laurent and Mike Braun have always kept things fun, even when we had to move three times in 13 months (I guess Jenkins Pond was worth it, except for that final night). Joe Warren, along with Lou and Mike, made our band Vomelette what it is today (defunct). Thanks to Joe, WHOI '94, and all the other Polynesian punks for some great parties through the years. Most of all, Liz Kujawinski has been a great friend and companion through the good and the bad. Some day we will make it to Wrigley, Liz.

Old friends from Connecticut offered needed diversions from the world of science. I am especially grateful to Frank Saunders, Allan Harris, John Blakeslee, and Paul Blakeslee for many hours of madness, both on-Cape and off. Additional thanks go to 
the G\&G softball team, the Kidd (despite the service), Liam's (despite Puff the Magic Dragon), the Boston Red Sox, and Metallica.

Finally, I am eternally grateful to my parents for their unconditional support of everything I have wanted to do, and their encouraging belief that I could do it.

$\mathrm{AII}, \mathrm{CHN}$, and KNR cores are curated at WHOI with support from the National Science Foundation, the Office of Naval Research, and the United States Geological Survey. This work was supported by a JOI/USSAC Ocean Drilling Fellowship (subgrant JSG-CY 12-4), the R. H. Cole Ocean Ventures Fund, the Joint Program Education Office, and the National Science Foundation (grants OCE-9402804 and OCE-9503135 to W. Curry, and grant OCE-9633499 to D. Oppo). 


\section{CONTENTS}

Abstract

Acknowledgements

Introduction

Background 9

Zn as a paleoceanographic tracer $\quad 11$

$\begin{array}{ll}\text { References } & 13\end{array}$

Chapter 1. Millennial-scale changes in North Atlantic circulation since the last glaciation

$\begin{array}{ll}\text { Reprint from Nature, 393: 557-561 (1998) } & 17\end{array}$

Supplementary information: radiocarbon and calibrated ages $\quad 22$

Additional results from core OC205-2-103GGC 23

$\begin{array}{ll}\text { Revised chronology } & 23\end{array}$

Benthic $\mathrm{Cd} / \mathrm{Ca}$ and stable isotopes $\quad 24$

$\begin{array}{ll}\text { Conclusions } & 25\end{array}$

References $\quad 26$

$\begin{array}{ll}\text { Figures } & 27\end{array}$

Tables $\quad 30$

Chapter 2. Zinc concentrations in benthic foraminifera reflect seawater chemistry

$\begin{array}{ll}\text { Abstract } & 39\end{array}$

Introduction $\quad 39$

$\begin{array}{ll}\text { Dissolved } \mathrm{Zn} \text { in seawater } & 40\end{array}$

Materials and methods $\quad 41$

Results and discussion $\quad 43$

$\mathrm{Zn} / \mathrm{Ca}$ in $C$. wuellerstorfi and Uvigerina spp. 43

$\mathrm{Cd} / \mathrm{Ca}$ and its relationship to seawater $\Delta \mathrm{CO}_{3}{ }^{2-} \quad 44$

$\triangle \mathrm{CO}_{3}{ }^{2-}$ effect in "live" benthic foraminifera 47

Application to paleoceanography $\quad 50$

$\mathrm{Zn} / \mathrm{Ca}$ in other benthic foraminiferal species $\quad 53$

Conclusions $\quad 54$

References $\quad 55$

$\begin{array}{ll}\text { Figures } & 61\end{array}$

Tables $\quad 86$ 
Chapter 3. Glacial-interglacial records of benthic foraminiferal $\mathrm{Zn} / \mathrm{Ca}$ and $\mathrm{Cd} / \mathrm{Ca}$ from the deep eastern equatorial Pacific: constraints on oceanic carbonate ion concentrations

Abstract

Introduction

Atmospheric $\mathrm{CO}_{2}$ and the carbonate system in seawater 93

Constraining paleo- $\mathrm{CO}_{3}{ }^{2-}$ using deep Pacific $\mathrm{Zn} / \mathrm{Ca}$ and $\mathrm{Cd} / \mathrm{Ca} \quad 96$

Study area and previous stable isotope work $\quad 98$

Materials and methods $\quad 99$

Results and discussion $\quad 100$

$\begin{array}{ll}\mathrm{Mn} / \mathrm{Ca} \text { and possible authigenic contamination } & 100\end{array}$

$\mathrm{Zn} / \mathrm{Ca}$ and $\mathrm{Cd} / \mathrm{Ca}$ in C. wuellerstorfi 102

$\Delta \mathrm{CO}_{3}{ }^{2-}$ values inferred from C. wuellerstorfi 103

$\begin{array}{ll}\text { Implications for modeling atmospheric } \mathrm{CO}_{2} & 107\end{array}$

$\begin{array}{ll}\text { Possible constraints on oceanic } \mathrm{Zn} \text { and Cd inventories } & 109\end{array}$

$\mathrm{Zn} / \mathrm{Ca}$ and $\mathrm{Cd} / \mathrm{Ca}$ in $N$. umbonifera and Uvigerina 111

Conclusions 112

References $\quad 113$

Figures $\quad 120$

Tables 136

Chapter 4. Depth transects of benthic foraminiferal $\mathrm{Zn} / \mathrm{Ca}$ and $\mathrm{Cd} / \mathrm{Ca}$ in the North Atlantic: deep water reorganization during the last glacial maximum

Abstract

Introduction 141

$\begin{array}{ll}\text { Study area and previous work } & 144\end{array}$

Materials and methods 146

Results and discussion $\quad 147$

$\begin{array}{ll}\mathrm{Cd} / \mathrm{Ca} \text { profiles } & 147\end{array}$

$\begin{array}{ll}\text { Three glacial circulation models } & 149\end{array}$

$\mathrm{Zn} / \mathrm{Ca}$ and inferred glacial circulation $\quad 154$

$\begin{array}{ll}\text { Implications for glacial Atlantic } \delta^{13} \mathrm{C} & 155\end{array}$

$\begin{array}{ll}\text { Conclusions } & 157\end{array}$

References 158

Figures 164

Tables $\quad 180$

$\begin{array}{ll}\text { Summary } & 185\end{array}$

$\begin{array}{ll}\text { References } & 187\end{array}$

Appendix 1. Analytical methods and precision 189

Appendix 2. Calculations for the carbonate system in seawater 199 


\section{Introduction}

\section{Background}

The importance of ocean circulation in influencing glacial climate has been hypothesized for well over a century. Paleoclimate pioneer James Croll (1875) called upon ocean currents to amplify the cooling started by astronomical forcing, estimating that "The stoppage of the Gulf Stream would deprive the Atlantic of $77,479,650,000,000,000,000$ foot-pounds of energy in the form of heat per day." Only in recent years, however, have we begun to understand the history of ocean circulation. Much of our current knowledge has come from the chemical study of $\mathrm{CaCO}_{3}$ shells of planktonic and benthic foraminifera. For example, benthic $\delta^{13} \mathrm{C}$ measurements suggest that during the last glacial maximum (LGM, $\sim 22,000$ cal yr BP), North Atlantic Deep Water (NADW) was largely replaced by a shallower Glacial North Atlantic Intermediate Water (GNAIW), allowing the glacial analogue of Antarctic Bottom Water (AABW) to penetrate farther north (e.g., Curry and Lohmann, 1982; Boyle and Keigwin, 1982, 1987; Oppo and Fairbanks, 1987; Duplessy et al., 1988; Boyle, 1992; Oppo and Lehman, 1993). Such changes likely had major effects on the earth's climate because NADW formation is responsible for a large amount of meridional heat transport (e.g., Imbrie et al., 1992, 1993).

Boyle and Keigwin (1982) introduced the use of trace metals, namely $\mathrm{Cd}$, to

estimate the past distribution and circulation of deep water masses. The concentration of dissolved $\mathrm{Cd}$ is near zero in modern surface waters, increases rapidly to a maximum near $\sim 1000 \mathrm{~m}$ depth, and decreases slightly in deeper waters (Boyle et al, 1976; Bruland, 1980). This profile is very similar to that of $P$, and the two elements co-vary strongly throughout the world's oceans (Boyle, 1988). Both are removed from surface waters by biogenic particles and transported to deeper waters as the particles sink and decay. Patterns of deep water formation and circulation thus imprint deep water masses with characteristic $\mathrm{Cd}$ and $\mathrm{P}$ concentrations. Lowest values are found in the North Atlantic, while highest levels are in the deep North Pacific, in the ocean's oldest waters. Hester and Boyle (1982) showed that $\mathrm{Cd}$ is incorporated into benthic foraminiferal shells, 
presumably by substitution for $\mathrm{Ca}$. Because this incorporation is proportional to the $\mathrm{Cd}$ concentration of ambient seawater (via depth-dependent partition coefficients), paleoceanic distributions of $\mathrm{Cd}$ can be reconstructed. Boyle and Keigwin (1982) found strong $\mathrm{Cd} / \mathrm{Ca}$ increases in the deep North Atlantic during severe glaciations, suggesting increased $\mathrm{Cd}$ levels and therefore decreased NADW intensities. Subsequent $\mathrm{Cd} / \mathrm{Ca}$ studies have added much to our understanding of deep circulation during glacial periods (e.g., Boyle and Keigwin, 1985/6, 1987; Boyle, 1988, 1992; Oppo and Rosenthal, 1994; Bertram et al., 1995; Beveridge et al., 1995; Boyle et al., 1995; Lynch-Stieglitz et al., 1996; Rosenthal et al., 1997).

Lea and Boyle (1989) applied similar methods to develop benthic foraminiferal $\mathrm{Ba} / \mathrm{Ca}$ as a paleotracer. Dissolved $\mathrm{Ba}$ is partially depleted in surface waters and increases to maxima below $2000 \mathrm{~m}$ (Chan et al., 1977); its distribution closely resembles that of alkalinity (Lea and Boyle, 1989). Ba is removed from shallow waters mainly by barite $\left(\mathrm{BaSO}_{4}\right)$ formation in decaying organic matter (Dehairs et al., 1980; Bishop, 1988), and alkalinity is removed by $\mathrm{CaCO}_{3}$ formation. Both are regenerated at depth as their carrier phases dissolve, and deep water masses have characteristic $\mathrm{Ba}$ and alkalinity values. Lea and Boyle (1989) showed that benthic foraminifera record bottom water $\mathrm{Ba}$ concentrations, allowing $\mathrm{Ba} / \mathrm{Ca}$ to be used as a deep water tracer (Lea and Boyle, 1990a, b) and possibly as a proxy for paleoalkalinity (Lea, 1993, 1995).

Unfortunately, the existing deep water tracers give discordant information in some regions. In the deep Southern Ocean, $\delta^{13} \mathrm{C}$ suggests much higher nutrient contents during the LGM, while Cd/Ca implies no major change (e.g., Curry et al., 1988; Boyle, 1992; Boyle and Rosenthal, 1996). In the deep Pacific, $\delta^{13} \mathrm{C}$ suggests that glacial nutrient concentrations were similar to or slightly higher than today, but $\mathrm{Cd} / \mathrm{Ca}$ calls for somewhat lower levels in the eastern tropical Pacific and much lower levels in the northwest Pacific (Keigwin, 1987; Boyle, 1992). Various artifacts have been proposed to explain such discrepancies, including microhabitat and air-sea exchange influences on $\delta^{13} \mathrm{C}$ (Mackensen et $a l ., 1993$; Charles et al., 1993) and calcite undersaturation (or dissolution) effects for $\mathrm{Cd} / \mathrm{Ca}$ and $\mathrm{Ba} / \mathrm{Ca}$ (McCorkle et al., 1995). Uncertainties 
surrounding the glacial oceanic means of $\delta^{13} \mathrm{C}$ (Duplessy et al., 1988) and dissolved $\mathrm{Cd}$ (Boyle, 1992) may also be responsible for some of the apparent disagreement. In addition, recent work suggests that changes in seafloor barite dissolution can complicate the use of $\mathrm{Ba} / \mathrm{Ca}$ to reconstruct deep circulation (Martin and Lea, 1998). $\mathrm{Zn} / \mathrm{Ca}$ measurements can help to resolve some of these conflicts by adding independent information about bottom water chemistry.

\section{Zn as a paleoceanographic tracer}

$\mathrm{Zn}$ is well-suited to be another useful paleotracer. Its dissolved profile in the modern ocean is near zero in most surface waters and increases to maximum concentrations below $1000 \mathrm{~m}$ depth (Bruland et al., 1978). The distribution of $\mathrm{Zn}$ is very similar to that of $\mathrm{Si}$, and correlations between the two elements are as high as $\mathrm{r}=0.996 \mathrm{in}$ the Pacific (Bruland, 1980). Both elements are removed from surface waters by biological productivity: $\mathrm{Zn}$ is an important nutrient used in metalloenzymes such as carbonic anhydrase (e.g., Bruland et al., 1991; Morel et al., 1994), and Si is incorporated into the opal tests of diatoms and radiolarians. Deep water formation and circulation create large gradients of $\mathrm{Zn}$ and $\mathrm{Si}$ in the deep ocean, with dissolved $\mathrm{Zn}$ concentrations ranging from $<1 \mathrm{nmol} \mathrm{kg}{ }^{-1}$ in the deep North Atlantic (Yeats and Dalziel, unpublished data) to $>10 \mathrm{nmol} \mathrm{kg}^{-1}$ in the North Pacific (Martin et al., 1989). This gradient ( $\sim$ ten-fold) is much greater than for $\mathrm{Cd}$ ( $\sim$ five-fold; Boyle, 1988) and $\mathrm{Ba}$ ( $\sim$ three-fold; Lea and Boyle, 1989). There is a particularly large ( $\sim$ seven-fold $)$ increase in $\mathrm{Zn}$ between the deep North Atlantic and the deep Southern Ocean. Thus benthic foraminiferal $\mathrm{Zn} / \mathrm{Ca}$ may be a very sensitive tracer of the relative influences of NADW and $\mathrm{AABW}$ in the deep Atlantic.

Only two benthic foraminiferal $\mathrm{Zn} / \mathrm{Ca}$ measurements have been previously published (Boyle, 1981), and one of these is certainly contaminated. No other investigator has followed up on this preliminary work, perhaps due (in part) to the difficulty of making contamination-free $\mathrm{Zn}$ measurements (Bruland et al., 1978). However, unpublished $\mathrm{Zn} / \mathrm{Ca}$ data from Boyle (personal communication) were promising 
in that they displayed some weak correlations with $\mathrm{Cd} / \mathrm{Ca}$. Those data served as one impetus for this thesis. The controls on benthic foraminiferal $\mathrm{Zn} / \mathrm{Ca}$ are explored in Chapter 2, and applications to glacial problems are made in Chapters 3 and 4. With the exception of Chapter 1 (which does not include any $\mathrm{Zn} / \mathrm{Ca}$ data) I have attempted to use $\mathrm{Zn} / \mathrm{Ca}$ and $\mathrm{Cd} / \mathrm{Ca}$ as complementary tracers. This strategy is necessary for separating the various influences on foraminiferal data. As our understanding grows, what were once complications may become new insights into the paleoceanographic record. 


\section{References}

Bertram, C. J., H. Elderfield, N. J. Shackleton, and J. A. MacDonald, Cadmium/calcium and carbon isotope reconstructions of the glacial northeast Atlantic Ocean, Paleoceanography, 10, 563-578, 1995.

Beveridge, N. A. S., H. Elderfield, and N. J. Shackleton, Deep thermohaline circulation in the low-latitude Atlantic during the last glacial, Paleoceanography, 10, 643-660, 1995.

Bishop, J. K. B., The barite-opal-organic carbon association in oceanic particulate matter, Nature, 332, 341-343, 1988.

Boyle, E. A., Cadmium, zinc, copper, and barium in foraminifera tests, Earth Planet. Sci. Lett., 53, 11-35, 1981.

Boyle, E. A., Cadmium: Chemical tracer of deepwater paleoceanography, Paleoceanography, 3, 471-489, 1988.

Boyle, E. A., Cadmium and $\delta^{13} \mathrm{C}$ paleochemical ocean distributions during the Stage 2 glacial maximum, Annu. Rev. Earth Planet. Sci., 20, 245-287, 1992.

Boyle, E. A., and L. D. Keigwin, Deep circulation of the North Atlantic over the last 200,000 years: Geochemical evidence, Science, 218, 784-787, 1982.

Boyle, E. A., and L. D. Keigwin, Comparison of Atlantic and Pacific paleochemical records for the last 215,000 years: changes in deep ocean circulation and chemical inventories, Earth Planet. Sci. Lett., 76, 135-150, 1985/86.

Boyle, E. A., and L. D. Keigwin, North Atlantic thermohaline circulation during the last 20,000 years linked to high latitude surface temperature, Nature, 330, 35-40, 1987.

Boyle, E. A., and Y. Rosenthal, Chemical hydrography of the South Atlantic during the last glacial maximum: $\mathrm{Cd}$ vs. $\delta^{13} \mathrm{C}$, in The South Atlantic: Present and Past Circulation, edited by G. Wefer et al., pp. 423-443, Springer-Verlag, Berlin, 1996.

Boyle, E. A., F. R. Sclater, and J. M. Edmond, On the marine geochemistry of cadmium, Nature, 263, 42-44, 1976.

Boyle, E. A., L. Labeyrie, and J.-C. Duplessy, Calcitic foraminiferal data confirmed by cadmium in aragonitic Hoeglundina: Application to the last glacial maximum in the northern Indian Ocean, Paleoceanography, 10, 881-900, 1995. 
Bruland, K. W., Oceanographic distributions of cadmium, zinc, nickel, and copper in the North Pacific, Earth Planet. Sci. Lett., 47, 176-198, 1980.

Bruland, K. W., G. A. Knauer, and J. H. Martin, Zinc in north-east Pacific water, Nature, 271, 741-743, 1978.

Bruland, K. W., J. R. Donat, and D. A. Hutchins, Interactive influences of bioactive trace metals on biological production in oceanic waters, Limnol. Oceanogr., 36 , 1555-1577, 1991.

Chan, L. H., D. Drummond, J. M. Edmond, and B. Grant, On the barium data from the Atlantic GEOSECS Expedition, Deep-Sea Res., 24, 613-649, 1977.

Charles, C. D., J. D. Wright, and R. G. Fairbanks, Thermodynamic influences on the marine carbon isotope record, Paleoceanography, 8, 691-697, 1993.

Croll, J., Climate and Time, D. Appleton \& Co., New York, 1875.

Curry, W. B., and G. P. Lohmann, Carbon isotopic changes in benthic foraminifera from the western South Atlantic: Reconstruction of glacial abyssal circulation patterns, Quat. Res., 18, 218-235, 1982.

Curry, W. B., J. C. Duplessy, L. D. Labeyrie, and N. J. Shackleton, Changes in the distribution of $\delta^{13} \mathrm{C}$ of deep water $\Sigma \mathrm{CO}_{2}$ between the last glaciation and the Holocene, Paleoceanography, 3, 317-341, 1988.

Dehairs, F., R. Chesselet, and J. Jedwab, Discrete suspended particles of barite and the barium cycle in the open ocean, Earth Plan. Sci. Lett., 49, 528-550, 1980.

Duplessy, J.-C., N. J. Shackleton, R. G. Fairbanks, L. Labeyrie, D. Oppo, and N. Kallel, Deepwater source variations during the last climatic cycle and their impact on the global deepwater circulation, Paleoceanography, 3, 343-360, 1988.

Hester, K., and E. A. Boyle, Water chemistry control of the $\mathrm{Cd}$ content of benthic foraminifera, Nature, 298, 260-261, 1982.

Imbrie, J., et al., On the structure and origin of major glaciation cycles 1. Linear responses to Milankovitch forcing, Paleoceanography, 7, 701-738, 1992.

Imbrie, J., et al., On the structure and origin of major glaciation cycles 2 . The $100,000-$ year cycle, Paleoceanography, 8, 699-735, 1993.

Keigwin, L. D., North Pacific deep water formation during the latest glaciation, Nature, $330,362-364,1987$. 
Lea, D. W., Constraints on the alkalinity and circulation of glacial circumpolar deep water from benthic foraminiferal barium, Glob. Biogechem. Cycles, 7, 695-710, 1993.

Lea, D. W., A trace metal perspective on the evolution of Antarctic Circumpolar Deep Water chemistry, Paleoceanography, 10, 733-747, 1995.

Lea, D. W., and E. A. Boyle, Barium content of benthic foraminifera controlled by bottom-water composition, Nature, 338, 751-753, 1989.

Lea, D. W., and E. A. Boyle, A 210,000-year record of barium variability in the deep northwest Atlantic Ocean, Nature, 347, 269-272, 1990a.

Lea, D. W., and E. A. Boyle, Foraminiferal reconstructions of barium distributions in water masses of the glacial oceans, Paleoceanography, 5, 719-742, $1990 \mathrm{~b}$.

Lynch-Stieglitz, J., A. van Geen, and R. G. Fairbanks, Interocean exchange of Glacial North Atlantic Intermediate Water: Evidence from Subantarctic $\mathrm{Cd} / \mathrm{Ca}$ and carbon isotope measurements, Paleoceanography, 11, 191-201, 1996.

Mackensen, A., H.-W. Hubberten, T. Bickert, G. Fischer, and D. K. Fütterer, The $\delta^{13} \mathrm{C}$ in benthic foraminiferal tests of Fontbotia wuellerstorfi (Schwager) relative to the $\delta^{13} \mathrm{C}$ of dissolved inorganic carbon in Southern Ocean deep water: Implications for glacial ocean circulation models, Paleoceanography, 8, 587-610, 1993.

Martin, J. H., R. M. Gordon, S. Fitzwater, and W. W. Broenkow, VERTEX: phytoplankton/iron studies in the Gulf of Alaska, Deep-Sea Res., 36, 649-680, 1989.

Martin, P. A., and D. W. Lea, Comparison of water mass changes in the deep tropical Atlantic derived from $\mathrm{Cd} / \mathrm{Ca}$ and carbon isotope records: Implications for changing Ba composition of deep Atlantic water masses, Paleoceanography, 13, 572-585, 1998.

McCorkle, D. C., P. A. Martin, D. W. Lea, and G. P. Klinkhammer, Evidence of a dissolution effect on benthic foraminiferal shell chemistry: $\delta^{13} \mathrm{C}, \mathrm{Cd} / \mathrm{Ca}, \mathrm{Ba} / \mathrm{Ca}$, and $\mathrm{Sr} / \mathrm{Ca}$ results from the Ontong Java Plateau, Paleoceanography, 10, 699-714, 1995.

Morel, F. M. M., J. R. Reinfelder, S. B. Roberts, C. P. Chamberlain, J. G. Lee, and D. Yee, Zinc and carbon co-limitation of marine phytoplankton, Nature, 369, 740$742,1994$. 
Oppo, D. W., and R. G. Fairbanks, Variability in the deep and intermediate water circulation of the Atlantic Ocean during the past 25,000 years: Northern Hemisphere modulation of the Southern Ocean, Earth Planet. Sci. Lett., 86, 1-15, 1987.

Oppo, D. W., and S. J. Lehman, Mid-depth circulation of the subpolar North Atlantic during the Last Glacial Maximum, Science, 259, 1148-1152, 1993.

Oppo, D. W., and Y. Rosenthal, $\mathrm{Cd} / \mathrm{Ca}$ changes in a deep Cape Basin core over the past 730,000 years: Response of circumpolar deepwater variability to northern hemisphere ice sheet melting?, Paleoceanography, 9, 661-675, 1994.

Rosenthal, Y. E. A. Boyle, and L. Labeyrie, Last glacial maximum paleochemistry and deepwater circulation in the Southern Ocean: Evidence from foraminiferal cadmium, Paleoceanography, 12, 787-796, 1997. 
Reprinted by permission from Nature (393: 557-561)

Copyright 1998 Macmillan Magazines Ltd.

\section{Millennial-scale changes in North Atlantic circulation since the last glaciation}

Thomas M. Marchitto Jr", William B. Curryt \& Delia W. Oppot

- Massachusets Institutc of Tedinology/Woods Hole Oceanographic Institution Joint Progran in Oceanography, Woods Hole, Massachusetts 02543, USA

$\dagger$ Woods Hole Oceanographic Institution, Woods Hole, Massachusetts 02543, USA

Ocean circulation is closely linked to climate change on glacialinterglacial and shorter timescales. Extensive reorganizations in the circulation of deep and intermediate-depth waters in the Atlantic Ocean have been hypothesized for both the last glaciation $^{1-6}$ and the subsequent Younger Dryas cold interva ${ }^{3,6-10}$, but there has been little palaeoceanographic study of the subtropical gyres $^{11-83}$. These gyres are the dominant oceanic features of winddriven circulation, and as such they reflect changes in climate and are a significant control on nutricnt cycling and, possibly, atnospheric $\mathrm{CO}_{2}$ concentrations. Here we present $\mathrm{Cd} / \mathrm{Ca}$ ratios in the shells of benthic foraminifera from the Bahama banks that confirm previous suggestions ${ }^{t 1,12}$ that nutrient concentrations in the North Atlantic subtropical gyre were much lower during the Last Glacial Maximum than they are today (up to $50 \%$ lower according to our data). These contrasting nutrient burdens imply nuch shorter residence times for waters within the thermocline of the Last Glacial Maximum. Below the glacial thermoctine, nutrient concentrations were reduced owing to the presence of Glacial North Atlantic Internediate Water. A high-resolution Cd/ Ca record from an intermediate depth indicates decreased nutrient concentrations during the Younger Dryas interval as well, mirroring opposite changes at a nearby deep site, ${ }^{3,9}$. Together, these observations suggest that the formation of deep and intermediate waters - North Atlantic Deep Water and Glacial North 


\section{letters to nature}

Atlantic Intermediate Water, respectively-wax and wane alternately on both orbital and millennial timescales.

The flanks of Little and Great Bahama banks border the Northwest Providence Channel $\left(\sim 26^{\circ} \mathrm{N}, 78^{\circ} \mathrm{W}\right)$, which connects the North Atlantic basin (Sargasso Sea) to the Florida Straits. The waters within this channel are derived from the Sargasso Sea, and can be roughly divided into two water masses: the main thermocline of the North Atlantic subtropical gyre $\{<1,000 \mathrm{~m}$ depth $)$ and the upper (Labrador Sea) component of North Atlantic Deep Water (NADW) $(\sim 1,000-2,000 \mathrm{~m}$ depth) (ref. 12). The gyre's upper thermocline waters outcrop (intersect with the base of the mixed layer) at latitudes to the north, where Ekman pumping and buoyancy flux subduct waters along deepening isopycnals to lower latitudes, following the anticyclonic circulation of the sub tropical gyre. Along this route, productivity in overlying surface waters adds decaying organic matter and nutrients. Waters near the base of the thermocline outcrop farther north (above $\sim 50^{\circ} \mathrm{N}$ ) in a region of positive wind stress curl, Ekman upwelling, and poor ventilation. These waters circulate in the subpolar gyre before entering the subtropical gyre ${ }^{14}$ and are therefore higher in nutrient and depleted in $\mathrm{O}_{2}$, creating a phosphate $\left(\mathrm{PO}_{4}^{3-}\right)$ maximum and $\mathrm{O}_{2}$ minimum near $800 \mathrm{~m}$ depth at Bahana banks". Deeper waters are largely derived from deep convection in the Labrador Sea ${ }^{15}$.

Dissolved cadmium has an oceanic distribution that is very similar to that of phosphorus (ref. I6). Typically, both elements are absent in surface waters, increase rapidly to shallow maxima $(\sim 800-1,000 \mathrm{~m}$ depth), then decrease slightly in deeper waters. Because the Cd content of overlying water is recorded by the $\mathrm{Cd} / \mathrm{Ca}$ ratio of benthic foraminifera sheill ${ }^{17}$, the nutrient content of water masses can be estimated during the past, both in terms of $\mathrm{Cd}$

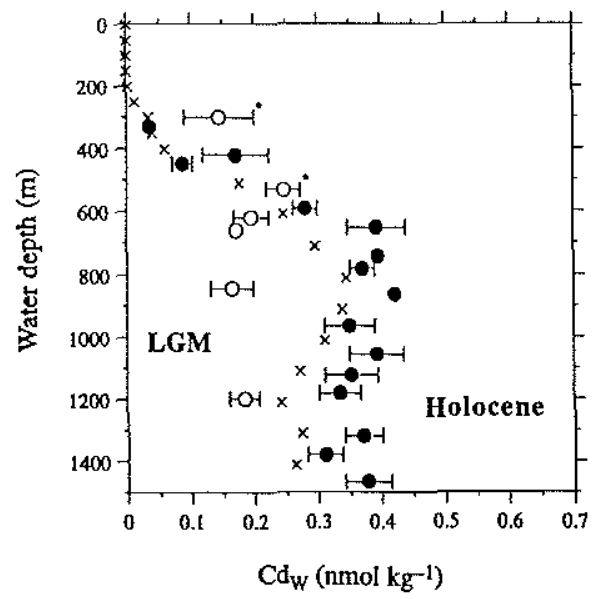

Figure 1 vertical profiles of inferred seawater cadmium concentration, $\mathrm{Cd}_{w}$

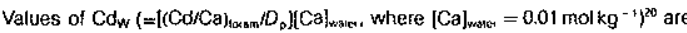
based on $H$. elegans from Late Holocene (filled circles) and LGM (open circles) sediments from the Bahama banks. Each symbol is a mean of several measure. ments, and error bars are standard errors $\left(1 \sigma / n^{1 / 2}\right)$. LGM depths are sthifted upward by $120 \mathrm{~m}$ (relative to modern core depths) to account for the glacial se level lowering ${ }^{21}$. Also shown are predicled modern $\mathrm{Cd}_{w}$ values (crosses) based on water-column $\mathrm{PO}_{4}^{3-}$ measurements and the global $\mathrm{Cd}: \mathrm{P}$ relationship ${ }^{16.18}$. Two of the 54 Holocene Cd measurements and one of the 22 LGM measurements were considered to be significantly contaminated ( $\mathrm{Cd}$ wuch higher than expected) and were not included in the means. The two LGM data marked with asterisks are biased toward high (Holocene) concentrations because core 106GGC $(534 \mathrm{~m}$ palaeodepth/is heavily bioturbated, and core $149 \mathrm{JPC}$ ( $303 \mathrm{~m}$ palaeodepth) barely penetrated glacial sediments'z. concentration and inferred $\mathrm{P}$ concentration (via the modern $\mathrm{Cd}: \mathrm{P}$ relationship) ${ }^{16,18}$. This method was first put to use in showing that the strength of NADW (which is relatively low in $\mathrm{Cd}$ and P) was substantially decreased during severe glaciations'. Here we use glacial and Holocene $\mathrm{Cd} / \mathrm{Ca}$ data from the Bahama banks to investigate the nutrient contents and circulation histories of the North Atlantic subtropical gyre and upper deep waters. Previous $\delta^{13} \mathrm{C}$ work implied that Bahamian Last Glacial Maximum (LGM) waters had $-30-60 \%$ less $\mathrm{PO}_{4}^{3-}$ than today ${ }^{11.2}$. These results were disputed, however, because in addition to reflecting reduced nutrient levels, high $\delta^{13} \mathrm{C}$ values can result from colder temperatures of air $\rightarrow$ sea $\mathrm{CO}_{2}$ exchange ${ }^{19}$. Cd/Ca ratios have the advantage of being unaffected by such thermodynamic artefacts.

A suite of 15 sediment cores and grab samples span the depth range $334-1,468 \mathrm{~m}$ on the Bahama banks. Previous $\delta^{18} \mathrm{O}$ measurements on individual benthic foraminifera shells identified the late Holocene and LGM sections of each core ${ }^{12}$. We picked samples of the aragonitic benthic foraminifer Hoeglundina elegans from these two time periods. This species faithfully records bottom-water $\mathrm{Cd}$ concentrations with an apparent partition coefficient $D_{\mathrm{p}}=\left[(\mathrm{Cd} / \mathrm{Ca})_{\text {foram }} /(\mathrm{Cd} / \mathrm{Ca})_{\text {water }}\right] \approx 1.0$ (ref. 18). This $D_{\mathrm{p}}$ shows little or no dependence on water depth, in contrast to calcitic species which vary between 1.3 and 2.9 (ref. 20). Shells of H. elegans are also less prone to contamination than calcitic species, mainly because they appear to be immune to $\mathrm{MnCO}_{3}$ overgrowths which add sedimentary $\mathrm{Cd}$ that is not effectively removed by cleaning ${ }^{18}$.

A total of 54 late Holocene $\mathrm{Cd} / \mathrm{Ca}$ measurements were made on H. elegans from the 15 core-tops. The resulting water-column profile of the inferred seawater $\mathrm{Cd}$ concentration, $\mathrm{Cd}_{\mathrm{w}}$ follows the predicted profile (based on seawater $\left[\mathrm{PO}_{4}^{3-}\right]$ measturements) quite closely (Fig. 1). Mean $\mathrm{Cd}_{\mathrm{w}}$ values range from $0.04 \mathrm{nmol} \mathrm{kg}^{-1}$ at $334 \mathrm{~m}$ depth to a maximum of $0.42 \mathrm{nmol} \mathrm{kg}^{-1}$ at $865 \mathrm{~m}$, with concentrations $\sim 0.35 \mathrm{nmol} \mathrm{kg}^{-1}$ below $1,000 \mathrm{~m}$ depth. A total of $22 \mathrm{Cd} / \mathrm{Ca}$ measurements were made on $H$. elegans from the LGM sections of six cores, from 303 to $1,200 \mathrm{~m}$ palaeodepth $(120 \mathrm{~m}$ was subtracted from the present core depths to account for the glacial sea level drop $)^{21}$. Below $600 \mathrm{~m}, \mathrm{LGM} \mathrm{Cd}_{\mathrm{W}}$ averaged $0.18 \mathrm{nmol} \mathrm{kg}^{-1}$, or $\sim 0.1-0.2 \mathrm{nmol} \mathrm{kg}^{-1}$ lower than today, a reduction of $40-60 \%$ (Fig. 1). Application of the modern global $\mathrm{Cd}: \mathrm{P}$ relationship ${ }^{16.18}$ to our data gives $\mathrm{PO}_{4}^{3-}$ concentrations (below $600 \mathrm{~m}$ ) of $1.5-$ I. $6 \mu \mathrm{mol} \mathrm{kg}$. during the late Holocene and $0.8-0.9 \mu \mathrm{mol} \mathrm{kg}$ during the LGM, for changes of $0.6-0.8 \mu \mathrm{mol} \mathrm{kg}{ }^{-1}$. These results are in good agreement with the marked LGM $\delta^{13} \mathrm{C}$ increase and implied $0.4-0.9 \mu \mathrm{mol} \mathrm{kg}^{-1} \mathrm{PO}_{4}^{3-}$ decrease seen previously $y^{11,12}$. Although these $\mathrm{PO}_{4}^{3-}$ estimates are subject to some error, arising in part from regional scatter in the global Cd:P relationship ${ }^{2}$, the magnitude of the inferred LGM-Holocene shift is a reasonable approximation. The concordance between $\mathrm{Cd}$ and $\delta^{13} \mathrm{C}$ suggests that there was little or no difference in the air-sea component of Bahamian $\delta^{13} \mathrm{C}\left(\delta^{13} \mathrm{C}_{25}\right)$ between the LGM and today, although airsea exchange effects may influence the $\delta^{13} \mathrm{C}$ record on shorter timescales.

Three main processes could have reduced nutrients in the Bahama banks glacial thermodine: (1) the disappearance of highnutrient Antarctic Intermediate Water (AAIW), (2) decreased productivity in gyre surface waters, and (3) decreased transit times from where isopycnals outcropped. AAIW contributes $<5 \%$ of Bahamian lower thermocline waters today ${ }^{33}$, so its complete removal would account for $<10 \%$ of the giacial nutrient decrease. If modern circulation rates were maintained and if glacial North Atlantic preformed $\mathrm{PO}_{4}^{3-}$ values were no lower than today, an unrealistically large $(\sim 80 \%)$ glacial reduction in productivity would be required to explain the low Bahamian $\mathrm{PO}_{4}^{3-}$ levels. We therefore conclude that LGM subtropical gyre waters had much shorter transit times from where isopycnals outcropped ${ }^{16,12}$, primarily due to stronger winds, a southward shift of thermocline outcrop areas ${ }^{24}$, and a decreased contribution from the poorly 
ventilated subpolar gyre. The existence of a faster, nutrient-depleted gyre is consistent with the 'nutrient deepening' mechanism for lowering atmospheric $\mathrm{CO}_{2}$ leveis ${ }^{25}$.

As waters below the modern Bahamian nutrient maximum are not strongly influenced by wind-driven circulation, their glacial nutrient reduction is best explained by changes in deep-water formation. During the LGM, formation of NADW was substantially reduced ${ }^{1,2}$, being replaced by the shallower $(<2,500 \mathrm{~m})$ low-nutrient Glacial North Atlantic Intermediate Water (GNAIW) ${ }^{3-5}$. At $1,800 \mathrm{~m}$ in the Caribbean, GNAIW had a $\mathrm{Cd}_{\mathrm{W}}$ of $0.21 \mathrm{nmol} \mathrm{kg}^{-1}$ (ref. 20), about the same as the glacial $C d_{W}$ estimate at $1,200 \mathrm{~m}$ in the
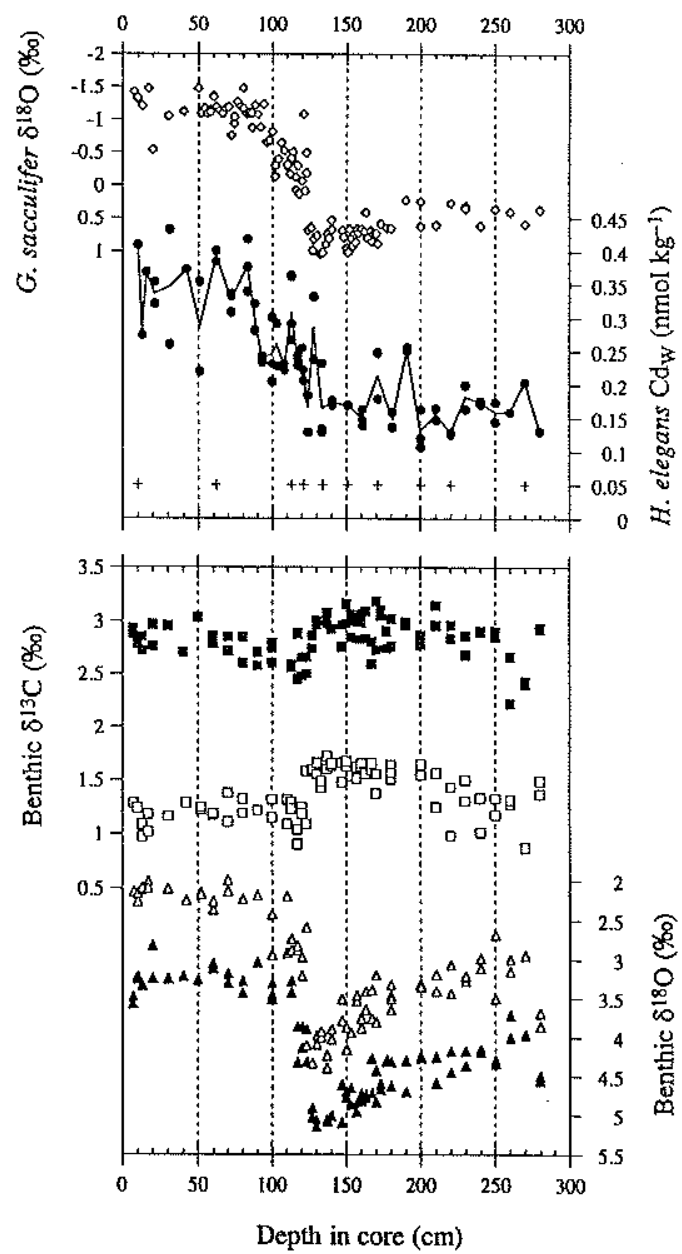

Figure 2 Data from core $0 \mathrm{C} 205-2-103 \mathrm{GGC}\left(26^{\circ} 04^{\prime} \mathrm{N}, 78^{\circ} 03^{\prime} \mathrm{W} ; 965 \mathrm{~m}\right)$. Shown are records of planktonic $\delta^{18} \mathrm{O}$ (Giobigerinoides sacculfer, open diamonds), benthic $\mathrm{Cd}_{w}\left(H\right.$, elegans, filled circies), benthic $\delta^{13} \mathrm{C}(H$. elegans, filled squares; Cibicidoides kullenbergi, open squares), and benthic $\delta^{\mathrm{iB}} \mathrm{O}(\mathrm{H}$. elegans, filled triangles; $C$. kullenbergi, open triangles). Crosses indicate the depths of accelerator mass spectrometer (AMS) radiocarbon dates (see Supplementary Information). Most of the $C$. Kullenbergi isotopic data have been presented previously ${ }^{12}$. The large isotopic offsets between $H$. elegans and $C$. kuflenbergi are due to their different mineralogies. Benthic isotopes were measured on single shells, whereas planktonic ${ }^{18} \mathrm{O}$ and benthic $C d_{w}$ used mulliple $(-3-15)$ shells per analysis. Of the $79 \mathrm{Cd}$ measurements, three were considered to be signiticantly contaminated ( $\mathrm{Cd} d_{w}$ much higher than expected) and were omitted.
Bahamas $\left(0.19 \pm 0.02 \mathrm{nmol}^{-1}\right)$. Although it is difficult to make any clear distinction between the lower gyre and upper deep water, it is likely that the core from $965 \mathrm{~m}$ (OC205-2-103GGC) was at least partially influenced by the deep water. A high-resolution record of $H$. elegans $\mathrm{Cd}_{\mathrm{W}}$ from this radiocarbon-dated core chronicles the transition from marine isotope stage 3, through the LGM, to the present (Fig. 2; sec Supplementary Information for dates). Concentrations of $\mathrm{Cd}_{\mathrm{w}}$ were relatively low during stages 3 and 2, averaging $0.17 \mathrm{nmol} \mathrm{kg}^{-1}$. The deglaciation is characterized by a general increase between $\sim 19,500$ and 8,500 calendar years before present ( $\mathrm{cal} . \mathrm{yr} \mathrm{BP}$ ), with Holocene concentrations averaging $0.35 \mathrm{nmol} \mathrm{kg}$. Within this rise is a period of decreased $\mathrm{Cd}_{w}$ coincident with the Younger Dryas interval. Comparison to a high-resolution Cd record from the deep North Atlantic $(4,450 \mathrm{~m}$, Bermuda rise) ${ }^{3,9}$ reveals a striking inverse correlation (Fig. 3). This suggests that at times of weak NADW formation (high $\mathrm{Cd}_{w}$ at $4,450 \mathrm{~m}$ ), GNAIW formation was strong (low $\mathrm{Cd}_{\mathrm{W}}$ at $965 \mathrm{~m}$ ), Another potential source of nutrient-depleted intermediate waters, Mediterranean Outflow Water, does not appear to have strengthened during either the Younger Dryas ${ }^{6}$ or the LGM ${ }^{26}$. We

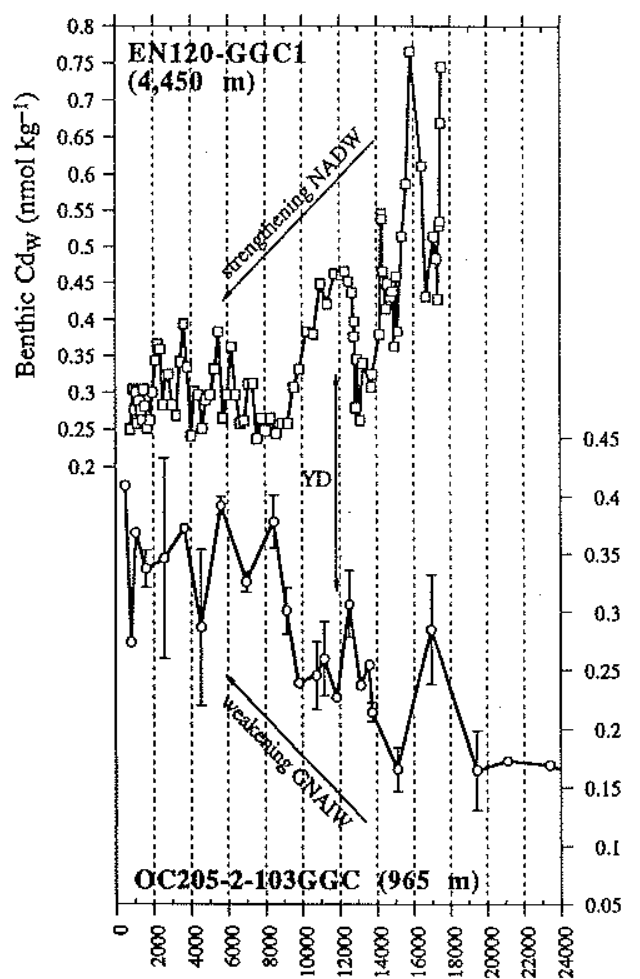

NATUREIVOL 393111 JUNE 1998 


\section{letters to nature}

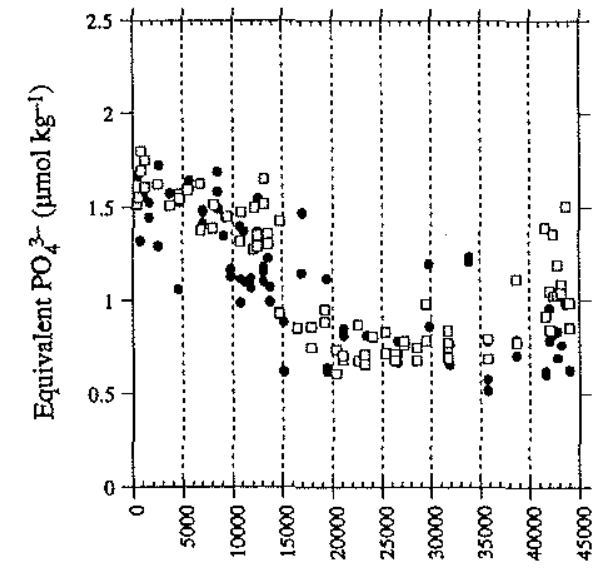

Calendar age (yr BP)

Figure 4 Estimated seawater $\mathrm{PO}_{4}^{3}$ concentrations recorded in core $0 \mathrm{C} 205-2$ 103GGC. Estimates are based on $H$. elegans $C d_{w}$ (filled circles) and $C . k$ kultenbergi $8^{13} \mathrm{C}$ (open squares). $C d_{w}$ was converted using the global Cd:P relationship: $\mathrm{PO}_{4}^{3-}=4.81 \mathrm{Cd}_{\mathrm{w}}$ for $\mathrm{Cd}_{\mathrm{w}}<0.28 \mathrm{nmolkg} "$ " , and $\mathrm{PO}_{4}^{3-}=0.638+2.51 \mathrm{Cd}_{\mathrm{w}}$ lor $C d_{\mathrm{W}}>0.28 \mathrm{nmolkg}^{-1}$ (refs 16, 18). Although it has been suggested that the LGM ocean contained perhaps $13 \%$ less dissolved Cd than today, such a decrease is nol well enough constained to warrant the use of different equations for the glacial data ${ }^{20,27}$. For data $\leqslant 5,000 \mathrm{yr} B ;, \delta^{13} \mathrm{C}$ was converted using the modern equation, $\mathrm{PO}_{4}^{3-}=2.45-\left[0.91\left(\delta^{13} \mathrm{C}-\delta^{13} \mathrm{C}_{a s}\right)\right]$ (rel. 27). The giacial equation $\mathrm{PO}_{4}^{3-}=2.16-\left[1.05\left(\delta^{13} \mathrm{C}-\delta^{13} \mathrm{C}_{\text {as }}\right)\right]$ (ref. 27). which accounts for the glacial whole-ocean isotopic shift 4.5 , was used for data $\geqslant 20,000 \mathrm{yr}$ ar. Intermediate equations that evolve linearly with time were used between 5.000 and $20,000 y r$ pe. Based on $\delta^{13} \mathrm{C}$ and $\mathrm{Cd}_{W}$ from the cores presented in Fig. $1, \delta^{13} \mathrm{C}_{a s}$ was taken to be $0.25 \%$. This $\delta^{13} \mathrm{C}_{a s}$ may also contain some foraminiferal disequilibrium ("vital") effects.

therefore present what is, to our knowledge, the first direct palaeonutrient evidence for GNAIW formation during the Younger Dryas, at the expense of NADW.

The raw benthic $\delta^{13} \mathrm{C}$ record from 103GGC looks significantly different from the $\mathrm{Cd}$ record (Fig. 2). Converting all $\delta^{13} \mathrm{C}$ and $\mathrm{Cd}$ to equivalent $\mathrm{PO}_{4}^{3-}$ (refs 16, 18, 27), and accounting for the wholeocean glacial carbon isotopic shift of $0.3 \%$ (refs 4,5 ), again produces reasonably good agreement during the Late Holocene and LGM (Fig. 4). Although it is difficult to estimate how the wholeocean $\delta^{13} \mathrm{C}$ shift evolved across the deglaciation, a gradual linear change removes the $\delta^{13} \mathrm{C}$ minimum seen at $\sim 13,000$ cal. $y r$ gp improving the $\mathrm{Cd}-\delta^{13} \mathrm{C}$ agreement. Discrepancies remain, however during the Younger Dryas and during stage 3 (before 40,000 cal. yr Bp). These may be attributed to the obscuring effects of the whole-ocean isotopic shift and to the influences of air-sea exchange on $\delta^{13} \mathrm{C}$ (ref. 19). For example, the opposing air-sea isotopic effects of cooling (raising $\delta^{13} \mathrm{C}$ ) and decreased air-sea contact time (lowering $\delta^{13} \mathrm{C}$ ) may have been roughly balanced during the LGM, but decreased air-sea contact may have dominated over the less extreme coolings of the Younger Dryas and stage 3. Given such complications to the $\delta^{13} \mathrm{C}$ record, we believe that $\mathrm{Cd}$ is a more reliable indicator of short-term nutrient changes, especially within the main climate transitions.

Our results demonstrate that periods of eninanced intermediatewater production alternate with periods of enhanced deep-water formation on both orbital and millennial timescales. Analogous dynamics operate in the modern North Atlantic on much shorter (decadal) timescales, with deep convection alternating between regions of upper (Labrador Sea) and lower (Greenland Sca) NADW formation ${ }^{23}$. However, these brief reconfigurations have smaller effects on oceanic temperature and nutrient structure than the larger-scale events occurring during the last deglaciation.

The cooling of the North Atlantic during the Younger Dryas las long been linked to a reduction or cessation of NADW formation, which today releases a great deal of heat to the high-fatitude atmosphere ${ }^{3,7-9}$. Recent modelling suggests that a peak in atmospheric radiocarbon activity during the Younger Dryas is best explained by a cessation of NADW and a subsequent increase in GNAIW formation ${ }^{29}$. Our Cd data from $965 \mathrm{~m}$ indeed indicate that GNAIW partially replaced NADW during this cold period, though to a lesser extent than during the LGM. A Younger Dryas $\delta^{13} \mathrm{C}$ section through the eastern Atlantic ${ }^{6}$ supports this view of a moderately weakened NADW, but there are too few well-positioned shallow data in that reconstruction to discern a clear GNAIW mass; GNAIW should also be less evident in the eastern North Atlantic because deep waters are concentrated into western boundary currents. The Younger Dryas cooling may have thus been accomplished through the formation of intermediate waters that were less efficient at heating the North Atlantic than NADW ${ }^{30}$. It is clear that North Atlantic climate change at the end of the last glacial period can no longer by explained by a simple convection 'on/off' switch.

Received 22 July 1997; accepted I April 1998

1. Bopic, E. A. \& Keigwin, L. D. Deep circulation of ulte North Atlantic ower the last 200,000 yeass Geochenical evidence. Science

2. Curry, W. B. \& Lohmann, G.P. Reduced advection into Atlantic Occan decp eastern hasins during las glaciation maximum. Nafure 306, 577-580 (1983).

. Boyle. E. A. \& Xeigwin, L.. D. North Alanatic thermohaline circulation during the past 20,050 years linked to high-lalitude surface temperature. Nature 330, 35-40 f(1987)

4. Curry, W. B., Duplessy, J. C., Labcyric, L.. D) \& Shackleton, N. I. Chagkes in the distribution of ${ }^{\text {fl }} \mathrm{C}$ of deep water $2 \mathrm{CO}$; belween the last glaciation and the Holocenc, Palkewizanography 3, 317-341 (1988). 5. Duplessy. I. C. at al. Deepwater source variations during the last climatic cycte and their inglact on the givbal deepwater circulation. Pateoceartography' 3, 343-360 (1988)

Sarrutitiein, M. ef al. Changes in easi Allantic decpwater circuition over the last 30,090 years: Eight time slice reconstructions. Palecceantograplyy $9,209-267$ (1994)

Bruceker, W. S., Peteet, D. M. \& Rind, D. Does the oceak-atmosphere susiem lave more than one stable mode of opera tion

kioecker, W. S. et at. The chronalogy of the last itg laciation: Impkicatiens to the cause of the Younger

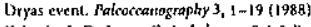

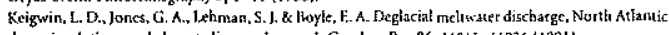
deep circutation, and abrups climate change. I. Geophyss. Res. 96. 16811 - I6R26 (1991).

A Allartic dis

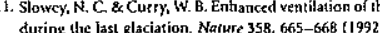

during the last placiation. Nature 358, 665-668 (1992). . Stowey, N. C. \& Curry, W. B. Glacial-interglacial diflerences in circulation
the upper western North Altantic, Palkocentograply 10, $715-732$ (1995)

13. Haddad G. A. \& Droxker, A W. Metastabic CaCO, dissolution al intermediste water depths of the Caribbean and western North Aliantic: Implications for intermediate walet circulation during the past 200,000 years. Paleoceanography $11,701-716(1996)$.

14. Pedlosky, ). The dynamics of the oceanic stibtropical gyres. Scieitce 248, 316-322 (1990).

15. Otson, D. B. Schott, F, A., Zantopp. R J. \& I leaman, K. D. The mean citculation east of the Bahamas as determined from a recent measurement program and tristorical XBT data. J. Phys. Ocennogr. 14. $1470-1487(1984)$.

16. Boyis, E. A. Cadmiun: Chemical tracer of decpwalter palenceanography, Palcoccuttographiy 3, 471-489 (I988)

17. Hester, K. \& Boyle, E. A. Water chemistry control of the Cd content of benthic foraminifeta. Nature 298, 260-261 (1982).

B. Boylc, E. A., labeyrie, L \& Duplessy, I. C. Cakitic forminiferal data confirmed by cadmium in aragonitic Hoeghturditas Application to the last glacial maximuas in the nerthern Indian Ocean. Patencentrograpily 10, 881-900 (is95).

19. Charles, C. D. Wright, I. D. \& Fairtianks, R. G. Thernodynamic intheruces on the inarine carbon isotope record. Paleoceanograpiy 8, 691-697 (1993)

20. Boyle, E. A. Cadimium and sis C palcochemical cxeal distributions during ulte Stage 2 glacial maximum. Atmu. Rev. Earth Planet. Sri. 20, 245-287 (1992).

Fairbanks, R. G. A 12,000-year glacio-eusstatic sea level record: influence of glacial meting rates on the Younget Dryas event and decp-ocean circutation. Natise 342, 637-642 (1989). Change (eds Zahn, R. ef at) 195-221 (NATO ASI Ser. Vol. I 17, Ikellin, 1994).

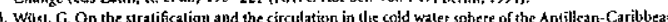
basins. Deep-Sea Res. 10, 165-187 (1963).

24. CLIMAP Proiect Members. The surface of the ice-age Earth. Science 191, 1131-1137 (1976) 25. Boyle, E. A. The role of vertical chemical fractionation in tontrolling Late Quaternary atthosphetic carbon dioxide. f. Geophys. Res. 93, 15701 - 15714 (1988)

26. Zahn, R. el al. Thermohaline instability in the Nurth Allantic during meliwater events: Stable isotope and ice-rafted detritus eccords fron core 5075-26KI., Porluguese margin. Paleocethugraphy 12, 6\%6710 (1997)

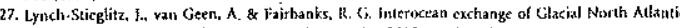

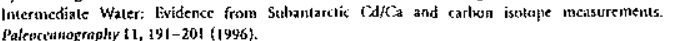

- NATUREIVOI 393III IUNE 199 
letters to nature

28. Dickson, R., Lazier, I., Mecincke f., Rhines, P. \& Swift, I. Long.tern cootdinated changes in the 28. Dickson, R., tazier, l.. Meincke, I.. Rhines, L. \& Swift, I. Long.tern cootdif

29. Huective activity or

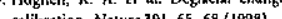

Rahmstorf, S. Rapid dimate transitions in a coupied ocean-almosphete model. Nature 372, 82-85

1994).

Supplementary Information is available on Naturés World-Wide Web site (hetp://www.sialure.com) or as paper copy from the jondon editorial office of Nature.

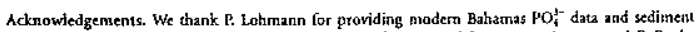

grab samples; $M$. Jeglinski, D. Ostermann and L. Zou for isotope laboralory assistance; and $\mathrm{E}$. Boyle

was stupported by the US NSE

Correspondence and requests for materials should be addressed to T.M.M. (e-mail: Imarclitio@whoi

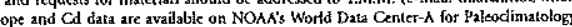

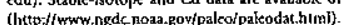

NATUREIVOL 393:H JUNE 1998 
Supplementary Information for "Millennial-scale changes in North Atlantic circulation since the last glaciation" by Marchitto et al. (Nature 393, 557-561, 1998).

Radiocarbon and calibrated ages of $G$. sacculifer samples from core OC205-2-103GGC

\begin{tabular}{ccccc}
\hline $\begin{array}{c}\text { Depth in core } \\
(\mathrm{cm})\end{array}$ & $\begin{array}{c}\text { Radiocarbon age } \\
\text { (yr BP) }\end{array}$ & $\begin{array}{c}\text { Calibrated age } \\
\text { (yr BP) }\end{array}$ & $\begin{array}{c}\text { NOSAMS } \\
\text { Accession \# }\end{array}$ & $\begin{array}{c}\text { G. sacculifer } \\
\text { abundance (\#/g) }\end{array}$ \\
\hline 10 & $920 \pm 35$ & 510 & OS-10523 & $29 \pm 4$ \\
62 & $5,290 \pm 45$ & 5,640 & OS-10524 & $94 \pm 10$ \\
113 & $11,000 \pm 50$ & 12,530 & OS-10526 & $54 \pm 8$ \\
121 & $12,200 \pm 55$ & 13,760 & OS-10525 & $31 \pm 4$ \\
134 & $17,100 \pm 100$ & 19,680 & OS-10527 & $8 \pm 2$ \\
151 & $20,200 \pm 85$ & 23,420 & OS-10528 & $18 \pm 3$ \\
171 & $25,900 \pm 120$ & 29,830 & OS-10529 & $26 \pm 5$ \\
200 & $31,500 \pm 170$ & 35,760 & OS-10530 & $47 \pm 8$ \\
220 & $37,400 \pm 360$ & 41,610 & OS-10645 & $75 \pm 12$ \\
270 & $39,500 \pm 480$ & 43,600 & OS-10531 & $25 \pm 4$ \\
\hline
\end{tabular}

All radiocarbon measurements were performed at the National Ocean Sciences AMS (NOSAMS) Facility at WHOI. Radiocarbon ages are not reservoir-corrected; calibrated (calendar) ages assume a $400 \mathrm{yr}$ reservoir age. Radiocarbon ages younger than $18,760 \mathrm{yr}$ BP were converted to calibrated ages using a marine calibration based on dendrochronological and coral data 1 . Older radiocarbon ages were converted using the coral-derived equation $\mathrm{C}=-1807+1.39 \mathrm{R}-\left(5.85 \times 10^{-6}\right) \mathrm{R}^{2}$, where $\mathrm{C}$ is calibrated age and $\mathrm{R}$ is reservoir-corrected radiocarbon age ${ }^{2}$. G. sacculifer abundances are given as the number of $>300 \mu \mathrm{m}$ individuals per $\mathrm{g}$ of dry bulk sediment.

\section{References}

1. Stuiver, M. \& Reimer, P. J. Extended ${ }^{14} \mathrm{C}$ data base and revised Calib $3.0{ }^{14} \mathrm{C}$ age calibration program. Radiocarbon 35, 215-230 (1993).

2. Bard, E., Arnold, M. \& Hamelin, B. Present status of the radiocarbon calibration for the Late Pleistocene. GEOMAR Rept. 15, 52-53 (1992).

Stable isotope and $\mathrm{Cd}$ data are available on NOAA's World Data Center-A for Paleoclimatology (http://www.ngdc.noaa.gov/paleo/paleodat.html). 


\section{Additional results from core OC205-2-103GGC}

This section briefly summarizes planktonic foraminiferal radiocarbon and benthic foraminiferal $\mathrm{Cd} / \mathrm{Ca}, \delta^{13} \mathrm{C}$, and $\delta^{18} \mathrm{O}$ results obtained from Bahama Banks core OC205-2103GGC since the publication of Marchitto et al. (1998). Further discussion of these data can be found in Curry et al. (in press).

\section{Revised chronology}

The deepest $(270 \mathrm{~cm}) G$. sacculifer radiocarbon measurement reported in Marchitto et al. (1998) suggested an unusually abrupt increase in sedimentation rate between 220 and $270 \mathrm{~cm}\left(\sim 25 \mathrm{~cm} \mathrm{kyr}^{-1}\right)$ relative to the interval between 113 and $220 \mathrm{~cm}$ ( $\sim 4 \mathrm{~cm} \mathrm{kyr}^{-1}$; Figure 1.1). Two new measurements at 240 and $267 \mathrm{~cm}$ (Figure 1.1, Table 1.1) give more reasonable sedimentation rates $\left(\sim 10\right.$ and $6 \mathrm{~cm} \mathrm{kyr}^{-1}$, respectively), and suggest that the $270 \mathrm{~cm}$ sample is anomalously young. The $270 \mathrm{~cm}$ measurement is therefore excluded from the revised chronology. This correction extends the age of the core's base from $\sim 44,000$ to $\sim 52,000$ cal yr BP, encompassing most of marine isotope stage (MIS) 3, probably through interstadial 14 (Grootes and Stuiver, 1997).

A third new radiocarbon measurement at $88 \mathrm{~cm}$ has also been added (Figure 1.1, Table 1.1), increasing the apparent duration of the Younger Dryas $\mathrm{Cd} / \mathrm{Ca}$ event by $\sim 1,000$ cal yr. It is clear that the duration of this event greatly exceeds the length of the Younger Dryas itself (Grootes and Stuiver, 1997). In other words, the modern circulation was not established until well into the Holocene $(\sim 8,000$ cal yr BP); a similar conclusion may be drawn from core EN120-GGC1 (Boyle and Keigwin, 1987; Keigwin et al., 1991). It is further possible that intermediate-depth ventilation was reduced at the start of the Younger Dryas, with GNAIW formation strengthening several hundred years later. This was alluded to in Marchitto et al. (1998) by noting that the record is consistent with the radiocarbon modeling of Hughen et al. (1998), who proposed a temporary shutdown of both NADW and GNAIW formation. A higher sedimentation rate core is required to truly resolve such short-term events. 


\section{Benthic $\mathrm{Cd} / \mathrm{Ca}$ and stable isotopes}

Gaps in the benthic foraminiferal records of Marchitto et al. (1998) have been filled by 45 new H. elegans $\mathrm{Cd} / \mathrm{Ca}$ measurements and 167 new C. kullenbergi $\delta^{13} \mathrm{C}$ and $\delta^{18} \mathrm{O}$ measurements (Figure 1.2 ; Tables $1.2,1.3$ ). The new data are generally very consistent with the earlier data, and reveal a series of low-amplitude, millennial-scale fluctuations. Figure 1.3 is a revised version of Marchitto et al.'s (1998) Figure 4, where the $\mathrm{Cd} / \mathrm{Ca}$ and $\delta^{13} \mathrm{C}$ records are directly compared by converting each measurement to equivalent $\mathrm{PO}_{4}{ }^{3-}$. Data calculated using the modern ${ }^{13} \mathrm{C}: \mathrm{PO}_{4}{ }^{3-}$ relationship (LynchStieglitz et al., 1996) are plotted as squares, and data calculated using the LGM relationship (which accounts for a $2 \%$ increase in organic matter $\delta^{13} \mathrm{C}$ and a $0.3 \%$ decrease in mean ocean inorganic $\delta^{13} \mathrm{C}$; Lynch-Stieglitz et al., 1996) are plotted as diamonds. Marchitto et al. (1998) held $\delta^{13} \mathrm{C}_{\text {as }}$ constant at $0.25 \%$, a value that produced reasonable agreement between $\mathrm{Cd} / \mathrm{Ca}$ and $\delta^{13} \mathrm{C}$ during both the Holocene and the LGM. The new data suggest that $0.15 \%$ is a better approximation for a constant $\delta^{13} C_{a s}$ value. Both values are consistent with estimates based on benthic foraminifera from Bahama Banks core tops below $500 \mathrm{~m}$ water depth $(0.15-0.51 \%)$.

The assumption of constant $\delta^{13} \mathrm{C}_{\text {as }}$ results in good agreement between $\mathrm{Cd} / \mathrm{Ca}$ and $\delta^{13} \mathrm{C}$ during the Holocene (using the modern ${ }^{13} \mathrm{C}^{13} \mathrm{PO}_{4}{ }^{3-}$ equation) and during most of MIS 2 and 3 (using the LGM equation). The two tracers may even be consistent during the Younger Dryas if the LGM equation is applicable for that time. It is likely that the LGM equation is at least partly applicable to the Younger Dryas, since mean ocean $\delta^{13} \mathrm{C}$ probably did not reach Holocene levels until after 10,000 cal yr BP (Shackleton et al., 1983). Both $\mathrm{Cd} / \mathrm{Ca}$ and $\delta^{13} \mathrm{C}$ show a nutrient peak between $\sim 30,000$ and $35,000 \mathrm{cal} \mathrm{yr}$ $\mathrm{BP}$, and a general rise between $\sim 30,000$ and $45,000 \mathrm{cal} \mathrm{yr}$ BP. Both features are associated with decreased benthic $\delta^{18} \mathrm{O}$ values (Figure 1.2), suggesting slightly warmer, more nutrient-rich waters near the base of the thermocline at these times. These conditions probably reflect a slightly reduced influence of GNAIW, and may correlate with warm air 
temperatures over Greenland, specifically interstadials 5 through 12 (Grootes and Stuiver, 1997; Curry et al., in press). The only interval when $\mathrm{Cd} / \mathrm{Ca}$ and $\delta^{13} \mathrm{C}$ significantly disagree is between $\sim 45,000$ cal yr BP and the base of the core ( interstadial 14; Grootes and Stuiver, 1997). This decoupling can be explained by decreased $\delta^{13} C_{a s}$ values, perhaps due to air-sea exchange at warmer temperatures. Finally, several low $\delta^{13} \mathrm{C}$ values during the Holocene imply brief episodes of nutrient enrichment. The absence of these features in the $\mathrm{Cd} / \mathrm{Ca}$ record may simply be due to the reduced temporal resolution of a given $\mathrm{Cd} / \mathrm{Ca}$ measurement, which is the average of $\sim 3$ to 30 individual foraminifera (versus a single individual for $\delta^{13} \mathrm{C}$ ). However, it is also possible that these single individuals' low $\delta^{13} \mathrm{C}$ values were affected by factors other than bottom water $\delta^{13} \mathrm{C}$, such as high organic carbon fluxes during spring bloom-type events (McCorkle et al., 1999).

\section{Conclusions}

New benthic $\mathrm{Cd} / \mathrm{Ca}, \delta^{13} \mathrm{C}$, and $\delta^{18} \mathrm{O}$ measurements reveal low-amplitude, millennial-scale variability in the apparent nutrient content and temperature of bottom waters above core OC205-2-103GGC. These new observations do not alter the conclusions of Marchitto et al. (1998). The uncertainty involved in converting $\delta^{13} \mathrm{C}$ to equivalent $\mathrm{PO}_{4}^{3-}$ (due to uncertainties in the temporal evolution of mean ocean DIC $\delta^{13} \mathrm{C}$, organic matter $\delta^{13} \mathrm{C}$, and regional $\delta^{13} \mathrm{C}_{\text {as }}$ ) continues to suggest that $\mathrm{Cd} / \mathrm{Ca}$ is a better proxy for nutrient content at the Bahama Banks. 


\section{References}

Boyle, E. A., and L. D. Keigwin, North Atlantic thermohaline circulation during the last 20,000 years linked to high latitude surface temperature, Nature, 330, 35-40, 1987.

Curry, W. B., T. M. Marchitto, J. F. McManus, D. W. Oppo, and K. L. Laarkamp, Millennial-scale changes in ventilation of the thermocline, intermediate, and deep waters of the glacial North Atlantic, in Mechanisms of Millennial-Scale Global Climate Change, edited by P. U. Clark and R. S. Webb, AGU Monograph, in press.

Grootes, P. M., and M. Stuiver, Oxygen 18/16 variability in Greenland snow and ice with $10^{3}$ to $10^{5}$-year time resolution, J. Geophys. Res., 102, 26455-26470, 1997.

Hughen, K. A., et al., Deglacial changes in oceanic circulation from an extended radiocarbon calibration, Nature, 391, 65-68, 1998.

Keigwin, L. D., G. A. Jones, S. J. Lehman, and E. A. Boyle, Deglacial meltwater discharge, North Atlantic deep circulation, and abrupt climate change, J. Geophys. Res., 96, 16811-16826, 1991.

Lynch-Stieglitz, J., A. van Geen, and R. G. Fairbanks, Interocean exchange of Glacial North Atlantic Intermediate Water: Evidence from Subantarctic $\mathrm{Cd} / \mathrm{Ca}$ and carbon isotope measurements, Paleoceanography, 11, 191-201, 1996.

Marchitto, T. M., W. B. Curry, and D. W. Oppo, Millennial-scale changes in North Atlantic circulation since the last glaciation, Nature, 393, 557-561, 1998.

McCorkle, D. M., P. A. Martin, B. H. Corliss, D. W. Lea, J. McManus, and G. P. Klinkhammer, Calibration studies of benthic foraminiferal isotopic and elemental composition, Eos, Transactions, $A G U, 80, \mathrm{~S} 172,1999$.

Shackleton, N. J., J. Imbrie, and M. A. Hall, Oxygen and carbon isotope record of East Pacific core V19-30: implications for the formation of deep water in the late Pleistocene North Atlantic, Earth Plan. Sci. Lett., 65, 233-244, 1983.

Slowey, N. C., and W. B. Curry, Glacial-interglacial differences in circulation and carbon cycling within the upper western North Atlantic, Paleoceanography, 10, 715-732, 1995. 


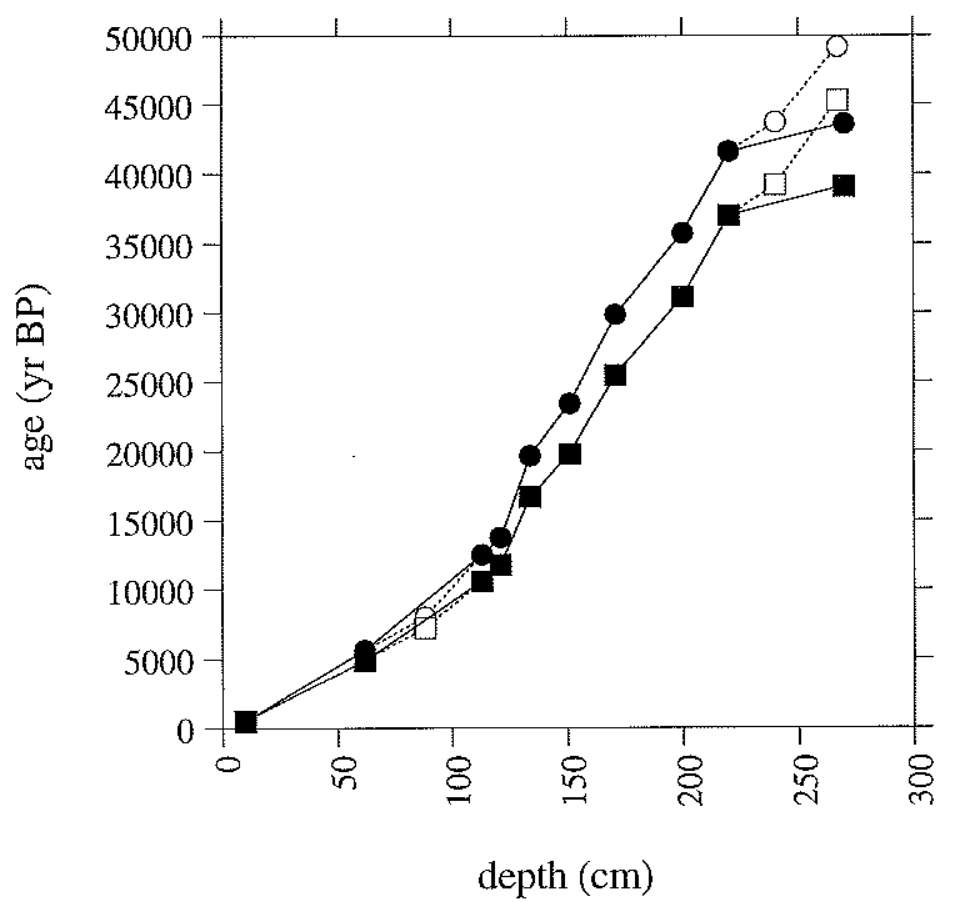

Figure 1.1. Reservoir-corrected radiocarbon ages (squares) and calibrated ages (circles) vs. depth in core OC205-2-103GGC. Original dates from Marchitto et al. (1998) are filled, and new dates are open. The deepest $(270 \mathrm{~cm})$ date is excluded from the new age model. 

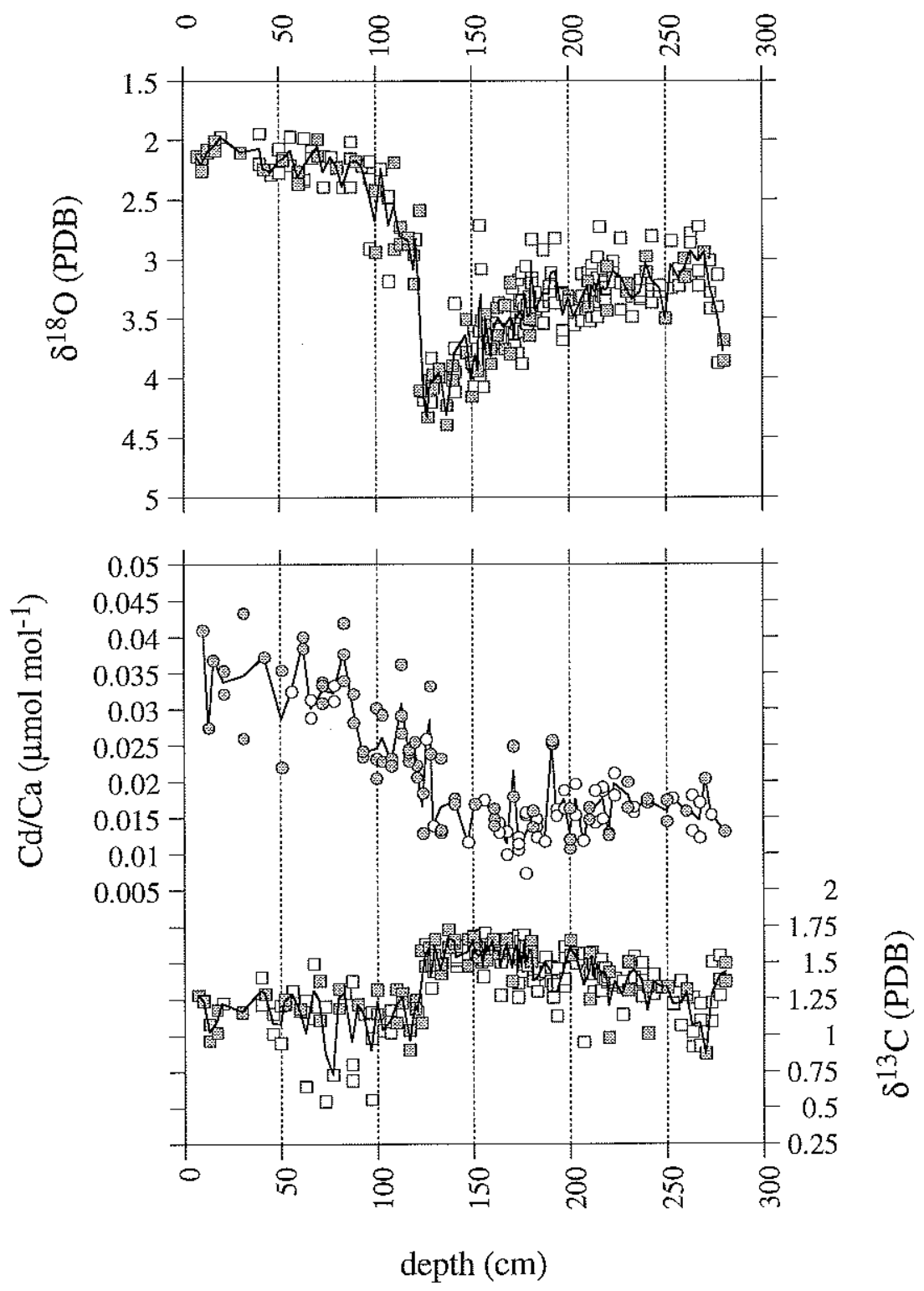

Figure 1.2. Complete records of C. kullenbergi $\delta^{18} \mathrm{O}$ and $\delta^{13} \mathrm{C}$ (squares) and $H$. elegans $\mathrm{Cd} / \mathrm{Ca}$ (circles) in core OC205-2-103GGC. Data from Marchitto et al. (1998) are shaded, and new data are open. 


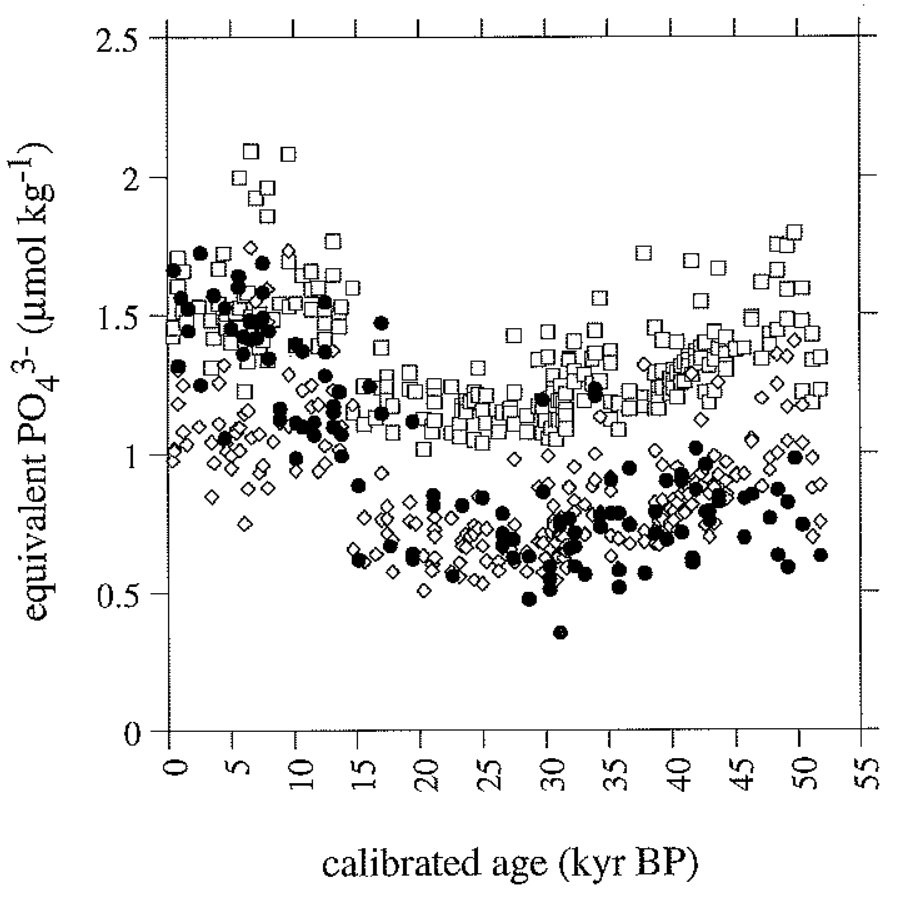

Figure 1.3. Estimated seawater $\mathrm{PO}_{4}{ }^{3-}$ concentrations recorded by H. elegans $\mathrm{Cd} / \mathrm{Ca}$ (filled circles) and C. kullenbergi $\delta^{13} \mathrm{C}$ (open symbols) in core OC205-2-103GGC. $\delta^{13} \mathrm{C}$ was converted using both the Holocene (squares) and LGM (diamonds) $\delta^{13} \mathrm{C}_{\mathrm{PO}}{ }^{3-}$ equations of Lynch-Stieglitz et al. (1996). Both equations were applied assuming a constant $\delta^{13} \mathrm{C}_{\text {as }}$ of 0.15 per mil. 
Table 1.1. New radiocarbon and calibrated ages of G. sacculifer from core OC205-2103GGC

\begin{tabular}{|c|c|c|c|}
\hline $\begin{array}{l}\text { depth } \\
(\mathrm{cm})\end{array}$ & $\begin{array}{l}\text { radiocarbon age } \\
\text { (yr BP) }\end{array}$ & $\begin{array}{l}\text { calibrated age } \\
(\mathrm{yr} \mathrm{BP})\end{array}$ & $\begin{array}{l}\text { NOSAMS } \\
\text { accession \# }\end{array}$ \\
\hline $\begin{array}{l}88 \\
240 \\
267\end{array}$ & $\begin{array}{l}7,630 \pm 45 \\
39,600 \pm 390 \\
45,700 \pm 500\end{array}$ & $\begin{array}{l}8,020 \\
43,700 \\
49,200\end{array}$ & $\begin{array}{l}\text { OS- } 15376 \\
\text { OS-15377 } \\
\text { OS-15378 }\end{array}$ \\
\hline
\end{tabular}


Table 1.2. All $H$. elegans $\mathrm{Cd} / \mathrm{Ca}$ measurements from core OC205-2-103GGC

\begin{tabular}{|c|c|c|c|c|c|c|}
\hline \multirow{2}{*}{$\begin{array}{l}\text { depth } \\
(\mathrm{cm})\end{array}$} & \multirow{2}{*}{$\begin{array}{l}\begin{array}{l}\text { cal age } \\
(\mathrm{kyr} B P)\end{array} \\
0.51\end{array}$} & \multicolumn{4}{|c|}{$\begin{array}{l}\mathrm{Cd} / \mathrm{Ca} \\
(\mu \mathrm{mol} \mathrm{mol}-1)\end{array}$} & \multirow{2}{*}{$\begin{array}{l}\begin{array}{l}\text { mean } \pm \text { std dev } \\
\left(\mu \mathrm{mol} \mathrm{mol} \mathrm{f}^{-1}\right)\end{array} \\
0.041\end{array}$} \\
\hline & & 0.041 & & & & \\
\hline 13 & 0.81 & 0.027 & & & & 0.027 \\
\hline 15.5 & 1.05 & 0.037 & & & & 0.037 \\
\hline 21 & 1.60 & 0.032 & 0.035 & & & $0.034 \pm 0.002$ \\
\hline 31 & 2.58 & 0.043 & 0.026 & & & $0.035 \pm 0.012$ \\
\hline 42 & 3.67 & 0.037 & & & & 0.037 \\
\hline 51 & 4.55 & 0.022 & 0.035 & & & $0.029 \pm 0.009$ \\
\hline 56 & 5.05 & 0.032 & & & & 0.032 \\
\hline 62 & 5.64 & 0.040 & 0.038 & & & $0.039 \pm 0.001$ \\
\hline 66 & 6.01 & 0.029 & 0.031 & & & $0.030 \pm 0.002$ \\
\hline 72 & 6.56 & 0.031 & 0.033 & 0.034 & & $0.033 \pm 0.002$ \\
\hline 78 & 7.10 & 0.033 & 0.031 & & & $0.032 \pm 0.002$ \\
\hline 83 & 7.56 & 0.038 & 0.042 & 0.034 & & $0.038 \pm 0.004$ \\
\hline 88 & 8.02 & 0.032 & 0.028 & & & $0.030 \pm 0.003$ \\
\hline 93 & 8.92 & 0.024 & 0.024 & 0.023 & & $0.024 \pm 0.000$ \\
\hline 100 & 10.17 & 0.030 & 0.020 & 0.023 & & $0.025 \pm 0.005$ \\
\hline 103 & 10.71 & 0.029 & 0.023 & & & $0.026 \pm 0.005$ \\
\hline 108 & 11.60 & 0.022 & 0.023 & & & $0.023 \pm 0.001$ \\
\hline 113 & 12.50 & 0.036 & 0.029 & 0.027 & & $0.031 \pm 0.005$ \\
\hline 117 & 13.15 & 0.024 & 0.024 & 0.023 & & $0.024 \pm 0.001$ \\
\hline 120 & 13.64 & 0.025 & & & & 0.025 \\
\hline 121 & 13.80 & 0.052 & 0.049 & 0.021 & 0.022 & $0.021 \pm 0.001$ \\
\hline 124 & 15.16 & 0.018 & 0.018 & 0.013 & & $0.017 \pm 0.003$ \\
\hline 126 & 16.07 & 0.026 & & & & 0.026 \\
\hline 128 & 16.98 & 0.033 & 0.024 & & & $0.028 \pm 0.007$ \\
\hline 129.5 & 17.66 & 0.014 & & & & 0.014 \\
\hline 133.5 & 19.47 & 0.013 & 0.023 & 0.013 & & $0.016 \pm 0.006$ \\
\hline 140.5 & 21.11 & 0.017 & 0.018 & & & $0.017 \pm 0.001$ \\
\hline 147.5 & 22.64 & 0.012 & & & & 0.012 \\
\hline 151 & 23.40 & 0.017 & & & & 0.017 \\
\hline 156 & 25.00 & 0.017 & & & & 0.017 \\
\hline 161 & 26.60 & 0.016 & 0.014 & 0.015 & & $0.015 \pm 0.001$ \\
\hline 163.5 & 27.40 & 0.013 & 0.014 & & & $0.014 \pm 0.001$ \\
\hline 167.5 & 28.68 & 0.010 & 0.013 & & & $0.011 \pm 0.002$ \\
\hline 171 & 29.80 & 0.025 & 0.018 & & & $0.021 \pm 0.005$ \\
\hline 173.5 & 30.32 & 0.011 & 0.011 & 0.012 & & $0.011 \pm 0.001$ \\
\hline 177.5 & 31.14 & 0.016 & 0.007 & 0.015 & & $0.013 \pm 0.005$ \\
\hline 181 & 31.87 & 0.036 & 0.014 & 0.016 & & $0.015 \pm 0.002$ \\
\hline 183 & 32.28 & 0.015 & 0.012 & 0.014 & & $0.014 \pm 0.001$ \\
\hline 187 & 33.11 & 0.012 & & & & 0.012 \\
\hline 191 & 33.94 & 0.026 & 0.025 & 0.025 & & $0.025 \pm 0.000$ \\
\hline 193 & 34.35 & 0.015 & 0.016 & & & $0.016 \pm 0.001$ \\
\hline 197 & 35.18 & 0.016 & 0.019 & & & $0.018 \pm 0.002$ \\
\hline
\end{tabular}




\begin{tabular}{|c|c|c|c|c|c|}
\hline \multirow{2}{*}{$\begin{array}{l}\text { depth } \\
(\mathrm{cm}) \\
200\end{array}$} & \multirow{2}{*}{$\begin{array}{l}\begin{array}{l}\text { cal age } \\
(\mathrm{kyr} B P)\end{array} \\
35.80\end{array}$} & \multicolumn{3}{|c|}{$\begin{array}{l}\mathrm{Cd} / \mathrm{Ca} \\
(\mu \mathrm{mol} \mathrm{mol}-1)\end{array}$} & \multirow{2}{*}{$\begin{array}{l}\begin{array}{l}\text { mean } \pm \text { std dev } \\
\left(\mu \mathrm{mol} \mathrm{mol} \mathrm{m}^{-1}\right)\end{array} \\
0.013 \pm 0.003\end{array}$} \\
\hline & & 0.012 & 0.011 & 0.016 & \\
\hline 203 & 36.67 & 0.015 & 0.020 & & $0.018 \pm 0.003$ \\
\hline 207 & 37.83 & 0.012 & & & 0.012 \\
\hline 210 & 38.70 & 0.016 & 0.015 & & $0.016 \pm 0.001$ \\
\hline 213 & 39.57 & 0.019 & 0.014 & & $0.017 \pm 0.003$ \\
\hline 217 & 40.73 & 0.015 & 0.019 & 0.019 & $0.018 \pm 0.002$ \\
\hline 220 & 41.60 & 0.013 & 0.013 & & $0.013 \pm 0.000$ \\
\hline 223 & 41.92 & 0.018 & 0.021 & & $0.020 \pm 0.002$ \\
\hline 230 & 42.65 & 0.016 & 0.020 & & $0.018 \pm 0.003$ \\
\hline 233 & 42.97 & 0.016 & 0.016 & & $0.016 \pm 0.001$ \\
\hline 240 & 43.70 & 0.018 & 0.017 & & $0.017 \pm 0.000$ \\
\hline 250 & 45.74 & 0.017 & 0.014 & & $0.016 \pm 0.002$ \\
\hline 253 & 46.35 & 0.018 & & & 0.018 \\
\hline 260 & 47.77 & 0.016 & & & 0.016 \\
\hline 263 & 48.39 & 0.018 & 0.013 & & $0.016 \pm 0.003$ \\
\hline 267 & 49.20 & 0.017 & 0.012 & & $0.015 \pm 0.003$ \\
\hline 270 & 49.80 & 0.020 & & & 0.020 \\
\hline 273 & 50.40 & 0.015 & & & 0.015 \\
\hline 280 & 51.80 & 0.013 & & & 0.013 \\
\hline
\end{tabular}

Three italicized data are considered to be contaminated, and are not included in the calculation of means. 
Table 1.3. All C. kullenbergi carbon and oxygen isotope data from core OC205-2-103GGC

\begin{tabular}{|c|c|c|c|}
\hline $\begin{array}{l}\text { depth } \\
(\mathrm{cm})\end{array}$ & $\begin{array}{l}\text { cal age } \\
\text { (kyr BP) }\end{array}$ & $\begin{array}{l}\delta^{13} \mathrm{C} \\
(\% \circ \mathrm{PDB})\end{array}$ & $\begin{array}{l}\delta^{18} \mathrm{O} \\
(\% \circ \mathrm{PDB})\end{array}$ \\
\hline 7.5 & 0.38 & 1.28 & 2.14 \\
\hline 10 & 0.51 & 1.24 & 2.26 \\
\hline 10 & 0.51 & 1.24 & 2.16 \\
\hline 13 & 0.81 & 0.97 & 2.08 \\
\hline 13 & 0.81 & 1.08 & 2.11 \\
\hline 17 & 1.20 & 1.02 & 2.09 \\
\hline 17 & 1.20 & 1.18 & 2.01 \\
\hline 20 & 1.50 & 1.22 & 1.97 \\
\hline 30 & 2.48 & 1.16 & 2.11 \\
\hline 40 & 3.47 & 1.21 & 1.95 \\
\hline 40 & 3.47 & 1.40 & 2.20 \\
\hline 42 & 3.67 & 1.29 & 2.25 \\
\hline 46 & 4.06 & 1.15 & 2.25 \\
\hline 46 & 4.06 & 1.01 & 2.29 \\
\hline 50 & 4.46 & 0.95 & 2.28 \\
\hline 50 & 4.46 & 1.21 & 2.08 \\
\hline 52 & 4.65 & 1.22 & 2.15 \\
\hline 52 & 4.65 & 1.25 & 2.17 \\
\hline 56 & 5.05 & 1.26 & 2.22 \\
\hline 56 & 5.05 & 1.30 & 1.97 \\
\hline 60 & 5.44 & 1.17 & 2.37 \\
\hline 60 & 5.44 & 1.18 & 2.26 \\
\hline 63 & 5.73 & 0.65 & 2.35 \\
\hline 63 & 5.73 & 1.16 & 1.98 \\
\hline 63 & 5.73 & 1.24 & 2.33 \\
\hline 67 & 6.10 & 1.12 & 2.09 \\
\hline 67 & 6.10 & 1.49 & 2.15 \\
\hline 70 & 6.37 & 1.11 & 2.13 \\
\hline 70 & 6.37 & 1.38 & 1.99 \\
\hline 73 & 6.65 & 0.55 & 2.40 \\
\hline 73 & 6.65 & 1.20 & 2.13 \\
\hline 77 & 7.01 & 0.73 & 2.15 \\
\hline 80 & 7.29 & 1.19 & 2.23 \\
\hline 80 & 7.29 & 1.32 & 2.23 \\
\hline 83 & 7.56 & 1.29 & 2.40 \\
\hline 87 & 7.93 & 0.69 & 2.40 \\
\hline 87 & 7.93 & 0.80 & 2.16 \\
\hline 87 & 7.93 & 1.37 & 2.02 \\
\hline 90 & 8.38 & 1.21 & 2.18 \\
\hline 93 & 8.92 & 1.15 & 2.22 \\
\hline 97 & 9.63 & 0.56 & 2.18 \\
\hline 97 & 9.63 & 0.98 & 2.33 \\
\hline 97 & 9.63 & 1.16 & 2.91 \\
\hline
\end{tabular}




\begin{tabular}{|c|c|c|c|}
\hline $\begin{array}{l}\text { depth } \\
\text { (cm) }\end{array}$ & $\begin{array}{l}\text { cal age } \\
(\text { kyr BP) }\end{array}$ & $\begin{array}{l}\delta^{13} \mathrm{C} \\
(\% \circ \mathrm{PDB})\end{array}$ & $\begin{array}{l}\delta^{18} \mathrm{O} \\
(\% \circ \mathrm{PDB})\end{array}$ \\
\hline 100 & 10.17 & 1.15 & 2.43 \\
\hline 100 & 10.17 & 1.31 & 2.94 \\
\hline 103 & 10.71 & 1.04 & 2.25 \\
\hline 107 & 11.42 & 1.02 & 2.49 \\
\hline 107 & 11.42 & 1.09 & 3.19 \\
\hline 107 & 11.42 & 1.17 & 2.48 \\
\hline 110 & 11.96 & 1.09 & 2.19 \\
\hline 110 & 11.96 & 1.32 & 2.92 \\
\hline 113 & 12.50 & 1.23 & 2.88 \\
\hline 113 & 12.50 & 1.29 & 2.73 \\
\hline 117 & 13.15 & 0.90 & 2.82 \\
\hline 117 & 13.15 & 1.04 & 2.88 \\
\hline 120 & 13.64 & 1.18 & 3.21 \\
\hline 120 & 13.64 & 1.24 & 2.97 \\
\hline 121 & 13.80 & 1.16 & 2.83 \\
\hline 123 & 14.71 & 1.09 & 2.59 \\
\hline 123 & 14.71 & 1.58 & 4.10 \\
\hline 125 & 15.62 & 1.47 & 4.18 \\
\hline 125 & 15.62 & 1.63 & 4.12 \\
\hline 127 & 16.52 & 1.60 & 4.33 \\
\hline 128 & 16.98 & 1.32 & 4.02 \\
\hline 128 & 16.98 & 1.48 & 4.18 \\
\hline 129 & 17.43 & 1.44 & 4.20 \\
\hline 129 & 17.43 & 1.48 & 3.83 \\
\hline 129 & 17.43 & 1.53 & 4.02 \\
\hline 130 & 17.88 & 1.55 & 4.09 \\
\hline 130 & 17.88 & 1.66 & 3.97 \\
\hline 133 & 19.25 & 1.42 & 3.99 \\
\hline 133 & 19.25 & 1.49 & 3.93 \\
\hline 134 & 19.70 & 1.50 & 3.99 \\
\hline 137 & 20.35 & 1.61 & 4.23 \\
\hline 137 & 20.35 & 1.73 & 4.40 \\
\hline 140 & 21.01 & 1.64 & 4.02 \\
\hline 140 & 21.01 & 1.66 & 3.90 \\
\hline 141 & 21.22 & 1.48 & 3.37 \\
\hline 141 & 21.22 & 1.52 & 3.75 \\
\hline 141 & 21.22 & 1.54 & 3.95 \\
\hline 141 & 21.22 & 1.61 & 4.12 \\
\hline 147 & 22.53 & 1.48 & 3.51 \\
\hline 147 & 22.53 & 1.66 & 3.79 \\
\hline 150 & 23.18 & 1.63 & 4.16 \\
\hline 150 & 23.18 & 1.68 & 3.88 \\
\hline 151 & 23.40 & 1.55 & 3.60 \\
\hline 151 & 23.40 & 1.55 & 3.90 \\
\hline 151 & 23.40 & 1.57 & 4.07 \\
\hline
\end{tabular}




\begin{tabular}{|c|c|c|c|}
\hline $\begin{array}{l}\text { depth } \\
(\mathrm{cm})\end{array}$ & $\begin{array}{l}\text { cal age } \\
\text { (kyr BP) }\end{array}$ & $\begin{array}{l}\delta^{13} \mathrm{C} \\
(\% \circ \mathrm{PDB})\end{array}$ & $\begin{array}{l}\delta^{18} \mathrm{O} \\
(\% \circ \mathrm{PDB})\end{array}$ \\
\hline 152 & 23.72 & 1.53 & 3.96 \\
\hline 152 & 23.72 & 1.58 & 3.66 \\
\hline 153 & 24.04 & 1.54 & 3.94 \\
\hline 154 & 24.36 & 1.50 & 2.72 \\
\hline 154 & 24.36 & 1.53 & 3.60 \\
\hline 154 & 24.36 & 1.69 & 3.98 \\
\hline 155 & 24.68 & 1.40 & 3.08 \\
\hline 155 & 24.68 & 1.51 & 3.52 \\
\hline 156 & 25.00 & 1.57 & 3.70 \\
\hline 156 & 25.00 & 1.70 & 4.08 \\
\hline 157 & 25.32 & 1.51 & 3.46 \\
\hline 157 & 25.32 & 1.62 & 3.53 \\
\hline 160 & 26.28 & 1.63 & 3.76 \\
\hline 160 & 26.28 & 1.66 & 3.88 \\
\hline 161 & 26.60 & 1.58 & 3.54 \\
\hline 161 & 26.60 & 1.58 & 3.71 \\
\hline 163 & 27.24 & 1.56 & 3.41 \\
\hline 163 & 27.24 & 1.58 & 3.64 \\
\hline 164 & 27.56 & 1.28 & 3.36 \\
\hline 164 & 27.56 & 1.50 & 3.59 \\
\hline 164 & 27.56 & 1.63 & 3.59 \\
\hline 167 & 28.52 & 1.59 & 3.39 \\
\hline 167 & 28.52 & 1.66 & 3.76 \\
\hline 170 & 29.48 & 1.37 & 3.20 \\
\hline 170 & 29.48 & 1.56 & 3.80 \\
\hline 171 & 29.80 & 1.53 & 3.62 \\
\hline 171 & 29.80 & 1.56 & 3.25 \\
\hline 171 & 29.80 & 1.66 & 3.69 \\
\hline 172 & 30.01 & 1.61 & 3.63 \\
\hline 172 & 30.01 & 1.62 & 3.74 \\
\hline 173 & 30.21 & 1.26 & 3.46 \\
\hline 173 & 30.21 & 1.36 & 3.39 \\
\hline 173 & 30.21 & 1.68 & 3.55 \\
\hline 174 & 30.42 & 1.52 & 3.18 \\
\hline 174 & 30.42 & 1.65 & 3.80 \\
\hline 175 & 30.63 & 1.44 & 3.38 \\
\hline 175 & 30.63 & 1.49 & 3.59 \\
\hline 175 & 30.63 & 1.50 & 3.34 \\
\hline 176 & 30.83 & 1.56 & 3.12 \\
\hline 176 & 30.83 & 1.61 & 3.36 \\
\hline 176 & 30.83 & 1.69 & 3.88 \\
\hline 177 & 31.04 & 1.53 & 3.42 \\
\hline 177 & 31.04 & 1.61 & 3.61 \\
\hline 178 & 31.25 & 1.48 & 3.06 \\
\hline 178 & 31.25 & 1.54 & 3.54 \\
\hline
\end{tabular}




\begin{tabular}{|c|c|c|c|}
\hline $\begin{array}{l}\text { depth } \\
(\mathrm{cm})\end{array}$ & $\begin{array}{l}\text { cal age } \\
\text { (kyr BP) }\end{array}$ & $\begin{array}{l}\delta^{13} \mathrm{C} \\
(\% \circ \mathrm{PDB})\end{array}$ & $\begin{array}{l}\delta^{18} \mathrm{O} \\
(\% \circ \mathrm{PDB})\end{array}$ \\
\hline 179 & 31.46 & 1.54 & 3.38 \\
\hline 179 & 31.46 & 1.59 & 3.54 \\
\hline 179 & 31.46 & 1.62 & 3.54 \\
\hline 180 & 31.66 & 1.51 & 3.32 \\
\hline 180 & 31.66 & 1.57 & 3.51 \\
\hline 180 & 31.66 & 1.59 & 3.46 \\
\hline 180 & 31.66 & 1.65 & 3.65 \\
\hline 181 & 31.87 & 1.37 & 3.16 \\
\hline 181 & 31.87 & 1.37 & 3.20 \\
\hline 181 & 31.87 & 1.37 & 2.84 \\
\hline 183 & 32.28 & 1.30 & 3.49 \\
\hline 183 & 32.28 & 1.42 & 3.52 \\
\hline 183 & 32.28 & 1.46 & 3.28 \\
\hline 187 & 33.11 & 1.43 & 2.92 \\
\hline 187 & 33.11 & 1.53 & 3.54 \\
\hline 187 & 33.11 & 1.54 & 3.40 \\
\hline 190 & 33.73 & 1.37 & 3.23 \\
\hline 190 & 33.73 & 1.47 & 3.36 \\
\hline 190 & 33.73 & 1.47 & 3.30 \\
\hline 191 & 33.94 & 1.26 & 3.13 \\
\hline 191 & 33.94 & 1.35 & 3.12 \\
\hline 193 & 34.35 & 1.13 & 2.83 \\
\hline 193 & 34.35 & 1.46 & 3.37 \\
\hline 197 & 35.18 & 1.34 & 3.29 \\
\hline 197 & 35.18 & 1.39 & 3.30 \\
\hline 197 & 35.18 & 1.54 & 3.68 \\
\hline 197 & 35.18 & 1.61 & 3.60 \\
\hline 200 & 35.80 & 1.55 & 3.31 \\
\hline 200 & 35.80 & 1.65 & 3.35 \\
\hline 203 & 36.67 & 1.50 & 3.56 \\
\hline 203 & 36.67 & 1.57 & 3.43 \\
\hline 207 & 37.83 & 0.95 & 3.13 \\
\hline 207 & 37.83 & 1.52 & 3.31 \\
\hline 207 & 37.83 & 1.56 & 3.52 \\
\hline 210 & 38.70 & 1.25 & 3.19 \\
\hline 210 & 38.70 & 1.43 & 3.12 \\
\hline 210 & 38.70 & 1.52 & 3.19 \\
\hline 210 & 38.70 & 1.57 & 3.41 \\
\hline 211 & 38.99 & 1.49 & 3.53 \\
\hline 211 & 38.99 & 1.53 & 3.39 \\
\hline 211 & 38.99 & 1.57 & 3.34 \\
\hline 212 & 39.28 & 1.30 & 3.05 \\
\hline 212 & 39.28 & 1.42 & 3.49 \\
\hline 212 & 39.28 & 1.48 & 3.13 \\
\hline
\end{tabular}




\begin{tabular}{|c|c|c|c|}
\hline $\begin{array}{l}\text { depth } \\
(\mathrm{cm})\end{array}$ & $\begin{array}{l}\text { cal age } \\
\text { (kyr BP) }\end{array}$ & $\begin{array}{l}\delta^{13} \mathrm{C} \\
(\% \circ \mathrm{PDB})\end{array}$ & $\begin{array}{l}\delta^{18} \mathrm{O} \\
(\% \circ \mathrm{PDB})\end{array}$ \\
\hline 214 & 39.86 & 1.45 & 3.39 \\
\hline 214 & 39.86 & 1.49 & 3.20 \\
\hline 214 & 39.86 & 1.51 & 3.26 \\
\hline 215 & 40.15 & 1.42 & 2.99 \\
\hline 215 & 40.15 & 1.46 & 3.16 \\
\hline 215 & 40.15 & 1.46 & 3.27 \\
\hline 215 & 40.15 & 1.49 & 3.49 \\
\hline 216 & 40.44 & 1.30 & 2.73 \\
\hline 216 & 40.44 & 1.43 & 3.36 \\
\hline 216 & 40.44 & 1.52 & 3.36 \\
\hline 217 & 40.73 & 1.40 & 3.31 \\
\hline 217 & 40.73 & 1.46 & 3.27 \\
\hline 218 & 41.02 & 1.38 & 3.08 \\
\hline 218 & 41.02 & 1.45 & 3.30 \\
\hline 218 & 41.02 & 1.46 & 3.32 \\
\hline 219 & 41.31 & 1.36 & 3.35 \\
\hline 219 & 41.31 & 1.38 & 3.20 \\
\hline 219 & 41.31 & 1.40 & 3.25 \\
\hline 220 & 41.60 & 0.98 & 3.43 \\
\hline 220 & 41.60 & 1.43 & 3.06 \\
\hline 223 & 41.92 & 1.34 & 3.11 \\
\hline 223 & 41.92 & 1.36 & 3.02 \\
\hline 223 & 41.92 & 1.39 & 3.19 \\
\hline 227 & 42.34 & 1.14 & 2.82 \\
\hline 227 & 42.34 & 1.33 & 3.20 \\
\hline 227 & 42.34 & 1.37 & 3.43 \\
\hline 230 & 42.65 & 1.31 & 3.28 \\
\hline 230 & 42.65 & 1.50 & 3.21 \\
\hline 233 & 42.97 & 1.40 & 3.22 \\
\hline 233 & 42.97 & 1.40 & 3.31 \\
\hline 233 & 42.97 & 1.54 & 3.49 \\
\hline 237 & 43.39 & 1.26 & 3.34 \\
\hline 237 & 43.39 & 1.36 & 3.32 \\
\hline 237 & 43.39 & 1.37 & 3.18 \\
\hline 237 & 43.39 & 1.50 & 3.27 \\
\hline 240 & 43.70 & 1.01 & 3.11 \\
\hline 240 & 43.70 & 1.33 & 2.98 \\
\hline 243 & 44.31 & 1.29 & 3.26 \\
\hline 243 & 44.31 & 1.35 & 2.81 \\
\hline 243 & 44.31 & 1.40 & 3.32 \\
\hline 243 & 44.31 & 1.41 & 3.37 \\
\hline 247 & 45.13 & 1.33 & 3.27 \\
\hline 247 & 45.13 & 1.33 & 3.22 \\
\hline 250 & 45.74 & 1.33 & 3.50 \\
\hline 253 & 46.35 & 1.21 & 3.25 \\
\hline 253 & 46.35 & 1.22 & 2.85 \\
\hline
\end{tabular}




\begin{tabular}{llll}
\hline $\begin{array}{l}\text { depth } \\
(\mathrm{cm})\end{array}$ & $\begin{array}{l}\text { cal age } \\
(\mathrm{kyr} B \mathrm{~B})\end{array}$ & $\begin{array}{l}\delta^{13} \mathrm{C} \\
(\% \text { PDB })\end{array}$ & $\begin{array}{l}\delta^{18 \mathrm{O}} \\
(\% \circ \mathrm{PDB})\end{array}$ \\
\hline 257 & 47.16 & 1.07 & 3.23 \\
257 & 47.16 & 1.37 & 3.09 \\
260 & 47.77 & 1.27 & 3.00 \\
260 & 47.77 & 1.32 & 3.15 \\
263 & 48.39 & 0.92 & 2.79 \\
263 & 48.39 & 1.02 & 3.14 \\
263 & 48.39 & 1.26 & 2.86 \\
267 & 49.20 & 0.92 & 2.73 \\
267 & 49.20 & 1.10 & 3.11 \\
267 & 49.20 & 1.22 & 3.23 \\
270 & 49.80 & 0.87 & 2.95 \\
273 & 50.40 & 1.09 & 3.42 \\
273 & 50.40 & 1.22 & 3.28 \\
273 & 50.40 & 1.50 & 3.01 \\
277 & 51.20 & 1.27 & 3.13 \\
277 & 51.20 & 1.38 & 3.40 \\
277 & 51.20 & 1.54 & 3.88 \\
280 & 51.80 & 1.37 & 3.86 \\
280 & 51.80 & 1.49 & 3.69 \\
\hline
\end{tabular}

All measurements were made on single $C$. kullenbergi shells. Some of these data $(<30 \%)$ were originally presented by Slowey and Cury (1995). 


\title{
Chapter 2. Zinc concentrations in benthic foraminifera reflect seawater chemistry
}

\begin{abstract}
Zn} / \mathrm{Ca}$ and $\mathrm{Cd} / \mathrm{Ca}$ ratios have been measured in several taxa of Holocene-aged benthic foraminifera from throughout the world's oceans. $\mathrm{Zn} / \mathrm{Ca}$ is controlled by bottom water dissolved $\mathrm{Zn}$ concentration and, like $\mathrm{Cd} / \mathrm{Ca}$ and $\mathrm{Ba} / \mathrm{Ca}$, by bottom water saturation state with respect to calcite. Measurements on "live-collected" foraminifera suggest that the saturation effect occurs during growth, and is not a post-depositional artifact. $\mathrm{Zn} / \mathrm{Ca}$ could be a sensitive paleoceanographic tracer because deep water masses have characteristic $\mathrm{Zn}$ concentrations that increase about ten-fold from the deep North Atlantic to the deep North Pacific. In addition, since $\mathrm{Zn} / \mathrm{Ca}$ responds to a different range of saturation states than $\mathrm{Cd} / \mathrm{Ca}$, the two may be used together to evaluate changes in deep water carbonate ion $\left(\mathrm{CO}_{3}{ }^{2-}\right)$ concentration.
\end{abstract}

\section{Introduction}

Much of our knowledge of the past distribution and circulation of deep water masses has been derived from carbon isotopic $\left(\delta^{13} \mathrm{C}\right)$ and trace metal concentration $(\mathrm{Cd} / \mathrm{Ca}, \mathrm{Ba} / \mathrm{Ca})$ measurements of benthic foraminiferal shells (e.g., Boyle and Keigwin, 1982; Curry and Lohmann, 1982; Curry et al., 1988; Duplessy et al., 1988; Lea and Boyle, 1990; Boyle, 1992; Oppo and Lehman, 1993; Sarnthein et al., 1994). $\delta^{13} \mathrm{C}$ and $\mathrm{Cd} / \mathrm{Ca}$-based reconstructions of last glacial maximum (LGM) deep circulation agree on a gross scale, but differ significantly in certain details. For example, $\delta^{13} \mathrm{C}$ suggests that the deep glacial Southern Ocean was more nutrient-rich than the Pacific (Curry et al., 1988), while $\mathrm{Cd} / \mathrm{Ca}$ measurements fall between Atlantic and Pacific values, like today (Boyle, 1992). Several mechanisms have been proposed to explain such discrepancies, including air-sea exchange (Charles et al., 1993; Lynch-Stieglitz and Fairbanks, 1994), foraminiferal microhabitat effects (Mackensen et al., 1993), and bottom water undersaturation with respect to calcite (McCorkle et al., 1995). The extent to which these mechanisms operate is not well understood, however, and there is a clear need for additional deep water nutrient tracers. $\mathrm{Ba} / \mathrm{Ca}$ is one such tracer, though its applicability is somewhat complicated by an apparent glacial increase in Ba flux from Atlantic sediments (Martin and Lea, 1998). 
Benthic foraminiferal zinc concentration $(\mathrm{Zn} / \mathrm{Ca})$ is well-suited to be a sensitive paleocirculation tool.

\section{Dissolved Zn in seawater}

$\mathrm{Zn}$ is an essential micronutrient for many marine organisms, second only to iron among the biologically important trace metals (e.g., Bruland et al., 1991; Morel et al., 1994; Sunda and Huntsman, 1995). This contributes to the nutrient-like character of its dissolved vertical profile in seawater, with near-zero concentrations in most surface waters and maximum values below $1000 \mathrm{~m}$ depth (Bruland et al., 1978) (Figure 2.1). The overall distribution of dissolved $\mathrm{Zn}$ is very similar to that of $\mathrm{Si}$, with correlation between the two elements as high as $\mathrm{r}^{2}=0.99$ in the North Pacific (Bruland et al., 1978; Bruland, 1980). Although regional variations in $\mathrm{Zn}$ :Si ratios exist above $1000 \mathrm{~m}$ water depth, the correlation holds at $\mathrm{r}^{2}=0.98$ in global deep waters (Bruland et al., 1978; Martin et al., 1989; Bruland, 1980; Bruland and Franks, 1983; Martin et al., 1990; P. Yeats and J. Dalziel, unpublished data) (Figure 2.2). This strong covariance is believed to be due to their similar patterns of biological uptake and regeneration, mainly by diatoms, not to the relatively unimportant incorporation of $\mathrm{Zn}$ into biogenic opal (Collier and Edmond, 1984; Ellwood and Hunter, 1996).

$\mathrm{Zn}$ concentrations range from $<1 \mathrm{nmol} \mathrm{kg}^{-1}$ in the deep North Atlantic (P. Yeats and J. Dalziel, unpublished data) to $>10 \mathrm{nmol} \mathrm{kg}^{-1}$ in the deep North Pacific (Martin et al., 1989). There is a particularly large ( $\sim$ seven-fold) increase between the deep North Atlantic and the deep South Atlantic (Martin et al, 1990), much larger than the corresponding $\mathrm{Cd}$ and Ba gradients (Boyle, 1988a; Lea and Boyle, 1989) (Figure 2.3). This suggests that $\mathrm{Zn}$ may be a very sensitive tracer of the glacial/interglacial interactions between North Atlantic Deep Water (NADW) and southern source deep waters such as Circumpolar Deep Water (CPDW) and Antarctic Bottom Water (AABW). Note, however, that $\mathrm{Cd}$ is expected to be a more sensitive tracer of interactions between Antarctic Intermediate Water (AAIW) and NADW. To date, only two benthic 
foraminiferal $\mathrm{Zn} / \mathrm{Ca}$ measurements have been published, $3.0 \mu \mathrm{mol} \mathrm{mol}^{-1}$ for Pyrgo and $37.3 \mu \mathrm{mol} \mathrm{mol}^{-1}$ for Uvigerina (Boyle, 1981), and the higher value is certainly contaminated. I have therefore carried out a "core top calibration" to show that foraminifera reflect bottom water dissolved $\mathrm{Zn}$ levels.

\section{Materials and methods}

$\mathrm{Zn}, \mathrm{Cd}$, and $\mathrm{Mn}$ concentrations were measured in the shells of several taxa of cosmopolitan benthic foraminifera, with emphasis on Cibicidoides wuellerstorfi and Uvigerina spp. Foraminifera were picked from 33 Holocene sediment core tops from around the world's deep ocean $(>1500 \mathrm{~m}$ depth; Table 2.1). Sediments were verified to be Holocene in age using published benthic and planktonic foraminiferal $\delta^{18} \mathrm{O}$, radiocarbon dates, and bulk sediment percent $\mathrm{CaCO}_{3}$ (Table 2.1). Holocene thicknesses vary from $<10$ $\mathrm{cm}$ in the Vema Channel (deep AII107 cores) to $\sim 175 \mathrm{~cm}$ off of Cap Blanc (ODP 658A), with most cores containing at least $15 \mathrm{~cm}$ of Holocene material (Figure 2.4). Omission of the lowest sedimentation rate cores does not alter my conclusions. Eight additional multicore tops from the Brazil Basin were also used to compare data from "live" and "dead" benthic foraminifera.

Benthic foraminiferal samples, each consisting of $\sim 5$ to 15 individuals $(>250 \mu \mathrm{m})$, were cleaned following the methods of Boyle and Keigwin (1985/86) as modified by Rosenthal (1994) and Boyle and Rosenthal (1996). Specimens stained with Rose Bengal were pretreated with bleach overnight ( $\mathrm{P}$. Martin, personal communication). Additional precautions were taken to minimize the risk of laboratory contamination, which has historically been a major obstacle to $\mathrm{Zn}$ work (Bruland et al., 1978). $\mathrm{Zn}, \mathrm{Cd}$, and $\mathrm{Mn}$ were measured sequentially by graphite furnace atomic absorption spectrophotometry (AAS) and $\mathrm{Ca}$ was measured by flame AAS, all on a Hitachi Z-8200. Analytical precision, based on frequent analyses of three consistency standards, is $\pm 2-3 \%$ for $\mathrm{Zn}, \pm 3-6 \%$ for $\mathrm{Cd}$, \pm 8 $9 \%$ for $\mathrm{Mn}$, and $\pm 1 \%$ for $\mathrm{Ca}$ (see Appendix 1 for further details on analytical methods and precision). 
Modern dissolved $\mathrm{Zn}$ concentrations in bottom waters overlying each core site were estimated from nearest GEOSECS expedition Si measurements (Bainbridge, 1981; Broecker et al., 1982; Weiss et al., 1983) and the global deep water Zn:Si relationship (Figure 2.2):

$$
[\mathrm{Zn}]=0.052[\mathrm{Si}]+0.79
$$

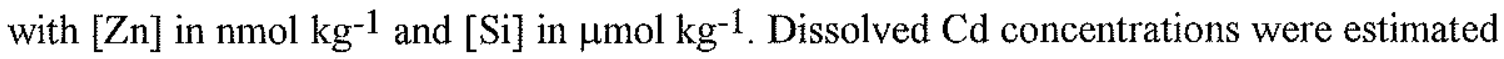
from nearest GEOSECS P measurements and the global Cd:P relationship of Boyle (1988a):

$$
\begin{aligned}
& {[\mathrm{Cd}]=0.208[\mathrm{P}](\text { for }[\mathrm{P}]<1.34 \mu \mathrm{mol} \mathrm{kg}-1)} \\
& {[\mathrm{Cd}]=0.398[\mathrm{P}]-0.254\left(\text { for }[\mathrm{P}]>1.34 \mu \mathrm{mol} \mathrm{kg}{ }^{-1}\right)}
\end{aligned}
$$

with [Cd] in nmol kg-1 and $[\mathrm{P}]$ in $\mu \mathrm{mol} \mathrm{kg}-1$. Dissolved $\mathrm{Ca}$ concentrations were taken to be constant at $0.01 \mathrm{~mol} \mathrm{~kg}^{-1}$ (Boyle, 1992).

Degree of calcite saturation, defined by:

$$
\Delta \mathrm{CO}_{3}{ }^{2-}=\left[\mathrm{CO}_{3}{ }^{2-}\right]_{\text {in situ }}-\left[\mathrm{CO}_{3}{ }^{2-}\right]_{\text {saturation }}
$$

was calculated at each site from nearest GEOSECS measurements of alkalinity, $\Sigma \mathrm{CO}_{2}$, temperature, and salinity. A constant of $15 \mu \mathrm{mol} \mathrm{kg}-1$ was subtracted from all Indian and Pacific $\Sigma \mathrm{CO}_{2}$ titration data, as recommended by Broecker et al. (1982) and Weiss et al. (1983). More recent work, based on a comparison to WOCE and JGOFS data, suggests that the correction constant may be as high as $22.5 \mu \mathrm{mol} \mathrm{kg}{ }^{-1}$ in the Indian Ocean (Sabine et al., 1999). As recommended by UNESCO (1987), equations for the first and second dissociation constants of carbonic acid are from Dickson and Millero (1987); the dissociation constant of boric acid is from Millero (1979); the solubility products for calcite and aragonite are from Mucci (1983); and the pressure effects on the various constants are from Millero (1979) (see Appendix 2 for full equations). The resulting $\triangle \mathrm{CO}_{3}{ }^{2-}$ values are significantly offset from those calculated by GEOSECS (Bainbridge, 1981; Broecker et al., 1982; Weiss et al., 1983), mainly because of a difference in the pressure effect on calcite solubility. The offset is therefore a function of water depth, and ranges from about $+6 \mu \mathrm{mol} \mathrm{kg}-1$ at $1660 \mathrm{~m}$ to $-8 \mu \mathrm{mol} \mathrm{kg}^{-1}$ at $4556 \mathrm{~m}$. 


\section{Results and discussion}

$\mathrm{Zn} / \mathrm{Ca}$ in $\mathrm{C}$. wuellerstorfi and Uvigerina spp.

Measured Holocene C. wuellerstorfi and Uvigerina spp. $\mathrm{Zn} / \mathrm{Ca}$ values range between 1.22 and $5.84 \mu \mathrm{mol} \mathrm{mol}-1$ (Figure 2.5, Table 2.1). The data correlate generally well with predicted seawater $\mathrm{Zn}$ concentrations $\left(\mathrm{r}^{2}=0.67, \mathrm{p}<<0.001\right)$, indicating that $C$. wuellerstorfi and Uvigerina spp. do reflect overlying $\mathrm{Zn}$ levels. Lowest $\mathrm{Zn} / \mathrm{Ca}$ values are found in the North Atlantic (mean of $1.8 \pm 0.5 \mu \mathrm{mol} \mathrm{mol}^{-1}$ ), intermediate values in the tropical and South Atlantic $(2.8 \pm 0.6 \mu \mathrm{mol} \mathrm{mol}-1)$, and highest values in the Indian and Pacific $\left(4.4 \pm 0.7 \mu \mathrm{mol} \mathrm{mol}^{-1}\right.$ ), following the expected pattern. All but three of the $\mathrm{Mn} / \mathrm{Ca}$ ratios in these samples are below $30 \mu \mathrm{mol} \mathrm{mol}^{-1}$ (Figure 2.6, Table 2.2), and there is no evidence of $\mathrm{MnCO}_{3}$-related $\mathrm{Zn}$ contamination.

Note, however, that many of the Pacific, Indian, and deepest South Atlantic $\mathrm{Zn} / \mathrm{Ca}$ data (from waters with $\mathrm{Zn}>4 \mathrm{nmol} \mathrm{kg}^{-1}$ ) fall below the trend suggested by the other Atlantic data. This pattern is expected if apparent $\mathrm{Zn}$ partition coefficients, defined by:

$$
D_{\mathrm{Zn}}=(\mathrm{Zn} / \mathrm{Ca})_{\text {foram }} /(\mathrm{Zn} / \mathrm{Ca})_{\text {seawater }}
$$

are decreased in waters that are near or below saturation with respect to calcite, as $C$. wuellerstorfi $\mathrm{Cd}$ and $\mathrm{Ba}$ apparent partition coefficients are (McCorkle et al., 1995). Figure 2.7 shows $D_{\mathrm{Zn}}$ plotted $v$ s. $\Delta \mathrm{CO}_{3}^{2-}$; in waters with $\Delta \mathrm{CO}_{3}^{2-}$ below $\sim 25 \mu \mathrm{mol} \mathrm{kg}{ }^{-1}, D_{\mathrm{Zn}}$ decreases with decreasing saturation. These data can be fitted with a simple two-part linear relationship, allowing us to predict $D_{\mathrm{Zn}}$ from $\Delta \mathrm{CO}_{3}{ }^{2-}$ :

$$
\begin{aligned}
& D_{\mathrm{Zn}}=0.15 \Delta \mathrm{CO}_{3}^{2-}+5.25\left(\text { for } \Delta \mathrm{CO}_{3}^{2-<25 \mu \mathrm{mol} \mathrm{kg}-1}\right) \\
& D_{\mathrm{Zn}}=9\left(\text { for } \Delta \mathrm{CO}_{3}{ }^{2-}>25 \mu \mathrm{mol} \mathrm{kg}{ }^{-1}\right)
\end{aligned}
$$

The true relationship is likely to be non-linear, but the present data do not warrant anything more complex than two line segments. Such a simple relationship, which describes the data reasonably well, is preferable to a best fit, which would necessarily change with each new datum added to the calibration. Nevertheless, Equations 2.6 and 2.7 are certainly subject to future modification. Also, although C. wuellerstorfi and Uvigerina 
agree rather well in these samples, there are no Uvigerina data from waters with $\Delta \mathrm{CO}_{3}{ }^{2-}$ values between $\sim 0$ and $35 \mu \mathrm{mol} \mathrm{kg-1}$. Thus it is possible that the true Uvigerina relationship is different from Equations 2.6 and 2.7. Simple modeling of $D_{\mathrm{Zn}}$ as a function of two variables $\left(\Delta \mathrm{CO}_{3}{ }^{2-}\right.$ plus water depth, and $\Delta \mathrm{CO}_{3}{ }^{2-}$ plus temperature $)$ indicates that water depth and temperature are insignificant factors within the range of the data (Figure 2.8).

This $\Delta \mathrm{CO}_{3}{ }^{2-}$-dependent $D_{\mathrm{Zn}}$ can then be applied to foraminiferal $\mathrm{Zn} / \mathrm{Ca}$ to yield an inferred seawater $\mathrm{Zn}$ concentration:

$$
\mathrm{Zn}_{\mathrm{W}}=\left[(\mathrm{Zn} / \mathrm{Ca})_{\text {foram }} / \mathrm{D}_{\mathrm{Zn}}\right][\mathrm{Ca}]_{\text {seawater }}
$$

Applying this conversion to the core top data (in a somewhat circular fashion) increases the correlation between foraminiferal and seawater data significantly $\left(\mathrm{r}^{2}=0.92\right.$; Figure 2.9$)$. The remaining scatter in this relationship may be due to: uncertainties in estimating bottom water $\mathrm{Si}$ and $\Delta \mathrm{CO}_{3}{ }^{2-}$ from GEOSECS data; uncertainties in predicting seawater $\mathrm{Zn}$ from $\mathrm{Si}$ estimates; presence of older foraminifera due to bioturbation and/or lack of latest Holocene sediment; and occasional laboratory contamination. The high correlation in spite of all these factors suggests that $\mathrm{Zn}$ concentrations in C. wuellerstorfi and Uvigerina are relatively precise functions of bottom water $\mathrm{Zn}$ and $\Delta \mathrm{CO}_{3}{ }^{2-}$ levels.

\section{$\mathrm{Cd} / \mathrm{Ca}$ and its relationship to seawater $\mathrm{ACO}_{3}{ }^{2-}$}

$\mathrm{Cd} / \mathrm{Ca}$ ratios were also measured in all of the above $C$. wuellerstorfi and Uvigerina core top samples (Table 2.2). For comparison to water column data, $\mathrm{Cd} / \mathrm{Ca}$ can be converted to inferred seawater $\mathrm{Cd}$ concentration $\left(\mathrm{Cd}_{\mathrm{W}}\right)$ using the depth-dependent calcitic partition coefficients of Boyle (1992):

$$
\begin{aligned}
& D_{\mathrm{Cd}}=1.3(\text { for depths }<1150 \mathrm{~m}) \\
& D_{\mathrm{Cd}}=1.3+(\text { depth }-1150) 1.6 / 1850(\text { for depths } 1150-3000 \mathrm{~m}) \\
& D_{\mathrm{Cd}}=2.9(\text { for depths }>3000 \mathrm{~m})
\end{aligned}
$$

This conversion results in a reasonably good agreement between foraminiferal and water column data $\left(\mathrm{r}^{2}=0.48, \mathrm{p}<<0.001\right.$; Figure 2.10$)$. However, as noted above, McCorkle et al. 
(1995) found that C. wuellerstorfi $D_{\mathrm{Cd}}$ is further related to bottom water saturation state with respect to calcite. I will therefore combine my $\mathrm{Cd} / \mathrm{Ca}$ data with the data of $\mathrm{McCorkle}$ et al. (1995), and Boyle (1988a, 1992), in an attempt to define the relationship between $D_{\mathrm{Cd}}$ and $\Delta \mathrm{CO}_{3}{ }^{2-}$.

This task is complicated by the depth-dependence of $D_{\mathrm{Cd}}$. One could attempt to remove the depth effect from the data using Boyle's (1992) equations, but these equations may themselves be flawed because they do not account for the $\Delta \mathrm{CO}_{3}{ }^{2-}$ effect. Ideally one would model the two effects simultaneously, but this is difficult because each appears to act only over a certain interval (for depth, between $\sim 1150$ and $3000 \mathrm{~m}$; and for $\Delta \mathrm{CO}_{3}{ }^{2-}$, below roughly $0 \mu \mathrm{mol} \mathrm{kg}^{-1}$ ). To avoid this complexity, I will start with data for which depth-dependence is apparently absent, i.e., data deeper than $3000 \mathrm{~m}$. Boyle's (1988a, 1992) C. wuellerstorfi and Uvigerina $D_{\mathrm{Cd}}$ values from cores below $3000 \mathrm{~m}$ are plotted in Figure 2.11a vs. $\Delta \mathrm{CO}_{3}{ }^{2-}$. While the mean $D_{\mathrm{Cd}}$ is $2.9 \pm 0.6$ (in agreement with Boyle's [1992] depth-dependent equations), values tend to be somewhat higher than this in oversaturated waters $(3.2 \pm 0.6)$ and lower than this in undersaturated waters $(2.6 \pm 0.4)$. Although these two means are not significantly distinct, when combined with McCorkle et al.'s (1995) data from deeper than $3000 \mathrm{~m}$ (Figure 2.11a), the overall pattern suggests that Boyle's (1992) 2.9 value may be slightly biased by samples from undersaturated waters. The addition of my deep data (Figure 2.11b) supports the distinction between oversaturation and undersaturation.

Unfortunately, there is a large amount of scatter in the relationship between apparent $D_{\mathrm{Cd}}$ and $\Delta \mathrm{CO}_{3}{ }^{2-}$. As noted above for $\mathrm{Zn} / \mathrm{Ca}$, there are various, large uncertainties involved in deriving these data. Nearest GEOSECS sites are often thousands of kilometers from the core sites, making accurate estimates of alkalinity, $\Sigma \mathrm{CO}_{2}$, and $\mathrm{P}$ difficult to obtain. Conversion of these properties into $\Delta \mathrm{CO}_{3}{ }^{2-}$ and $\mathrm{Cd}$ concentrations introduces additional error. Reasonable estimates of the uncertainties in $\mathrm{P}$, seawater $\mathrm{Cd}$, and foraminiferal $\mathrm{Cd} / \mathrm{Ca}$ result in aggregate $D_{\mathrm{Cd}}$ errors of about \pm 0.3 (North Pacific) to \pm 1 (North Atlantic) (Table 2.3). Comparison of closely spaced GEOSECS stations 
suggests that $\Delta \mathrm{CO}_{3}{ }^{2-}$ estimates are accurate to no better than \pm 5 to $10 \mu \mathrm{mol} \mathrm{kg}{ }^{-1}$ (Figure 2.12). Given that expected $D_{\mathrm{Zn}}$ errors are similarly large (Table 2.3), it is not obvious why the $D_{\mathrm{Zn}}: \Delta \mathrm{CO}_{3}{ }^{2-}$ relationship appears to be tighter. An important factor is probably the steeper slope for $D_{\mathrm{Cd}}$, i.e., $D_{\mathrm{Cd}}$ increases three-fold over $\sim 20 \mu \mathrm{mol} \mathrm{kg-1} \Delta \mathrm{CO}_{3}{ }^{2-}$, while $D_{\mathrm{Zn}}$ increases three-fold over $\sim 40 \mu \mathrm{mol} \mathrm{kg}{ }^{-1} \Delta \mathrm{CO}_{3}{ }^{2-}$ (Figures $2.7,2.11$ ). This would cause the uncertainty in $\Delta \mathrm{CO}_{3}{ }^{2-}$ to be more important for $D_{\mathrm{Cd}}$.

If the observed scatter in the relationship between $D_{\mathrm{Cd}}$ and $\Delta \mathrm{CO}_{3}{ }^{2-}$ is mainly the result of these uncertainties, one could speculate that C. wuellerstorfi and Uvigerina are actually good recorders of seawater $\mathrm{Cd}$ and $\Delta \mathrm{CO}_{3}{ }^{2-}$. The precise relationship between $D_{\mathrm{Cd}}$ and $\Delta \mathrm{CO}_{3}{ }^{2-}$ remains poorly constrained by the current data, however. I therefore propose a pair of very preliminary, simple linear equations for waters deeper than $3000 \mathrm{~m}$ (Figure 2.11b):

$$
\begin{aligned}
& D_{\mathrm{Cd}}=0.1 \Delta \mathrm{CO}_{3}^{2-}+2.5\left(\text { for } \Delta \mathrm{CO}_{3}{ }^{2-<5 \mu \mathrm{mol} \mathrm{kg}}{ }^{-1}\right) \\
& D_{\mathrm{Cd}}=3\left(\text { for } \Delta \mathrm{CO}_{3}^{2->5} \mu \mathrm{mol} \mathrm{kg}^{-1}\right)
\end{aligned}
$$

For samples from any depth, a depth correction can be applied to these equations as follows:

$$
\begin{aligned}
& D_{\mathrm{Cd}}=\left(D_{\mathrm{Cd}(\mathrm{z})}-3\right)+0.1 \Delta \mathrm{CO}_{3}^{2-}+2.5\left(\text { for } \Delta \mathrm{CO}_{3}{ }^{2-<5 \mu \mathrm{mol} \mathrm{kg}}{ }^{-1}\right) \\
& D_{\mathrm{Cd}}=\left(D_{\mathrm{Cd}(\mathrm{z})}-3\right)+3\left(\text { for } \Delta \mathrm{CO}_{3}^{2-}>5 \mu \mathrm{mol} \mathrm{kg}{ }^{-1}\right)
\end{aligned}
$$

where $D_{\mathrm{Cd}(\mathrm{z})}$ represents the $\mathrm{Cd}$ partition coefficient predicted from water depth only. Preliminary equations for $D_{\mathrm{Cd}(\mathrm{z})}$ are based on Boyle's (1992) equations, except that the $>3000 \mathrm{~m}$ maximum value is taken to be 3 :

$$
\begin{aligned}
& D_{\mathrm{Cd}(\mathrm{z})}=1.3(\text { for depths }<1150 \mathrm{~m}) \\
& D_{\mathrm{Cd}(\mathrm{z})}=1.3+(\text { depth }-1150) 1.7 / 1850(\text { for depths } 1150-3000 \mathrm{~m}) \\
& D_{\mathrm{Cd}(\mathrm{z})}=3(\text { for depths }>3000 \mathrm{~m})
\end{aligned}
$$

Application of Equations 2.14 and 2.15 to my core top $\mathrm{Cd} / \mathrm{Ca}$ data significantly improves the agreement between $\mathrm{Cd}_{\mathrm{W}}$ and estimated water column $\mathrm{Cd}$ concentrations $\left(\mathrm{r}^{2}=0.73\right.$; Figure 2.13). 
All of the above $D_{\mathrm{Cd}}$ equations are almost certain to change as high quality data are added to the core top calibration. The maximum value of 3 is particularly subject to modification. As mentioned above, Boyle's (1988a, 1992) estimate of 2.9 appears to be biased by samples from low- $\Delta \mathrm{CO}_{3}{ }^{2-}$ waters. Re-analysis of Boyle's data, combined with my data, imply a maximum value of $>3$ (Figure 2.11b); yet new boxcore data (E. Boyle, personal communication) suggest a value closer to 2.5. Again, much of this disagreement may be due to large $D_{\mathrm{Cd}}$ errors in low-Cd (Atlantic) waters. If the "true" maximum $D_{\mathrm{Cd}}$ is indeed $\sim 2.5$, the onset of the $\Delta \mathrm{CO}_{3}{ }^{2-}$ effect will be shifted towards more undersaturated waters. Boyle and Rosenthal (1996) suggested that the inflection is near $-15 \mu \mathrm{mol} \mathrm{kg}{ }^{-1}$ $\Delta \mathrm{CO}_{3}{ }^{2-}$, but this value seems to be extreme in light of the present data.

For the purposes of estimating $\Delta \mathrm{CO}_{3}{ }^{2-}$ from $\mathrm{Cd} / \mathrm{Ca}$ data (this chapter and Chapter $3)$, I will use the above preliminary $D_{\mathrm{Cd}}$ equations $(2.14,2.15)$. In Chapter 4 , however, where $\Delta \mathrm{CO}_{3}{ }^{2-}$ is less of an issue for $\mathrm{Cd} / \mathrm{Ca}$, I will revert to Boyle's (1992) depthdependent equations (2.9-2.11). Note also that the above equations do not necessarily apply to benthic foraminiferal taxa other than C. wuellerstorfi and Uvigerina. Specifically, it has been suggested that Nutallides umbonifera $\mathrm{Cd} / \mathrm{Ca}$ ratios are immune to the $\Delta \mathrm{CO}_{3}{ }^{2-}$ effect (Boyle and Rosenthal, 1996).

\section{$\triangle \mathrm{CO}_{3}{ }^{2-}$ effect in "live" benthic foraminifera}

The observed drops in apparent $D_{\mathrm{Zn}}$ and $D_{\mathrm{Cd}}$ in low- $\Delta \mathrm{CO}_{3}{ }^{2-}$ waters may be due to decreased incorporation of these trace metals during growth, or to post mortem preferential dissolution of trace metals over Ca (McCorkle et al., 1995; Boyle and Rosenthal, 1996). In the laboratory, neither $\mathrm{Zn}$ nor $\mathrm{Cd}$ is preferentially lost from benthic foraminiferal calcite as dissolution proceeds beyond the usual cleaning process (Figure 2.14; see also Boyle [1988] for Cd). This suggests that the measured trace metals are not localized on surfaces or in any other dissolution-prone phase. It is conceivable, however, that dissolution at the seafloor is more effective at selecting for trace metals than the rapid dissolution that occurs in the laboratory. Therefore a better test of the decreased 
incorporation vs. post mortem dissolution question is to look for the $\Delta \mathrm{CO}_{3}{ }^{2-}$ effect in living benthic foraminifera. This strategy has been used to infer that $\Delta \mathrm{CO}_{3}{ }^{2-}$ influences the fractionation of ${ }^{13} \mathrm{C}$ during benthic foraminiferal calcification (McCorkle et al., 1999).

A series of multicores were collected in 1998 in the region of the Brazil Basin $\left(\sim 26^{\circ}-30^{\circ} \mathrm{S}, \sim 43^{\circ}-47^{\circ} \mathrm{W}\right)$ over a depth range of about 500 to $4000 \mathrm{~m}$. Dissolved Si, P, $\Sigma \mathrm{CO}_{2}$, alkalinity, and salinity were measured in waters collected at each core site using a Niskin bottle mounted on the multicorer frame (D. McCorkle, Z. Mlodzinska, and G. Eisheid, unpublished data). The tops $(0-1 \mathrm{~cm})$ of these cores were preserved in a formalin solution and then stained with Rose Bengal to identify protoplasm (Corliss, 1985; Corliss and Emerson, 1990). Those foraminifera having at least one chamber filled with protoplasm were identified as "live", or more precisely, recently living. The rate of protoplasm decay, which must vary with such factors as bottom water dissolved $\mathrm{O}_{2}$ and organic matter rain rate, is not well constrained. Stained benthic foraminifera may therefore range from truly living when collected to having been dead for months or possibly years.

$\mathrm{Zn} / \mathrm{Ca}$ and $\mathrm{Cd} / \mathrm{Ca}$ were measured in unstained $\mathrm{C}$. wuellerstorfi from eight cores between 1604 and $3885 \mathrm{~m}$ depth, and in stained C. wuellerstorfi from just three cores (due to low stained abundances) between 3356 and $3885 \mathrm{~m}$ (Table 2.4). The $\Delta \mathrm{CO}_{3}{ }^{2-}$ values of the waters overlying these cores range from -3 to $47 \mu \mathrm{mol} \mathrm{kg}{ }^{-1}$ (Figure 2.15). Figure $2.16 \mathrm{a}$ shows the $\mathrm{Zn} / \mathrm{Ca}$ values predicted from bottom water $\mathrm{Si}$, using a constant $D_{\mathrm{Zn}}$ of 9 (exes) and $D_{\mathrm{Zn}}$ that varies with $\Delta \mathrm{CO}_{3}{ }^{2 *}$ according to Equations 2.6 and 2.7 (crosses). Unstained C. wuellerstorfi clearly show the $\Delta \mathrm{CO}_{3}{ }^{2-}$ effect in the four deepest cores. Stained specimens from 3356 and $3581 \mathrm{~m}$ have even lower $\mathrm{Zn} / \mathrm{Ca}$ values, and therefore also show the effect. The stained sample from $3885 \mathrm{~m}$ is by far the smallest (Table 2.4$)$ and a small contamination $(<2 \sigma$ of process blank $[\mathrm{Zn}]$ reproducibility) could explain the difference from its unstained counterpart. A plot of apparent $D_{\mathrm{Zn}} v s . \Delta \mathrm{CO}_{3}{ }^{2-}$ (Figure 2.16b) further illustrates the agreement between stained and unstained $C$. wuellerstorfi. 
$\mathrm{Cd} / \mathrm{Ca}$ values predicted from seawater $\mathrm{P}$ are shown in Figure $2.17 \mathrm{a}$, using $D_{\mathrm{Cd}}$ as a function of depth only (Equations 2.16, 2.17; exes) and as a function of both depth and $\Delta \mathrm{CO}_{3}{ }^{2 *}$ (Equations 2.14, 2.15; crosses). Unstained C. wuellerstorfi are close to predicted values, though the lack of severely undersaturated waters causes the $\Delta \mathrm{CO}_{3}{ }^{2-}$ effect to be obvious in only the deepest core. Stained individuals from 3356 and $3581 \mathrm{~m}$ are again even lower than unstained. It is curious that the stained sample from $3356 \mathrm{~m}$ is so depleted in $\mathrm{Cd}$, given that the $\Delta \mathrm{CO}_{3}{ }^{2 n}$ value at this site $\left(9 \mu \mathrm{mol} \mathrm{kg}^{-1}\right)$ predicts no effect. The $\mathrm{Cd} / \mathrm{Ca}$ of the stained sample from $3885 \mathrm{~m}$, although slightly higher than its unstained counterpart, is almost exactly as predicted from $\Delta \mathrm{CO}_{3}{ }^{2-}$. Thus the $\mathrm{Cd} / \mathrm{Ca}$ data, while not as compelling as the $\mathrm{Zn} / \mathrm{Ca}$ data, are consistent with a $\Delta \mathrm{CO}_{3}{ }^{2-}$ effect on living benthic foraminifera.

The above data support the theory (Boyle and Rosenthal, 1996; Elderfield et al. 1996) that the relationships between $\Delta \mathrm{CO}_{3}{ }^{2-}$ and the various apparent partition coefficients are set during growth. Unfortunately, the actual mechanisms of trace metal incorporation into foraminiferal calcite are not well understood. The zero'th order prediction of a metal's partition coefficient into calcite is based on an ideal solid solution:

$$
D_{\text {ideal }}=K_{\text {sp(calcite })} / K_{\text {sp(metal carbonate })}
$$

where $D_{\text {ideal }}$ is a true thermodynamic distribution coefficient, and $K_{\mathrm{sp}}$ is the solubility product for each solid at a given temperature and pressure. At $25^{\circ} \mathrm{C}$ and 1 bar pressure, the ideal distribution coefficients for $\mathrm{Zn}$ and $\mathrm{Cd}$ are $\sim 210$ and 680 , respectively (Davis et al., 1987; Zachara et al., 1988). In the real world, $D$ will also depend on the activities of the exchanging cations in solution and in the solid phase. For example, Crockett and Winchester's (1966) inorganic calcite precipitation experiments produced $\mathrm{Zn}$ partition coefficients of $\sim 6$ at $25^{\circ} \mathrm{C}$ and 1 bar pressure. Zachara et al. (1988) found that in the laboratory, $\mathrm{Zn}$ adsorption onto calcite decreases as $\mathrm{Ca}^{2+}$ activity increases and $\mathrm{CO}_{3}{ }^{2-}$ activity decreases, and they further suggested that $\mathrm{Ca}^{2+}$ and $\mathrm{CO}_{3}{ }^{2-}$ activities are influenced by calcite solubility. If increased solubility is linked to higher $\mathrm{Ca}^{2+}$ activities in the ocean, then this mechanism might be responsible for the link between foraminiferal $D$ and $\Delta \mathrm{CO}_{3}{ }^{2-}$. 
However, as noted by Morse and Bender (1990) and Elderfield et al. (1996), such inorganic considerations are of limited applicability because of the biological mediation of foraminiferal shell growth. Elderfield et al. (1996) proposed that trace metals are removed by Rayleigh distillation from an internal biomineralization reservoir with a constant fractionation factor, $\alpha$. If an infinitely small fraction of the reservoir is used up, the resulting $D$ (relative to the initial composition of the reservoir, which may or may not be the same as seawater) will be equal to $\alpha$ (Figure 2.18). As more of the reservoir is consumed, $D$ will approach 1 asymptotically. They further suggested that rapid calcification is accompanied by frequent flushing of the biomineralization reservoir, resulting in $D$ values close to $\alpha$. Thus slow calcification in undersaturated (low- $\Delta \mathrm{CO}_{3}{ }^{2-}$ ) waters would bring $D$ towards 1 . This model fits with the core top $\mathrm{Zn} / \mathrm{Ca}$ and $\mathrm{Cd} / \mathrm{Ca}$ data, where $\alpha$ is $>1$ and $D_{\mathrm{Zn}}$ and $D_{\mathrm{Cd}}$ decrease with decreasing $\Delta \mathrm{CO}_{3}{ }^{2-}$. It may also fit McCorkle et al.'s (1995) $\mathrm{Ba} / \mathrm{Ca}$ data if the biomineralization reservoir contains significantly less $\mathrm{Ba}$ than seawater, resulting in an $\alpha>1$ despite measured $D_{\mathrm{Ba}}$ values $<1$ (Lea and Boyle, 1989).

\section{Application to paleoceanography}

On glacial-interglacial timescales, a given core location may fall into one of three $\Delta \mathrm{CO}_{3}{ }^{2-}$ categories: (a) $\Delta \mathrm{CO}_{3}{ }^{2-}$ always remains above $\sim 25 \mu \mathrm{mol} \mathrm{kg}{ }^{-1}$, so neither $\mathrm{Zn} / \mathrm{Ca}$ nor $\mathrm{Cd} / \mathrm{Ca}$ are affected by saturation state; (b) $\Delta \mathrm{CO}_{3}{ }^{2-}$ falls below $\sim 25 \mu \mathrm{mol} \mathrm{kg}{ }^{-1}$ but remains above $\sim 5 \mu \mathrm{mol} \mathrm{kg}{ }^{-1}$, so only $\mathrm{Zn} / \mathrm{Ca}$ is affected; or (c) $\Delta \mathrm{CO}_{3}{ }^{2-}$ falls below $\sim 5 \mu \mathrm{mol} \mathrm{kg}{ }^{-1}$, and both $\mathrm{Zn} / \mathrm{Ca}$ and $\mathrm{Cd} / \mathrm{Ca}$ are affected. Calcite lysocline reconstructions suggest that LGM $\left[\mathrm{CO}_{3}{ }^{2-}\right]$ was on the order of 5 to $10 \mu \mathrm{mol} \mathrm{kg}{ }^{-1}$ higher than today in the deep Pacific and $\sim 10 \mu \mathrm{mol} \mathrm{kg}{ }^{-1}$ lower than today in the deep Atlantic (e.g., Farrell and Prell, 1989; Broecker, 1995). If these estimates are reasonably accurate, then case (a) would correspond to a relatively small portion of the world ocean, such as certain regions of the North Atlantic shallower than $\sim 3000 \mathrm{~m}$. Here $\mathrm{Zn} / \mathrm{Ca}$ and $\mathrm{Cd} / \mathrm{Ca}$ could be converted directly into inferred $\mathrm{Zn}_{\mathrm{W}}$ and $\mathrm{Cd}_{\mathrm{W}}$. Case (b) would be valid over a much larger region of 
the Atlantic, plus large portions of the Pacific shallower than $\sim 3000 \mathrm{~m}$. In such areas, $\mathrm{Cd}_{\mathrm{W}}$ (derived directly from $\mathrm{Cd} / \mathrm{Ca}$ ) could be used to estimate seawater dissolved $\mathrm{Zn}$ concentrations by making some assumptions about regional circulation. For example, dissolved $\mathrm{Cd}$ and $\mathrm{Zn}$ increase proportionally from south to north in the modern deep Pacific, so $\mathrm{Zn}$ can be predicted straightforwardly using $\mathrm{Cd}$. In the Atlantic, dissolved $\mathrm{Zn}$ and $\mathrm{Cd}$ would be related mainly by mixing of NADW (having one $\mathrm{Zn}$ :Cd end member ratio) with Southern Ocean waters (having another $\mathrm{Zn}: \mathrm{Cd}$ ratio). Once seawater $[\mathrm{Zn}]$ is predicted, it could be combined with observed foraminiferal $\mathrm{Zn} / \mathrm{Ca}$ to yield estimates of $\Delta \mathrm{CO}_{3}{ }^{2-}$. Paleo- $\Delta \mathrm{CO}_{3}{ }^{2-}$ values are easily converted to $\left[\mathrm{CO}_{3}{ }^{2-}\right]_{\text {in situ }}$ by calculating

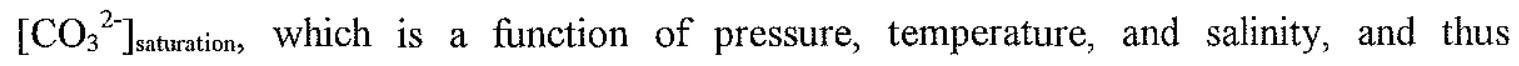
predicted to change little with time in the deep ocean.

New constraints on paleo- $\mathrm{CO}_{3}{ }^{2-}$ are important for understanding the cycling of $\mathrm{CO}_{2}$ between the atmosphere and ocean, and also the preservation of $\mathrm{CaCO}_{3}$ in marine sediments. Lysocline-based estimates could be inaccurate if significant glacial $\mathrm{CaCO}_{3}$ dissolution occurred within $\mathrm{CO}_{2}$-rich pore waters (e.g., Emerson and Bender, 1981; Archer and Maier-Reimer, 1994). Paleo-pH estimates based on benthic foraminiferal boron isotopes $\left(\delta^{11} \mathrm{~B}\right)$ imply that deep Pacific $\left[\mathrm{CO}_{3}{ }^{2-}\right]$ was actually $\sim 100 \mu \mathrm{mol} \mathrm{kg}{ }^{-1}$ higher than today (Sanyal et $a l$., 1995). This estimate is large enough to explain the entire LGM atmospheric $\mathrm{CO}_{2}$ drop via an increase in ocean alkalinity (Boyle, 1988b; Archer and Maier-Reimer, 1994; Sanyal et al., 1995). Model results of Sigman et al. (1998), however, imply that it would be difficult to separate the sedimentary lysocline from the calcite saturation horizon by the amount required by the data of Sanyal et al. (1995). $\mathrm{Zn} / \mathrm{Ca}$ and $\mathrm{Cd} / \mathrm{Ca}$ data presented below (Chapter 3 ) are also inconsistent with such a large $\left[\mathrm{CO}_{3}{ }^{2-}\right]$ increase. Recently, Broecker and Clark (in press) proposed that the percentage of $\mathrm{CaCO}_{3}>63 \mu \mathrm{m}$ can be used as a proxy for paleo- $\Delta \mathrm{CO}_{3}{ }^{2-}$, but this index is not immune to the complications of pore water dissolution.

$\Delta \mathrm{CO}_{3}{ }^{2-}$ case (c), which probably holds for much of the Pacific deeper than $\sim 3000$ $\mathrm{m}$, is the most complex situation because both $D_{\mathrm{Zn}}$ and $D_{\mathrm{Cd}}$ are affected. In theory, 
however, seawater $[\mathrm{Zn}],[\mathrm{Cd}]$, and $\Delta \mathrm{CO}_{3}{ }^{2-}$ can all be estimated by again making assumptions about regional circulation. This concept is illustrated in Figure 2.19 using a core top sample from the eastern tropical Pacific (KNR73-4PC). The possible pairs of bottom water dissolved $\mathrm{Zn}$ concentration and $\Delta \mathrm{CO}_{3}{ }^{2-n}$ that could produce the measured $C$. wuellerstorfi $\mathrm{Zn} / \mathrm{Ca}$ value are plotted as a continuous solid curve (using Equations 2.6 and 2.7). Similarly, the possible pairs of dissolved $\mathrm{Cd}$ and $\Delta \mathrm{CO}_{3}{ }^{2-}$ that could produce the measured $\mathrm{Cd} / \mathrm{Ca}$ value are plotted as a dotted curve (using Equations 2.12 and 2.13). The seawater $\mathrm{Zn}$ and $\mathrm{Cd}$ axes are scaled to each other using two tielines: Antarctic deep water entering the South Pacific with estimated $[\mathrm{Zn}]=5.7 \mathrm{nmol} \mathrm{kg}{ }^{-1}$ and $[\mathrm{Cd}]=0.59 \mathrm{nmol} \mathrm{\textrm {kg } ^ { - 1 }}$, and northeast Pacific deep water with estimated $[\mathrm{Zn}]=9.5 \mathrm{nmol} \mathrm{\textrm {kg } ^ { - 1 }}$ and $[\mathrm{Cd}]=0.75$ nmol kg-1 (Broecker et al., 1982; Boyle, 1988a). Since eastern tropical Pacific deep water can be thought of as an intermediate between these two end members, the point where the $\mathrm{Zn} / \mathrm{Ca}$ and $\mathrm{Cd} / \mathrm{Ca}$ curves intersect corresponds to the inferred trace metal concentrations and $\Delta \mathrm{CO}_{3}{ }^{2-}$ above KNR73-4PC. This model assumes that despite the scatter observed in Figure $2.11, C$. wuellerstorfi and Uvigerina are relatively precise recorders of bottom water $\mathrm{Cd}$ and $\Delta \mathrm{CO}_{3}{ }^{2-}$ levels. In reality, it is likely that the limited reproducibility of benthic foraminiferal data would result in significant errors, especially for inferred seawater $\mathrm{Zn}$ and $\mathrm{Cd}$ concentrations. $\Delta \mathrm{CO}_{3}{ }^{2-}$ would be less subject to error because it is related to $\mathrm{Zn} / \mathrm{Ca}$ and $\mathrm{Cd} / \mathrm{Ca}$ through partition coefficients (i.e., large changes in $\mathrm{Zn} / \mathrm{Ca}$ and $\mathrm{Cd} / \mathrm{Ca}$ correspond to relatively small changes in $\Delta \mathrm{CO}_{3}{ }^{2-}$ ).

The initial obstacle to applying the methods proposed for cases (b) and (c) is that end member trace metal concentrations during the past may have been different from today because of changes in global oceanic inventories or circulation. Although the oceanic residence time of dissolved $\mathrm{Zn}$ is poorly constrained, it is probably between a few thousand (Bruland et al., 1994) and a few tens of thousands (Shiller and Boyle, 1985) of years, so glacial-interglacial inventory changes cannot be ruled out (see Chapter 3 for further discussion). If such variations existed during the past they would become apparent after many cores are analyzed using a synoptic strategy. Inventory changes would be 
distinguishable from $\Delta \mathrm{CO}_{3}{ }^{2-}$ changes because their spatial influences on benthic foraminifera would be very different. Eventually whole-ocean corrections might be applied, such as that used for $\delta^{13} \mathrm{C}$ during the LGM (Duplessy et al., 1988; Boyle, 1992). Only then could reliable paleo- $\Delta \mathrm{CO}_{3}{ }^{2 \mu}$ and paleo- $\left[\mathrm{CO}_{3}{ }^{2-}\right]$ estimates be made. Even without a detailed assessment of the LGM oceanic $\mathrm{Zn}$ inventory, a $\mathrm{CO}_{3}{ }^{2-}$ increase of the magnitude proposed by Sanyal et al. (1995) $\left(\sim 100 \mu \mathrm{mol} \mathrm{kg}^{-1}\right)$ should be easily recognizable using paired $\mathrm{Zn} / \mathrm{Ca}$ and $\mathrm{Cd} / \mathrm{Ca}$ measurements (see Chapter 3).

\section{$\mathrm{Zn} / \mathrm{Ca}$ in other benthic foraminiferal species}

While the available data suggest that $\mathrm{Zn}$ behaves similarly in $C$. wuellerstorfi and Uvigerina spp., there are apparent differences in N. umbonifera, C. kullenbergi, and Hoeglundina elegans (Table 2.2). N. umbonifera $\mathrm{Zn} / \mathrm{Ca}$ ratios tend to be significantly lower than coexisting $C$. wuellerstorfi and Uvigerina values (Figure 2.20). Because the available data are limited to a relatively narrow range of seawater $\Delta \mathrm{CO}_{3}{ }^{2-}$ values, it is not clear whether this is due to a different $D_{\mathrm{Zn}}: \Delta \mathrm{CO}_{3}{ }^{2-}$ relationship, or simply to a lower $D_{\mathrm{Zn}}$ that is unrelated to $\Delta \mathrm{CO}_{3}{ }^{2-}$ (Figure 2.21). The data are consistent with a constant $\mathrm{Zn}$ partition coefficient of $\sim 4.5$. Boyle and Rosenthal (1996) noted that $N$. umbonifera $\mathrm{Cd} / \mathrm{Ca}$ is unaffected by undersaturation with respect to calcite. $\mathrm{My} \mathrm{Cd} / \mathrm{Ca}$ data show no obvious $\Delta \mathrm{CO}_{3}{ }^{2-}$ effect, and are thus consistent with a constant $D_{\mathrm{Cd}}$ (deeper than $3000 \mathrm{~m}$ ) of $\sim 2$ to 2.5 (Figure 2.22). If $N$. umbonifera partition coefficients are indeed unaffected by $\Delta \mathrm{CO}_{3}{ }^{2-}$, there is hope of using this species to separate the seawater trace metal and $\Delta \mathrm{CO}_{3}{ }^{2-}$ signals in C. wuellerstorfi and Uvigerina $\mathrm{Zn} / \mathrm{Ca}$ and $\mathrm{Cd} / \mathrm{Ca}$ data.

C. kullenbergi (here taken to include C. pachyderma, following the practice of Boyle [1992]) was analyzed in only four cores. $\mathrm{Zn} / \mathrm{Ca}$ values are very high relative to other taxa (7.4-9.5 $\mu \mathrm{mol} \mathrm{mol}^{-1}$ ) (Figure 2.23a). This could be due to either contamination or to very high partition coefficients $(43 \pm 11)$. H. elegans is expected to be different from other benthic foraminifera because it is made of aragonite (orthorhombic $\mathrm{CaCO}_{3}$ ) rather than calcite (hexagonal $\mathrm{CaCO}_{3}$ ). Boyle et al. (1995) found that the $\mathrm{Cd}$ partition coefficient 
into $H$. elegans is $\sim 1$, apparently independent of water depth, in good agreement with my data $(1.1 \pm 0.2)$. The available $\mathrm{Zn} / \mathrm{Ca}$ data give a $D_{\mathrm{Zn}}$ of $1.7 \pm 0.8$, but there is only one sample from waters with $[\mathrm{Zn}]>4 \mathrm{nmol} \mathrm{kg}^{-1}$ (Figure 2.23b). There are not enough $C$. kullenbergi or H. elegans data at this time to evaluate the potential relationships between $D_{\mathrm{Zn}}$ and $\Delta \mathrm{CO}_{3}{ }^{2-}$.

\section{Conclusions}

$\mathrm{Zn} / \mathrm{Ca}$ ratios in C. wuellerstorfi and Uvigerina spp. are controlled by bottom water dissolved $\mathrm{Zn}$ concentrations and by saturation state with respect to calcite. Bottom water $\mathrm{Zn}$ concentrations are, in turn, mainly controlled by deep circulation and the global oceanic $\mathrm{Zn}$ inventory. Benthic foraminiferal $\mathrm{Cd} / \mathrm{Ca}$ and $\mathrm{Ba} / \mathrm{Ca}$ are influenced by similar factors (Hester and Boyle, 1982; Boyle, 1986; Lea and Boyle, 1989, 1990; McCorkle et al., 1995), while $\delta^{13} \mathrm{C}$ and $\mathrm{Ba} / \mathrm{Ca}$ are subject to additional artifacts that complicate their interpretation (Charles et al., 1993; Mackensen et al., 1993; Martin and Lea, 1998). These various factors can be best separated by employing a multi-tracer approach. With the addition of $\mathrm{Zn} / \mathrm{Ca}$, not only can we decipher climatically-important deep water circulation changes, but we can examine changes in bottom water carbonate chemistry. The latter are vitally important to our understanding of the global carbon cycle and atmospheric $\mathrm{CO}_{2}$ levels. 


\section{References}

Archer, D., and E. Maier-Reimer, Effect of deep-sea sedimentary calcite preservation on atmospheric $\mathrm{CO}_{2}$ concentration, Nature, 367, 260-263, 1994.

Bainbridge, A. E., GEOSECS Atlantic Expedition, Vol. 1, Hydrographic Data, U. S. Government Printing Office, Washington, 1981.

Berger, W. H., T. Bickert, H. Schmidt, and G. Wefer, Quaternary oxygen isotope record of pelagic foraminifers: Site 806, Ontong Java Plateau, Proc. Ocean Drilling Program, Sci. Results, 130, 381-395, 1993.

Boyle, E. A., Cadmium, zinc, copper, and barium in foraminifera tests, Earth Planet. Sci. Lett., 53, 11-35, 1981.

Boyle, E. A., Paired carbon isotope and cadmium data from benthic foraminifera: Implications for changes in oceanic phosphorous, oceanic circulation, and atmospheric carbon dioxide, Geochim. Cosmochim. Acta, 50, 265-276, 1986.

Boyle, E. A., Cadmium: Chemical tracer of deepwater paleoceanography, Paleoceanography, 3, 471-489, 1988a.

Boyle, E. A., The role of vertical chemical fractionation in controlling Late Quaternary atmospheric carbon dioxide, J. Geophys. Res., 93, 15701-15714, 1988 b.

Boyle, E. A., Cadmium and $\delta^{13} \mathrm{C}$ paleochemical ocean distributions during the Stage 2 glacial maximum, Annu. Rev. Earth Planet. Sci., 20, 245-287, 1992.

Boyle, E. A., and L. D. Keigwin, Deep circulation of the North Atlantic over the last 200,000 years: Geochemical evidence, Science, 218, 784-787, 1982.

Boyle, E. A., and L. D. Keigwin, Comparison of Atlantic and Pacific paleochemical records for the last 215,000 years: changes in deep ocean circulation and chemical inventories, Earth Planet. Sci. Lett., 76, 135-150, 1985/86.

Boyle, E. A., and L. D. Keigwin, North Atlantic thermohaline circulation during the last 20,000 years linked to high latitude surface temperature, Nature, 330, 35-40, 1987.

Boyle, E. A., and Y. Rosenthal, Chemical hydrography of the South Atlantic during the last glacial maximum: $\mathrm{Cd}$ vs. $\delta^{13} \mathrm{C}$, in The South Atlantic: Present and Past Circulation, edited by G. Wefer et al., pp. 423-443, Springer-Verlag, Berlin, 1996. 
Boyle, E. A., L. Labeyrie, and J.-C. Duplessy, Calcitic foraminiferal data confirmed by cadmium in aragonitic Hoeglundina: Application to the last glacial maximum in the northern Indian Ocean, Paleoceanography, 10, 881-900, 1995.

Broecker, W. S., The Glacial World According to Wally, Eldigio Press, Palisades, 1995.

Broecker, W. S., and E. Clark, $\mathrm{CaCO}_{3}$ size distribution: A paleo carbonate ion proxy?, Paleoceanography, in press.

Broecker, W. S., D. W. Spencer, and H. Craig, GEOSECS Pacific Expedition, Vol. 3, Hydrographic Data, U. S. Government Printing Office, Washington, 1982.

Bruland, K. W., Oceanographic distributions of cadmium, zinc, nickel, and copper in the North Pacific, Earth Planet. Sci. Lett., 47, 176-198, 1980.

Bruland, K. W., and R. P. Franks, Mn, Ni, Cu, $\mathrm{Zn}$ and $\mathrm{Cd}$ in the western North Atlantic, in Trace Metals in Seawater, NATO Conf. Ser. 4, Marine Science Vol. 9, pp. 395-414, Plenum, 1983.

Bruland, K. W., G. A. Knauer, and J. H. Martin, Zinc in north-east Pacific water, Nature, 271, 741-743, 1978.

Bruland, K. W., J. R. Donat, and D. A. Hutchins, Interactive influences of bioactive trace metals on biological production in oceanic waters, Limnol. Oceanogr., 36, $1555-1577,1991$.

Bruland, K. W., K. J. Orians, and J. P. Cowen, Reactive trace metals in the stratified central North Pacific, Geochim. Cosmochim. Acta, 58, 3171-3182, 1994.

Charles, C. D., J. D. Wright, and R. G. Fairbanks, Thermodynamic influences on the marine carbon isotope record, Paleoceanography, 8, 691-697, 1993.

Collier, R., and J. Edmond, The trace element geochemistry of marine biogenic particulate matter, Prog. Oceanogr., 13, 113-199, 1984.

Corliss, B. H., Microhabitats of benthic foraminifera within deep-sea sediments, Nature, $314,435-438,1985$.

Corliss, B. H., and S. R. Emerson, Distribution of Rose Bengal stained deep-sea benthic foraminifera from the Nova Scotian continental margin and Gulf of Maine, Deep-Sea Research, 37, 381-400, 1990. 
Crockett, J. H., and J. W. Winchester, Coprecipitation of zinc with calcium carbonate, Geochim. Cosmochim. Acta, 30, 1093-1109, 1966.

Curry, W. B., and G. P. Lohmann, Carbon isotopic changes in benthic foraminifera from the western South Atlantic: Reconstruction of glacial abyssal circulation patterns, Quat. Res., 18, 218-235, 1982.

Curry, W. B., and G. P. Lohmann, Reduced advection into Atlantic Ocean deep eastern basins during last glaciation maximum, Nature, 306, 577-580, 1983.

Curry, W. B., and G. P. Lohmann, Reconstructing past particle fluxes in the tropical Atlantic Ocean, Paleoceanography, 5, 487-505, 1990.

Curry, W. B., J. C. Duplessy, L. D. Labeyrie, and N. J. Shackleton, Changes in the distribution of $\delta^{13} \mathrm{C}$ of deep water $\Sigma \mathrm{CO}_{2}$ between the last glaciation and the Holocene, Paleoceanography, 3, 317-341, 1988.

Curry, W. B., T. M. Marchitto, J. F. McManus, D. W. Oppo, and K. L. Laarkamp, Millennial-scale changes in ventilation of the thermocline, intermediate, and deep waters of the glacial North Atlantic, in Mechanisms of Global Climate Change at Millennial Time Scales, edited by P. U. Clark and R. S. Webb, AGU Monograph, in press.

Davis, J. A., C. C. Fuller, and A. D. Cook, A model for trace metal sorption processes at the calcite surface: Adsorption of $\mathrm{Cd}^{2+}$ and subsequent solid solution formation, Geochim. Cosmochim. Acta, 51, 1477-1490, 1987.

Dickson, A. G., and F. J. Millero, A comparison of the equilibrium constants for the dissociation of carbonic acid in seawater media, Deep Sea Res., 34, 1733-1743, 1987.

Droxler, A. W., G. A. Haddad, D. A. Mucciarone, and J. L. Cullen, PliocenePleistocene aragonite cyclic variations in Holes 714A and 716B (the Maldives) compared with Hole $633 \mathrm{~A}$ (the Bahamas): Records of climate-induced $\mathrm{CaCO}_{3}$ preservation at intermediate water depths, Proc. Ocean Drilling Program, Sci. Results, 115, 539-577, 1990.

Duplessy, J.-C., N. J. Shackleton, R. G. Fairbanks, L. Labeyrie, D. Oppo, and N. Kallel, Deepwater source variations during the last climatic cycle and their impact on the global deepwater circulation, Paleoceanography, 3, 343-360, 1988. 
Elderfield, H., C. J. Bertram, and J. Erez, A biomineralization model for the incorporation of trace elements into foraminiferal calcium carbonate, Earth Planet. Sci. Lett., 142, 409-423, 1996.

Ellwood, M. J., and K. A. Hunter, Diatoms as markers of past zinc levels, New Zealand Geochem. Grp. Newslett., 99, 11, 1996.

Emerson, S., and M. L. Bender, Carbon fluxes at the sediment water interface of the deep sea: Calcium carbonate preservation, J. Mar. Res., 39, 139-162, 1981.

Farrell, J. W., and W. L. Prell, Climate change and $\mathrm{CaCO}_{3}$ preservation: An 800,000 year bathymetric reconstruction from the central equatorial Pacific Ocean, Paleoceanography, 4, 447-466, 1989.

Graham, D. W., B. H. Corliss, M. L. Bender, and L. D. Keigwin, Carbon and oxygen isotopic disequilibria of recent deep-sea benthic foraminifera, Mar. Micropaleontology, 6, 483-497, 1981.

Hester, K., and E. A. Boyle, Water chemistry control of the Cd content of benthic foraminifera, Nature, 298, 260-261, 1982.

Jones, G. A., D. A. Johnson, and W. B. Curry, High-resolution stratigraphy in Late Pleistocene/Holocene sediments of the Vema Channel, Mar. Geol., 58, 59-87, 1984.

Keigwin, L. D., Stable isotope stratigraphy and chronology of the Upper Quaternary section at Site 883, Detroit Seamount, Proc. Ocean Drilling Program, Sci. Results; $145,257-264,1995$.

Keigwin, L. D., Glacial-age hydrography of the far northwest Pacific Ocean, Paleoceanography, 13, 323-339, 1998.

Lea, D. W., and E. A. Boyle, Barium content of benthic foraminifera controlled by bottom-water composition, Nature, 338, 751-753, 1989.

Lea, D. W., and E. A. Boyle, Foraminiferal reconstructions of barium distributions in water masses of the glacial oceans, Paleoceanography, 5, 719-742, 1990.

Lynch-Stieglitz, J., and R. G. Fairbanks, A conservative tracer for glacial ocean circulation from carbon isotope and palaeo-nutrient measurements in benthic foraminifera, Nature, 369, 308-310, 1994.

Mackensen, A., H.-W. Hubberten, T. Bickert, G. Fischer, and D. K. Fütterer, The $\delta^{13} \mathrm{C}$ in benthic foraminiferal tests of Fontbotia wuellerstorfi (Schwager) relative to the $\delta^{13} \mathrm{C}$ 
of dissolved inorganic carbon in Southern Ocean deep water: Implications for glacial ocean circulation models, Paleoceanography, 8, 587-610, 1993.

Martin, J. H., R. M. Gordon, S. Fitzwater, and W. W. Broenkow, VERTEX: phytoplankton/iron studies in the Gulf of Alaska, Deep-Sea Res., 36, 649-680, 1989.

Martin, J. H., R. M. Gordon, and S. E. Fitzwater, Iron in Antarctic waters, Nature, $345,156-158,1990$.

Martin, P. A., and D. W. Lea, Comparison of water mass changes in the deep tropical Atlantic derived from $\mathrm{Cd} / \mathrm{Ca}$ and carbon isotope records: Implications for changing Ba composition of deep Atlantic water masses, Paleoceanography, 13, 572-585, 1998.

McCorkle, D. C., P. A. Martin, D. W. Lea, and G. P. Klinkhammer, Evidence of a dissolution effect on benthic foraminiferal shell chemistry: $\delta^{13} \mathrm{C}, \mathrm{Cd} / \mathrm{Ca}, \mathrm{Ba} / \mathrm{Ca}$, and $\mathrm{Sr} / \mathrm{Ca}$ results from the Ontong Java Plateau, Paleoceanography, 10, 699-714, 1995.

McCorkle, D. M., P. A. Martin, B. H. Corliss, D. W. Lea, J. McManus, and G. P. Klinkhammer, Calibration studies of benthic foraminiferal isotopic and elemental composition, Eos, Transactions, AGU, 80, S172, 1999.

Millero, F. J., The thermodynamics of the carbonate system in seawater, Geochim. Cosmochim. Acta, 43, 1651-1661, 1979.

Morel, F. M. M., J. R. Reinfelder, S. B. Roberts, C. P. Chamberlain, J. G. Lee, and D. Yee, Zinc and carbon co-limitation of marine phytoplankton, Nature, 369, 740$742,1994$.

Morse, J. W., and M. L. Bender, Partition coefficients in calcite: Examination of factors influencing the validity of experimental results and their application to natural systems, Chem. Geol., 82, 265-277, 1990.

Mucci, A., The solubility of calcite and aragonite in seawater at various salinities, temperatures, and one atmospheric total pressure, Amer. J. Sci., 283, 780-799, 1983.

Oppo, D. W., and S. J. Lehman, Mid-depth circulation of the subpolar North Atlantic during the Last Glacial Maximum, Science, 259, 1148-1152, 1993.

Ravelo, A. C., and N. J. Shackleton, Evidence for surface-water circulation changes at Site 851 in the eastern tropical Pacific Ocean, Proc. Ocean Drilling Program, Sci. Results, 138, 503-514, 1995. 
Rosenthal, Y., Late Quaternary paleochemistry of the Southern Ocean: Evidence from cadmium variability in sediments and foraminifera, Ph.D. thesis, Mass. Inst. of Technol./Woods Hole Oceanogr. Inst. Joint Program in Oceanogr., Cambridge, MA, 1994.

Sabine, C. L., et al., Anthropogenic $\mathrm{CO}_{2}$ inventory of the Indian Ocean, Glob. Biogeochem. Cycles, 13, 179-198, 1999.

Sanyal, A., N. G. Hemming, G. N. Hanson, and W. S. Broecker, Evidence for a higher pH in the glacial ocean from boron isotopes in foraminifera, Nature, 373, 234-236, 1995.

Sarnthein, M., and R. Tiedemann, Toward a high-resolution stable isotope stratigraphy of the last 3.4 million years: Sites 658 and 659 off northwest Africa, Proc. Ocean Drilling Program, Sci. Results, I08, 167-185, 1989.

Sarnthein, M., et al., Changes in east Atlantic deepwater circulation over the last 30,000 years: Eight time slice reconstructions, Paleoceanography, 9, 209-267, 1994.

Shackleton, N. J., and M. A. Hall, Oxygen and carbon isotope stratigraphy of Deep Sea Drilling Project Hole 552A: Plio-Pleistocene glacial history, Init. Rep. Deep Sea Drilling Program, 81, 599-609, 1984.

Shiller, A. M, and E. Boyle, Dissolved zinc in rivers, Nature, 317, 49-52, 1985.

Sigman, D. M., D. C. McCorkle, and W. R. Martin, The calcite lysocline as a constraint on glacial/interglacial low-latitude production changes, Glob. Biogeochem. Cycles, 12, 409-427, 1998.

Sunda, W. G., and S. A. Huntsman, Cobalt and zinc interreplacement in marine phytoplankton: Biological and geochemical implications, Limnol. Oceanogr., 40, $1404-1417,1995$.

UNESCO, Thermodynamics of the carbon dioxide system in seawater, UNESCO Tech. Papers Mar. Sci., 51, 1987.

Weiss, R. F., W. S. Broecker, H Craig, and D. W. Spencer, GEOSECS Indian Ocean Expedition, Vol. 5, Hydrographic Data, U. S. Government Printing Office, Washington, 1983.

Zachara, J. M., J. A. Kittrick, and J. B. Harsh, The mechanism of $\mathrm{Zn}^{2+}$ adsorption on calcite, Geochim. Cosmochim. Acta, 52, 2281-2291, 1988. 


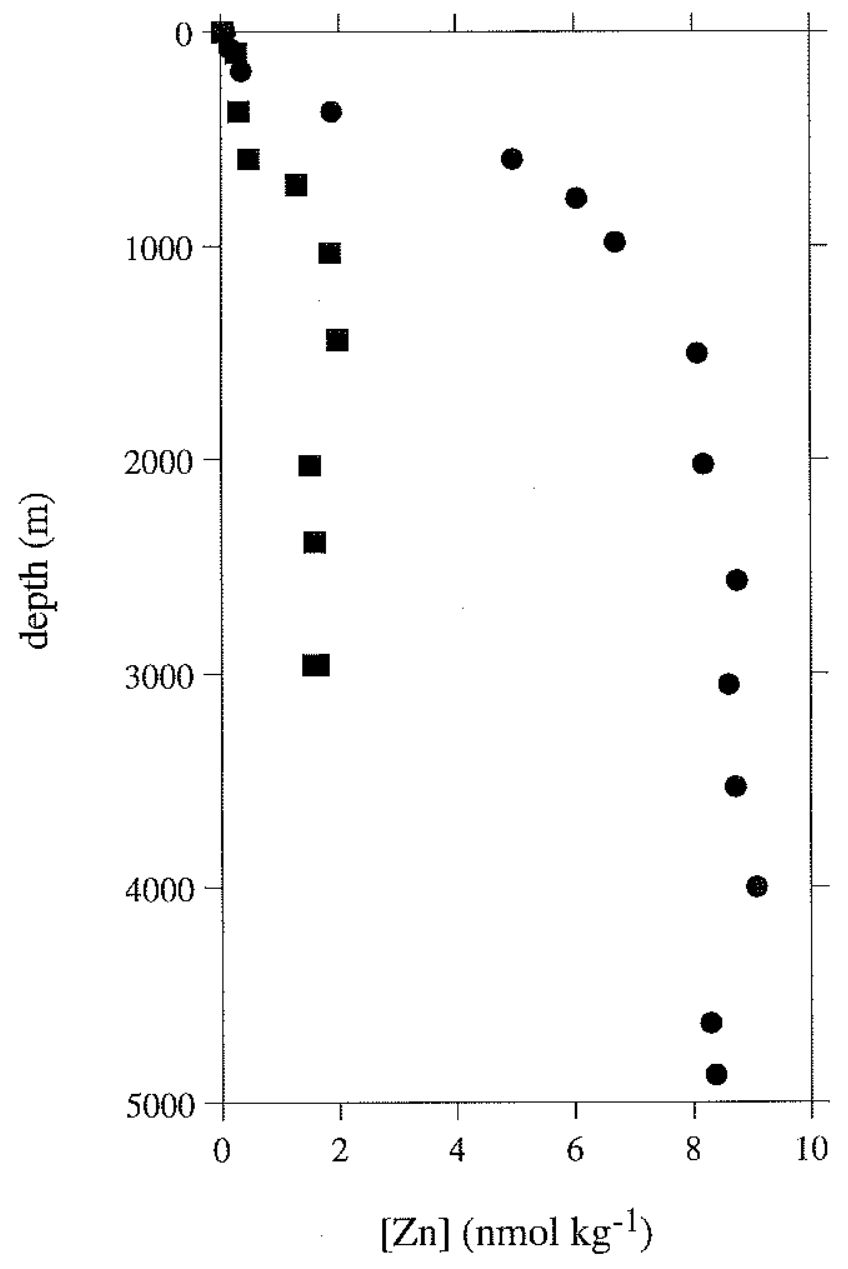

Figure 2.1. Vertical profiles of dissolved $\mathrm{Zn}$ in the North Atlantic (squares; $34^{\circ} \mathrm{N}$, $66^{\circ} \mathrm{W}$; Bruland and Franks, 1983) and North Pacific (circles; $33^{\circ} \mathrm{N}, 145^{\circ} \mathrm{W}$; Bruland, $1980)$. 


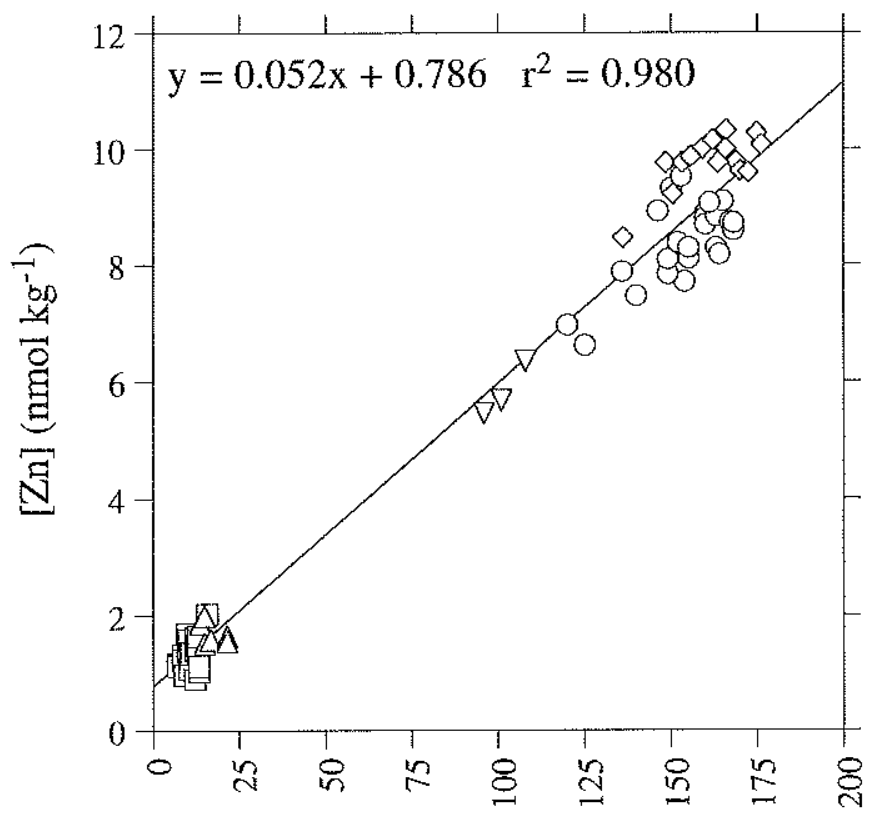

$[\mathrm{Si}]\left(\mu \mathrm{mol} \mathrm{kg}{ }^{-1}\right)$

Figure 2.2. Modern relationship between dissolved $\mathrm{Zn}$ and dissolved $\mathrm{Si}$ concentrations in seawater deeper than $1000 \mathrm{~m}$. Data are from $54^{\circ}-68^{\circ} \mathrm{N}$ (squares; Yeats and Dalziel, personal communication), $34^{\circ} \mathrm{N}$ (triangles; Bruland and Franks, 1983 ), and $61^{\circ} \mathrm{S}$ (inverted triangles; Martin et al., 1990) in the Atlantic; and from $33^{\circ}-37^{\circ} \mathrm{N}$ (circles; Bruland et al., 1978; Bruland, 1980) and $40^{\circ}-56^{\circ} \mathrm{N}$ (diamonds; Martin et al., 1989) in the Pacific. 
Figure 2.3. (next page) Modern dissolved $\mathrm{Zn}$ (top) and $\mathrm{Cd}$ (bottom) concentrations in the western Atlantic Ocean, estimated from GEOSECS dissolved $\mathrm{Si}$ and $\mathrm{P}$ measurements (Bainbridge, 1981), respectively. 


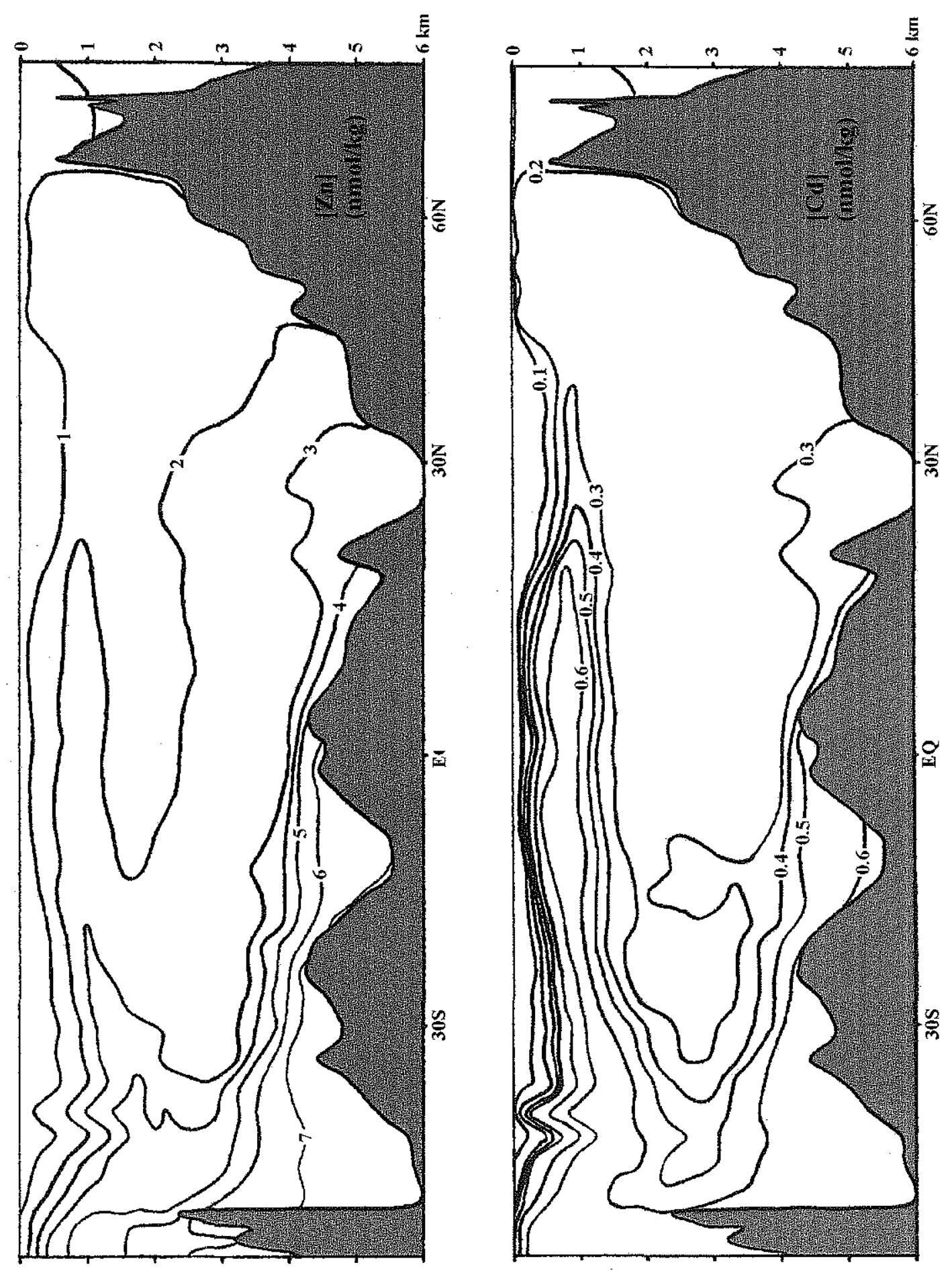




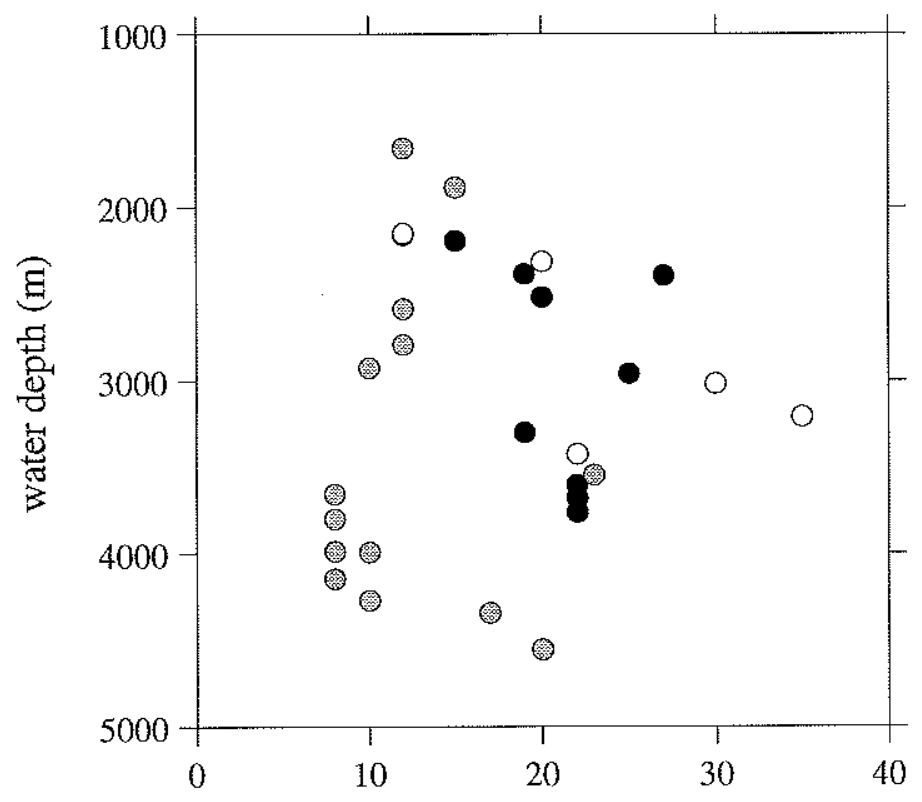

Holocene thickness $(\mathrm{cm})$

Figure 2.4. Estimated lengths of Holocene sections of cores used in the core top calibration. Cores are from the North Atlantic (open), tropical and South Atlantic (shaded), and Indian and Pacific (filled). Two additional cores from $1849 \mathrm{~m}$ and 2263 $\mathrm{m}$ in the North Atlantic plot off the scale $(>100 \mathrm{~cm}$ Holocene). See Table 2.1 for references. 


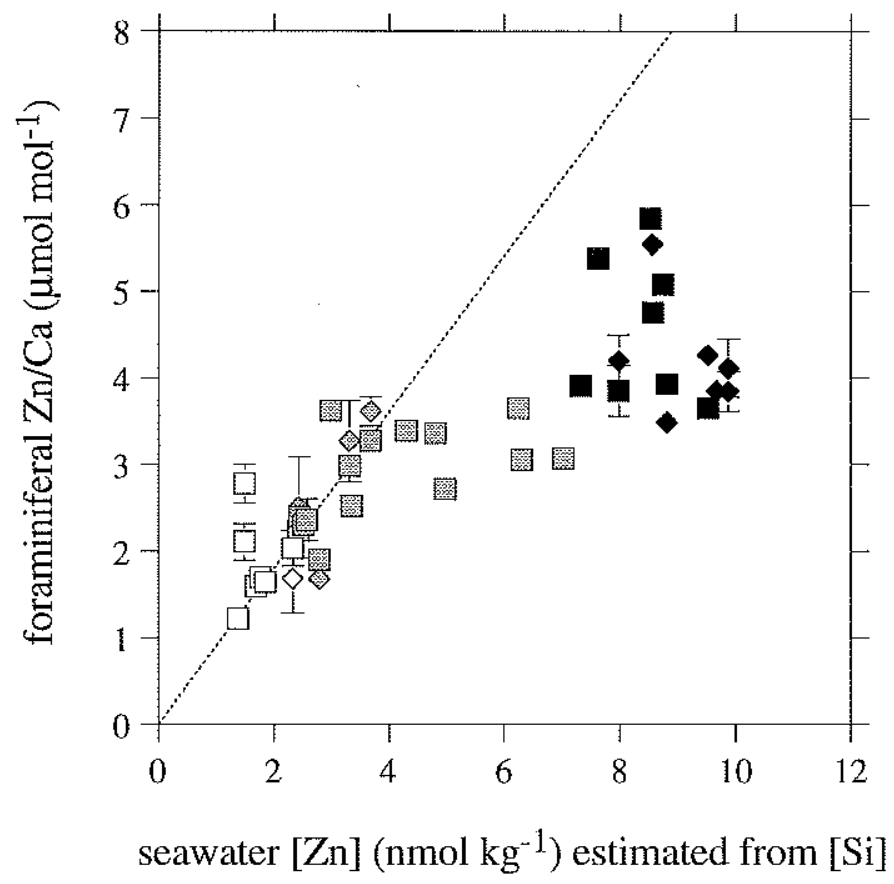

Figure 2.5. $\mathrm{Zn} / \mathrm{Ca}$ ratios in Holocene benthic foraminifera $C$. wuellerstorfi (squares) and Uvigerina spp. (diamonds), ys. bottom water dissolved $\mathrm{Zn}$ concentrations estimated from nearby GEOSECS dissolved Si measurements and the global deep water $\mathrm{Zn}$ :Si relationship shown in Figure 2.2. Core tops are from the North Atlantic (open symbols), the tropical and South Atlantic (shaded), and the Indian and Pacific (filled). Each symbol is a mean of up to three measurements, and error bars are $+/-1 \sigma$ of replicates. Dotted line represents the relationship for waters in which $D_{\mathrm{Zn}}$ appears to be unaffected by $\Delta \mathrm{CO}_{3}{ }^{2-}$, i.e., $D_{\mathrm{Zn}}=9$. 


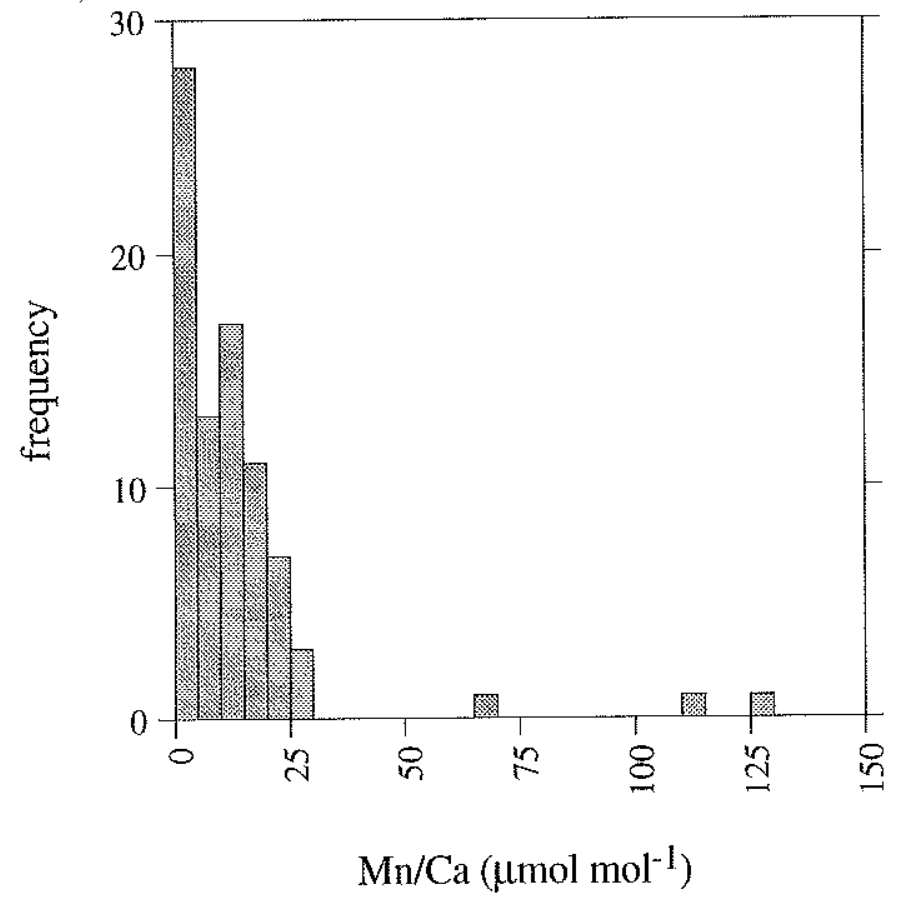

Figure 2.6. Histogram of $\mathrm{Mn} / \mathrm{Ca}$ atios in the $C$. wuellerstorfi and Uvigerina samples in the core top calibration. Two highest values are from $C$. wuellerstorfi in core AII54-9-5. 


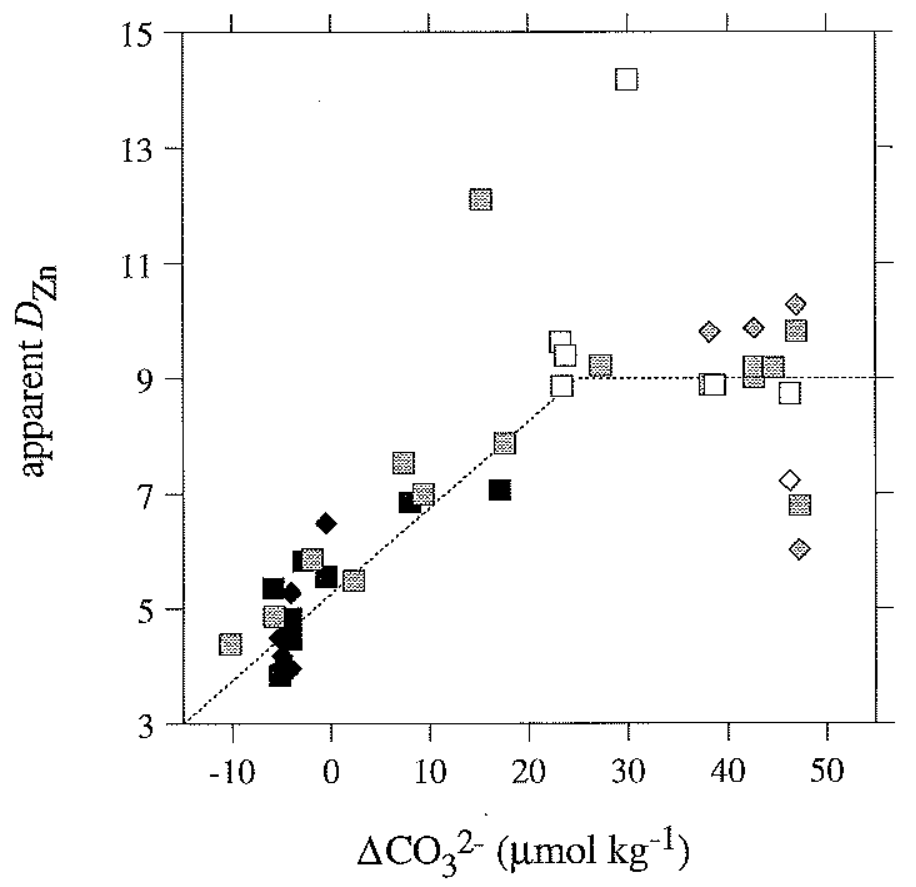

Figure 2.7. Apparent partition coefficients for $\mathrm{Zn}$ into benthic foraminiferal calcite $\left(D_{\mathrm{Zn}}\right)$ vs. bottom water saturation state with respect to calcite $\left(\Delta \mathrm{CO}_{3}{ }^{2-}\right)$. Squares are $C$. wuellerstorfi and diamonds are Uvigerina spp. Core tops are from the North Atlantic (open symbols), the tropical and South Atlantic (shaded), and the Indian and Pacific (filled). Dotted lines represent a simple two-part linear relationship (see text), not necessarily the best fit to the data. Note that one datum from the North Atlantic plots off the scale $\left(D_{\mathrm{Zn}}=19, \Delta \mathrm{CO}_{3}^{2-}=29\right)$. 

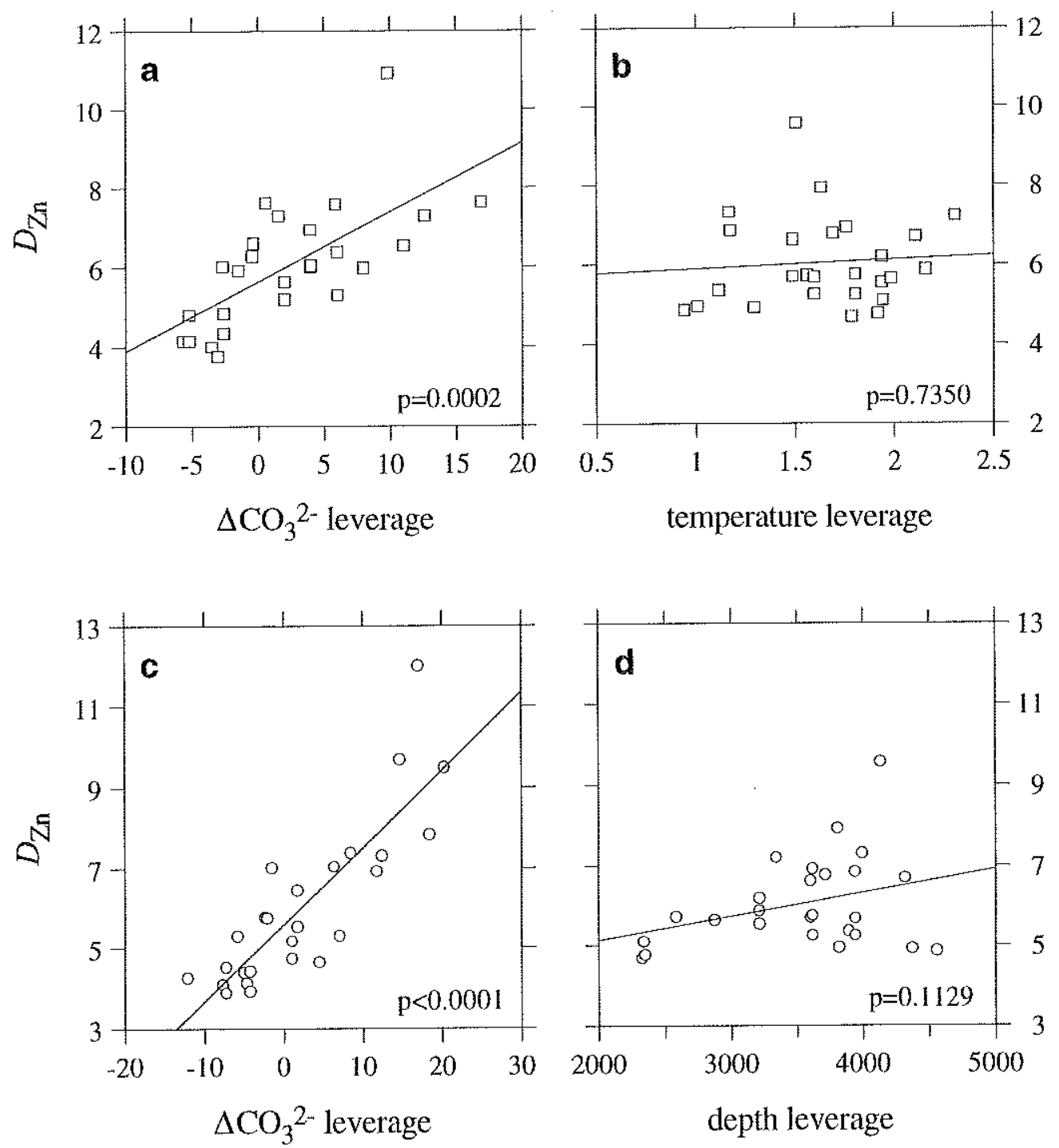

Figure 2.8. Results of two models to predict benthic foraminiferal $D_{\mathrm{Zn}}$ in waters with $\Delta \mathrm{CO}_{3}{ }^{2-}<25 \mu \mathrm{mol} \mathrm{mol}^{-1}$. In the first model, the effects are $\Delta \mathrm{CO}_{3}{ }^{2-}$ (a) and temperature (b). In the second, the effects are $\Delta \mathrm{CO}_{3}{ }^{2-}$ (c) and water depth (d). Plots show the leverage of each effect in the two models; a strong correlation suggests that the given variable is important. P-values represent the probability that a higher correlation could occur by chance. Over the range of these data, temperature and depth do not appear to be significant factors in controlling $D_{\mathrm{Zn}}$. 


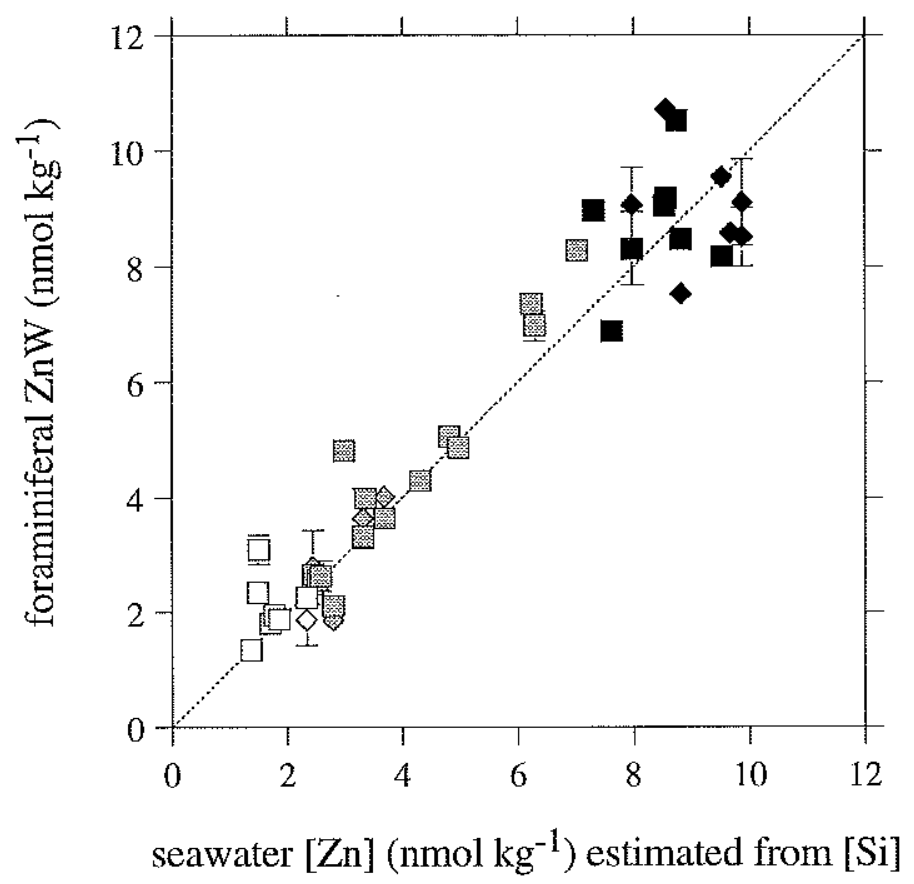

Figure 2.9. Benthic foraminiferal $\mathrm{Zn}_{\mathrm{W}} v$ s. seawater dissolved $\mathrm{Zn}$ estimated from GEOSECS Si. Squares are C. wuellerstorfi and diamonds are Uvigerina spp. Core tops are from the North Atlantic (open symbols), the tropical and South Atlantic (shaded), and the Indian and Pacific (filled). $\mathrm{Zn}_{\mathrm{W}}$ was calculated using $D_{\mathrm{Zn}}$ values derived from the two-part linear relationship shown in Figure 2.7. Dotted line is the 1:1 line. 


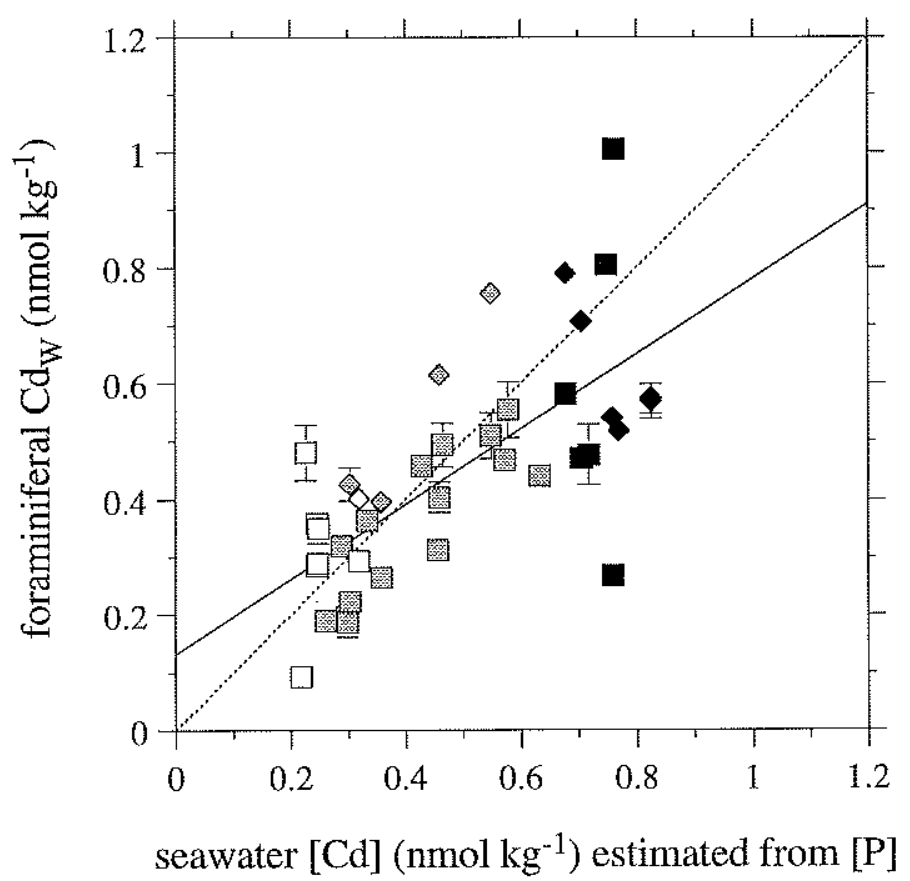

Figure 2.10. Benthic foraminiferal $\mathrm{Cd}_{\mathrm{W}}$, calculated from $\mathrm{Cd} / \mathrm{Ca}$ using the depth-dependent partition coefficients of Boyle (1992), vs. bottom water dissolved Cd concentrations estimated from nearest GEOSECS dissolved P. Squares are $C$. wuellerstorfi and diamonds are Uvigerina spp. Core tops are from the North Atlantic (open symbols), the tropical and South Atlantic (shaded), and the Indian and Pacific (filled). Dotted line is the 1:1 line, and solid line is the best fit $\left(\mathrm{r}^{2}=0.48\right)$. 

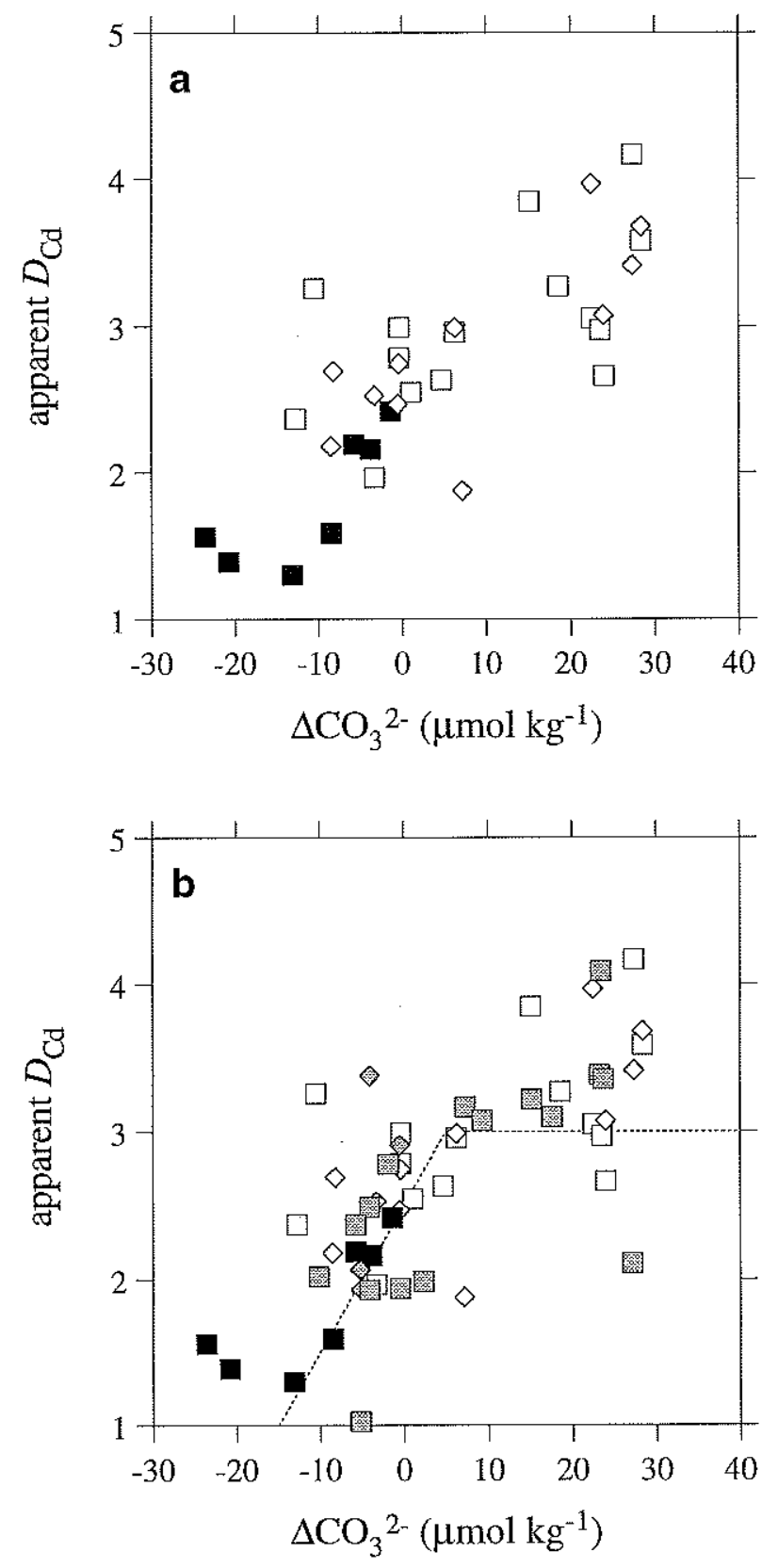

Figure 2.11. Apparent $\mathrm{Cd}$ partition coefficients in C. wuellerstorfi (squares) and Uvigerina (diamonds) from cores deeper than $3000 \mathrm{~m} v$ s. bottom water saturation state with respect to calcite $\left(\Delta \mathrm{CO}_{3}{ }^{2-}\right)$. Data in (a) are from Boyle (1988a, 1992) (open) and McCorkle et al. (1995) (filled). Panel (b) includes data from this study (shaded). Dotted lines represent a proposed two-part linear relationship (Equations 2.12, 2.13). 


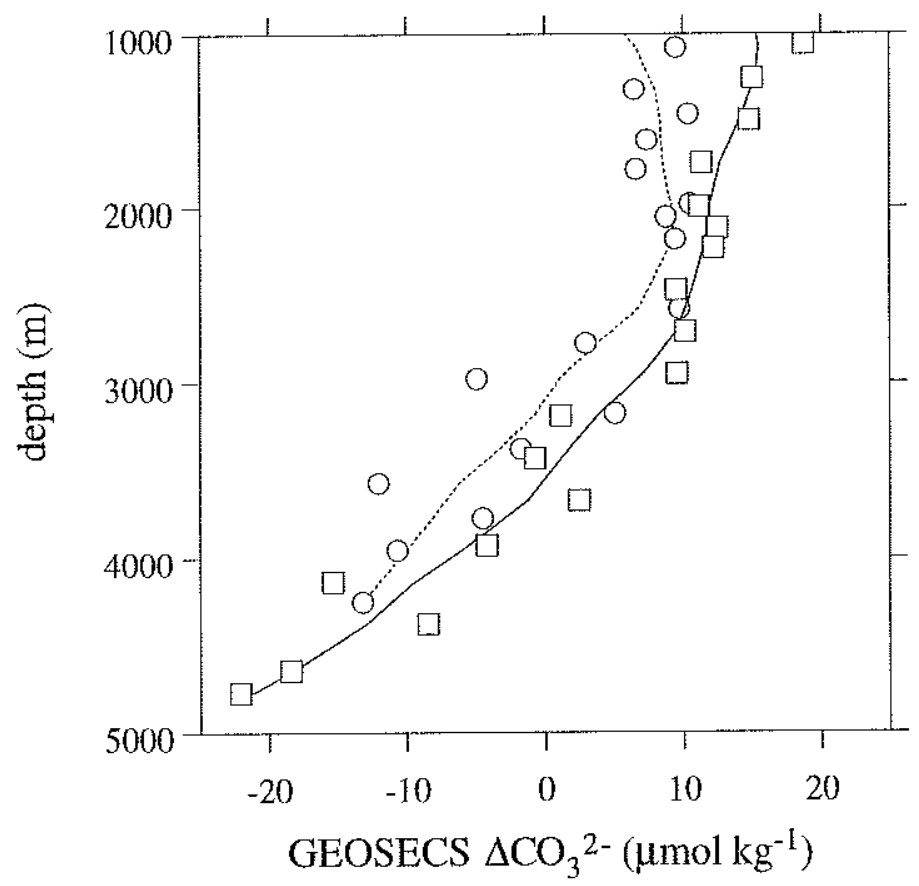

Figure 2.12. Comparison of $\Delta \mathrm{CO}_{3}{ }^{2-}$ values based on measurements made at GEOSECS Stations 334 (squares, solid curve) and 337 (circles, dotted curve) in the eastern equatorial Pacific (Broecker et al., 1982). These two stations are separated by less than 5 degrees of latitude and less than 1 degree of longitude. 


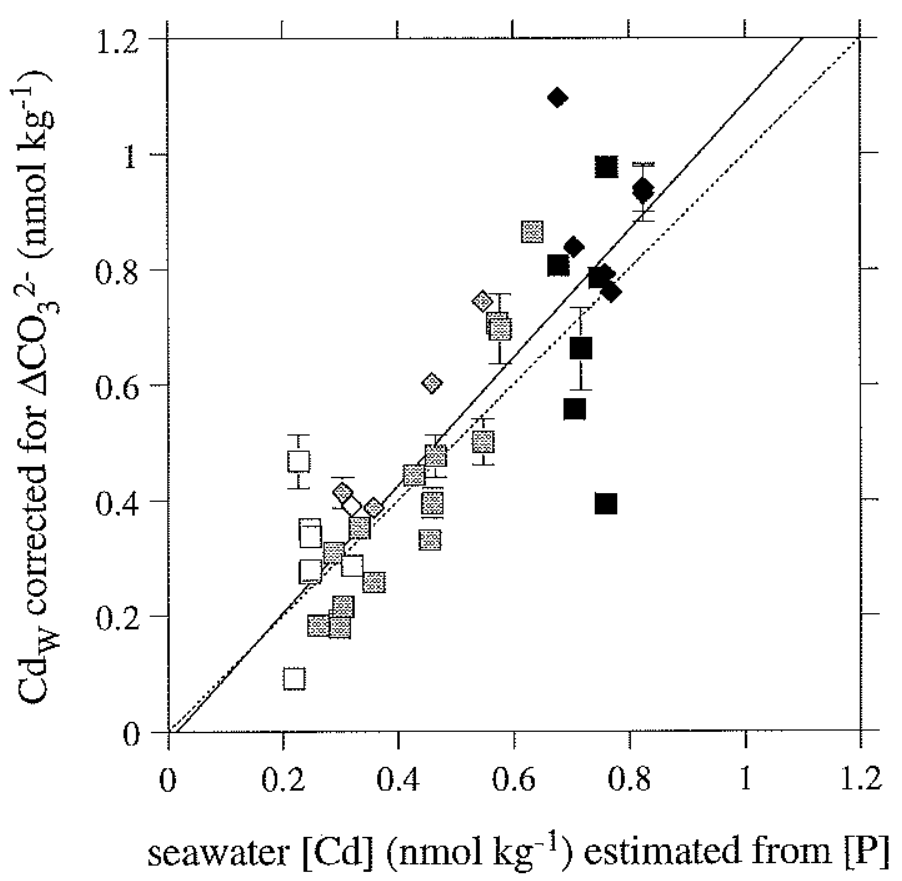

Figure 2.13. Benthic foraminiferal $\mathrm{Cd}_{\mathrm{W}}$, calculated from $\mathrm{Cd} / \mathrm{Ca}$ using partition coefficients that depend on both depth and $\mathrm{ACO}_{3}{ }^{2-}$ (Equations 2.14, 2.15), vs. bottom water dissolved $\mathrm{Cd}$ concentrations estimated from GEOSECS P. Squares are $C$. wuellerstorfi and diamonds are Uvigerina spp. Core tops are from the North Atlantic (open symbols), the tropical and South Atlantic (shaded), and the Indian and Pacific (filled). Dotted line is the 1:1 line, and solid line is the best fit $\left(r^{2}=0.73\right)$. 

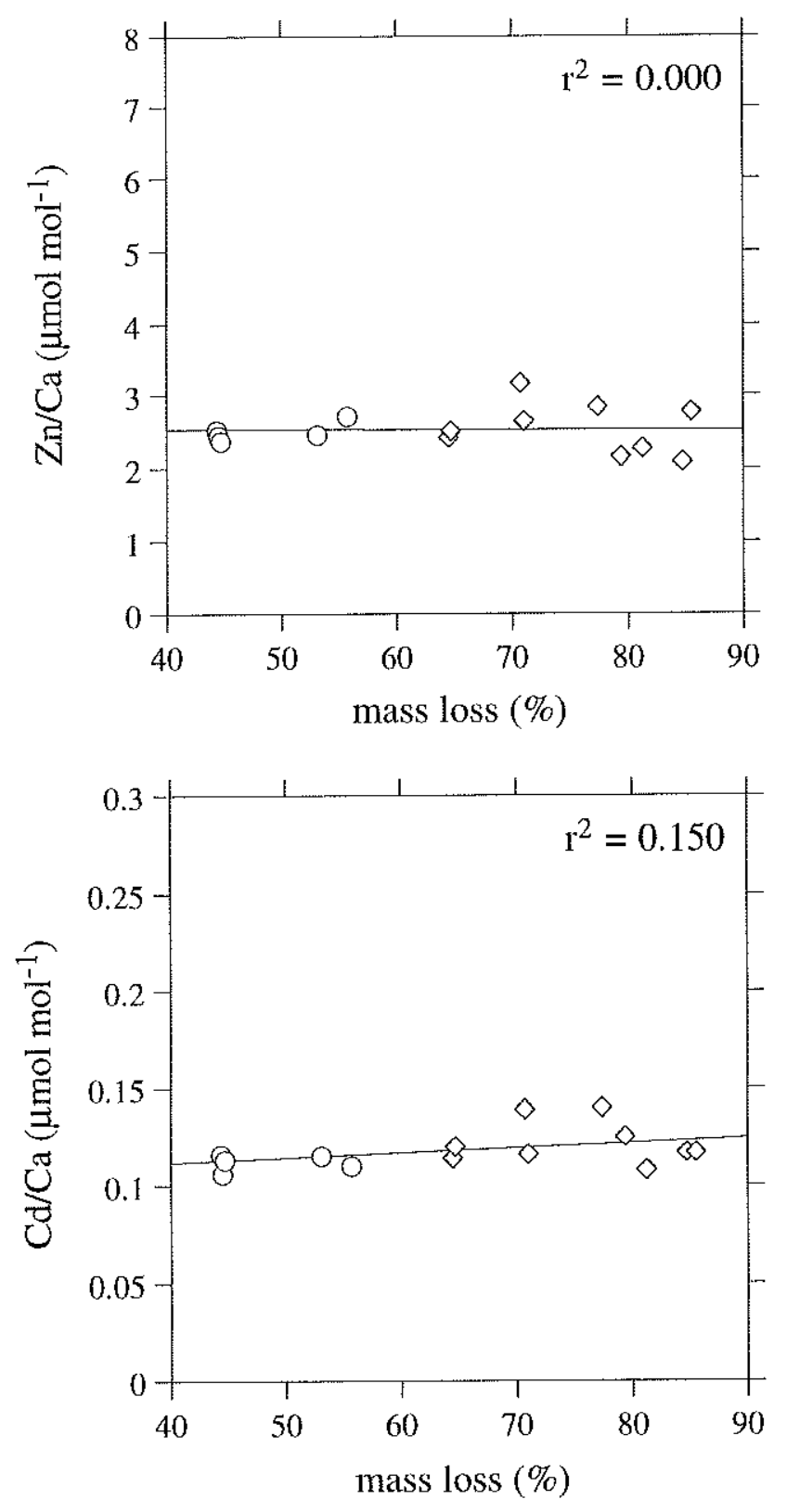

Figure 2.14. Results of a progressive dissolution experiment using Uvigerina spp. from core AII107-67GGC (33-35 cm). Five groups of 45 individuals each were crushed and split into thirds, yielding a total of 15 samples. Each sample was weighed, then subjected to the usual chemical cleaning process, which concludes with a $0.001 \mathrm{~N}$ nitric acid leach (circles). Two-thirds of the samples were then subjected to additional leaches in $0.075 \mathrm{~N}$ nitric acid (diamonds). Mass loss was calculated by comparing $\mathrm{Ca}$ concentrations to original masses. Some of the original mass includes fine sediment inside the foraminifera, so mass loss is an overestimate of foraminiferal dissolution. Note that the ordinates are scaled to encompass the full range of modern variability, and the scatter in the data is typical of foraminiferal measurements. 


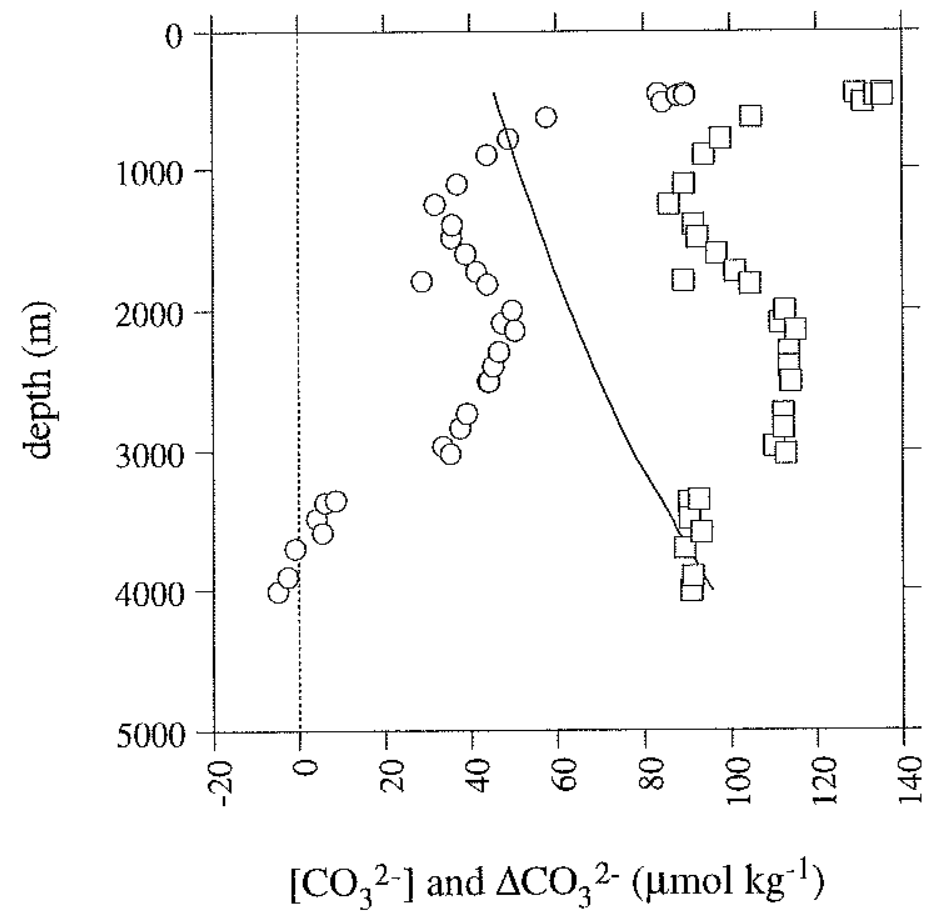

Figure 2.15. Carbonate system data calculated from alkalinity and $\Sigma \mathrm{CO}_{2}$ measurements made on water collected at each of 34 multicore stations in the vicinity of the Brazil Basin. $\Delta \mathrm{CO}_{3}{ }^{2-}$ (circles) is calculated as the difference between $\left[\mathrm{CO}_{3}{ }^{2-}\right]_{\text {in situ }}$ (squares) and $\left[\mathrm{CO}_{3}{ }^{2-}\right]_{\text {saturation }}$ (solid curve). 

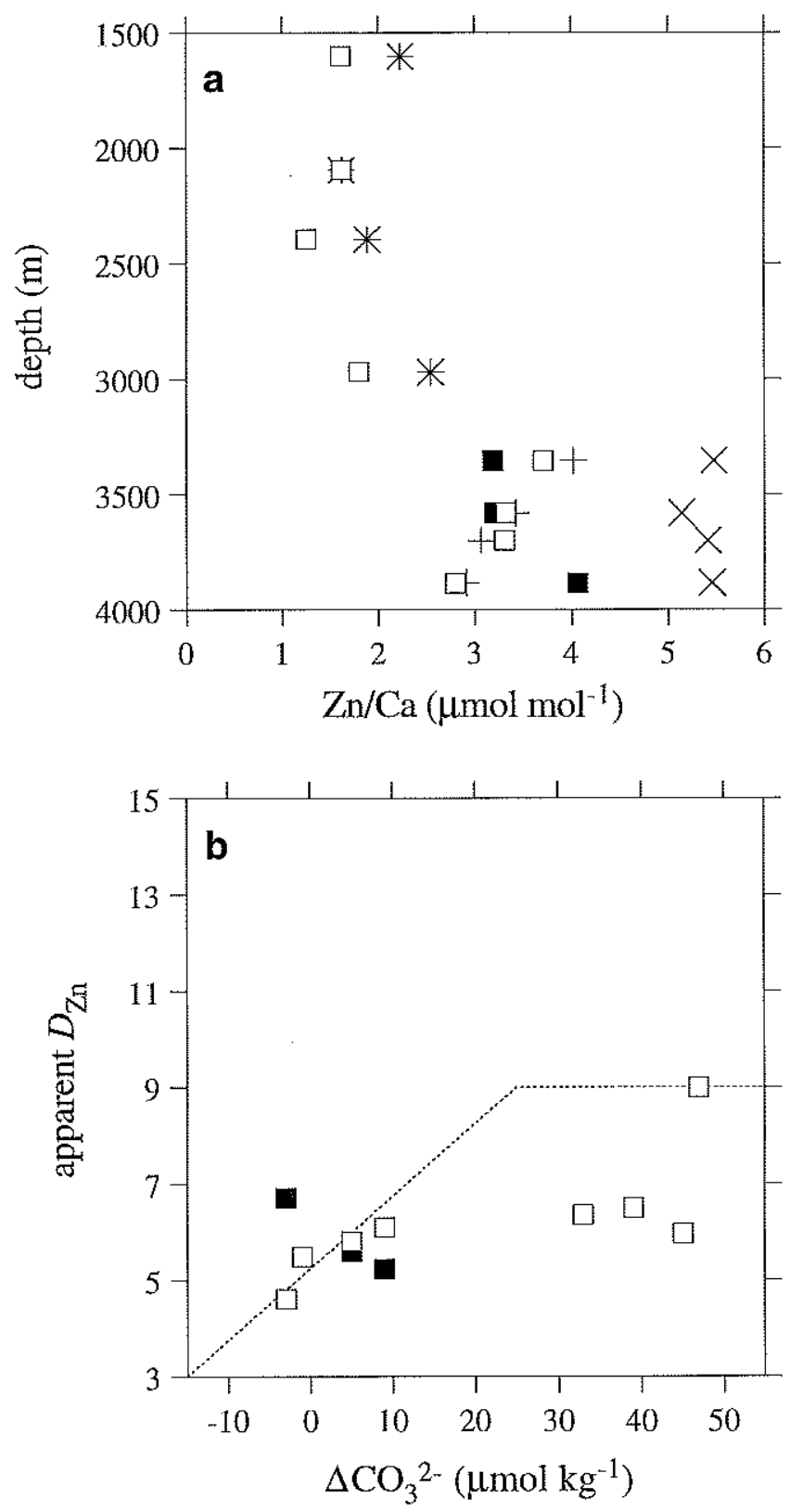

Figure 2.16. C. wuellerstorfi $\mathrm{Zn} / \mathrm{Ca}$ data from Brazil Basin multicore tops. (a) $\mathrm{Zn} / \mathrm{Ca}$ in unstained (open squares) and stained (filled squares) foraminifera, compared to predicted values based on in situ seawater Si measurements. Exes assume a constant $D_{\mathrm{Zn}}$ of 9 , while crosses use $D_{\mathrm{Zn}}$ that varies with $\Delta \mathrm{CO}_{3}{ }^{2-}$ (Equations $2.6,2.7$ ). (b) Apparent $C$. wuellerstorfi $\mathrm{Zn}$ partition coefficients $v s . \Delta \mathrm{CO}_{3}{ }^{2-}$. Dotted line represents the predicted relationship (Equations 2.6, 2.7). Note that the $D_{\mathrm{Zn}}$ error in low-Zn (high- $\Delta \mathrm{CO}_{3}{ }^{2-}$ ) waters is large, and values lower than predicted may be due to a slight overestimation of seawater $\mathrm{Zn}$ concentrations. 

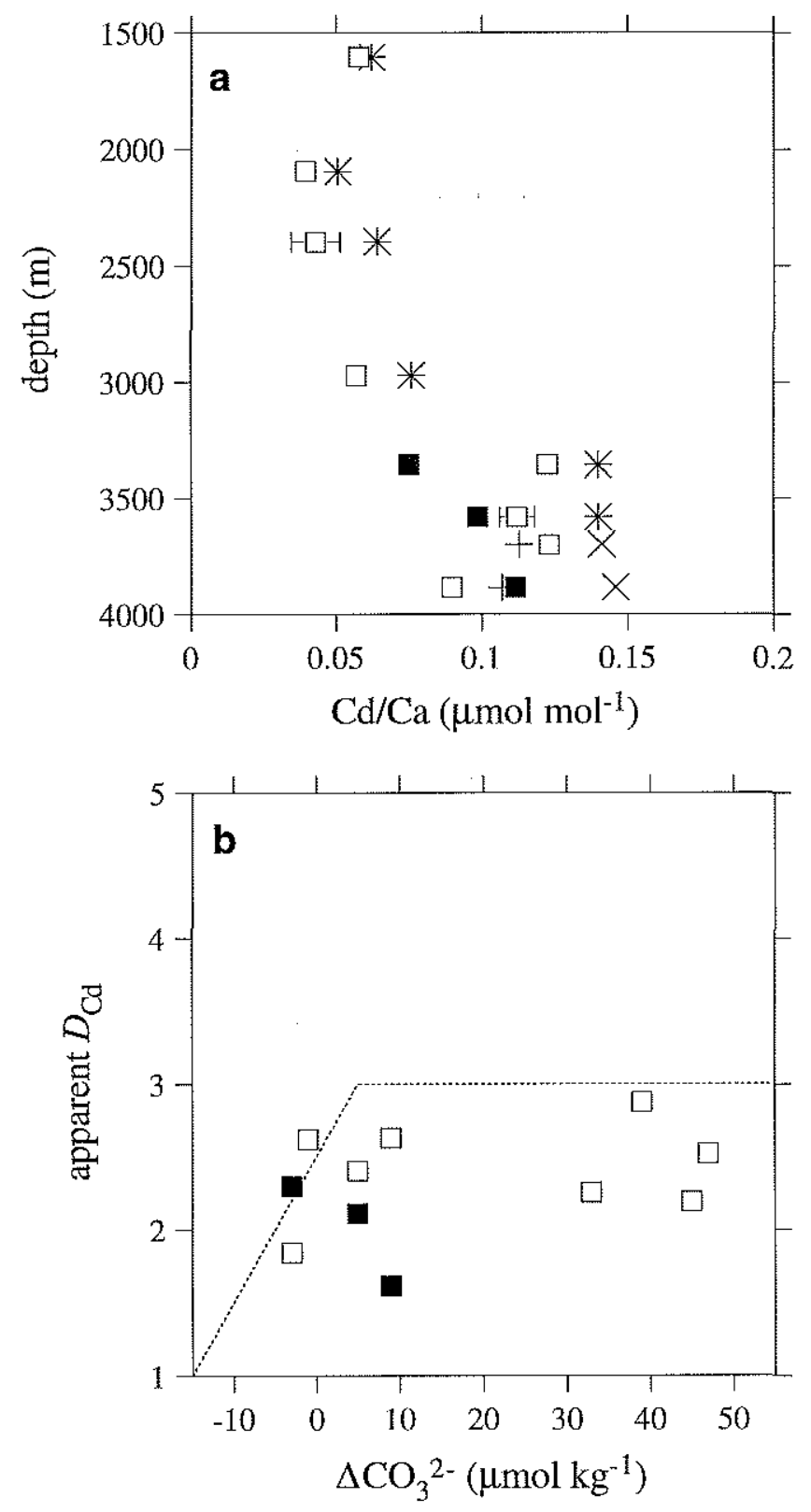

Figure 2.17. C. wuellerstorfi $\mathrm{Cd} / \mathrm{Ca}$ data from Brazil Basin multicore tops. (a) $\mathrm{Cd} / \mathrm{Ca}$ in unstained (open squares) and stained (filled squares) foraminifera, compared to predicted values based on in situ seawater P measurements. Exes assume $D_{\mathrm{Cd}}$ is a function of water depth only (Equations $2.16,2.17$ ), while crosses use $D_{\mathrm{Cd}}$ that varies with both depth and $\Delta \mathrm{CO}_{3}{ }^{2-}$ (Equations $2.14,2.15$ ). (b) Apparent $C$. wuellerstorfi $\mathrm{Cd}$ partition coefficients $v s . \Delta \mathrm{CO}_{3}^{2-} . D_{\mathrm{Cd}}$ data from shallower than $3000 \mathrm{~m}$ are depth-corrected by adding the quantity $\left(D_{\mathrm{Cd}(\mathrm{z})^{-3}}\right)$. Dotted line represents the predicted relationship (Equations $2.12,2.13$ ). Note that the $D_{\mathrm{Cd}}$ error in low-Cd (high- $\Delta \mathrm{CO}_{3}{ }^{2-}$ ) waters is large, and values lower than predicted may be due to a slight overestimation of seawater Cd concentrations. 


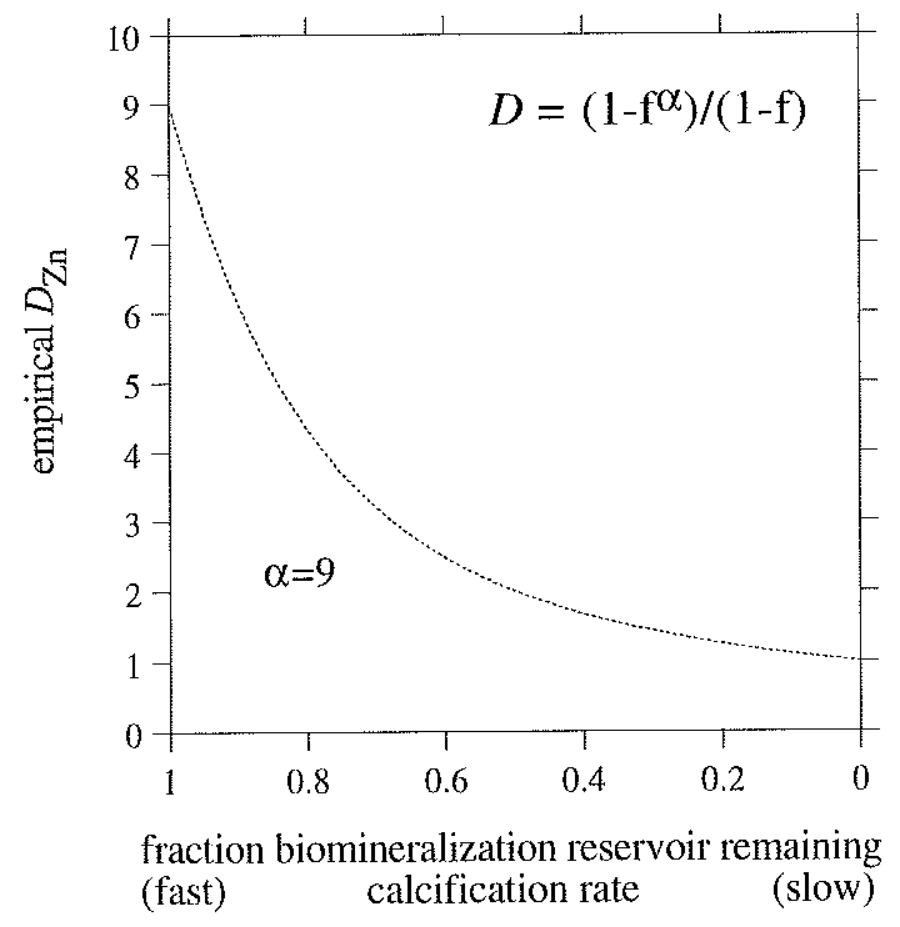

Figure 2.18. Elderfield et al.'s (1996) Rayleigh distillation model of trace metal partition coefficients. If an infinitely small fraction of the foraminiferan's internal biomineralization reservoir is consumed before flushing, $D$ will be equal to the fractionation factor $\alpha$. As more of the reservoir is consumed, $D$ approaches 1. Frequent flushing may be related to rapid calcification in supersaturated waters. 


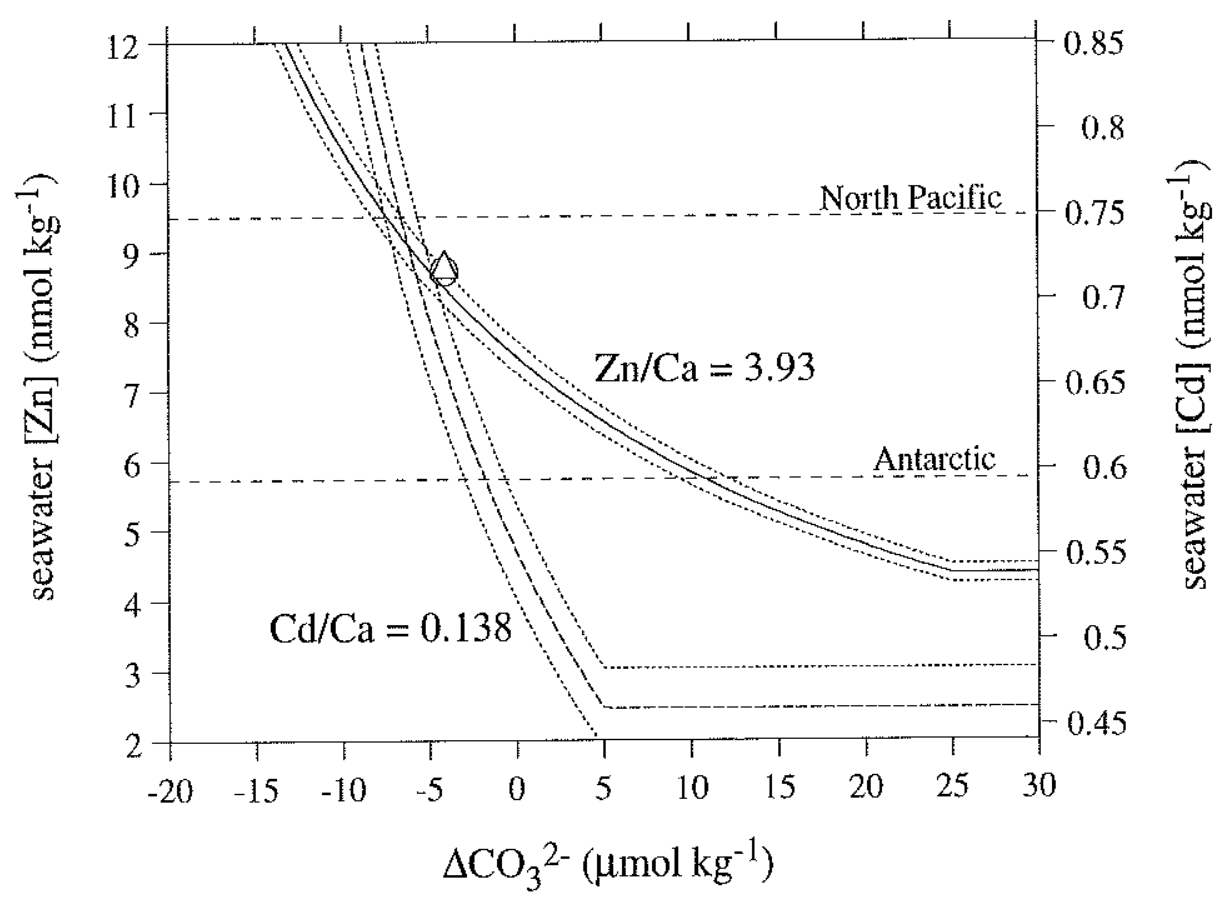

Figure 2.19. Plot showing the combinations of seawater dissolved $\mathrm{Zn}, \mathrm{Cd}$, and $\Delta \mathrm{CO}_{3}{ }^{2-}$ that could result in the $\mathrm{Zn} / \mathrm{Ca}$ (solid curve) and $\mathrm{Cd} / \mathrm{Ca}$ (dashed curve) values of C. wuellerstorfi from the top of core KNR73-4PC ( $3681 \mathrm{~m}$, eastern tropical Pacific). The ordinates are scaled to each other using tielines (horizontal dashed lines) that represent Antarctic deep water (GEOSECS Station 296) and northeast Pacific deep water (GEOSECS Station 347) estimated dissolved $\mathrm{Zn}$ and $\mathrm{Cd}$ concentrations along the isopycnal corresponding to the water above KNR73-4PC. This scaling thus approximates the relationship between $\mathrm{Zn}$ and $\mathrm{Cd}$ within the modern deep Pacific. The point where the $\mathrm{Zn} / \mathrm{Ca}$ and $\mathrm{Cd} / \mathrm{Ca}$ curves intersect represents a unique solution for this core site. Dotted error envelopes are the mean standard deviations of replicate measurements from the core top calibration $\left(+/-0.12 \mu \mathrm{mol} \mathrm{mol}^{-1}\right.$ for $\mathrm{Zn} / \mathrm{Ca}$ and $+/-0.007 \mu \mathrm{mol} \mathrm{mol}{ }^{-1}$ for $\mathrm{Cd} / \mathrm{Ca}$ ). Uncertainties in the equations relating partition coefficients to $\mathrm{ACO}_{3}{ }^{2-}$ may introduce additional error. Also plotted for comparison are estimated values of dissolved $\mathrm{Zn}$ (triangle), $\mathrm{Cd}$ (circle), and $\mathrm{ACO}_{3}{ }^{2-}$ from the nearest GEOSECS station (Station 340). 


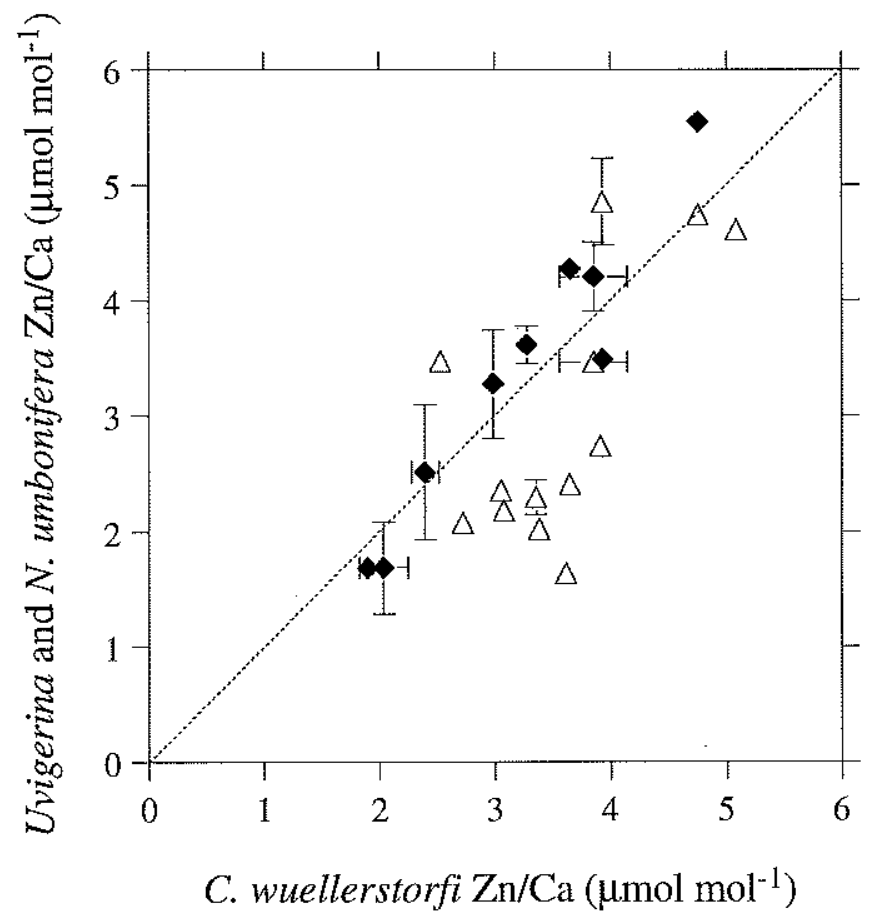

Figure 2.20. $\mathrm{Zn} / \mathrm{Ca}$ comparison of Uvigerina (diamonds) and $N$. umbonifera (triangles) to C. wuellerstorfi in cores from the core top calibration. Error bars are +/$1 \sigma$ of replicates. 


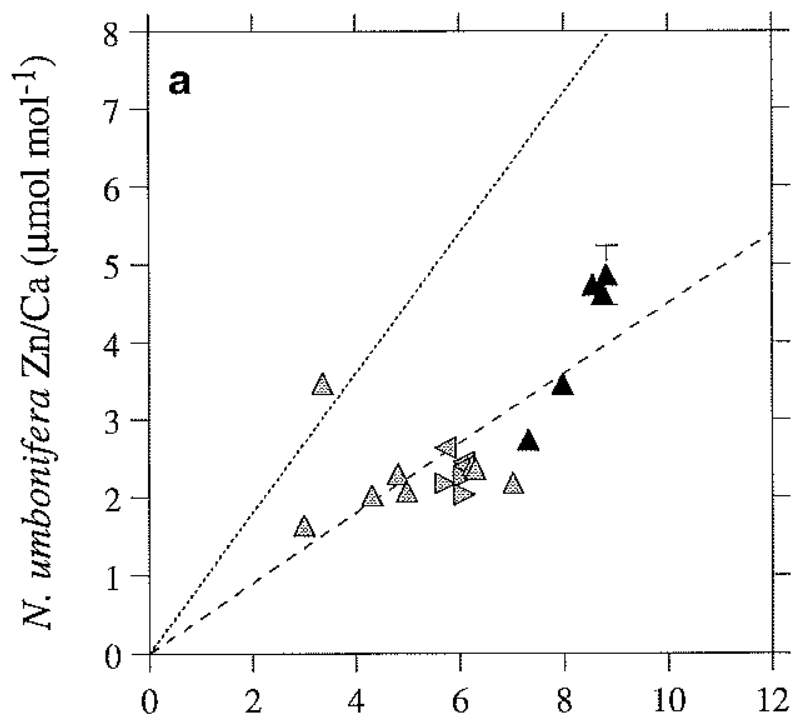

seawater [Zn] $\left(\mathrm{nmol} \mathrm{kg}^{-1}\right)$ estimated from [Si]

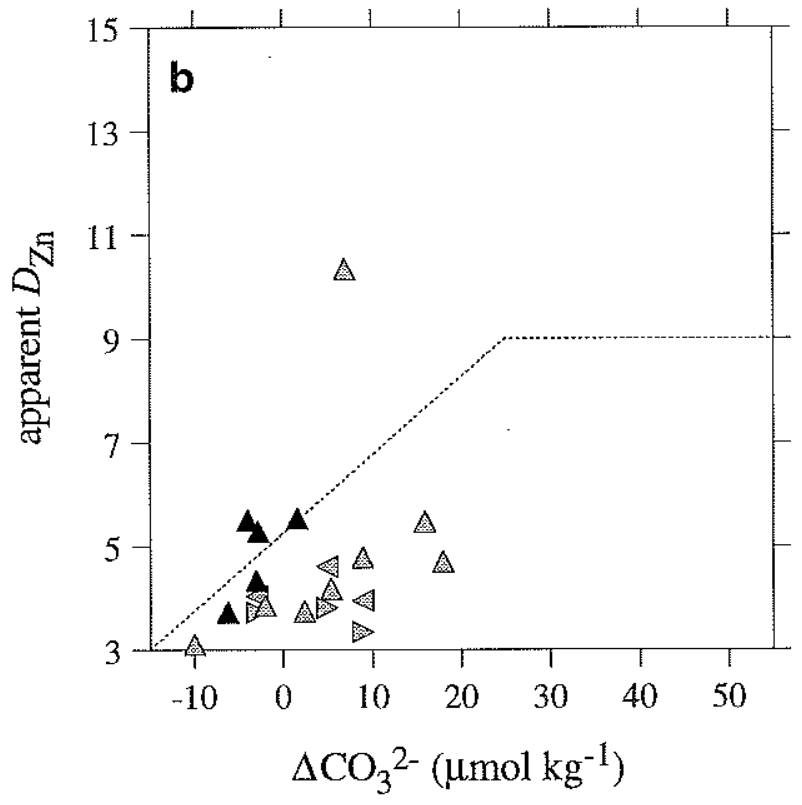

Figure 2.21. (a) $N$. umbonifera $\mathrm{Zn} / \mathrm{Ca} v$ s. seawater $\mathrm{Zn}$ concentrations in the tropical and South Atlantic (shaded), and Indian and Pacific (filled). Left-pointing triangles are unstained ("dead") individuals from Brazil Basin multicores, and right-pointing triangles are stained ("live") specimens. Dotted line represents a $D_{\mathrm{Zn}}$ of 9 , and dashed line represents a $D_{\mathrm{Zn}}$ of 4.5 (not necessarily the best fit). (b) Apparent $\mathrm{Zn}$ partition coefficients $v s . \Delta \mathrm{CO}_{3}{ }^{2-}$ for the samples in (a). Dotted lines show the relationship followed by $C$. wuellerstorfi and Uvigerina (Equations 2.6, 2.7). 


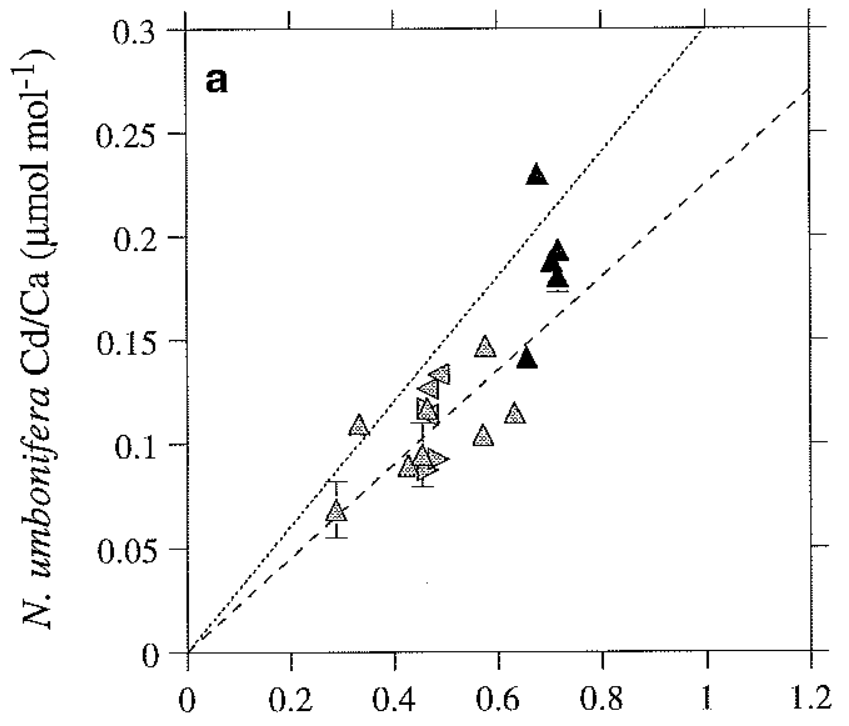

seawater $[\mathrm{Cd}]\left(\mathrm{nmol} \mathrm{kg}{ }^{-1}\right)$ estimated from $[\mathrm{P}]$

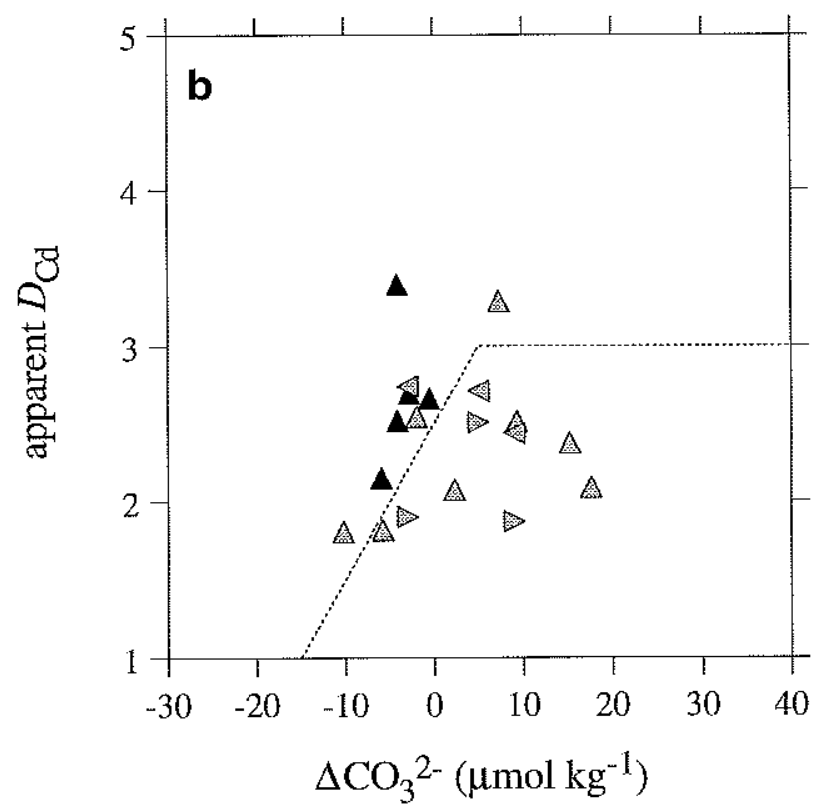

Figure 2.22. (a) $N$. umbonifera $\mathrm{Cd} / \mathrm{Ca}$ vs. seawater $\mathrm{Cd}$ concentrations in the tropical and South Atlantic (shaded), and Indian and Pacific (filled). Left-pointing triangles are unstained ("dead") individuals from Brazil Basin multicores, and right-pointing triangles are stained ("live") specimens. All cores are from deeper than $3000 \mathrm{~m}$. Dotted line represents a $D_{\mathrm{Cd}}$ of 3 , and dashed line represents a $D_{\mathrm{Cd}}$ of 2.25 (not necessarily the best fit). (b) Apparent $\mathrm{Cd}$ partition coefficients $v s . \Delta \mathrm{CO}_{3}{ }^{2-}$ for the samples in (a). Dotted lines show the relationship followed by $C$. wuellerstorfi and Uvigerina (Equations 2.12, 2.13). 


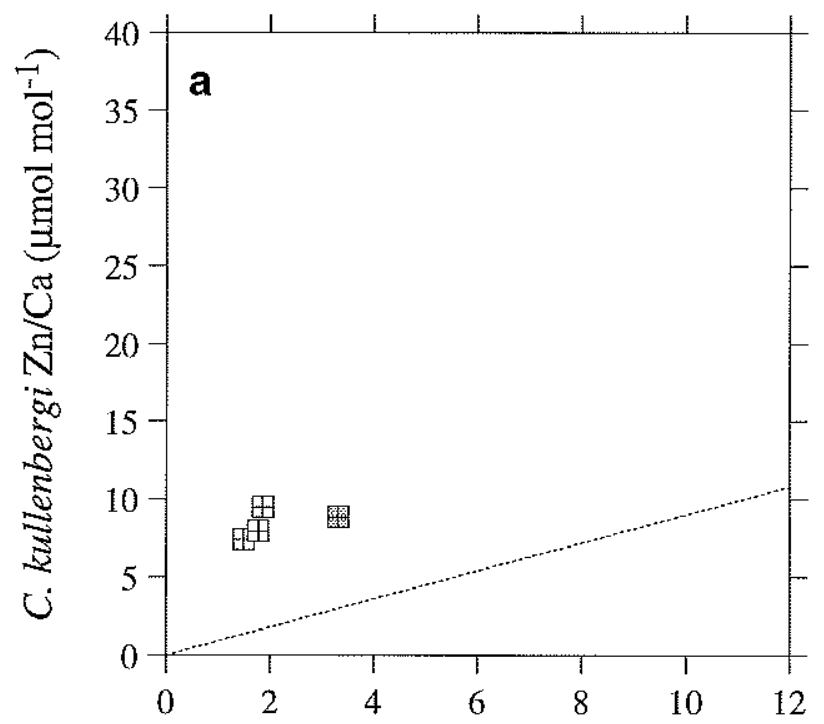

seawater [ $\mathrm{Zn}]\left(\mathrm{nmol} \mathrm{kg}^{-1}\right)$ estimated from [Si]

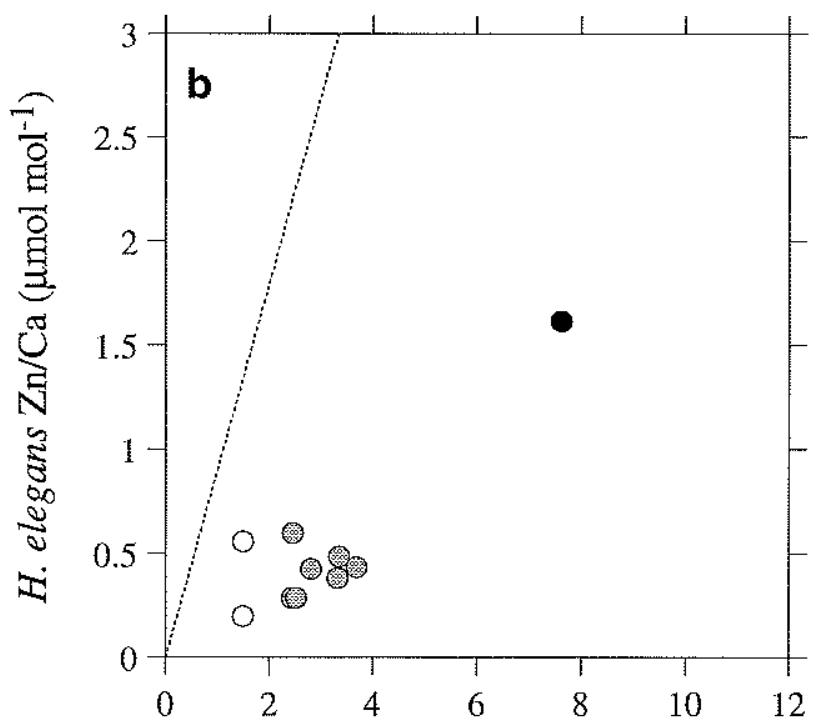

seawater [ $\mathrm{Zn}]\left(\mathrm{nmol} \mathrm{kg}^{-1}\right)$ estimated from [Si]

Figure 2.23. $\mathrm{Zn} / \mathrm{Ca}$ in C. kullenbergi (includes C. pachyderma) (a) and H. elegans (b) vs. seawater dissolved $\mathrm{Zn}$ concentrations. Data are from North Atlantic (open), tropical and South Atlantic (shaded), and Indian Ocean (filled). Dotted lines represent a $D_{\mathrm{Zn}}$ of 9 . 
Table 2.1. $\mathrm{Zn} / \mathrm{Ca}$ ratios of Holocene benthic foraminifera

\begin{tabular}{|c|c|c|c|c|c|c|c|c|}
\hline \multirow[b]{2}{*}{ Core } & \multicolumn{3}{|l|}{$\begin{array}{l}\text { Sample } \\
\text { depth }\end{array}$} & \multirow{2}{*}{$\begin{array}{l}\text { Water } \\
\text { depth } \\
\text { (m) }\end{array}$} & \multicolumn{2}{|c|}{ GEOSECS est. } & \multicolumn{2}{|c|}{$\mathrm{Zn} / \mathrm{Ca}\left(\mu \mathrm{mol} \mathrm{mol}{ }^{-1}\right)$} \\
\hline & $(\mathrm{cm})$ & Latitude & Longitude & & $(\mu \mathrm{mc}$ & & C. wueller. & Uvigerina \\
\hline AII15-765a & 3 & $32^{\circ} 01 \mathrm{~S}$ & $49^{\circ} 56^{\prime} \mathrm{E}$ & 3698 & 126 & -6 & $3.91 \pm 0.05$ & \\
\hline AII $54-9-5^{a}$ & $0-2$ & $9^{\circ} 31 \mathrm{~s}$ & $94^{\circ} 13^{\prime} \mathrm{W}$ & 3960 & 138 & -4 & $3.85 \pm 0.29$ & $4.20 \pm 0.30$ \\
\hline AII $107-65 \mathrm{GGC}^{\mathrm{b}}$ & $1-3$ & $32^{\circ} 02^{\prime} \mathrm{S}$ & $36^{\circ} 11 \mathrm{~W}$ & 2795 & 33 & 45 & $2.31 \pm 0.12$ & \\
\hline AII $107-67 \mathrm{GGC}^{\mathrm{b}}$ & $3-9$ & $31^{\circ} 55^{\prime} \mathrm{S}$ & $36^{\circ} 12^{\prime} \mathrm{W}$ & 2587 & 32 & 47 & $2.40 \pm 0.12$ & $2.51 \pm 0.58$ \\
\hline AII $07-69$ GGC $^{\mathrm{b}}$ & 4 & $31^{\circ} 40^{\prime} \mathrm{S}$ & $36^{\circ} 01^{\prime} \mathrm{W}$ & 2158 & 39 & 47 & $1.90 \pm 0.03$ & $1.68 \pm 0.01$ \\
\hline All $107-71 G^{G G C}$ & $5-7$ & $31^{\circ} 31^{\prime} \mathrm{S}$ & $35^{\circ} 56^{\prime} \mathrm{W}$ & 1887 & 49 & 43 & $2.99 \pm 0.09$ & $3.27 \pm 0.47$ \\
\hline AII107-73GGC ${ }^{b}$ & $3-5$ & $31^{\circ} 25 \mathrm{~S}$ & $35^{\circ} 53^{\prime} \mathrm{W}$ & 1660 & 56 & 38 & $3.28 \pm 0.03$ & $3.61 \pm 0.16$ \\
\hline AII107-124GGC & $3-5$ & $30^{\circ} 55^{\prime} \mathrm{S}$ & $38^{\circ} 39^{\prime} \mathrm{W}$ & 3800 & 77 & 9 & $3.36 \pm 0.06$ & \\
\hline AIIlo7-131GGC ${ }^{b}$ & 4 & $30^{\circ} 53 ' \mathrm{~S}$ & $38^{\circ} 03^{\prime} \mathrm{W}$ & 2925 & 34 & 43 & $2.37 \pm 0.24$ & \\
\hline AII107-142GGC & $3-6$ & $30^{\circ} 57 \mathrm{~S}$ & $39^{\circ} 00^{\prime} \mathrm{W}$ & 4148 & 120 & -10 & 3.08 & \\
\hline All107-144GGC & $0-1$ & $31^{\circ} 01^{\prime} S$ & $38^{\circ} 52^{\prime} \mathrm{W}$ & 3988 & 105 & -2 & $3.65 \pm 0.04$ & \\
\hline AII107-147GGC & $3-5$ & $30^{\circ} 49^{\prime} \mathrm{S}$ & $38^{\circ} 31^{\prime} \mathrm{W}$ & 3658 & 68 & 18 & $3.39 \pm 0.08$ & \\
\hline CHN82-4PG & $0-3$ & $41^{\circ} 43^{\prime} \mathrm{N}$ & $32^{\circ} 51^{\prime} \mathrm{W}$ & 3427 & 21 & 23 & $1.65 \pm 0.01$ & \\
\hline CHN82-11PG ${ }^{\mathrm{c}, \mathrm{e}}$ & $6-8$ & $42^{\circ} 23^{\prime} \mathrm{N}$ & $31^{\circ} 48^{7} \mathrm{~W}$ & 3209 & 19 & 23 & 1.70 & \\
\hline CHN82-15PC & $0-6$ & $43^{\circ} 22^{\prime} \mathrm{N}$ & $28^{\circ} 14^{\prime} \mathrm{W}$ & 2151 & 14 & 30 & $2.11 \pm 0.21$ & \\
\hline CHN82-20PG ${ }^{\mathrm{d}}$ & $3-9$ & $43^{\circ} 30^{\prime} \mathrm{N}$ & $29^{\circ} 52^{\prime} \mathrm{W}$ & 3020 & 18 & 24 & $1.60 \pm 0.06$ & \\
\hline DSDP $-552 A-1-19$ & $7-9$ & $56^{\circ} 03^{\prime} \mathrm{N}$ & $23^{\circ} 14^{\prime} \mathrm{W}$ & 2311 & 14 & 29 & $2.78 \pm 0.22$ & \\
\hline EN66-36GGC & $3-4$ & $4^{\circ} 18 \mathrm{~N}$ & $20^{\circ} 13^{\prime} \mathrm{W}$ & 4270 & 49 & 7 & 2.53 & \\
\hline KNR73-3PC & $13-15$ & $0^{\circ} 22 \mathrm{~N}$ & $106^{\circ} 11 \mathrm{~W}$ & 3606 & 150 & -1 & $4.76 \pm 0.05$ & 5.55 \\
\hline KNR73-4PC ${ }^{\mathrm{i}}$ & $5-7$ & $10^{\circ} 51^{\prime} \mathrm{N}$ & $110^{\circ} 16^{\prime} \mathrm{W}$ & 3681 & 154 & -4 & $3.93 \pm 0.03$ & 3.49 \\
\hline KNR110-50GGCj & $0-2$ & $4^{\circ} 52^{\prime} \mathrm{N}$ & $43^{\circ} 12^{\prime} \mathrm{W}$ & 3995 & 42 & 15 & 3.62 & \\
\hline KNR110-55GGCj & $0-2$ & $4^{\circ} 57^{\prime} \mathrm{N}$ & $42^{\circ} 53^{\prime} \mathrm{W}$ & 4556 & 106 & -6 & $3.06 \pm 0.11$ & \\
\hline KNR110-58GGCj & 7 & $4^{\circ} 48^{\prime} \mathrm{N}$ & $43^{\circ} 20^{\prime} \mathrm{W}$ & 4341 & 81 & 2 & $2.72 \pm 0.05$ & \\
\hline KNR110-66GGCj & 7 & $4^{\circ} 34 \mathrm{~N}$ & $43^{\circ} 23^{\prime} \mathrm{W}$ & 3547 & 32 & 27 & $2.24 \pm 0.04$ & \\
\hline ODP-658A-1H-1k & $18-20$ & $20^{\circ} 45^{\prime} \mathrm{N}$ & $18^{\circ} 35^{\prime} \mathrm{W}$ & 2263 & 30 & 46 & $2.04 \pm 0.21$ & $1.69 \pm 0.40$ \\
\hline ODP-714A-1H-1 & $3-5$ & $5^{\circ} 04^{\prime} \mathrm{N}$ & $73^{\circ} 47^{\circ} \mathrm{E}$ & 2195 & 132 & 17 & 5.38 & \\
\hline ODP-806B-1H-1 & $3-5$ & $0^{\circ} 19^{\prime} \mathrm{N}$ & $159^{\circ} 22^{\prime} \mathrm{E}$ & 2520 & 149 & 8 & 5.84 & \\
\hline ODP-851B-1H-1n & $8-10$ & $2^{\circ} 46^{\prime} \mathrm{N}$ & $110^{\circ} 34^{\prime} \mathrm{W}$ & 3761 & 153 & -3 & 5.09 & \\
\hline ODP-883D-1H-10 & $3-5$ & $51^{\circ} 12 \mathrm{~N}$ & $167^{\circ} 46^{\prime} \mathrm{E}$ & 2384 & 175 & -5 & & $4.11 \pm 0.33$ \\
\hline RNDB-GGClp & $9-11$ & $51^{\circ} 09 \mathrm{~N}$ & $167^{\circ} 39^{\prime} \mathrm{E}$ & 2393 & 175 & -5 & & $3.85 \pm 0.23$ \\
\hline $\mathrm{V} 29-204 \mathrm{C}$ & $15-20$ & $61^{\circ} 11^{\prime} \mathrm{N}$ & $23^{\circ} 01^{\prime} \mathrm{W}$ & 1849 & 11 & 39 & 1.22 & \\
\hline VINO-BC26P & $3-11$ & $52^{\circ} 59^{\prime} \mathrm{N}$ & $164^{\circ} 39^{\prime} \mathrm{E}$ & 2960 & 171 & -5 & & 3.85 \\
\hline VINO-GGC37p & $3-7$ & $50^{\circ} 25^{\prime} \mathrm{N}$ & $167^{\circ} 44^{\prime} \mathrm{E}$ & 3300 & 168 & -5 & 3.65 & 4.27 \\
\hline
\end{tabular}

Superscripts on core names indicate sources of data verifying that each core top is Holocene in age: (a) Graham et al., 1981; (b) Jones et al., 1984; (c) this study; (d) Boyle and Keigwin, 1985/86; (e) Boyle and Keigwin, 1982; (f) Boyle and Keigwin, 1987; (g) Shackleton and Hall, 1984; (h) Curry and Lohmann, 1983; (i) Boyle, 1992; (j) Curry and Lohmann, 1990; (k) Sarnthein and Tiedemann, 1989; (l) Droxler et al., 1990; (m) Berger et al., 1993; (n) Ravelo and Shackleton, 1995; (o) Keigwin, 1995; (p) Keigwin, 1998; (q) Curry et al., in press. $\Delta \mathrm{CO}_{3}{ }^{2-}$ was recalculated from GEOSECS measurements of alkalinity, $\Sigma \mathrm{CO}_{2}$, temperature, and salinity (see Appendix 2). Reported $\mathrm{Zn} / \mathrm{Ca}$ errors are $\pm 1 \sigma$ on means of two to three measurements. From a total of $87 \mathrm{Zn} / \mathrm{Ca}$ measurements, three were judged to be significantly contaminated (values much higher than replicates) and were not included in the means. All data are listed in Table 2.2. 
Table 2.2. All data from the core top calibration, grouped by species

\begin{tabular}{|c|c|c|c|c|c|c|c|c|}
\hline core, sample depth & {$[\mathrm{Ca}]$} & $\mathrm{Zn} / \mathrm{Ca}$ & mean & std dev & $\mathrm{Cd} / \mathrm{Ca}$ & mean & std dev & $\mathrm{Mn} / \mathrm{Ca}$ \\
\hline \multicolumn{9}{|l|}{ C. wuellerstorfi } \\
\hline \multirow[t]{2}{*}{ AII $15-765,3 \mathrm{~cm}$} & 8.30 & 3.88 & 3.91 & 0.05 & 0.325 & & & 12.7 \\
\hline & $\mathrm{I} 1.90$ & 3.95 & & & 0.254 & & & 14.3 \\
\hline \multirow[t]{2}{*}{ AII54-9-5, 0-2 cm } & 10.99 & 3.65 & 3.85 & 0.29 & $\overline{0.168}$ & 0.169 & 0.000 & 110.9 \\
\hline & 6.60 & 4.06 & & & 0.169 & & & 127.7 \\
\hline \multirow[t]{3}{*}{ AlI107-65GGC, $1-3 \mathrm{~cm}$} & 16.05 & $\underline{4.51}$ & 2.31 & 0.12 & 0.052 & 0.053 & 0.001 & 7.8 \\
\hline & 15.21 & 2.39 & & & 0.053 & & & 7.4 \\
\hline & 12.53 & 2.22 & & & 0.055 & & & 6.5 \\
\hline \multirow[t]{3}{*}{ AII107-67GGC, 3-9 cm } & 12.55 & 2.42 & 2.40 & 0.12 & 0.054 & 0.057 & 0.005 & 7.0 \\
\hline & 18.91 & 2.27 & & & 0.062 & & & 9.6 \\
\hline & 21.99 & 2.50 & & & 0.054 & & & 10.4 \\
\hline \multirow[t]{3}{*}{ AII $107.69 \mathrm{GGC}, 4 \mathrm{~cm}$} & 11.22 & $\underline{3.02}$ & 1.90 & 0.03 & 0.059 & 0.057 & 0.004 & 6.0 \\
\hline & 19.67 & 1.88 & & & 0.061 & & & 10.8 \\
\hline & 22.78 & 1.92 & & & 0.053 & & & 10.0 \\
\hline \multirow[t]{3}{*}{ All107-71GGC, $5-7 \mathrm{~cm}$} & 25.20 & 2.95 & 2.99 & 0.09 & 0.076 & 0.078 & 0.005 & 20.8 \\
\hline & 15.98 & 2.92 & & & 0.084 & & & 20.5 \\
\hline & 18.12 & 3.09 & & & 0.075 & & & 15.0 \\
\hline \multirow[t]{3}{*}{ AII107-73GGC, $3.5 \mathrm{~cm}$} & 21.63 & 3.29 & 3.28 & 0.03 & 0.088 & 0.089 & 0.007 & 18.7 \\
\hline & 24.46 & 3.24 & & & 0.096 & & & 21.1 \\
\hline & 14.66 & 3.30 & & & 0.082 & & & 18.9 \\
\hline \multirow[t]{3}{*}{ All $107-124 \mathrm{GGC}, 3-5 \mathrm{~cm}$} & 24.14 & 3.41 & 3.36 & 0.06 & 0.146 & 0.143 & 0.011 & 15.9 \\
\hline & 15.21 & 3.37 & & & 0.152 & & & 14.0 \\
\hline & 16.57 & 3.29 & & & 0.131 & & & 16.5 \\
\hline \multirow[t]{2}{*}{ All107-131GGC, $4 \mathrm{~cm}$} & 18.22 & 2.20 & 2.37 & 0.24 & 0.048 & 0.053 & 0.007 & 0.2 \\
\hline & 13.10 & 2.54 & & & 0.057 & & & 6.1 \\
\hline AII 107-142GGC, $3-6 \mathrm{~cm}$ & 5.45 & 3.08 & 3.08 & & 0.128 & 0.128 & & 0.0 \\
\hline \multirow[t]{3}{*}{ AIII07-144GGC, 0-1 cm } & 22.39 & 3.69 & 3.65 & 0.04 & 0.173 & 0.161 & 0.014 & 8.1 \\
\hline & 18.39 & 3.64 & & & 0.165 & & & 11.3 \\
\hline & 17.79 & 3.62 & & & 0.145 & & & 10.3 \\
\hline \multirow[t]{3}{*}{ All107-147GGC, $3-5 \mathrm{~cm}$} & 20.84 & 3.30 & 3.39 & 0.08 & 0.130 & 0.133 & 0.004 & 14.1 \\
\hline & 17.60 & 3.40 & & & 0.137 & & & $\mathrm{wr}$ \\
\hline & 13.06 & 3.46 & & & 0.132 & & & n: \\
\hline \multirow[t]{2}{*}{ CHN82-4PG, 0-3 cm } & 15.20 & 1.64 & 1.64 & 0.01 & 0.097 & 0.101 & 0.007 & 23.4 \\
\hline & 17.90 & 1.65 & & & 0.106 & & & 27.7 \\
\hline CHN82-11PG, $6-8 \mathrm{~cm}$ & 14.51 & 1.70 & 1.70 & & 0.084 & 0.084 & & 13.7 \\
\hline \multirow[t]{3}{*}{ CHN82-15PC, $0-6 \mathrm{~cm}$} & 15.05 & 1.96 & 2.11 & 0.21 & 0.075 & 0.078 & 0.003 & 13.7 \\
\hline & 7.88 & 2.26 & & & 0.080 & & & 9.3 \\
\hline & 12.94 & $\underline{3.48}$ & & & $\underline{0.127}$ & & & 16.1 \\
\hline \multirow[t]{2}{*}{ CHN82-20PG, 3-9 cm } & 11.21 & $\overline{1.64}$ & 1.59 & 0.06 & $\overline{0.082}$ & 0.083 & 0.001 & 18.5 \\
\hline & 11.43 & 1.55 & & & 0.083 & & & 17.6 \\
\hline \multirow[t]{3}{*}{ DSDP-552A, $7-9 \mathrm{~cm}$} & 12.17 & 2.98 & 2.78 & 0.22 & 0.099 & 0.111 & 0.011 & 15.8 \\
\hline & 11.79 & 2.54 & & & 0.119 & & & 12.5 \\
\hline & 14.42 & 2.83 & & & 0.114 & & & 16.2 \\
\hline EN66-36GGC, $3-4 \mathrm{~cm}$ & 8.67 & 2.53 & 2.53 & & 0.106 & 0.106 & & 5.1 \\
\hline \multirow[t]{2}{*}{ KNR73-3PC, $13-15 \mathrm{~cm}$} & 12.64 & 4.72 & 4.76 & 0.05 & 0.135 & 0.136 & 0.002 & 12.6 \\
\hline & 12.63 & 4.79 & & & 0.138 & & & 11.9 \\
\hline \multirow[t]{2}{*}{ KNR73-4PC, $5-7 \mathrm{~cm}$} & 7.07 & 3.91 & 3.93 & 0.03 & 0.149 & 0.138 & 0.015 & 12.0 \\
\hline & 14.19 & 3.95 & & & 0.128 & & & 20.8 \\
\hline KNR110-50GGC, $0-2 \mathrm{~cm}$ & 8.57 & 3.62 & 3.62 & & 0.093 & 0.093 & & 4.8 \\
\hline KNR110-55GGC, $0-2 \mathrm{~cm}$ & 8.92 & 2.94 & 3.06 & 0.11 & 0.138 & 0.136 & 0.002 & 0.0 \\
\hline & 15.99 & 3.17 & & & 0.135 & & & 5.0 \\
\hline & 18.79 & 3.07 & & & 0.134 & & & 5.9 \\
\hline
\end{tabular}




\begin{tabular}{|c|c|c|c|c|c|c|c|c|}
\hline core, sample depth & [Ca] & $\mathrm{Zn} / \mathrm{Ca}$ & mean & std dev & $\mathrm{Cd} / \mathrm{Ca}$ & mean & std dev & $\mathrm{Mn} / \mathrm{Ca}$ \\
\hline \multirow[t]{3}{*}{$\mathrm{KNR} 110-58 \mathrm{GGC}, 7 \mathrm{~cm}$} & 19.27 & 2.67 & 2.72 & 0.05 & 0.084 & 0.090 & 0.006 & 8.1 \\
\hline & 18.45 & 2.78 & & & 0.093 & & & 10.0 \\
\hline & 23.67 & 2.72 & & & 0.095 & & & 7.7 \\
\hline \multirow[t]{2}{*}{ KNR110 66GGC, $7 \mathrm{~cm}$} & 15.85 & 2.21 & 2.24 & 0.04 & 0.054 & 0.055 & 0.001 & 2.7 \\
\hline & 16.65 & 2.27 & & & 0.056 & & & 3.3 \\
\hline \multirow[t]{2}{*}{ ODP $-658 \mathrm{~A}, 18-20 \mathrm{~cm}$} & 17.28 & 2.19 & 2.04 & 0.21 & 0.065 & 0.066 & 0.001 & 20.1 \\
\hline & 20.06 & 1.89 & & & 0.067 & & & 21.2 \\
\hline ODP-714A, $3-5 \mathrm{~cm}$ & 16.10 & 5.38 & 5.38 & & 0.177 & 0.177 & & 28.9 \\
\hline ODP-806B, $3-5 \mathrm{~cm}$ & 27.95 & 5.84 & 5.84 & & 0.250 & 0.250 & & 10.2 \\
\hline ODP- $851 \mathrm{~B}, 8-10 \mathrm{~cm}$ & 2.69 & 5.08 & 5.08 & & 0.112 & & & 8.1 \\
\hline $\mathrm{V} 29-204,15-20 \mathrm{~cm}$ & 4.69 & 1.22 & 1.22 & & 0.018 & 0.018 & & 66.9 \\
\hline VNO-GGC37, 0-7 cm & 6.96 & 3.65 & 3.65 & & 0.078 & 0.078 & & 0.0 \\
\hline \multicolumn{9}{|l|}{ Uvigerina spp. } \\
\hline \multirow[t]{2}{*}{ All $54-9-5,0-2 \mathrm{~cm}$} & 18.27 & 4.41 & 4.20 & 0.30 & 0.231 & 0.229 & 0.003 & 16.2 \\
\hline & 20.52 & 3.99 & & & 0.227 & & & 17.8 \\
\hline \multirow[t]{2}{*}{ AII107-67GGC, $3-9 \mathrm{~cm}$} & 27.56 & 2.10 & 2.51 & 0.58 & 0.103 & 0.108 & 0.007 & 0.6 \\
\hline & 15.61 & 2.92 & & & 0.113 & & & 0.6 \\
\hline \multirow[t]{2}{*}{ AII107-69GGC, $4 \mathrm{~cm}$} & 21.14 & 1.69 & 1.68 & 0.01 & 0.086 & 0.086 & 0.000 & 0.0 \\
\hline & 23.42 & 1.68 & & & 0.086 & & & 0.0 \\
\hline \multirow[t]{3}{*}{ All107-71GGC, $5-7 \mathrm{~cm}$} & 24.11 & 3.80 & 3.27 & 0.47 & 0.120 & 0.119 & 0.001 & 0.3 \\
\hline & 27.36 & 3.08 & & & 0.119 & & & 0.7 \\
\hline & 23.74 & 2.93 & & & 0.118 & & & 0.0 \\
\hline \multirow[t]{3}{*}{ AII107-73GGC, $3-5 \mathrm{~cm}$} & 21.65 & 3.61 & 3.61 & 0.16 & 0.130 & 0.132 & 0.003 & 1.5 \\
\hline & 24.38 & 3.78 & & & 0.135 & & & 2.1 \\
\hline & 24.21 & 3.45 & & & 0.130 & & & 1.7 \\
\hline KNR73-3PC, $13-15 \mathrm{~cm}$ & 12.64 & 5.55 & 5.55 & & 0.205 & 0.205 & & 0.2 \\
\hline $\mathrm{KNR} 73-4 \mathrm{PC}, 5-7 \mathrm{~cm}$ & 2.33 & 3.49 & 3.49 & & 0.227 & & & 25.4 \\
\hline \multirow[t]{2}{*}{ ODP-658A, $18-20 \mathrm{~cm}$} & 10.44 & 1.97 & 1.68 & 0.40 & 0.092 & 0.091 & 0.002 & 3.1 \\
\hline & 17.59 & 1.40 & & & 0.089 & & & 3.0 \\
\hline \multirow[t]{3}{*}{ ODP-883D, $3-5 \mathrm{~cm}$} & 16.17 & 4.16 & 4.11 & 0.33 & 0.136 & 0.136 & 0.006 & 3.0 \\
\hline & 9.78 & 3.76 & & & 0.142 & & & 3.1 \\
\hline & 11.11 & 4.42 & & & 0.130 & & & 1.8 \\
\hline \multirow[t]{3}{*}{ RNDB-GGC1, 9-11 cm } & 15.44 & 4.10 & 3.84 & 0.23 & 0.143 & 0.135 & 0.007 & 0.0 \\
\hline & 16.91 & 3.77 & & & 0.132 & & & 0.0 \\
\hline & 14.80 & 3.66 & & & 0.131 & & & 0.0 \\
\hline VINO-BC26, 3-11 cm & 7.66 & 3.85 & 3.85 & & 0.148 & 0.148 & & 0.0 \\
\hline VINO-GGC37, $3-7 \mathrm{~cm}$ & 12.94 & 4.27 & 4.27 & & 0.157 & 0.157 & & 0.0 \\
\hline \multicolumn{9}{|l|}{ N. umbonifera } \\
\hline AII $15-765,3 \mathrm{~cm}$ & 8.73 & 2.73 & 2.73 & & 0.141 & 0.141 & & 5.0 \\
\hline AIIS4-9-5, 0-2 cm & 23.07 & 3.46 & 3.46 & & 0.230 & 0.230 & & 28.2 \\
\hline \multirow[t]{2}{*}{ AII107-124GGC, $3-5 \mathrm{~cm}$} & 20.39 & 2.40 & 2.29 & 0.15 & 0.119 & 0.117 & 0.003 & 2.9 \\
\hline & 18.62 & 2.19 & & & 0.115 & & & 3.1 \\
\hline AII107-142GGC, $3-6 \mathrm{~cm}$ & 7.64 & 2.18 & 2.18 & & 0.114 & 0.114 & & 0.0 \\
\hline \multirow[t]{3}{*}{ AII107.144GGC, 0-1 cm } & 21.61 & 2.41 & 2.40 & 0.04 & 0.147 & 0.147 & 0.002 & 5.7 \\
\hline & 16.59 & 2.44 & & & 0.149 & & & 3.4 \\
\hline & 11.21 & 2.37 & & & 0.144 & & & 1.3 \\
\hline AlI $107-147 \mathrm{GGC}, 3-5 \mathrm{~cm}$ & 20.85 & 2.02 & 2.02 & & 0.089 & 0.089 & & 3.1 \\
\hline \multirow[t]{2}{*}{ EN66-36GGC, $3-4 \mathrm{~cm}$} & 3.64 & $\underline{11.35}$ & 3.47 & & $\underline{0.217}$ & 0.109 & & 0.0 \\
\hline & 9.81 & 3.47 & & & 0.109 & & & 3.7 \\
\hline $\mathrm{KNR} 73-3 \mathrm{PC}, 13-15 \mathrm{~cm}$ & 21.09 & 4.73 & 4.73 & & 0.188 & 0.188 & & 12.1 \\
\hline \multirow[t]{2}{*}{ KNR73-4PC, $5-7 \mathrm{~cm}$} & 9.59 & 4.59 & 4.85 & 0.38 & 0.175 & 0.180 & 0.007 & 7.5 \\
\hline & 9.32 & 5.12 & & & 0.186 & & & 10.1 \\
\hline
\end{tabular}




\begin{tabular}{|c|c|c|c|c|c|c|c|c|}
\hline core, sample depth & [Ca] & $\mathrm{Zn} / \mathrm{Ca}$ & mean & std dev & $\mathrm{Cd} / \mathrm{Ca}$ & mean & std dev & $\mathrm{Mn} / \mathrm{Ca}$ \\
\hline \multirow[t]{2}{*}{ KNR110-50GGC, $0-2 \mathrm{~cm}$} & 15.98 & $\underline{2.84}$ & 1.64 & & 0.059 & 0.068 & 0.014 & 5.7 \\
\hline & 14.49 & 1.64 & & & 0.078 & & & 7.8 \\
\hline \multirow[t]{2}{*}{ KNR110-55GGC, $3 \mathrm{~cm}$} & 9.62 & 2.38 & 2.36 & 0.04 & 0.106 & 0.104 & 0.003 & 5.6 \\
\hline & 13.13 & 2.33 & & & 0.102 & & & 6.6 \\
\hline \multirow[t]{3}{*}{ KNR110-58GGC, $7 \mathrm{~cm}$} & 11.21 & $\underline{3.54}$ & 2.07 & 0.06 & 0.108 & 0.090 & 0.015 & 5.4 \\
\hline & 17.90 & $\overline{2.12}$ & & & 0.081 & & & 4.6 \\
\hline & 19.40 & 2.03 & & & 0.082 & & & 6.1 \\
\hline ODP $-851 \mathrm{~B}, 8-10 \mathrm{~cm}$ & 18.18 & 4.61 & 4.61 & & 0.193 & 0.193 & & 9.0 \\
\hline \multicolumn{9}{|l|}{ C. kullenbergi } \\
\hline AII $107-71 \mathrm{GGC}, 5-7 \mathrm{~cm}$ & 15.17 & 8.85 & 8.85 & & 0.073 & 0.073 & & 4.9 \\
\hline \multirow[t]{2}{*}{ CHN82-4PG, 0-3 cm } & 25.04 & 9.08 & 9.50 & 0.59 & 0.073 & 0.064 & 0.013 & 6.5 \\
\hline & 17.27 & 9.91 & & & 0.055 & & & 6.0 \\
\hline CHN82-11PG, $6-8 \mathrm{~cm}$ & 16.86 & 7.93 & 7.93 & & 0.062 & 0.062 & & 5.8 \\
\hline CHN82-15PC, 0-6 cm & 28.58 & 7.41 & 7.41 & & 0.084 & 0.084 & & 7.0 \\
\hline \multicolumn{9}{|l|}{ H. elegans } \\
\hline \multirow[t]{2}{*}{ AIl 107-65GGC, $1-3 \mathrm{~cm}$} & 21.87 & 0.29 & 0.29 & 0.01 & 0.026 & 0.026 & 0.000 & 0.0 \\
\hline & 22.49 & 0.28 & & & 0.026 & & & 0.0 \\
\hline \multirow[t]{2}{*}{ AII $07-67 \mathrm{GGC}, 3-9 \mathrm{~cm}$} & 28.04 & 0.60 & 0.60 & 0.01 & 0.044 & 0.045 & 0.002 & 0.0 \\
\hline & 24.44 & 0.60 & & & 0.047 & & & 0.0 \\
\hline AII107-69GGC, $4 \mathrm{~cm}$ & 22.76 & 0.43 & 0.43 & & 0.048 & 0.048 & & 0.0 \\
\hline All107-7IGGC, $5-7 \mathrm{~cm}$ & 27.70 & 0.38 & 0.38 & & 0.050 & 0.050 & & 0.1 \\
\hline \multirow[t]{2}{*}{ AII107-73GGC, $3-5 \mathrm{~cm}$} & 23.46 & 0.41 & 0.43 & 0.03 & 0.051 & 0.053 & 0.002 & 0.2 \\
\hline & 22.92 & 0.45 & & & 0.054 & & & 0.3 \\
\hline CHN82-15PC, 0-6 cm & 22.96 & 0.20 & 0.20 & & 0.027 & 0.027 & & 0.1 \\
\hline \multirow[t]{4}{*}{ DSDP-552A, $7-9 \mathrm{~cm}$} & 7.74 & $\underline{2.79}$ & 0.56 & 0.03 & $w$ & 0.040 & 0.012 & 0.0 \\
\hline & 5.41 & $\underline{3.30}$ & & & 0.036 & & & 2.4 \\
\hline & 6.44 & $\overline{0.54}$ & & & 0.031 & & & 0.0 \\
\hline & 15.36 & 0.58 & & & 0.054 & & & 0.0 \\
\hline EN66-36GGC, $3-4 \mathrm{~cm}$ & 18.87 & 0.49 & 0.49 & & 0.033 & 0.033 & & 0.0 \\
\hline KNRI10-66GGC, $7 \mathrm{~cm}$ & 28.68 & 0.29 & 0.29 & & 0.033 & 0.033 & & 0.2 \\
\hline ODP-714A, $3-5 \mathrm{~cm}$ & 23.99 & 1.61 & 1.61 & . & 0.080 & 0.080 & & 0.0 \\
\hline
\end{tabular}

Samples that are believed to be contaminated are underlined. The size cutoff for calcitic $\mathrm{Zn} / \mathrm{Ca}$ was [Ca] $=2 \mathrm{mM}$, and the cutoff for calcitic $\mathrm{Cd} / \mathrm{Ca}$ was $[\mathrm{Ca}]=3 \mathrm{mM}$; two $\mathrm{Cd} / \mathrm{Ca}$ data between 2 and $3 \mathrm{mM}$ [Ca] are italicized. For aragenitic (H. elegans) data, the size cutoff was $[\mathrm{Ca}]=4 \mathrm{mM}$. "nr" means sample was not run due to insufficient volume. 
Table 2.3. $\mathrm{Cd}$ and $\mathrm{Zn}$ partition coefficient error analysis

\begin{tabular}{|c|c|c|c|c|c|c|c|c|c|c|c|}
\hline & {$[\mathrm{P}]$} & {$[\mathrm{Cd}]_{\mathrm{sw}}$} & $\mathrm{Cd} / \mathrm{Ca}$ & $D_{\mathrm{Cd}}$ & $\Delta D_{\mathrm{Cl}}$ & & {$[\mathrm{Si}]$} & {$[\mathrm{Zn}]_{\mathrm{sw}}$} & $\mathrm{Zn} / \mathrm{Ca}$ & $D_{\mathrm{zi}}$ & $\Delta D_{\mathrm{Zu}}$ \\
\hline North Atlantic & 1.25 & 0.260 & 0.075 & 2.88 & & North Atlantic & 20 & 1.83 & 1.64 & 8.98 & \\
\hline \multirow[t]{2}{*}[\mathrm{P}]{ \pm 0.05} & 1.20 & 0.250 & 0.075 & 3.00 & 0.12 & {$[\mathrm{Si}] \pm 2$} & 18 & 1.72 & 1.64 & 9.52 & 0.54 \\
\hline & 1.30 & 0.270 & 0.075 & 2.77 & -0.11 & & 22 & 1.93 & 1.64 & 8.50 & -0.48 \\
\hline \multirow[t]{2}{*}[\mathrm{Cd}]{$_{\mathrm{sw}} \pm 0.05$} & 1.25 & 0.210 & 0.075 & 3.57 & 0.69 & {$[\mathrm{Zn}]_{\mathrm{sw}} \pm 0.3$} & 20 & 1.53 & 1.64 & 10.75 & 1.77 \\
\hline & 1.25 & 0.310 & 0.075 & 2.42 & -0.47 & & 20 & 2.13 & 1.64 & 7.71 & -1.27 \\
\hline \multirow[t]{2}{*}{$\mathrm{Cd} / \mathrm{Ca} \pm 0.007$} & 1.25 & 0.260 & 0.068 & 2.62 & -0.27 & $\mathrm{Zn} / \mathrm{Ca} \pm 0.12$ & 20 & 1.83 & 1.52 & 8.32 & -0.66 \\
\hline & 1.25 & 0.260 & 0.082 & 3.15 & 0.27 & & 20 & 1.83 & 1.76 & 9.64 & 0.66 \\
\hline \multirow[t]{2}{*}{ total $\min / \max$} & & & & 2.04 & -0.85 & total $\min / \max$ & & & & 6.57 & -2.41 \\
\hline & & & & 3.96 & 1.08 & & & & & 11.95 & 2.97 \\
\hline North Pacific & 2.60 & $0.78 \mathrm{I}$ & 0.200 & 2.56 & & North Pacific & 150 & 8.59 & 4.50 & 5.24 & \\
\hline \multirow[t]{2}{*}[P]{ \pm 0.05} & 2.55 & 0.761 & 0.200 & 2.63 & 0.07 & {$[\mathrm{Si}] \pm 2$} & 148 & 8.48 & 4.50 & 5.31 & 0.06 \\
\hline & 2.65 & 0.801 & 0.200 & 2.50 & -0.06 & & 152 & 8.69 & 4.50 & 5.18 & -0.06 \\
\hline \multirow[t]{2}{*}[\mathrm{Cd}]{$_{s w} \pm 0.05$} & 2.60 & 0.731 & 0.200 & 2.74 & 0.18 & {$[\mathrm{Zn}]_{\mathrm{SwV}} \pm 0.7$} & 150 & 7.89 & 4.50 & 5.71 & 0.47 \\
\hline & 2.60 & 0.831 & 0.200 & 2.41 & -0.15 & & 150 & 9.29 & 4.50 & 4.85 & -0.40 \\
\hline \multirow[t]{2}{*}{$\mathrm{Cd} / \mathrm{Ca} \pm 0.007$} & 2.60 & 0.781 & 0.193 & 2.47 & -0.09 & $\mathrm{Zn} / \mathrm{Ca} \pm 0.12$ & 150 & 8.59 & 4.38 & 5.10 & -0.14 \\
\hline & 2.60 & 0.781 & 0.207 & 2.65 & 0.09 & & 150 & 8.59 & 4.62 & 5.38 & 0.14 \\
\hline \multirow[t]{2}{*}{ total $\min / \max$} & & & & 2.25 & -0.31 & total $\min / \max$ & & & & 4.64 & -0.60 \\
\hline & & & & 2.89 & 0.33 & & & & & 5.91 & 0.67 \\
\hline
\end{tabular}

Rows labeled North Atlantic and North Pacific are typical values for each region. Seawater [P] and [Si] uncertainties are based on scatter amongst similar depths from "nearby" GEOSECS stations. Seawater [Cd] and [Zn] uncertainties are based on the scatter in the global Cd:P (Boyle, 1988a) and Zn:Si relationships. Foraminiferal $\mathrm{Cd} / \mathrm{Ca}$ and $\mathrm{Zn} / \mathrm{Ca}$ uncertainties are average standard deviations of replicates from this study. Minimum and maximum totals are aggregates of all uncertainties. $\Delta D$ is the difference from the "correct" value. 
Table 2.4. Data from KNR159-5 multicores

\begin{tabular}{lrrrrr}
\hline \multicolumn{1}{l}{ core } & depth & {$[\mathrm{Ca}]$} & $\mathrm{Zn} / \mathrm{Ca}$ & $\mathrm{Cd} / \mathrm{Ca}$ & $\mathrm{Mn} / \mathrm{Ca}$ \\
\hline $\begin{array}{l}\text { C. } \text { wuellerstorfi } \\
\text { MC15 }\end{array}$ & 1604 & 28.10 & 1.62 & 0.058 & 23.9 \\
MC32 & 2096 & 18.83 & 1.62 & 0.039 & 19.0 \\
MC72 & 2397 & 22.06 & 1.19 & 0.049 & 9.3 \\
& & 17.38 & 1.32 & 0.037 & 9.0 \\
MC18 & 2971 & 28.40 & 1.80 & 0.057 & 8.4 \\
MC117 & 3356 & 19.90 & 3.78 & 0.123 & 7.9 \\
& & 13.25 & 3.64 & 0.122 & 7.0 \\
& & $* 8.48$ & $* 3.19$ & $* 0.075$ & $* 19.5$ \\
MC123 & 3581 & 23.23 & 3.34 & 0.116 & 10.0 \\
& & 21.71 & 3.31 & 0.108 & 11.6 \\
& & $* 11.03$ & $* 3.21$ & $* 0.099$ & $* 11.2$ \\
MC47 & 3700 & 18.89 & 3.31 & 0.123 & 7.2 \\
MC25 & 3885 & 9.85 & 2.80 & 0.090 & 16.2 \\
& & $* 3.82$ & $* 4.07$ & $* 0.112$ & $* 11.5$
\end{tabular}

N. umbonifera

\begin{tabular}{lrrrrr} 
MC117 & 3356 & 20.35 & 2.40 & 0.114 & 1.4 \\
& & $* 14.58$ & $* 2.03$ & $* 0.087$ & $* 5.2$ \\
MC123 & \multirow{2}{*}{3581} & 23.42 & 2.63 & 0.126 & 4.6 \\
& & $* 10.49$ & $* 2.17$ & $* 0.117$ & $* 2.8$ \\
MC25 & 3885 & 12.64 & 2.45 & 0.133 & 5.0 \\
& & $* 3.30$ & $* 2.26$ & $* 0.092$ & $* 0.0$ \\
\hline
\end{tabular}

All samples are from $0-1 \mathrm{~cm}$ depth interval. Data with asterisks are from Rose Bengal stained ("live") foraminifera. 


\title{
Chapter 3. Glacial-interglacial records of benthic foraminiferal $\mathrm{Zn} / \mathrm{Ca}$ and $\mathrm{Cd} / \mathrm{Ca}$ from the deep eastern equatorial Pacific: constraints on oceanic carbonate ion concentrations
}

\begin{abstract}
Zn} / \mathrm{Ca}$ and $\mathrm{Cd} / \mathrm{Ca}$ ratios in the benthic foraminifer Cibicidoides wuellerstorfi exhibit large fluctuations over the past 100,000 years in a deep $(3851 \mathrm{~m})$ eastern equatorial Pacific sediment core. This variability is too large to have resulted from deep circulation changes alone, but can be explained by changes in bottom water saturation state with respect to calcite $\left(\Delta \mathrm{CO}_{3}{ }^{2-}\right)$. Assuming that bottom water dissolved $\mathrm{Zn}$ and $\mathrm{Cd}$ concentrations remained constant, $\mathrm{Zn} / \mathrm{Ca}$ and $\mathrm{Cd} / \mathrm{Ca}$ imply that $\mathrm{CO}_{3}{ }^{2-}$ concentrations were lowest during glacial Marine Isotope Stage 4 and highest during the last deglaciation (Termination I). Last glacial maximum $\mathrm{CO}_{3}{ }^{2-}$ concentrations appear to have been within a few $\mu \mathrm{mol} \mathrm{kg}^{-1}$ of modern values. This overall pattern is consistent with a " $\mathrm{CaCO}_{3}$ compensation" mechanism for lowering glacial atmospheric $\mathrm{CO}_{2}$ concentrations, and argues against a large steady state increase in glacial $\mathrm{pH}$.
\end{abstract}

\section{Introduction}

Atmospheric $\mathrm{CO}_{2}$ and the carbonate system in seawater

Analysis of air trapped in Antarctic ice cores indicates that atmospheric $\mathrm{CO}_{2}$ concentrations have varied dramatically over the past glacial-interglacial cycle (Delmas $e t$ al., 1980; Barnola et al., 1987). During the last glacial maximum (LGM), $\mathrm{CO}_{2}$ was 190 parts per million by volume (ppmv) (Barnola et al., 1987), compared to 280 ppmv in the pre-industrial atmosphere (Neftel et al., 1985) and $\sim 365$ ppmv today (after Keeling and Whorf, 1994). Nearly all of the models proposed to explain the glacial difference call upon a transfer of $\mathrm{CO}_{2}$ from the atmosphere into the ocean (see Broecker and Henderson, 1998, for a review).

Many of these models also call for changes in deep ocean carbonate ion $\left(\mathrm{CO}_{3}{ }^{2-}\right)$ concentrations and $\mathrm{CaCO}_{3}$ preservation via the mechanism of $\mathrm{CaCO}_{3}$ compensation (Broecker and Peng, 1987). This is accomplished by transferring dissolved inorganic carbon (DIC or $\Sigma \mathrm{CO}_{2}$ ) from the upper ocean to the deep ocean (either to deep waters or to sediment pore waters). $\Sigma \mathrm{CO}_{2}$ is defined as:

$$
\Sigma \mathrm{CO}_{2}=\left[\mathrm{CO}_{2}\right]+\left[\mathrm{HCO}_{3}{ }^{-}\right]+\left[\mathrm{CO}_{3}{ }^{2-}\right]
$$


where $\left[\mathrm{CO}_{2}\right]$ represents the sum of $\left[\mathrm{CO}_{2}(\mathrm{aq})\right]$ and $\left[\mathrm{H}_{2} \mathrm{CO}_{3}\right]$, the latter of which is negligible. At the $\mathrm{pH}$ of seawater, most of the added $\mathrm{\Sigma CO}_{2}$ will become bicarbonate $\left(\mathrm{HCO}_{3}{ }^{-}\right)$. However, the speciation of the entire $\Sigma \mathrm{CO}_{2}$ pool (along with boron) must maintain a charge balance with the excess cations in seawater $\left(\mathrm{Na}^{+}, \mathrm{K}^{+}, \mathrm{Mg}^{2+}, \mathrm{Ca}^{2+}\right.$, etc., whose combined charge exceeds that of $\mathrm{Cl}^{-}, \mathrm{SO}_{4}{ }^{2-}, \mathrm{Br}^{-}$, etc.). The magnitude of this balance is the alkalinity:

$$
\mathrm{Alk} \approx\left[\mathrm{HCO}_{3}^{-}\right]+2\left[\mathrm{CO}_{3}{ }^{2-}\right]+\left[\mathrm{B}(\mathrm{OH})_{4}^{-}\right]
$$

Since the alkalinity must remain constant in the face of added $\mathrm{HCO}_{3}{ }^{-}$, some of the existing $\mathrm{CO}_{3}{ }^{2-}$ also gets converted to $\mathrm{HCO}_{3}{ }^{-}$. The drop in $\left[\mathrm{CO}_{3}{ }^{2-}\right]$ promotes dissolution of $\mathrm{CaCO}_{3}$, which is largely controlled by the saturation state of overlying bottom water, defined by:

$$
\Delta \mathrm{CO}_{3}{ }^{2-}=\left[\mathrm{CO}_{3}{ }^{2-}\right]_{\text {in situ }}-\left[\mathrm{CO}_{3}{ }^{2-}\right]_{\text {saturation }}
$$

(e.g., Broecker and Peng, 1982). This dissolution raises whole-ocean alkalinity (due to added $\mathrm{Ca}^{2+}$ ) and $\Sigma \mathrm{CO}_{2}$ in a 2:1 ratio, shifting the $\Sigma \mathrm{CO}_{2}$ equilibrium away from $\mathrm{CO}_{2}(\mathrm{aq})$ and towards $\mathrm{CO}_{3}{ }^{2-}$ until a new steady state is reached. The resulting decrease in $p \mathrm{CO}_{2}$ thus causes atmospheric $\mathrm{CO}_{2}$ concentrations to drop.

According to this model, if the $\Sigma \mathrm{CO}_{2}$ is initially added to deep waters (for example, by increasing the fraction of biological productivity that is exported to the deep ocean; Boyle, 1988b), then steady state $\left[\mathrm{CO}_{3}{ }^{2-}\right]$ during the LGM would not be much different than today, despite increased alkalinity. Significant $\left[\mathrm{CO}_{3}{ }^{2-}\right]$ changes would only be transient, occurring at glacial-interglacial boundaries (lows at the beginnings of glacials, highs at terminations) and lasting no more than a few thousand years (Figure 3.1). To a first order, paleo- $\left[\mathrm{CO}_{3}{ }^{2-}\right]$ can be estimated by examining past patterns of $\mathrm{CaCO}_{3}$ preservation at the seafloor (lysocline reconstructions). This exercise suggests that LGM $\left[\mathrm{CO}_{3}{ }^{2-}\right]$ was on the order of 5 to $10 \mu \mathrm{mol} \mathrm{kg}{ }^{-1}$ higher than today in the deep Pacific, and $\sim 10 \mu \mathrm{mol} \mathrm{kg-1}$ lower than today in the deep Atlantic (e.g., Farrell and Prell, 1989; Broecker, 1995). These estimates are therefore not inconsistent with an addition of $\mathrm{\Sigma CO}_{2}$ to the deep ocean, with differences between the Atlantic and Pacific being caused mainly 
by changes in deep circulation (Boyle, 1988b). Although it is difficult to make quantitative $\left[\mathrm{CO}_{3}{ }^{2-}\right]$ estimates for shorter time intervals, there is ample evidence of a $\mathrm{CaCO}_{3}$ preservation event during the last deglaciation or early Holocene (e.g., Berger, 1977; Berger and Keir, 1984, 1985; Broecker et al., 1991; Berelson et al., 1997).

A somewhat different picture arises if the $\Sigma \mathrm{CO}_{2}$ is added to sediment pore waters. Complicating the relationship between $\mathrm{CaCO}_{3}$ preservation and deep water $\left[\mathrm{CO}_{3}{ }^{2-}\right]$ is the fact that organic matter degradation within the sediment may cause significant $\mathrm{CaCO}_{3}$ dissolution (even under supersaturated bottom waters) by adding $\mathrm{CO}_{2}$ to pore waters (e.g., Emerson and Bender, 1981; Archer et al., 1989; Jahnke et al., 1994; Martin and Sayles, 1996; Hales and Emerson, 1997). Archer and Maier-Reimer (1994) suggested that a glacial increase in the ratio of $\mathrm{C}_{\text {org }}: \mathrm{CaCO}_{3}$ production would drive more dissolution within sediments. The increased dissolution would raise seawater alkalinity, resulting in a rise in $\left[\mathrm{CO}_{3}{ }^{2-}\right]$ and a drop in $p \mathrm{CO}_{2}$. The steady state of this model is reached when deep water $\left[\mathrm{CO}_{3}{ }^{2-}\right]$ is sufficiently high (more than $50 \mu \mathrm{mol} \mathrm{kg}{ }^{-1}$ higher than today) to balance the excess dissolution being driven by respiratory $\mathrm{CO}_{2}$ (Figure 3.1). The result is little net change in steady state $\mathrm{CaCO}_{3}$ preservation, in agreement with sedimentary records. Sanyal et al. (1995) used benthic foraminiferal boron isotopes $\left(\delta^{11} \mathrm{~B}\right)$ to suggest that the $\mathrm{pH}$ of the deep ocean was $0.3 \pm 0.1$ units higher during the LGM than today. Such a large shift, which is enough to explain the entire glacial atmospheric $\mathrm{CO}_{2}$ drop, requires an increase in deep water $\left[\mathrm{CO}_{3}{ }^{2-}\right]$ of $\sim 100 \mu \mathrm{mol} \mathrm{kg}{ }^{-1}$. Sanyal et al. (1995) called upon Archer and Maier-Reimer's (1994) "rain ratio" hypothesis to explain why this $\left[\mathrm{CO}_{3}{ }^{2-}\right]$ increase was not accompanied by a major deepening of the lysocline.

Model results of Sigman et al. (1998), however, imply that no reasonable increase in initial $\mathrm{C}_{\text {org }}: \mathrm{CaCO}_{3}$ rain ratio can significantly separate the sedimentary lysocline from the calcite saturation horizon. Rather, the proportion of organic matter escaping remineralization in the water column must be increased such that the rain ratio at the seafloor, at all depths below $1500 \mathrm{~m}$, is raised to about 2 ( two to four times modern values). Even a modest decrease of the rain ratio with depth results in a relatively strong 
coupling of the lysocline to the saturation horizon. Sigman et al. (1998) thus concluded that the glacial scenarios proposed by Archer and Maier-Reimer (1994) and Sanyal et al. (1995) are unlikely, though no explanation has been offered as to why $\delta^{11} \mathrm{~B}$ might not reflect paleo-pH.

\section{Constraining paleo- $\mathrm{CO}_{3}{ }^{2-}$ using deep Pacific $\mathrm{Zn} / \mathrm{Ca}$ and $\mathrm{Cd} / \mathrm{Ca}$}

The concentrations of $\mathrm{Zn}$ and $\mathrm{Cd}$ in benthic foraminiferal calcite depend on (1) bottom water dissolved $\mathrm{Zn}$ and $\mathrm{Cd}$ concentrations, and (2) bottom water $\Delta \mathrm{CO}_{3}{ }^{2-}$ with respect to calcite (see Chapter 2). In theory then, deep ocean paleo- $\Delta \mathrm{CO}_{3}{ }^{2-}$ could be estimated if seawater [ $\mathrm{Zn}]$ and [Cd] were independently constrained. Since deep ocean circulation is an important influence on bottom water $[\mathrm{Zn}]$ and $[\mathrm{Cd}]$, the ideal study area would be in a region where deep circulation has been relatively constant over the past glacial-interglacial cycle. Although this is a difficult criterion to meet with great certainty, a promising area is the deep eastern tropical Pacific. Duplessy et al. (1988) compiled LGM Cibicidoides $\delta^{13} \mathrm{C}$ data from the north and equatorial Pacific. They concluded that below $\sim 2600 \mathrm{~m}, \delta^{13} \mathrm{C}$ was lower than modern GEOSECS measurements by $\sim 0.3 \%$, a value indistinguishable from the LGM mean ocean isotopic shift of $\sim 0.32 \%$. Herguera et al. (1992) calculated an LGM decrease of $0.44 \%$ (relative to core tops) in the western tropical Pacific below $2000 \mathrm{~m}$ (see McCorkle and Keigwin [1994] for validation of the core top data), and Keigwin (1998) found a difference of $-0.45 \%$ (relative to core tops) in the high-latitude northwest Pacific below $2000 \mathrm{~m}$. Together these studies suggest that the nutrient content of the deep Pacific, and by extension deep Pacific circulation, were not much different than today. It is reasonable to assume that if circulation did not change appreciably between the LGM and Holocene, then circulation during marine isotope stages (MIS) 3, 4, and 5 was also relatively unchanged. Indeed, deep Pacific $\delta^{13} \mathrm{C}$ records spanning this period are often interpreted as representing mean-ocean isotopic shifts (e.g., Shackleton et al., 1983). 
The leap from $\delta^{13} \mathrm{C}$ to circulation requires that the $\delta^{13} \mathrm{C}$ signature of deep waters entering the glacial South Pacific was not altered by "upstream" changes in circulation, biological cycling, or air-sea exchange. This is not a simple issue to evaluate, because many glacial Southern Ocean $\delta^{13} \mathrm{C}$ data are believed to be strongly biased towards low values by a productivity artifact (Mackensen et al., 1993; Matsumoto and Lynch-Stieglitz, 1999), and corresponding $\mathrm{Cd} / \mathrm{Ca}$ data may be affected by undersaturation with respect to calcite (McCorkle et al., 1995). Matsumoto and Lynch-Stieglitz (1999) argued that the true LGM deep Southern Ocean $\delta^{13} \mathrm{C}$ value must have been close to $-0.2 \%$, a value common to all three sectors. This is still roughly $0.7 \%$ lower than the Southern Ocean today, and close to the LGM eastern equatorial Pacific value. This implies less "aging" of southern source waters as they filled the glacial Pacific, either due to more rapid transit or to a decreased addition of remineralized organic matter. Thus the $\delta^{13} \mathrm{C}$ evidence for unchanging nutrient contents in the deep Pacific may not equate with unchanging circulation. However, as long as $\delta^{13} \mathrm{C}$ remained coupled to nutrients, such circulation changes would have had little effect on eastern equatorial Pacific seawater $\mathrm{Zn}$ and $\mathrm{Cd}$ concentrations. LGM Cd/Ca in this region appears to be slightly lower than today (Boyle, 1992), though some of these data may also be affected by undersaturation with respect to calcite. In conclusion, the assumption that deep eastern equatorial Pacific $\mathrm{Zn}$ and $\mathrm{Cd}$ concentrations were not significantly altered by changes in circulation or upstream biological cycling is not very well constrained, but it serves as a useful starting point.

Changes in the global oceanic inventories of $\mathrm{Zn}$ and $\mathrm{Cd}$ represent an additional source of potential variability in the deep eastern tropical Pacific. The main natural sources of dissolved $\mathrm{Zn}$ into the oceans are believed to be rivers $\left(\sim 0.1-0.15 \mathrm{Gmol} \mathrm{yr}^{-1}\right.$, assuming an average riverine concentration of $3 \mathrm{nmol} \mathrm{kg}^{-1}$ and a possible $50 \%$ estuarine increase; Shiller and Boyle, 1985), aeolian ( 0.1-0.7 Gmol yr-1, assuming a total $\mathrm{Zn}$ deposition of 0.7-4 Gmol $\mathrm{yr}^{-1}$, a $76 \%$ solubility, and a non-anthropogenic fraction of $25 \%$; Duce et al., 1991), and high-temperature hydrothermal ( $\sim 0.1-0.25 \mathrm{Gmol} \mathrm{yr}^{-1}$, assuming an average black smoker concentration of $50 \mu \mathrm{mol} \mathrm{kg}-1$ [Edmond et al., 1995], a water flux of 18-49 
Pg $\mathrm{yr}^{-1}$ [Mottl et al., 1994], and a 90\% precipitation and burial as sulfide minerals [unconstrained; see Feely et al., 1994]). Assuming a mean ocean dissolved $\mathrm{Zn}$ concentration of $6 \mathrm{nmol} \mathrm{kg}^{-1}$, the sum of all these inputs implies an oceanic residence time of $\sim 8,000$ to 28,000 years. If the major output of $\mathrm{Zn}$ is burial with biogenic debris, and $\sim 95 \%$ of the sinking $\mathrm{Zn}$ flux (Collier and Edmond, 1984) is remineralized in the water column and at the seafloor (in analogy to $\mathrm{Si}$ ), then the resulting residence time is $\sim 11,000$ to 34,000 years. Both of these estimates, although very poorly constrained, suggest that glacial-interglacial $\mathrm{Zn}$ inventory changes cannot be ruled out. $\mathrm{Cd}$ is believed to have a slightly longer residence time, assuming that aeolian and hydrothermal inputs are minor (Boyle et al., 1976). By compiling Cd/Ca data from various ocean basins, Boyle (1992) estimated that the LGM ocean contained perhaps $13 \%$ less $\mathrm{Cd}$ than today, though the probable error is of the same order as the estimate. In addition, Boyle's (1992) compilation does not account for possible changes in $\mathrm{ACO}_{3}{ }^{2-}$ and its effect on $\mathrm{Cd}$ partition coefficients. In the absence of compelling data to the contrary, I will begin with (and later attempt to evaluate) the assumption that oceanic $\mathrm{Zn}$ and $\mathrm{Cd}$ inventories have remained relatively constant over the past glacial-interglacial cycle.

\section{Study area and previous stable isotope work}

ODP Site 849 is located at $0^{\circ} 11^{\prime} \mathrm{N}, 110^{\circ} 31^{\prime} \mathrm{W}$, and $3851 \mathrm{~m}$ water depth on the western flank of the East Pacific Rise (Figure 3.2). Mix et al. (1995) argued that this site is ideally situated to monitor average deep Pacific water chemistry through time. The potential temperature $\left(1.2^{\circ} \mathrm{C}\right)$, salinity $(34.68 \%)$, and oxygen concentration $(155 \mu \mathrm{mol}$ $\left.\mathrm{kg}^{-1}\right)$ of waters bathing this site today are indeed characteristic of average deep Pacific water (Lonsdale, 1976; Mix et al., 1995). The modern dissolved $\mathrm{Zn}$ concentration, estimated from Si measurements at GEOSECS Station 334 (Broecker et al., 1982) using Equation 2.1, is $8.5 \mathrm{nmol} \mathrm{kg}^{-1}$ (Figure 3.3). The modern Cd concentration, estimated from

GEOSECS Station $334 \mathrm{P}$ using Equation 2.3 (Boyle, 1988a), is $0.70 \mathrm{nmol} \mathrm{kg}^{-1}$ (Figure 3.3). Bottom waters at this site are slightly undersaturated with respect to calcite, with a 
modern $\Delta \mathrm{CO}_{3}{ }^{2-}$ (also estimated using GEOSECS Station 334) of $-4 \mu \mathrm{mol} \mathrm{kg}{ }^{-1}$ (Figure 3.4; see Appendix 2 for equations). Predicted $\mathrm{Zn}$ and $\mathrm{Cd}$ partition coefficients (Equations 2.6, 2.12 ) are therefore 4.6 and 2.1 , respectively, yielding predicted core top values of $\mathrm{Zn} / \mathrm{Ca}=$ $3.9 \mu \mathrm{mol} \mathrm{mol}^{-1}$ and $\mathrm{Cd} / \mathrm{Ca}=0.15 \mu \mathrm{mol} \mathrm{mol}^{-1}$.

Mix et al. (1995) measured $\delta^{18} \mathrm{O}$ and $\delta^{13} \mathrm{C}$ in the benthic foraminifera Cibicidoides wuellerstorfi and Uvigerina peregrina $(>150 \mu \mathrm{m}$ ) (Figure 3.5). The maximum HoloceneLGM $\delta^{18} \mathrm{O}$ amplitude is $1.61 \%$, and the core top-LGM amplitude is $1.26 \%$. Termination II lies at $408 \mathrm{~cm}$ composite depth, indicating an average sedimentation rate of $3.2 \mathrm{~cm} \mathrm{kyr}^{-1}$ over the past $125 \mathrm{kyr}$. Holocene $C$. wuellerstorfi $\delta^{13} \mathrm{C}$ values $(0.16 \pm 0.07 \%$ o $)$ agree reasonably well with modern seawater values ( $\sim 0.05 \%$; Kroopnick, 1974$)$ given an average C. wuellerstorfi offset of $0.07 \pm 0.15 \%$ relative to seawater (Duplessy et al., 1984). The maximum Holocene-LGM $\delta^{13} \mathrm{C}$ amplitude is $-0.47 \%$, and the mean HoloceneLGM amplitude is $-0.42 \%$. Both values are reasonably close to the mean ocean shift of $\sim 0.32 \%$ (Duplessy et al., 1988) and consistent with Mix et al.'s (1995) interpretation of ODP $849 \delta^{13} \mathrm{C}$ as a global average record. Although it has been suggested that benthic foraminiferal $\delta^{13} \mathrm{C}$ may also be affected by $\Delta \mathrm{CO}_{3}{ }^{2 *}$ (McCorkle et al., 1995, 1999), the relationship is poorly understood and no correction will be attempted.

\section{Materials and methods}

Sediment cores from ODP Site 849 (Holes B and C) were sampled at approximately $10 \mathrm{~cm}$ intervals. Sample depths were converted to shore-based composite depth (rmcd) and will be given here in cm (Hagelberg et al., 1995). $\mathrm{Zn}, \mathrm{Cd}$, and $\mathrm{Mn}$ concentrations were measured in shells of the benthic foraminifera $C$. wuellerstorfi, Nutallides umbonifera, and Uvigerina spp. Emphasis was placed on C. wuellerstorfi, whose abundances afforded the most complete record (Figure 3.6). Each sample consisted of $\sim 5$ to 15 individuals $(>250 \mu \mathrm{m}$ ), and was cleaned following the methods of Boyle and Keigwin (1985/86) as modified by Rosenthal (1994) and Boyle and Rosenthal (1996). Additional precautions were taken to minimize the risk of laboratory contamination, which 
has historically been a major obstacle to $\mathrm{Zn}$ work (Bruland et al., 1978). $\mathrm{Zn}, \mathrm{Cd}$, and $\mathrm{Mn}$ were measured sequentially by graphite furnace atomic absorption spectrophotometry (AAS) and Ca was measured by flame AAS, all on a Hitachi Z-8200. Analytical precision, based on frequent analyses of three consistency standards, is $\pm 2-3 \%$ for $\mathrm{Zn}, \pm 3-6 \%$ for $\mathrm{Cd}$, $\pm 8-9 \%$ for $\mathrm{Mn}$, and $\pm 1 \%$ for $\mathrm{Ca}$ (see Appendix 1 for further details on analytical methods and precision).

New $\delta^{18} \mathrm{O}$ and $\delta^{13} \mathrm{C}$ measurements were made on single shells of $C$. wuellerstorfi (>250 $\mu \mathrm{m}$ ) from several intervals in ODP 849, using a Finnigan MAT 252 mass spectrometer with a "Kiel" automated carbonate device. Conversion to PDB is through the intermediate standard NBS-19, and analytical precision is $\pm 0.03 \%$ for $\delta^{13} \mathrm{C}$ and $\pm 0.07 \%$ for $\delta^{18} \mathrm{O}$.

Finally, planktonic foraminiferal fragmentation was measured in the upper portion of the core following the counting methods of Le et al. (1995), which assume that a whole foraminifer is likely to be broken into about eight fragments.

\section{Results and discussion}

$\mathrm{Mn} / \mathrm{Ca}$ and possible authigenic contamination

Boyle (1983) showed that $\mathrm{Mn} / \mathrm{Ca}$ ratios of cleaned foraminifera are elevated in sediments whose pore waters contain reduced $\mathrm{Mn}^{2+}(\mathrm{aq})$. He proposed that $\mathrm{Mn}$ is incorporated into manganese carbonate $\left(\mathrm{CaMn}\left(\mathrm{CO}_{3}\right)_{2}\right)$ overgrowths that can be only partially removed by dissolution with a weak acid (the final step of the cleaning process). These overgrowths may contain high levels of trace elements, or prevent the removal of clay and iron oxide contaminants. Boyle (1983) noted that Cd contamination appears to be negligible when $\mathrm{Mn} / \mathrm{Ca}$ is below $10^{-4}$ (order $100 \mu \mathrm{mol} \mathrm{mol}^{-1}$ ). Because many of the ODP 849 benthic foraminiferal $\mathrm{Mn} / \mathrm{Ca}$ values are above this level, I will examine the possibility of authigenic $\mathrm{Cd}$ and $\mathrm{Zn}$ contamination before interpreting the $\mathrm{Cd} / \mathrm{Ca}$ and $\mathrm{Zn} / \mathrm{Ca}$ records.

Mayer et al. (1992) identified the visual redox boundary (color change from brown to green) at $\sim 400 \mathrm{~cm}$ in ODP 849 . This boundary is close to a sharp increase in the $\mathrm{Mn} / \mathrm{Ca}$ 
ratios of C. wuellerstorfi, N. umbonifera, and Uvigerina spp. (Figure 3.7). Above $\sim 370$ $\mathrm{cm}$, the means for each species are 249,176 , and $61 \mu_{\mathrm{mol} \mathrm{mol}}^{-1}$, respectively, while below $370 \mathrm{~cm}$ the means are 587,490 , and $325 \mu \mathrm{mol} \mathrm{mol}-1$. Despite these high values, two lines of evidence suggest that the $\mathrm{Cd} / \mathrm{Ca}$ values are not significantly contaminated. First, four of the seven lowest $C$. wuellerstorfi $\mathrm{Cd} / \mathrm{Ca}$ ratios in the core occur below the redox boundary, with a mean value of $0.134 \mu \mathrm{mol} \mathrm{mol}-1$ and a mean $\mathrm{Mn} / \mathrm{Ca}$ of $548 \mu \mathrm{mol} \mathrm{mol}^{-1}$ (Figure 3.8). The $\mathrm{Cd} / \mathrm{Ca}$ of these data is lower than any deep eastern equatorial Pacific glacial or Holocene value reported by Boyle (1992). Similarly, the LGM C. wuellerstorfi $\mathrm{Cd} / \mathrm{Ca}$ mean $\left(0.162 \mu \mathrm{mol} \mathrm{mol}^{-1}\right)$ is the lowest yet observed for this region. Second, since the C. wuellerstorfi and $N$. umbonifera contain about two to five times as much $\mathrm{Mn}$ as the Uvigerina, any contamination should be more severe for the former two species. Instead, Uvigerina $\mathrm{Cd} / \mathrm{Ca}$ values are often the highest of the three (Figure 3.8). Correlations between $\mathrm{Cd} / \mathrm{Ca}$ and $\mathrm{Mn} / \mathrm{Ca}$ are insignificant for $C$. wuellerstorfi and Uvigerina but significant for $N$. umbonifera (Figure 3.9), though such analyses cannot completely refute nor confirm the presence of contamination.

The possibility of significant $\mathrm{Zn}$ contamination is harder to evaluate because there are no other pre-Holocene Pacific $\mathrm{Zn} / \mathrm{Ca}$ data available for comparison. A plot of $\mathrm{Zn} / \mathrm{Ca}$ vs. $\mathrm{Mn} / \mathrm{Ca}$ shows a significant correlation for C. wuellerstorfi but not for $N$. umbonifera or Uvigerina (Figure 3.9). The C. wuellerstorfi correlation is dominated by samples with $\mathrm{Mn} / \mathrm{Ca}$ greater than $500 \mu \mathrm{mol} \mathrm{mol}^{-1}$ (samples below the redox boundary). The correlation decreases dramatically $\left(r^{2}=0.001\right)$ if only data shallower than $370 \mathrm{~cm}$ are considered. The sawtooth fluctuations in C. wuellerstorfi $\mathrm{Zn} / \mathrm{Ca}$ and $\mathrm{Mn} / \mathrm{Ca}$ below this boundary look suspiciously similar (Figures $3.7,3.8$ ), and it is likely that these samples are contaminated. Another feature of the C. wuellerstorfi $\mathrm{Zn} / \mathrm{Ca}$ record shared by $\mathrm{Mn} / \mathrm{Ca}$ is the low at 211 to $227 \mathrm{~cm}$, which is also seen in $\mathrm{Cd} / \mathrm{Ca}$. I propose that in this case, however, the $\mathrm{Mn} / \mathrm{Ca}$ low is an indirect consequence of the same conditions that produced the $\mathrm{Zn} / \mathrm{Ca}$ and $\mathrm{Cd} / \mathrm{Ca}$ lows, i.e., bottom water undersaturation with respect to calcite (discussed below). These two samples were extremely friable, as expected by severe undersaturation, and large 
fractions of their mass were lost during the cleaning process. Since manganese carbonate occurs as a surface phase, it is probable that its removal during the cleaning was more complete than for surrounding samples, resulting in relatively low $\mathrm{Mn} / \mathrm{Ca}$ ratios. Under this scenario, the $\mathrm{Mn} / \mathrm{Ca}$ record, unlike the $\mathrm{Zn} / \mathrm{Ca}$ and $\mathrm{Cd} / \mathrm{Ca}$ records, is overprinted with a cleaning artifact.

Due to the probability of contamination below the redox boundary, I will restrict my interpretations of $\mathrm{Zn} / \mathrm{Ca}$ (and $\mathrm{Cd} / \mathrm{Ca}$ ) to the upper $370 \mathrm{~cm}$ of the core. Although I cannot rule out authigenic contamination above $370 \mathrm{~cm}$, I assume that it is small in magnitude compared to fluctuations in lattice-bound $\mathrm{Zn}$ and $\mathrm{Cd}$. Note that previous $\mathrm{Cd} / \mathrm{Ca}$ studies have accepted data with $\mathrm{Mn} / \mathrm{Ca}$ values above $200 \mu \mathrm{mol} \mathrm{mol}^{-1}$ (Adkins et al., 1997; Martin and Lea, 1998).

\section{$\mathrm{Zn} / \mathrm{Ca}$ and $\mathrm{Cd} / \mathrm{Ca}$ in $\mathrm{C}$. wuellerstorfi}

Of the three species analyzed in ODP $849, C$. wuellerstorfi gives the most complete record (Figure 3.6). This is fortunate because the relationships between $D_{\mathrm{Zn}}$, $D_{\mathrm{Cd}}$, and $\Delta \mathrm{CO}_{3}{ }^{2-}$ are best defined for C. wuellerstorfi. Both $\mathrm{Zn} / \mathrm{Ca}$ and $\mathrm{Cd} / \mathrm{Ca}$ span a large range of values in this core (above $370 \mathrm{~cm}$ ), from 3.61 to $7.85 \mu \mathrm{mol} \mathrm{mol}^{-1}$ for $\mathrm{Zn} / \mathrm{Ca}$ and from 0.121 to $0.261 \mu \mathrm{mol} \mathrm{mol}-1$ for $\mathrm{Cd} / \mathrm{Ca}$ (Figure 3.10, Table 3.1). If these values were interpreted in terms of constant partition coefficients, they would correspond to an improbable range of seawater nutrient contents. A reasonable estimate of the $\delta^{13} \mathrm{C}$ variability associated with nutrient changes (the residual after removing mean ocean $\delta^{13} \mathrm{C}$ changes) is $\pm 0.1 \%$. Using the modern relationships between the various nutrients, this corresponds to a P range of about $\pm 0.09 \mu \mathrm{mol} \mathrm{kg}-1$ (Broecker and Maier-Reimer, 1992), a $\mathrm{Cd}$ range of about $\pm 0.04 \mathrm{nmol} \mathrm{kg}^{-1}$ (Boyle, 1988a), and a $\mathrm{Zn}$ range of about $\pm 0.9 \mathrm{nmol}$ $\mathrm{kg}^{-1}$ (assuming a proportionality to $\mathrm{Cd}$ as observed in the modern Pacific). Applying a $D_{\mathrm{Zn}}$ of 4.6 and a $D_{\mathrm{Cd}}$ of 2.1 (as predicted from modern $\Delta \mathrm{CO}_{3}{ }^{2-}$ ), these values translate into $\pm 0.4 \mu \mathrm{mol} \mathrm{mol}^{-1} \mathrm{Zn} / \mathrm{Ca}$ and $\pm 0.008 \mu \mathrm{mol} \mathrm{mol}^{-1} \mathrm{Cd} / \mathrm{Ca}$ (dashed lines in Figure 3.10), 
ranges much smaller than observed in the core. It is clear that the $\mathrm{Zn} / \mathrm{Ca}$ and $\mathrm{Cd} / \mathrm{Ca}$ records are dominated by processes other than circulation-induced nutrient changes.

Nearly the entire magnitude of the $\mathrm{Zn} / \mathrm{Ca}$ and $\mathrm{Cd} / \mathrm{Ca}$ fluctuations can, however, be explained by allowing partition coefficients to change in response to $\Delta \mathrm{CO}_{3}{ }^{2-}$, even if seawater $\mathrm{Zn}$ and $\mathrm{Cd}$ concentrations are held constant. The modern $\mathrm{Zn} / \mathrm{Ca}$ and $\mathrm{Cd} / \mathrm{Ca}$ values predicted from GEOSECS $\mathrm{Si}, \mathrm{P}$, and $\Delta \mathrm{CO}_{3}{ }^{2-}$ data, shown as open squares in Figure 3.10, are close to the lowest values observed in the core. The decreasing trends through the mid to late Holocene fall slightly short of these predicted values, suggesting that the latest Holocene is missing (as expected for an ODP core). The highest possible $\mathrm{Zn} / \mathrm{Ca}$ and $\mathrm{Cd} / \mathrm{Ca}$ values, assuming constant seawater $\mathrm{Zn}$ and $\mathrm{Cd}$ concentrations, are shown in Figure 3.10 as hatched squares. These numbers correspond to the maximum partition coefficients of $D_{\mathrm{Zn}}=9\left(\Delta \mathrm{CO}_{3}{ }^{2-} \geq 25 \mu \mathrm{mol} \mathrm{mol}{ }^{-1}\right)$ and $D_{\mathrm{Cd}}=3\left(\Delta \mathrm{CO}_{3}{ }^{2-} \geq 5 \mu \mathrm{mol}\right.$ $\mathrm{mol}^{-1}$ ). Only one point, the $\mathrm{Cd} / \mathrm{Ca}$ value at $32 \mathrm{~cm}$, significantly exceeds this upper bound. The simplest interpretation of the records is therefore in terms of constant seawater trace metal concentrations and changing $\Delta \mathrm{CO}_{3}{ }^{2-}$.

$\triangle \mathrm{CO}_{3}{ }^{2-}$ values inferred from $\mathrm{C}$. wuellerstorfi

Let us assume that dissolved $\mathrm{Zn}$ and $\mathrm{Cd}$ concentrations in the waters overlying ODP Site 849 have not changed significantly over the past glacial-interglacial cycle. Then benthic foraminiferal $\mathrm{Zn} / \mathrm{Ca}$ and $\mathrm{Cd} / \mathrm{Ca}$ can be converted into inferred partition coefficients by dividing by modern seawater $\mathrm{Zn} / \mathrm{Ca}$ and $\mathrm{Cd} / \mathrm{Ca}$ ratios. Partition coefficients can further be converted into $\Delta \mathrm{CO}_{3}{ }^{2-}$ according to the relationships defined in Chapter 2:

$$
\begin{aligned}
\Delta \mathrm{CO}_{3}{ }^{2-} & =\left(D_{\mathrm{Zn}}-5.25\right) / 0.15 \\
\Delta \mathrm{CO}_{3}{ }^{2-} & =\left(D_{\mathrm{Cd}}-2.5\right) / 0.1
\end{aligned}
$$

The results of this transformation are shown in Figure 3.11. $\mathrm{Zn} / \mathrm{Ca}$-derived $\Delta \mathrm{CO}_{3}{ }^{2-}$ values close to $25 \mu \mathrm{mol} \mathrm{mol}{ }^{-1}$ correspond to $D_{\mathrm{Zn}} \approx 9$, and therefore actually represent values $\geq 25$ $\mu \mathrm{mol} \mathrm{mol}{ }^{-1}$. Similarly, $\mathrm{Cd} / \mathrm{Ca}$-derived $\Delta \mathrm{CO}_{3}{ }^{2-}$ values close to $5 \mu \mathrm{mol} \mathrm{kg}{ }^{-1}$ correspond to $D_{\mathrm{Cd}} \approx 3$ and $\Delta \mathrm{CO}_{3}{ }^{2-} \geq 5 \mu \mathrm{mol} \mathrm{kg}{ }^{-1}$. It is promising that all but one of the data appear to 
stop at these two limits. In other words, the existence of numerous inferred $D_{\mathrm{Cd}}$ values very close to 3 , but only one value significantly greater than 3 , implies that the assumption of constant seawater $\mathrm{Cd}$ concentration may be reasonable.

The highest $\Delta \mathrm{CO}_{3}{ }^{2-}$ values in each record occur during Termination I. Both $\mathrm{Cd} / \mathrm{Ca}$ and $\mathrm{Zn} / \mathrm{Ca}$ reach the limits of their sensitivities, yielding increases of $\geq 9$ and $\geq 29 \mu \mathrm{mol}$ $\mathrm{kg}^{-1}$, respectively, relative to today. The onset of the $\Delta \mathrm{CO}_{3}{ }^{2-}$ peak appears to precede benthic $\delta^{18} \mathrm{O}$ and $\delta^{13} \mathrm{C}$ changes by several thousand years, and the subsequent decrease begins during the early to middle Holocene. LGM inferred $\Delta \mathrm{CO}_{3}{ }^{2-}$ values (prior to the rise

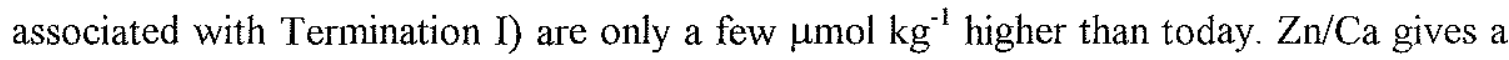
mean difference of $6 \pm 1 \mu \mathrm{mol} \mathrm{kg} \mathrm{kg}^{-1}$, and $\mathrm{Cd} / \mathrm{Ca}$ suggests $2 \pm 3 \mu \mathrm{mol} \mathrm{kg}{ }^{-1}$. The most undersaturated $\Delta \mathrm{CO}_{3}{ }^{2-}$ values in the record occur during MIS 4 , with inferred values $\sim 3$ to $4 \mu \mathrm{mol} \mathrm{kg}{ }^{-1}$ lower than today. Although $\mathrm{Zn} / \mathrm{Ca}$-based and $\mathrm{Cd} / \mathrm{Ca}$-based estimates compare favorably over much of the record, there is substantial disagreement during much of MIS 3.

$\Delta \mathrm{CO}_{3}{ }^{2-}$ values can be converted to $\left[\mathrm{CO}_{3}{ }^{2-}\right]_{\text {in situ }}$ by calculating $\left[\mathrm{CO}_{3}{ }^{2-}\right]_{\text {saturation, }}$ which is a function of pressure, temperature, and salinity. During the LGM, sea level was $\sim 120 \mathrm{~m}$ lower than today, salinity was $\sim 1 \%$ higher, and mean ocean $\delta^{18} \mathrm{O}$ was $\sim 1.0 \%$ to $1.3 \%$ o higher (Fairbanks, 1989; Schrag et al., 1996). Subtracting the $\delta^{18} \mathrm{O}$ shift from the ODP 849 benthic record (including new data in Table 3.2) suggests that LGM bottom waters were $\sim 0^{\circ}$ to $2^{\circ} \mathrm{C}$ colder than today (Epstein et al., 1953). Assuming no cooling, the net result of pressure and salinity changes would be an LGM drop in $\left[\mathrm{CO}_{3}{ }^{2-}\right]_{\text {saturation }}$ of $\sim 2 \mu \mathrm{mol}$ $\mathrm{kg}^{-1}$, meaning that a $\Delta \mathrm{CO}_{3}{ }^{2-}$ change of $+6 \mu \mathrm{mol} \mathrm{kg}{ }^{-1}$ would correspond to a $\left[\mathrm{CO}_{3}{ }^{2-}\right]_{\text {in situ }}$ change of $+4 \mu \mathrm{mol} \mathrm{kg}{ }^{-1}$. A $2^{\circ} \mathrm{C}$ cooling would result in no net change in $\left[\mathrm{CO}_{3}{ }^{2-}\right]_{\text {saturation. It }}$ is therefore reasonable to assume that $\left[\mathrm{CO}_{3}{ }^{2-}\right]_{\text {in situ }}$ shifts have remained within about -2 $\mu \mathrm{mol} \mathrm{kg}{ }^{-1}$ of $\Delta \mathrm{CO}_{3}{ }^{2-}$ shifts. Estimated $\Delta \mathrm{CO}_{3}{ }^{2-}$ and $\left[\mathrm{CO}_{3}{ }^{2-}\right]_{\text {in situ }}$ values for Termination $\mathrm{I}$, the LGM, and MIS 4 are listed in Table 3.3.

The very high $\Delta \mathrm{CO}_{3}{ }^{2-}$ values observed during the deglaciation $\left(\geq 29 \mu \mathrm{mol} \mathrm{kg}{ }^{-1}\right.$ higher than today) should be accompanied by a $\mathrm{CaCO}_{3}$ preservation spike, with 
dissolution increasing through the late Holocene. Berger (1977) summarized evidence for a "global" deglacial pteropod and foraminifera preservation spike centered around 11,000 yr BP (Berger and Keir, 1984). Of course, such deglacial events could have been caused by increased $\mathrm{CaCO}_{3}$ production rather than reduced seafloor dissolution (e.g., Keigwin et al., 1992). However, Keir and Berger (1985), Broecker et al. (1991), and others have suggested that anomalously old ${ }^{14} \mathrm{C}$ ages accompanied by reduced $\mathrm{CaCO}_{3}$ percentages in deep tropical Pacific core tops are indeed indicative of increased dissolution over the past few thousand years. Reduced ${ }^{230} \mathrm{Th}$-normalized $\mathrm{CaCO}_{3}$ accumulation rates over the same interval support this hypothesis (Berelson et al., 1997). Berelson et al. (1997) further argued that the dissolution increase was not due to higher $\mathrm{C}_{\text {org }}: \mathrm{CaCO}_{3}$ rain ratios, but to a decrease in deep water $\mathrm{CO}_{3}{ }^{2-}$ concentration of $\sim 10$ to $15 \mu \mathrm{mol} \mathrm{kg}{ }^{-1}$ over the past 3000 years.

Another useful way to infer dissolution is through fragmentation of planktonic foraminifera. Fragmentation indices have been generated for nearby ODP Sites 846 $\left(3^{\circ} 6^{\prime} \mathrm{S}, 90^{\circ} 49^{\prime} \mathrm{W}, 3307 \mathrm{~m}\right.$; Le et al., 1995) and $847\left(0^{\circ} 12^{\prime} \mathrm{N}, 9^{\circ} 19^{\prime} \mathrm{W}, 3334 \mathrm{~m}\right.$; McKenna et al., 1995) (Figure 3.12). Both show a preservation spike centered on Termination I and commencing well before the end of MIS 2, consistent with my inferred $\Delta \mathrm{CO}_{3}{ }^{2-}$ records. Fragmentation in the upper $72 \mathrm{~cm}$ of ODP 849 (this study) also follows this pattern, with timing closely coupled to $\Delta \mathrm{CO}_{3}{ }^{2-}$ (Figure 3.13). Recently, Broecker and Clark (in press) showed that another fragmentation index, the percentage of $\mathrm{CaCO}_{3}>63$ $\mu \mathrm{m}$, is linearly related to $\Delta \mathrm{CO}_{3}{ }^{2-}$ in the modern ocean. Broecker et al. (in press) measured this index in several deep Atlantic cores and in one deep western Pacific core and estimated that global ocean $\mathrm{CO}_{3}{ }^{2-}$ concentrations were $11 \pm 2 \mu \mathrm{mol} \mathrm{kg}{ }^{-1}$ higher than today around 7000 to $10,000 \mathrm{yr}$ BP (radiocarbon ages). This peak, which Broecker et al. (in press) attributed to a $\mathrm{CaCO}_{3}$ compensation response to forest regrowth, may occur too late to correlate with the deglacial $\Delta \mathrm{CO}_{3}{ }^{2-}$ peak seen in ODP 849 . However, in their Pacific core, the peak actually appears to begin around $14,000 \mathrm{yr}$ BP and reaches nearmaximum values by $\sim 12,000 \mathrm{yr} \mathrm{BP}$. 
It has long been recognized (Arrhenius, 1952) that deep Pacific sediments generally contain more $\mathrm{CaCO}_{3}$ during the $\mathrm{LGM}$, and during glacial intervals in general, than during interglacials. Correlations between $\% \mathrm{CaCO}_{3}$ and fragmentation indices indicate that these fluctuations most often represent changes in dissolution (e.g., Berger, 1968). Farrell and Prell (1989) used $\% \mathrm{CaCO}_{3}$ to estimate that the sedimentary lysocline in the central equatorial Pacific was $\sim 800$ m deeper during the LGM than today. Assuming that the sedimentary lysocline remained coupled to the hydrographic saturation horizon, this implies an LGM increase in $\Delta \mathrm{CO}_{3}{ }^{2-}$ of $\sim 5 \mu \mathrm{mol} \mathrm{kg}{ }^{-1}$. This estimate is indistinguishable from those derived from $\mathrm{Zn} / \mathrm{Ca}$ and $\mathrm{Cd} / \mathrm{Ca}$ in ODP 849 .

Finally, there is sedimentary evidence for severe dissolution in the deep Pacific during MIS 4 , the interval in ODP 849 with the lowest inferred $\Delta \mathrm{CO}_{3}{ }^{2-}$ values. Passlow (1997) used ostracod and planktonic foraminiferal dissolution indices to show that MIS 4 was by far the most poorly preserved interval of a 140,000 yr record from $2346 \mathrm{~m}$ depth off southeastern Australia. Hiramatsu and De Deckker (1997) measured calcareous nannoplankton dissolution (\% perfect Calcidiscus leptoporus) in a core from the same region $(2667 \mathrm{~m}$ ), and found that preservation at the MIS 5/4 boundary was the worst since the MIS 7/6 boundary. At ODP 847 (McKenna et al., 1995) planktonic foraminiferal fragmentation was high at the 5/4 transition, but at nearby ODP 846 (Le et al., 1995) there is, if anything, a slight decrease in fragmentation (Figure 3.12). In the Indian Ocean, composite dissolution indices show that the strongest dissolution pulse of the past 250,000 years occurred on the MIS 5/4 boundary (Peterson and Prell, 1985).

It should be noted here that the differences in fragmentation histories among various Pacific sites must be due, in large part, to factors other than bottom water $\Delta \mathrm{CO}_{3}{ }^{2-}$. As noted above, pore water (respiratory) $\mathrm{CO}_{2}$, which is related to organic matter flux to the sediment, may partially decouple dissolution from bottom water saturation state. Fragmentation can also change in response to planktonic foraminiferal assemblage changes (e.g., Berger, 1968) or to the $\mathrm{Mg}$ content of foraminiferal calcite, which is known to vary with calcification temperature (Lorens et al., 1977; Cronblad and Malmgren, 1981; Brown 
and Elderfield, 1996). These issues can be avoided by using benthic foraminiferal $\mathrm{Zn} / \mathrm{Ca}$ and $\mathrm{Cd} / \mathrm{Ca}$, which appear to respond directly to bottom water conditions.

\section{Implications for modeling atmospheric $\mathrm{CO}_{2}$}

The overall picture that emerges from ODP 849 , with the support of published data, is similar to the predictions of $\mathrm{CaCO}_{3}$ compensation models that transfer $\Sigma \mathrm{CO}_{2}$ to the deep ocean (Broecker and Peng, 1987; Boyle, 1988b) (Figure 3.1). The two most striking features are $\mathrm{CO}_{3}{ }^{2-}$ minimum on the MIS $5 / 4$ boundary and a $\mathrm{CO}_{3}{ }^{2-}$ maximum on Termination I, with LGM values being only slightly higher than today. This pattern contrasts strongly with the pore water dissolution model of Archer and Maier-Reimer (1994) and the $\delta^{11} \mathrm{~B}$ data of Sanyal et al. (1995), which predict LGM CO${ }_{3}{ }^{2-}$ concentrations $\sim 50$ to $100 \mu \mathrm{mol} \mathrm{kg}{ }^{-1}$ higher than today (Figure 3.1). Boyle's (1988b) model (which will here be taken as representative of a class of $\mathrm{CaCO}_{3}$ compensation models) calls for a transfer of $\Sigma \mathrm{CO}_{2}$ from the intermediate ocean to the deep ocean at the end of interglacial MIS 5. This could be accomplished through several mechanisms (Boyle, 1988b), including: the formation of Glacial North Atlantic Intermediate Water (GNAIW) at the expense of North Atlantic Deep Water (NADW) (e.g., Boyle and Keigwin, 1987); "nutrient leakage" due to increased low-latitude upwelling (Boyle, 1986); and/or enhanced primary productivity in the source regions of intermediate waters (e.g., Martin and Fitzwater, 1988). Deep ocean $\left[\mathrm{CO}_{3}{ }^{2-}\right]$ drops initially and is then restored through $\mathrm{CaCO}_{3}$ compensation. The various $\Sigma \mathrm{CO}_{2}$-transfer mechanisms cease at the end of glacial MIS 2 , restoring $\mathrm{\Sigma CO}_{2}$ to the intermediate ocean and leaving the deep ocean temporarily enriched in $\mathrm{CO}_{3}{ }^{2-}$.

Due to the response time of $\mathrm{CaCO}_{3}$ compensation (Broecker and Peng, 1987), Boyle's (1988b) model requires that transfers of $\Sigma \mathrm{CO}_{2}$ between the intermediate and deep ocean precede full atmospheric $\mathrm{CO}_{2}$ changes by several thousand years. Since atmospheric $\mathrm{CO}_{2}$ changes appear to precede ice volume (Shackleton and Pisias, 1985; Broecker and Henderson, 1998), Boyle's (1988b) transfers must also precede ice volume by at least 
several thousand years. The signatures of these transfers, namely inferred deep ocean $\left[\mathrm{CO}_{3}^{2-}\right]$ (Figure 3.14) and planktonic-benthic foraminiferal $\delta^{13} \mathrm{C}$ differences (e.g., Shackleton and Pisias, 1985), indeed lead benthic $\delta^{18} \mathrm{O}$ significantly at Termination I. The expected $\left[\mathrm{CO}_{3}{ }^{2-}\right]$ lead at the MIS 5/4 boundary is not apparent (Figure 3.14).

Although the observations are generally consistent with Boyle's (1988b) hypothesis, it is unclear whether or not the model can explain more than a small fraction of the LGM-Holocene atmospheric $\mathrm{CO}_{2}$ difference. Using a five-box ocean model, Boyle (1988b) estimated that up to 46 ppmv of the 90 ppmv drop could be accounted for by altering the vertical regeneration of organic matter such that more remineralization occurred in the deep ocean (cases G1, G2). Another, perhaps more realistic, mechanism for exporting $\Sigma \mathrm{CO}_{2}$ to the deep ocean is by increasing low-latitude wind-driven upwelling, resulting in a transient productivity increase and a "nutrient leakage". This would account for only $\sim 13$ to 27 ppmv of the drop, depending on how much $\mathrm{CaCO}_{3}$ was remineralized along with the organic matter (cases G3, G4). Changing NADW into GNAIW would only have an impact of $\sim 8$ ppmv (case G5). Emerson and Archer (1992) used a more detailed model to estimate that a vertical redistribution of $\mathrm{CO}_{2}$ similar to cases $\mathrm{G} 1$ and $\mathrm{G} 2$ (transferring $\Sigma \mathrm{CO}_{2}$ only) could account for only $\sim 9$ to $15 \mathrm{ppmv}$ of the change, while a scenario similar to cases $\mathrm{G} 3$ and $\mathrm{G} 4$ (transferring $\Sigma \mathrm{CO}_{2}$ and alkalinity together) reduced atmospheric $\mathrm{CO}_{2}$ by only $\sim 3$ to 4 ppmv.

One difference between the studies of Boyle (1988b) and Emerson and Archer (1992) is the magnitude of the $\Sigma \mathrm{CO}_{2}$ vertical redistributions (which are not well constrained by paleonutrient data) and the resulting transient $\left[\mathrm{CO}_{3}{ }^{2-}\right]$ shifts. Data available to Boyle (1988b) may have overestimated the glacial Pacific vertical nutrient gradient (Boyle, 1992), though the $\delta^{13} \mathrm{C}$ data of Herguera et al. (1992) and Keigwin (1998) imply a significant nutricline near $2000 \mathrm{~m}$ depth. Also, it is possible that glacial $\Sigma \mathrm{CO}_{2}$ and $\delta^{13} \mathrm{C}$ vertical gradients exceeded those of nutrients such as Cd because of changes in ocean ventilation (Toggweiler, 1999). Boyle (1988b) (in his extreme case G1) predicted a Termination $\mathrm{I}\left[\mathrm{CO}_{3}{ }^{2-}\right]$ peak of $\sim 30 \mu \mathrm{mol} \mathrm{kg}{ }^{-1}$ relative to today, while Emerson and 
Archer's (1992) model results in a peak of no more than $\sim 10$ to $15 \mu \mathrm{mol} \mathrm{kg}{ }^{-1} . \mathrm{Zn} / \mathrm{Ca}$ results from ODP 849 suggest that the larger estimate may be more accurate. Table 3.4 shows how modeling of the ODP 849 data can yield estimates of deep ocean alkalinity, $\Sigma \mathrm{CO}_{2}$, and $\mathrm{pH}$ for the LGM.

In any case, it is likely that several mechanisms combined to produce the total atmospheric $\mathrm{CO}_{2}$ drop. For example, if some additional $\mathrm{CO}_{2}$ were transferred directly from the atmosphere into the deep ocean through increased productivity, then the "biological pump" and $\mathrm{CaCO}_{3}$ compensation could be working together (Broecker and Peng, 1987). This combination would be maximized by increasing high-latitude production (e.g., by iron fertilization [Martin and Fitzwater, 1988]) because the problem of adding alkalinity to the deep ocean along with $\mathrm{SCO}_{2}$ would be minimized by the dominance of siliceous organisms (Keir, 1988). At lower latitudes, increased $\mathrm{CaCO}_{3}$ productivity would have to be offset by increased $\mathrm{C}_{\text {org }}: \mathrm{CaCO}_{3}$ rain ratios. Sigman et al. (1998) calculated that a $50 \%$ rise in low to mid-latitude production (caused by an addition of phosphate) coupled with a doubling of the rain ratio of that production (and assuming no respiratory dissolution response) could account for the entire LGM atmospheric $\mathrm{CO}_{2}$ drop without significantly displacing the calcite saturation horizon.

\section{Possible constraints on oceanic $\mathrm{Zn}$ and $\mathrm{Cd}$ inventories}

As noted above, there is substantial disagreement between $\mathrm{Zn} / \mathrm{Ca}$-based and $\mathrm{Cd} / \mathrm{Ca}$-based $\Delta \mathrm{CO}_{3}{ }^{2-}$ estimates during some intervals of the ODP 849 record, particularly during MIS 3 (Figure 3.11). There are several possible reasons for discrepancies. First, although the $D_{\mathrm{Zn}}: \Delta \mathrm{CO}_{3}{ }^{2-}$ relationship is reasonably well defined, the $D_{\mathrm{Cd}}: \Delta \mathrm{CO}_{3}{ }^{2-}$ relationship remains poorly defined. This uncertainty might account for some of the apparent inconsistency, but the issue cannot be resolved until more high-quality late Holocene data are added to the core top calibration. The $\mathrm{Zn} / \mathrm{Ca}$ and $\mathrm{Cd} / \mathrm{Ca}$-based estimates would be in reasonably good agreement if a $D_{\mathrm{Cd}}$ of 2 were to correspond to a $\Delta \mathrm{CO}_{3}{ }^{2-}$ value of $\sim 0 \mu \mathrm{mol} \mathrm{kg}{ }^{-1}$ (rather than the value of $-5 \mu \mathrm{mol} \mathrm{kg}{ }^{-1}$ predicted in Chapter 
2). Second, authigenic and laboratory contaminations are always potential problems, but I will assume that they are not major factors here. Third, changes in deep ocean circulation can cause seawater dissolved $\mathrm{Zn}$ and $\mathrm{Cd}$ concentrations to diverge from their modern deep eastern equatorial Pacific ratio, but only very slightly. Finally, changes in the oceanic dissolved inventories of $\mathrm{Zn}$ and/or $\mathrm{Cd}$ can cause large apparent discrepancies. If the first three factors are assumed to be negligible, the magnitudes of inventory changes required to explain the diverging $\mathrm{Zn} / \mathrm{Ca}$ and $\mathrm{Cd} / \mathrm{Ca}$ data can be evaluated. Given all of the uncertainties involved, this should be taken as no more than a crude sensitivity test. Better estimates of inventory changes will require many additional records from Pacific sites with a wide range of modern $\Delta \mathrm{CO}_{3}{ }^{2-}$ values.

Most of the disagreement between $\mathrm{Zn} / \mathrm{Ca}$ and $\mathrm{Cd} / \mathrm{Ca}$ could be explained if MIS 3 seawater $\mathrm{Cd}$ concentrations were $\sim 25 \%$ lower than today (Figure $3.15 \mathrm{a}$ ). This adjustment causes many of the data in question to overlap. Also recall that $\Delta \mathrm{CO}_{3}{ }^{2-}$ values inferred

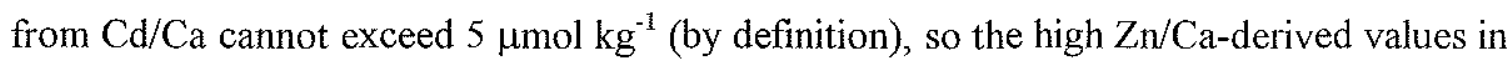
early MIS 3 need not be matched by $\mathrm{Cd} / \mathrm{Ca}$. A $25 \%$ decrease in dissolved $\mathrm{Cd}$ inventory is of a similar order to Boyle's (1992) LGM global estimate of a $13 \%$ decrease. It is also close to the LGM Uvigerina $\mathrm{Cd} / \mathrm{Ca}$ decrease of $\sim 15-20 \%$ observed in core TR163-31B from the deep eastern tropical Pacific (Boyle, 1988), a record that is not expected to have been influenced by saturation effects (modern $\Delta \mathrm{CO}_{3}{ }^{2-} \approx 6 \mu \mathrm{mol} \mathrm{kg}^{-1}$ ). Alternatively, much of the disagreement between $\mathrm{Zn} / \mathrm{Ca}$ and $\mathrm{Cd} / \mathrm{Ca}$ could be explained if MIS 3 seawater $\mathrm{Zn}$ concentrations were $\sim 25 \%$ higher than today (Figure 3.15b). This exercise keeps both $\mathrm{Cd} / \mathrm{Ca}$ and $\mathrm{Zn} / \mathrm{Ca}$ below their limits of sensitivity, so some offset remains during early MIS 3. If the error in Boyle's (1992) estimate of the glacial Cd inventory is no larger than the estimate itself (i.e., $-13 \% \pm 13 \%$ ), then the present analysis suggests that the glacial $\mathrm{Zn}$ inventory was probably within about $+25 \%$ of the modern. The magnitudes of these possible shifts, if unaccounted for, would result in $\Delta \mathrm{CO}_{3}{ }^{2-}$ errors on the order of 5 to 10 $\mu \mathrm{mol} \mathrm{kg}{ }^{-1}$. 


\section{$\mathrm{Zn} / \mathrm{Ca}$ and $\mathrm{Cd} / \mathrm{Ca}$ in $\mathrm{N}$. umbonifera and Uvigerina}

$\mathrm{Zn} / \mathrm{Ca}$ and $\mathrm{Cd} / \mathrm{Ca}$ data from $N$. umbonifera are generally close to $C$. wuellerstorfi values, but appear to show slightly less variation (Figure 3.8). In Chapter 2 it was noted that no relationships have been identified between $N$. umbonifera partition coefficients and $\Delta \mathrm{CO}_{3}{ }^{2-}$. If these partition coefficients are in fact constant, then $N$. umbonifera data can be converted directly into seawater dissolved $\mathrm{Zn}$ and $\mathrm{Cd}$ estimates. Figure 3.16a shows the results of this transformation, using a $D_{\mathrm{Zn}}$ of 5 and a $D_{\mathrm{Cd}}$ of 2.5 (slightly higher than the rough estimates in Chapter 2). The two tracers show similar patterns of variability, with values during the Holocene/Termination I and MIS 5 generally higher than glacial values. However, when scaled to each other in terms of circulation (i.e., using the $\mathrm{Zn}: \mathrm{Cd}$ proportionality observed in the modern Pacific), inferred $\mathrm{Cd}_{W}$ displays a significantly larger range than $Z n_{W}$. Also, both tracers appear to greatly exceed the range of circulation-induced change predicted from $\delta^{13} \mathrm{C}$. These observations imply that the data cannot be explained by circulation changes alone. It is possible that the inferred $\mathrm{Zn}_{\mathrm{W}}$ and $\mathrm{Cd}_{\mathrm{W}}$ concentrations could have resulted from a combination of circulation and oceanic inventory changes. Alternatively, a portion of the $N$. umbonifera $\mathrm{Zn} / \mathrm{Ca}$ and $\mathrm{Cd} / \mathrm{Ca}$ variability could be due to a yet-unidentified relationship between partition coefficients and $\Delta \mathrm{CO}_{3}{ }^{2-}$ in this species. Because of the uncertainty surrounding $N$. umbonifera partition coefficients, combined with the sparsity of the data, no correction for possible seawater trace metal changes will be made to the $C$. wuellerstorfi record. The maximum magnitude of such corrections (interglacial) would be on the order of $10 \mu \mathrm{mol} \mathrm{kg}{ }^{-1}$.

The $\mathrm{Zn} / \mathrm{Ca}$ and $\mathrm{Cd} / \mathrm{Ca}$ data from Uvigerina spp. are not easily explained. This genus shows a similar magnitude of variability to C. wuellerstorfi and $N$. umbonifera, but very little correspondence (Figure 3.8). Relative to the other two taxa, Uvigerina $\mathrm{Zn} / \mathrm{Ca}$ values are often much lower, while $\mathrm{Cd} / \mathrm{Ca}$ values range from similar to much higher. One possible explanation is that the apparent relationships between Uvigerina partition coefficients and $\Delta \mathrm{CO}_{3}{ }^{2-}$ (Chapter 2 ) have been incorrectly characterized. In particular, 
there are no Uvigerina core top $\mathrm{Zn} / \mathrm{Ca}$ data from waters in the $\Delta \mathrm{CO}_{3}{ }^{2-}$ range of $\sim 0$ to 35 $\mu \mathrm{mol} \mathrm{kg}^{-1}$. In ODP 849 , limited agreement with $N$. umbonifera can be achieved by choosing constant Uvigerina partition coefficients of $D_{\mathrm{Zn}}=4$ and $D_{\mathrm{Cd}}=2.5$, but significant scatter remains (Figure 3.16b). It is possible that the shallow infaunal habitat of Uvigerina makes it a poor recorder of bottom water $\Delta \mathrm{CO}_{3}{ }^{2-}$ values, as is the case for $\delta^{13} \mathrm{C}$ ( $\mathrm{Zahn}$ et al., 1986; Keigwin et al., 1992).

\section{Conclusions}

$\mathrm{Zn} / \mathrm{Ca}$ and $\mathrm{Cd} / \mathrm{Ca}$ variability in C. wuellerstorfi from ODP 849 is best explained in terms of bottom water saturation state with respect to calcite. The data suggest a low$\left[\mathrm{CO}_{3}{ }^{2-}\right]$ excursion at the beginning of MIS 4 and a dramatic high- $\left[\mathrm{CO}_{3}{ }^{2-}\right]$ excursion associated with Termination I. Inferred LGM concentrations were only a few $\mu$ mol $\mathrm{kg}^{-1}$ higher than today, in contrast to the $\delta^{11} \mathrm{~B}$-based estimates of Sanyal et al. (1995). These observations are consistent with transfers of $\mathrm{\Sigma CO}_{2}$ into and out of the deep ocean at glacial-interglacial boundaries (Broecker and Peng, 1987; Boyle, 1988b). Measurement of benthic foraminiferal $\mathrm{Zn} / \mathrm{Ca}$ and $\mathrm{Cd} / \mathrm{Ca}$ at other deep Pacific sites may help to constrain the magnitude of atmospheric $\mathrm{CO}_{2}$ changes that could have resulted from this mechanism. The largest uncertainties in the present study surround the oceanic dissolved inventories of $\mathrm{Zn}$ and $\mathrm{Cd}$. Better constraints on the time evolution of these quantities, in theory derivable from synoptic $\mathrm{Zn} / \mathrm{Ca}$ and $\mathrm{Cd} / \mathrm{Ca}$ reconstructions, are required for estimating paleo- $\left[\mathrm{CO}_{3}{ }^{2-}\right]$ with greater certainty. 


\section{References}

Adkins, J. F., E. A. Boyle, L. Keigwin, and E. Cortijo, Variability of the North Atlantic thermohaline circulation during the last interglacial period, Nature, 390, 154-156, 1997.

Archer, D., and E. Maier-Reimer, Effect of deep-sea sedimentary calcite preservation on atmospheric $\mathrm{CO}_{2}$ concentration, Nature, 367, 260-263, 1994.

Archer, D., S. Emerson, and C. E. Reimers, Dissolution of calcite in deep-sea sediments: $\mathrm{pH}$ and $\mathrm{O}_{2}$ microelectrode results, Geochim. Cosmochim. Acta, 53, 2831-2846, 1989.

Arrhenius, G. O. S., Sediment cores from the east Pacific, Rep. Swed. Deep Sea Exped. $1947-1948,5,1-228,1952$.

Barnola, J. M., D. Raynaud, Y. S. Korotkevich, and C. Lorius, Vostok ice core provides 160,000-year record of atmospheric $\mathrm{CO}_{2}$, Nature, 329, 408-414, 1987.

Berelson, W. M., et al., Biogenic budgets of particle rain, benthic remineralization and sediment accumulation in the equatorial Pacific, Deep-Sea Res. II, 44, 2251-2282, 1997.

Berger, W. H., Planktonic foraminifera: selective solution and paleoclimatic interpretation, Deep-Sea Res., 15, 31-43, 1968.

Berger, W. H., Deep-sea carbonate and the deglaciation preservation spike in pteropods and foraminifera, Nature, 269, 301-304, 1977.

Berger, W. H., and R. S. Keir, Glacial-Holocene changes in atmospheric $\mathrm{CO}_{2}$ and the deep-sea record, in Climate Processes and Climate Sensitivity, Geophys. Monogr. Ser., Vol. 29, edited by J. Hansen and T. Takahashi, pp. 337-351, AGU, Washington, 1984.

Boyle, E. A., Manganese carbonate overgrowths of foraminifera tests, Geochim. et Cosmochim. Acta, 47, 1815-1819, 1983.

Boyle, E. A., Deep ocean circulation, preformed nutrients, and atmospheric carbon dioxide: theories and evidence from oceanic sediments, in Mesozoic and Cenozoic Oceans, edited by K. J. Hsu, pp. 49-59, AGU Geodynamics Series Vol. 15, Washington, 1986.

Boyle, E. A., Cadmium: Chemical tracer of deepwater paleoceanography, Paleoceanography, 3, 471-489, 1988a. 
Boyle, E. A., The role of vertical chemical fractionation in controlling Late Quaternary atmospheric carbon dioxide, J. Geophys. Res., 93, 15701-15714, 1988b.

Boyle, E. A., Cadmium and $\delta^{13} \mathrm{C}$ paleochemical ocean distributions during the Stage 2 glacial maximum, Anmu. Rev. Earth Planet. Sci., 20, 245-287, 1992.

Boyle, E. A., and L. D. Keigwin, Comparison of Atlantic and Pacific paleochemical records for the last 215,000 years: changes in deep ocean circulation and chemical inventories, Earth Planet. Sci. Lett., 76, 135-150, 1985/86.

Boyle, E. A., and L. D. Keigwin, North Atlantic thermohaline circulation during the last 20,000 years linked to high latitude surface temperature, Nature, 330, 35-40, 1987.

Boyle, E. A., and Y. Rosenthal, Chemical hydrography of the South Atlantic during the last glacial maximum: $\mathrm{Cd}$ vs. $\delta^{13} \mathrm{C}$, in The South Atlantic: Present and Past Circulation, edited by G. Wefer et al., pp. 423-443, Springer-Verlag, Berlin, 1996.

Boyle, E. A., F. R. Sclater, and J. M. Edmond, On the marine geochemistry of cadmium, Nature, 263, 42-44, 1976.

Broecker, W. S., The Glacial World According to Wally, Eldigio Press, Palisades, 1995.

Broecker, W. S., and E. Clark, $\mathrm{CaCO}_{3}$ size distribution: A paleo carbonate ion proxy?, Paleoceanography, in press.

Broecker, W. S., and G. M. Henderson, The sequence of events surrounding Termination II and their implications for the cause of glacial-interglacial $\mathrm{CO}_{2}$ changes, Paleoceanography, 13, 352-364, 1998.

Broecker, W. S., and E. Maier-Reimer, The influence of air and sea exchange on the carbon isotope distribution in the sea, Global Biogeochem. Cycles, 6, 315-320, 1992.

Broecker, W. S., and T.-H. Peng, The role of $\mathrm{CaCO}_{3}$ compensation in the glacial to interglacial atmospheric $\mathrm{CO}_{2}$ change, Global Biogeochem. Cycles, 1, 15-29, 1987.

Broecker, W. S., D. W. Spencer, and H. Craig, GEOSECS Pacific Expedition, Vol. 3, Hydrographic Data, U. S. Government Printing Office, Washington, 1982.

Broecker, W. S., M. Klas, E. Clark, G. Bonani, S. Ivy, and W. Wolfi, The influence of $\mathrm{CaCO}_{3}$ dissolution on core top radiocarbon ages for deep-sea sediments, Paleoceanography, 6, 593-608, 1991. 
Broecker, W. S., E. Clark, D. C. McCorkle, T.-H. Peng, I. Hajdas, and G. Bonani, Evidence for a reduction in the carbonate ion content of the deep sea during the course of the Holocene, Paleoceanography, in press.

Brown, S. J., and H. Elderfield, Variations in $\mathrm{Mg} / \mathrm{Ca}$ and $\mathrm{Sr} / \mathrm{Ca}$ ratios of planktonic foraminifera caused by postdepositional dissolution: Evidence of shallow Mgdependent dissolution, Paleoceanography, 11, 543-551, 1996.

Bruland, K. W., G. A. Knauer, and J. H. Martin, Zinc in north-east Pacific water, Nature, 271, 741-743, 1978.

Collier, R., and J. Edmond, The trace element geochemistry of marine biogenic particulate matter, Prog. Oceanogr., 13, 113-199, 1984.

Cronblad, H. G., and B. A. Malmgren, Climatically controlled variation of strontium and magnesium in Quaternary planktonic foraminifera, Nature, 291, 61-64, 1981.

Delmas, R. J., J. M. Ascencio, and M. Legrand, Polar ice evidence that atmospheric $\mathrm{CO}_{2}$ 20,000 yr BP was $50 \%$ of present, Nature, 284, 155-157, 1980.

Duce, R. A., et al., The atmospheric input of trace species to the world ocean, Global Biogeochem. Cycles, 5, 193-259, 1991.

Duplessy, J.-C., N. J. Shackleton, R. K. Matthews, W. L. Prell, W. F. Ruddiman, M. Caralp, and C. H. Hendy, ${ }^{13} \mathrm{C}$ record of benthic foraminifera in the last interglacial ocean: implications for the carbon cycle and the global deep water circulation, Quat. Res., 21, 225-243, 1984.

Duplessy, J.-C., N. J. Shackleton, R. G. Fairbanks, L. Labeyrie, D. Oppo, and N. Kallel, Deepwater source variations during the last climatic cycle and their impact on the global deepwater circulation, Paleoceanography, 3, 343-360, 1988.

Edmond, J. M., et al., Time series studies of vent fluids from the TAG and MARK sites (1986, 1990) Mid-Atlantic Ridge: a new solution chemistry model and a mechanism for $\mathrm{Cu} / \mathrm{Zn}$ zonation in massive sulphide orebodies, in Hydrothermal Vents and Processes, edited by L. M. Parson et al., pp. 77-86, Geological Society Special Publication No. 87, 1995.

Emerson, S., and D. Archer, Glacial carbonate dissolution cycles and atmospheric $\mathrm{pCO}_{2}$ : A view from the ocean bottom, Paleoceanography, 7, 319-331, 1992. 
Emerson, S., and M. L. Bender, Carbon fluxes at the sediment water interface of the deep sea: Calcium carbonate preservation, J. Mar. Res., 39, 139-162, 1981.

Epstein, S. R., R. Buchsbaum, H. A. Lowenstam, and H. C. Urey, Revised carbonatewater isotopic temperature scale, Geol. Soc. Am. Bull., 64, 1315-1325, 1953.

Fairbanks, R. G., A 17,000-year glacio-eustatic sea level record: influence of glacial melting rates on the Younger Dryas event and deep-ocean circulation, Nature, 342, 637-642, 1989.

Farrell, J. W., and W. L. Prell, Climate change and $\mathrm{CaCO}_{3}$ preservation: An 800,000 year bathymetric reconstruction from the central equatorial Pacific Ocean, Paleoceanography, 4, 447-466, 1989.

Feely, R. A., G. J. Massoth, J. H. Trefry, E. T. Baker, A. J. Paulson, and G. T. Lebon, Composition and sedimentation of hydrothermal plume particles from North Cleft segment, Juan de Fuca Ridge, J. Geophys. Res., 99, 4985-5006, 1994.

Hagelberg, T. K., N. G. Pisias, N. J. Shackleton, A. C. Mix, and S. Harris, Refinement of a high-resolution, continuous sedimentary section for studying equatorial Pacific Ocean paleoceanography, Leg 138, in Proc. of the Ocean Drilling Program, Sci. Results, 138, edited by N. G. Pisias et al., pp. 31-46, NSF, Washington, 1995.

Hales, B., and S. Emerson, Calcite dissolution in sediments of the Ceara Rise: In situ measurements of pore water $\mathrm{O}_{2}, \mathrm{pH}$, and $\mathrm{CO}_{2}(\mathrm{aq})$, Geochim. Cosmochim. Acta, 61, $501-514,1997$.

Herguera, J. C., E. Jansen, and W. H. Berger, Evidence for a bathyal front at $2000-\mathrm{m}$ depth in the glacial Pacific, based on a depth transect on Ontong Java Plateau, Paleoceanography, 7, 273-288, 1992.

Hiramatsu, C., and P. De Deckker, The late Quaternary calcareous nannoplankton assemblages from three cores from the Tasman Sea, Palaeogeogr., Palaeoclim., Palaeoecol., 131, 391-412, 1997.

Jahnke, R. A., D. B. Craven, and J.-F. Gaillard, The influence of organic matter diagenesis on $\mathrm{CaCO}_{3}$ dissolution at the deep-sea floor, Geochim. Cosmochim. Acta, 58, 2799$2809,1994$.

Keeling, C. D., and T. P. Whorf, Atmospheric $\mathrm{CO}_{2}$ records from sites in the $\mathrm{SIO}$ air sampling network, in Trends '93, A Compendium of Data on Global Change, edited by T. A. Boden et al., pp. 16-27, U.S. Department of Energy, Oak Ridge, 1994. 
Keigwin, L. D., Glacial-age hydrography of the far northwest Pacific Ocean, Paleoceanography, 13, 323-339, 1998.

Keigwin, L. D., G. A. Jones, and P. N. Froelich, A 15,000 year paleoenvironmental record from Meiji Seamount, far northwest Pacific, Earth Planet. Sci. Lett., I11, 425-440, 1992.

Keir, R. S., On the late Pleistocene ocean geochemistry and circulation, Paleoceanography, 3, 413-445, 1988.

Keir, R. S., and W. H. Berger, Late Holocene carbonate dissolution in the equatorial Pacific: Reef growth or neoglaciation?, in The Carbon Cycle and Atmospheric $\mathrm{CO}_{2}$ : Natural Variations Archean to Present, Geophys. Monogr. Ser., Vol. 32, edited by E. T. Sundquist and W. S. Broecker, pp. 208-220, AGU, Washington, 1985.

Kroopnick, $\mathrm{P}$. , The dissolved $\mathrm{O}_{2}-\mathrm{CO}_{2}{ }^{13} \mathrm{C}$ system in the eastern equatorial Pacific, DeepSea Res. A, 21, 211-227, 1974.

Le, J., A. C. Mix, and N. J. Shackleton, Late Quaternary paleoceanography in the eastern equatorial Pacific Ocean from planktonic foraminifers: a high-resolution record from Site 846, in Proc. of the Ocean Drilling Program, Sci. Results, 138, edited by N. G. Pisias et al., pp. 675-694, NSF, Washington, 1995.

Lonsdale, P., Abyssal circulation of the southeastern Pacific and some geological implications, J. Geophys. Res., 81, 1163-1176, 1976.

Lorens, R. B., D. F. Williams, and M. L. Bender, The early nonstructural chemical diagenesis of foraminiferal calcite, J. Sediment. Petrol., 47, 1602-1609, 1977.

Mackensen, A., H.-W. Hubberten, T. Bickert, G. Fischer, and D. K. Fütterer, The $\delta^{13} \mathrm{C}$ in benthic foraminiferal tests of Fontbotia wuellerstorfi (Schwager) relative to the $\delta^{13} \mathrm{C}$ of dissolved inorganic carbon in Southern Ocean deep water: Implications for glacial ocean circulation models, Paleoceanography, 8, 587-610, 1993.

Martin, J. H., and S. E. Fitzwater, Iron deficiency limits phytoplankton growth in the north-east Pacific subarctic, Nature, 331, 341-343, 1988.

Martin, P. A., and D. W. Lea, Comparison of water mass changes in the deep tropical Atlantic derived from $\mathrm{Cd} / \mathrm{Ca}$ and carbon isotope records: Implications for changing Ba composition of deep Atlantic water masses, Paleoceanography, 13, 572-585, 1998. 
Martin, W. R., and F. L. Sayles, $\mathrm{CaCO}_{3}$ dissolution in sediments of the Ceara Rise, western equatorial Atlantic, Geochim. Cosmochim. Acta, 60, 243-263, 1996.

Matsumoto, K., and J. Lynch-Stieglitz, Similar glacial and Holocene deep water circulation inferred from southeast Pacific benthic foraminiferal carbon isotope composition, Paleoceanography, 14, 149-163, 1999.

Mayer, L. A., et al., Site 849, in Proc. of the Ocean Drilling Program, Init. Rep. Part II, 138, edited by L. A. Mayer et al., pp. 735-807, NSF, Washington, 1992.

McCorkle, D. M., and L. D. Keigwin, Depth profiles of $\delta^{13} \mathrm{C}$ in bottom water and core top C. wuellerstorfi on the Ontong Java Plateau and Emperor Seamounts, Paleoceanography, 9, 197-208, 1994.

McCorkle, D. M., P. A. Martin, B. H. Corliss, D. W. Lea, J. McManus, and G. P. Klinkhammer, Calibration studies of benthic foraminiferal isotopic and elemental composition, Eos, Transactions, AGU, 80, S172, 1999.

McKenna, V. S., J. W. Farrell, D. W. Murray, and S. C. Clemens, The foraminifer record at Site 847: paleoceanographic response to late Pleistocene climate variability, in Proc. of the Ocean Drilling Program, Sci. Results, 138, edited by N. G. Pisias et al., pp. 695-716, NSF, Washington, 1995.

Mix, A. C., N. G. Pisias, W. Rugh, J. Wilson, A. Morey, and T. K. Hagelberg, Benthic foraminifer stable isotope record from Site 849 (0-5 Ma): Local and global climate changes, in Proc. of the Ocean Drilling Program, Sci. Results, 138, edited by N. G. Pisias et al., pp. 371-412, NSF, Washington, 1995.

Mottl, M. J., and C. G. Wheat, Hydrothermal circulation through mid-ocean ridge flanks: Fluxes of heat and magnesium, Geochim. et Cosmochim. Acta, 58, 2225-2237, 1994.

Neftel, A., E. Moor, H. Oeschger, and B. Stauffer, Evidence from polar ice cores for the increase in atmospheric $\mathrm{CO}_{2}$ in the past two centuries, Nature, 315, 45-47, 1985.

Passlow, V., Quaternary ostracods as palaeoceanographic indicators: a case study off southern Australia, Palaeogeogr., Palaeoclim., Palaeoecol., 131, 315-325, 1997.

Peterson, L. C., and W. L. Prell, Carbonate preservation and rates of climatic change: An $800 \mathrm{kyr}$ record from the Indian Ocean, in The Carbon Cycle and Atmospheric $\mathrm{CO}_{2}$ : Natural Variations Archean to Present, Geophys. Monogr. Ser., Vol. 32, edited by E. T. Sundquist and W. S. Broecker, pp. 251-270, AGU, Washington, 1985. 
Rosenthal, Y., Late Quaternary paleochemistry of the Southern Ocean: Evidence from cadmium variability in sediments and foraminifera, Ph.D. thesis, Mass. Inst. of Technol./Woods Hole Oceanogr. Inst. Joint Program in Oceanogr, Cambridge, MA, 1994.

Sanyal, A., N. G. Hemming, G. N. Hanson, and W. S. Broecker, Evidence for a higher pH in the glacial ocean from boron isotopes in foraminifera, Nature, 373, 234-236, 1995.

Schrag, D. P., G. Hampt, and D. W. Murray, Pore fluid constraints on the temperature and isotopic composition of the glacial ocean, Science, 272, 1930-1932, 1996.

Shackleton, N. J., and N. G. Pisias, Atmospheric carbon dioxide, orbital forcing, and climate, in The Carbon Cycle and Atmospheric $\mathrm{CO}_{2}$ : Natural Variations Archean to Present, Geophys. Monogr. Ser., Vol. 32, edited by E. T. Sundquist and W. S. Broecker, pp. 303-318, AGU, Washington, 1985.

Shackleton, N. J., J. Imbrie, and M. A. Hall, Oxygen and carbon isotope record of East Pacific core V19-30: implications for the formation of deep water in the late Pleistocene North Atlantic, Earth Planet. Sci. Lett., 65, 233-244, 1983.

Shiller, A. M., and E. Boyle, Dissolved zinc in rivers, Nature, 317, 49-52, 1985.

Sigman, D. M., D. C. McCorkle, and W. R. Martin, The calcite lysocline as a constraint on glacial/interglacial low-latitude production changes, Global Biogeochem. Cycles, 12, 409-427, 1998.

Toggweiler, J. R., Variation of atmospheric $\mathrm{CO}_{2}$ by ventilation of the ocean's deepest water, Paleoceanography, 14, 571-588, 1999.

Zahn, R., K. Wynn, and M. Sarnthein, Benthic foraminiferal $\delta^{13} \mathrm{C}$ and accumulation rates of organic carbon: Uvigerina peregrina group and Cibicidoides wuellerstorfi, Paleoceanography, $1,27-42,1986$. 


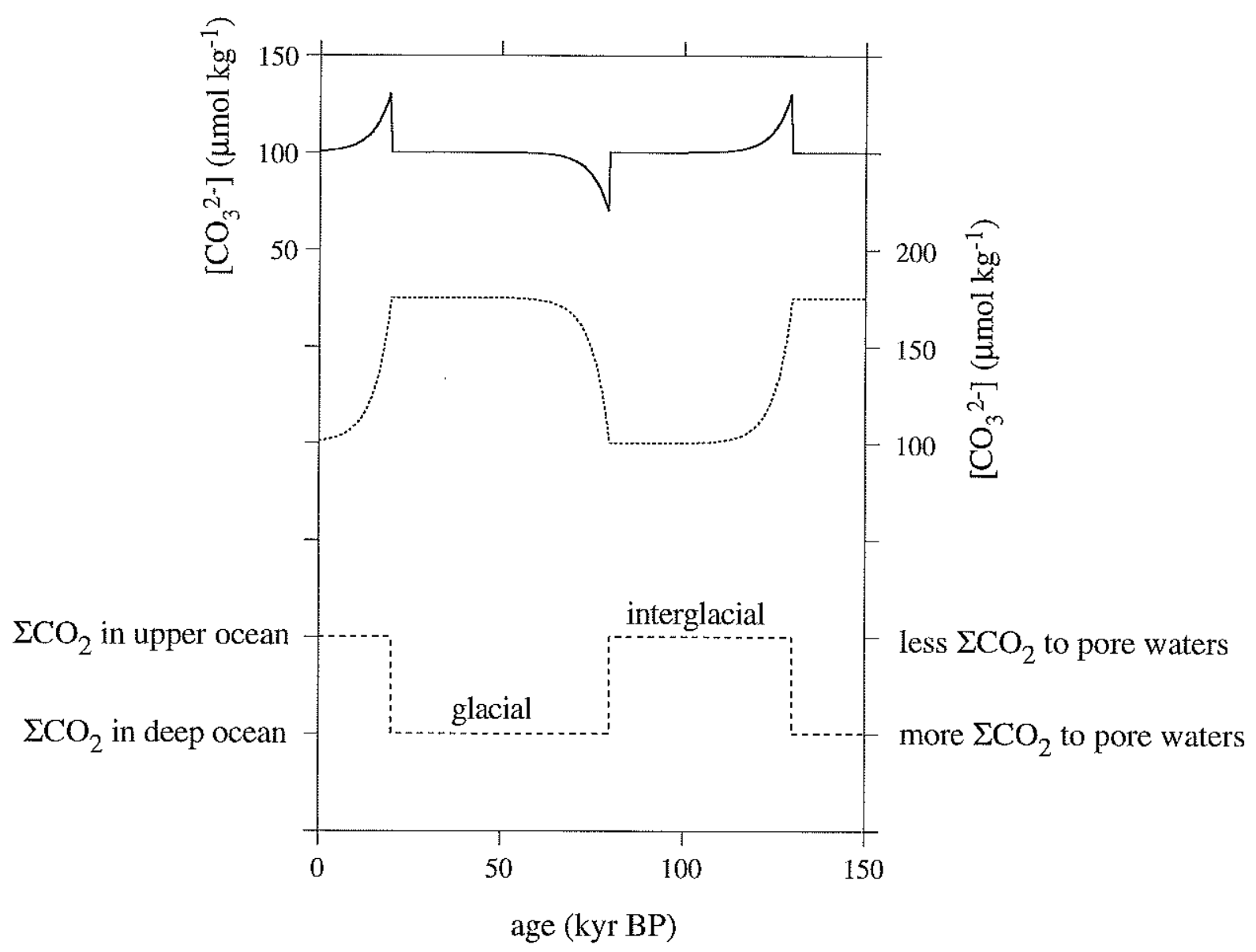

Figure 3.1. Predicted deep Pacific $\left[\mathrm{CO}_{3}{ }^{2-}\right]$ responses to two types of $\mathrm{CaCO}_{3}$ compensation models used to explain glacial/interglacial atmospheric $\mathrm{CO}_{2}$ cycles (simple hypothetical forcing for both is shown by dashed square wave). Solid curve is response to transferring $\Sigma \mathrm{CO}_{2}$ between intermediate and deep waters (Boyle, 1988b). Dotted curve is response to increasing the $\mathrm{C}_{\text {org }}: \mathrm{CaCO}_{3}$ ratio of material reaching sediments (Archer and Maier-Reimer, 1994). Neither curve models basin-to-basin transfers due to changing NADW fluxes. $\left[\mathrm{CO}_{3}^{2-}\right]$ values are very approximate, and will depend on various model parameters. 


\section{ODP Site 849}

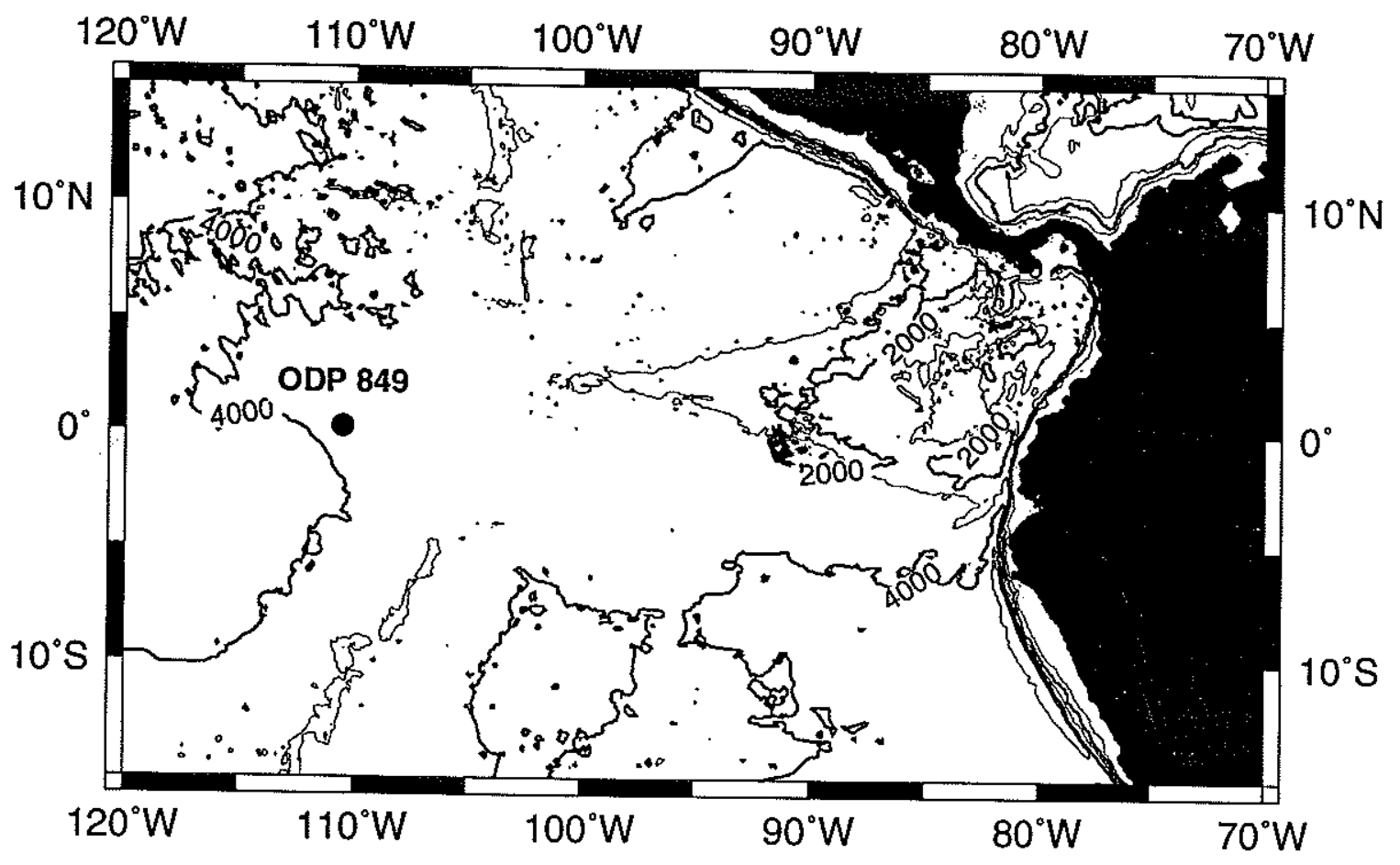

Figure 3.2. Location of ODP Site 849 in the eastern equatorial Pacific. 

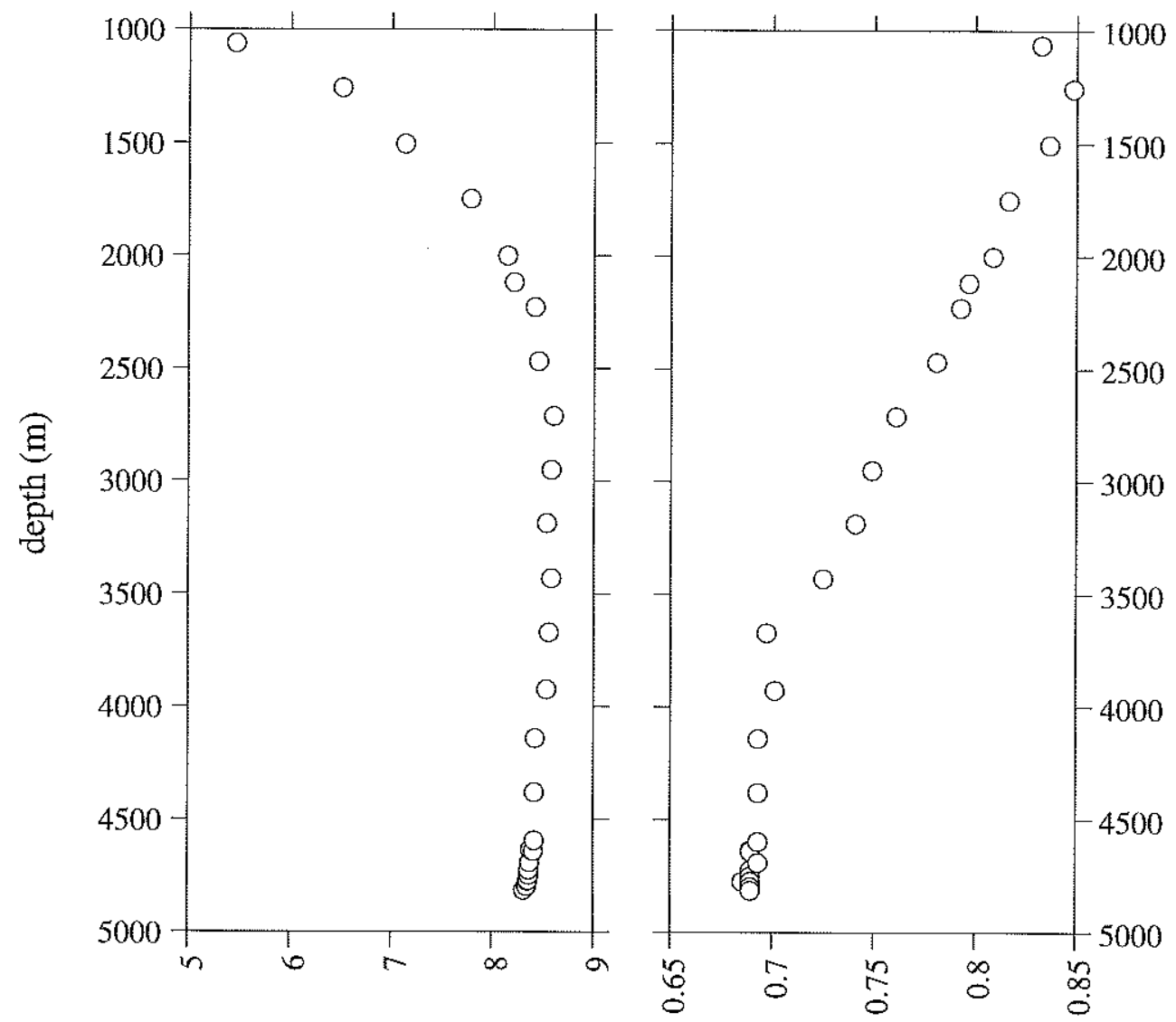

$[\mathrm{Zn}]\left(\mathrm{nmol} \mathrm{kg}^{-1}\right)$

[Cd] $(\mathrm{nmol} \mathrm{kg}-1)$

Figure 3.3. Vertical profiles of dissolved $\mathrm{Zn}$ (left) and $\mathrm{Cd}$ (right) estimated from GEOSECS Station 334 (0N, 125W) Si and P measurements, respectively (Broecker et al., 1982). 


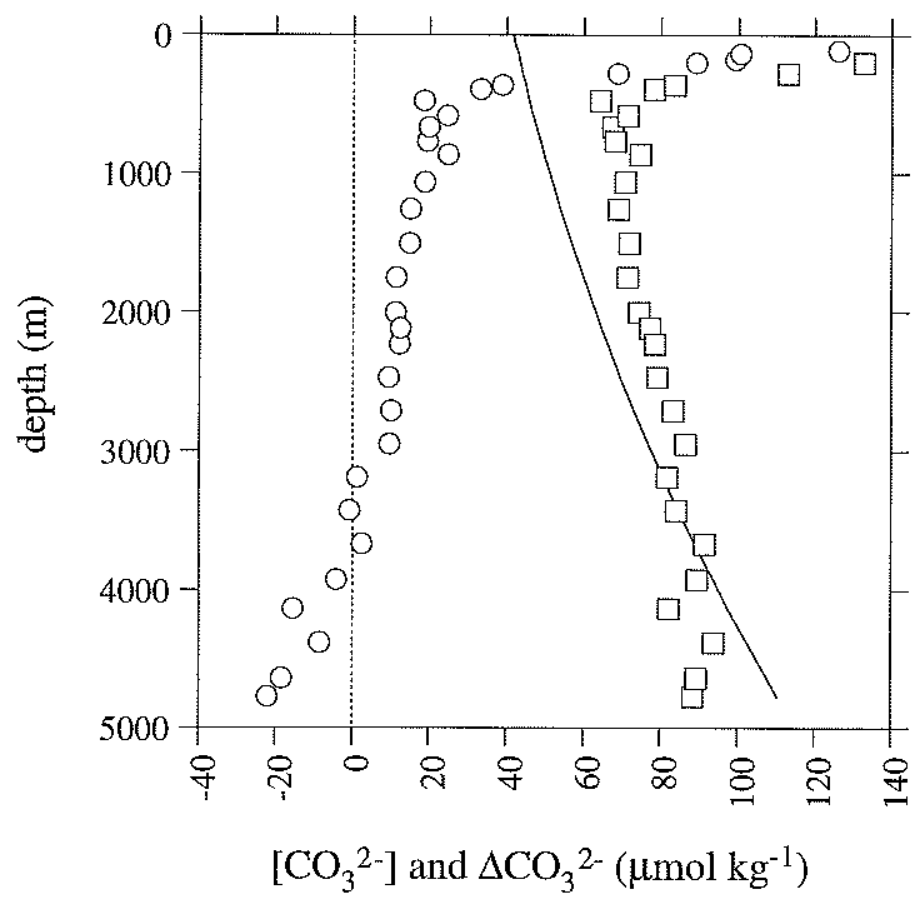

Figure 3.4. $\mathrm{CO}_{3}{ }^{2-}$ concentrations (squares) and calcitic $\Delta \mathrm{CO}_{3}{ }^{2-}$ values (circles) calculated using data from the nearest GEOSECS station to ODP 849 (Station 334; Broecker et al., 1982). Solid line is $\left[\mathrm{CO}_{3}{ }^{2-}\right]_{\text {saturation }}$ with respect to calcite. 


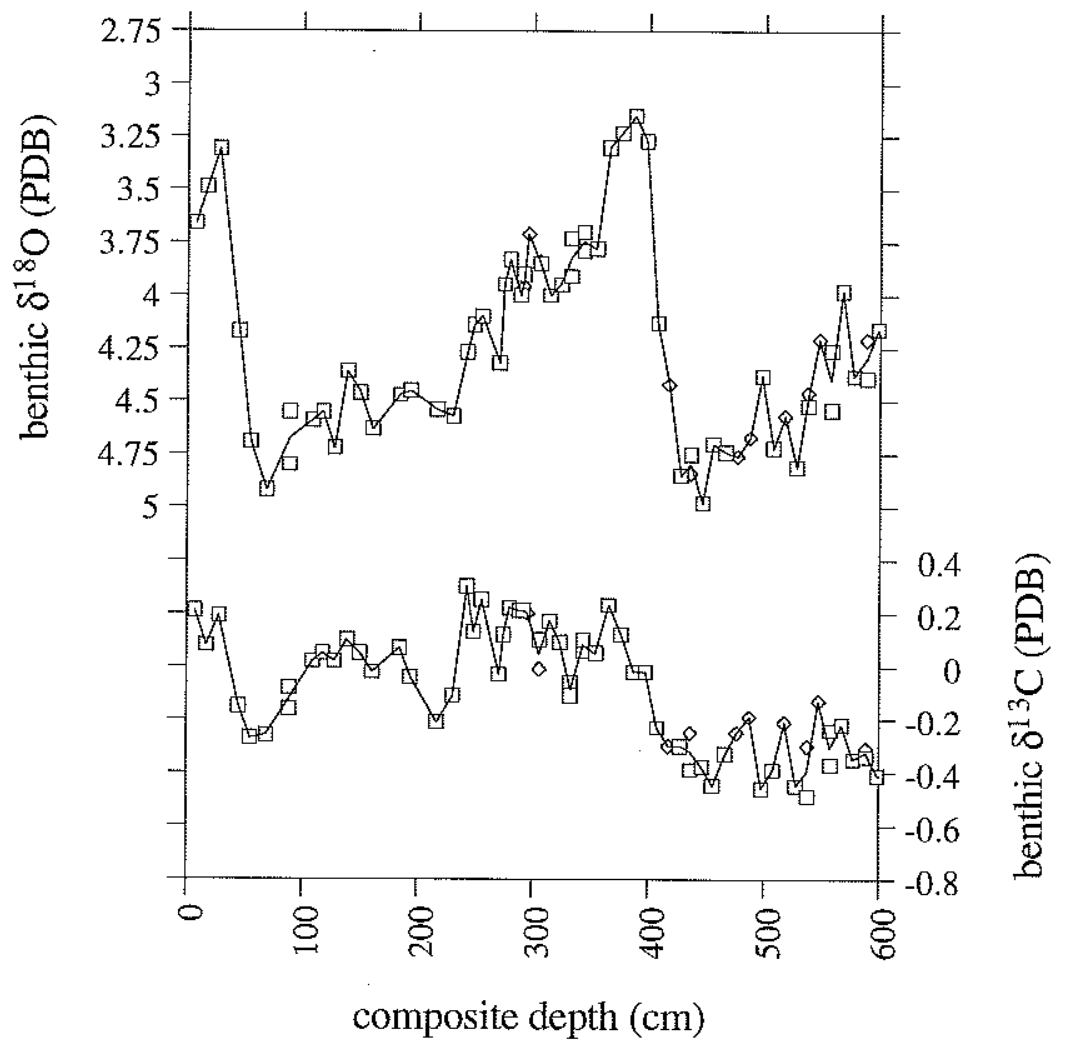

Figure 3.5. ODP 849 benthic foraminiferal stable isotope data as presented by Mix $e t$ al. (1995). C. wuellerstorfi (squares) $\delta^{18} \mathrm{O}$ data are shifted by +0.64 per mil to agree with $U$. peregrina (diamonds). U. peregrina $\delta^{13} \mathrm{C}$ data are shifted by +0.90 per mil. 

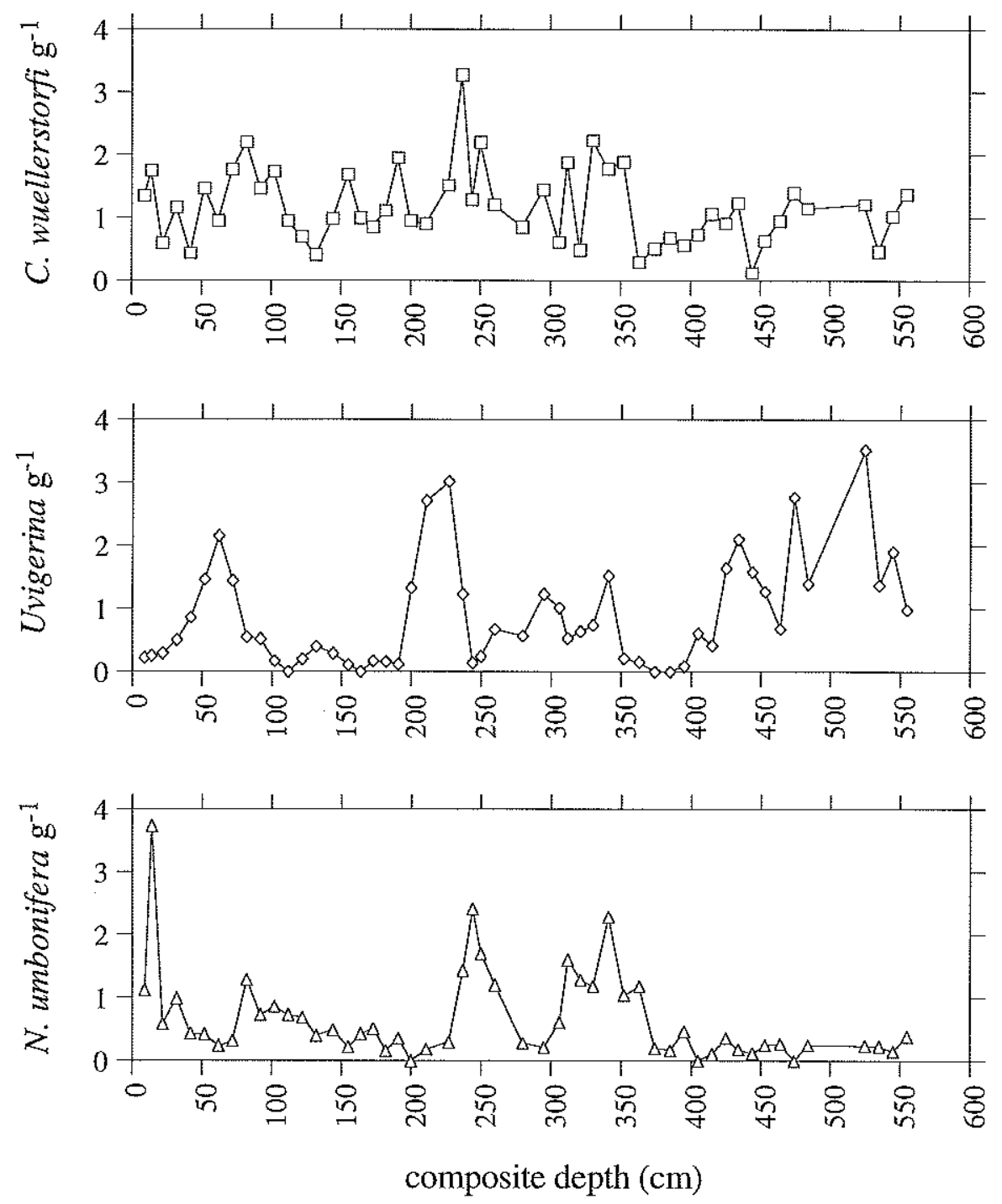

Figure 3.6. Abundances of benthic foraminifera $(>250 \mu \mathrm{m})$ per gram of dry bulk sediment in ODP 849. Average sample size was about $7 \mathrm{~g}$. 


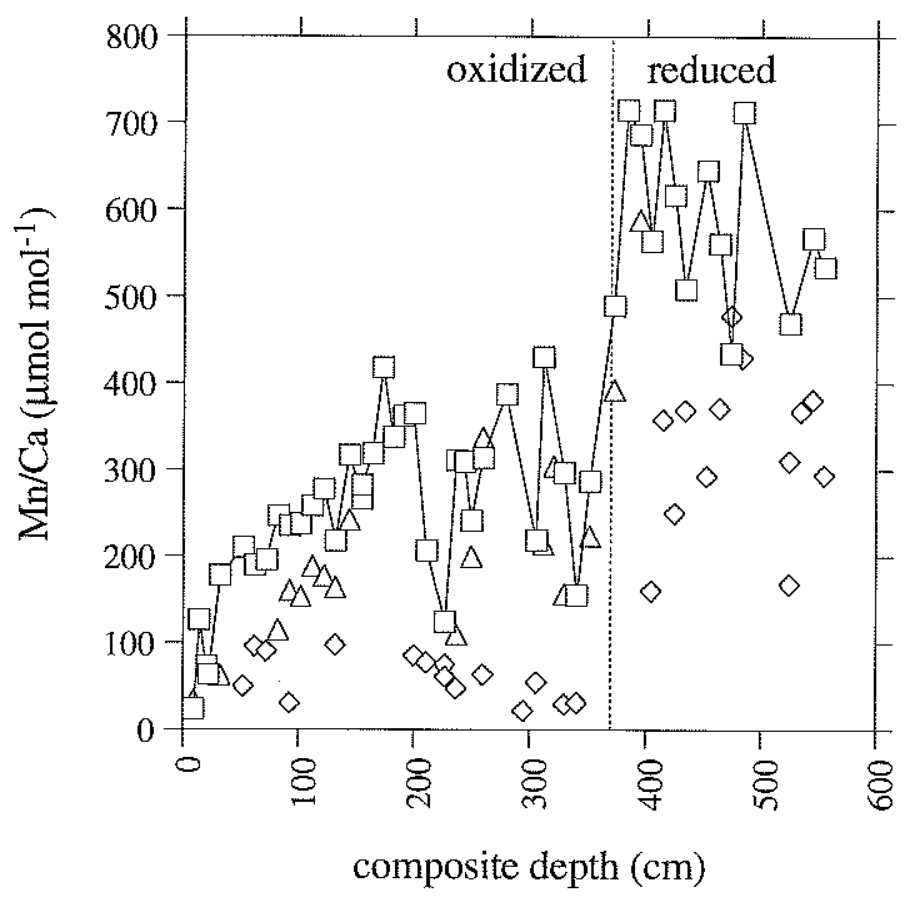

Figure 3.7. $\mathrm{Mn} / \mathrm{Ca}$ ratios in C. wuellerstorfi (squares), $N$. umbonifera (triangles), and Uvigerina (diamonds) from ODP 849. Dotted line is the redox boundary estimated from these data, and is close to the visual redox boundary identified at $\sim 400 \mathrm{~cm}$ by Mayer et al. (1992). 

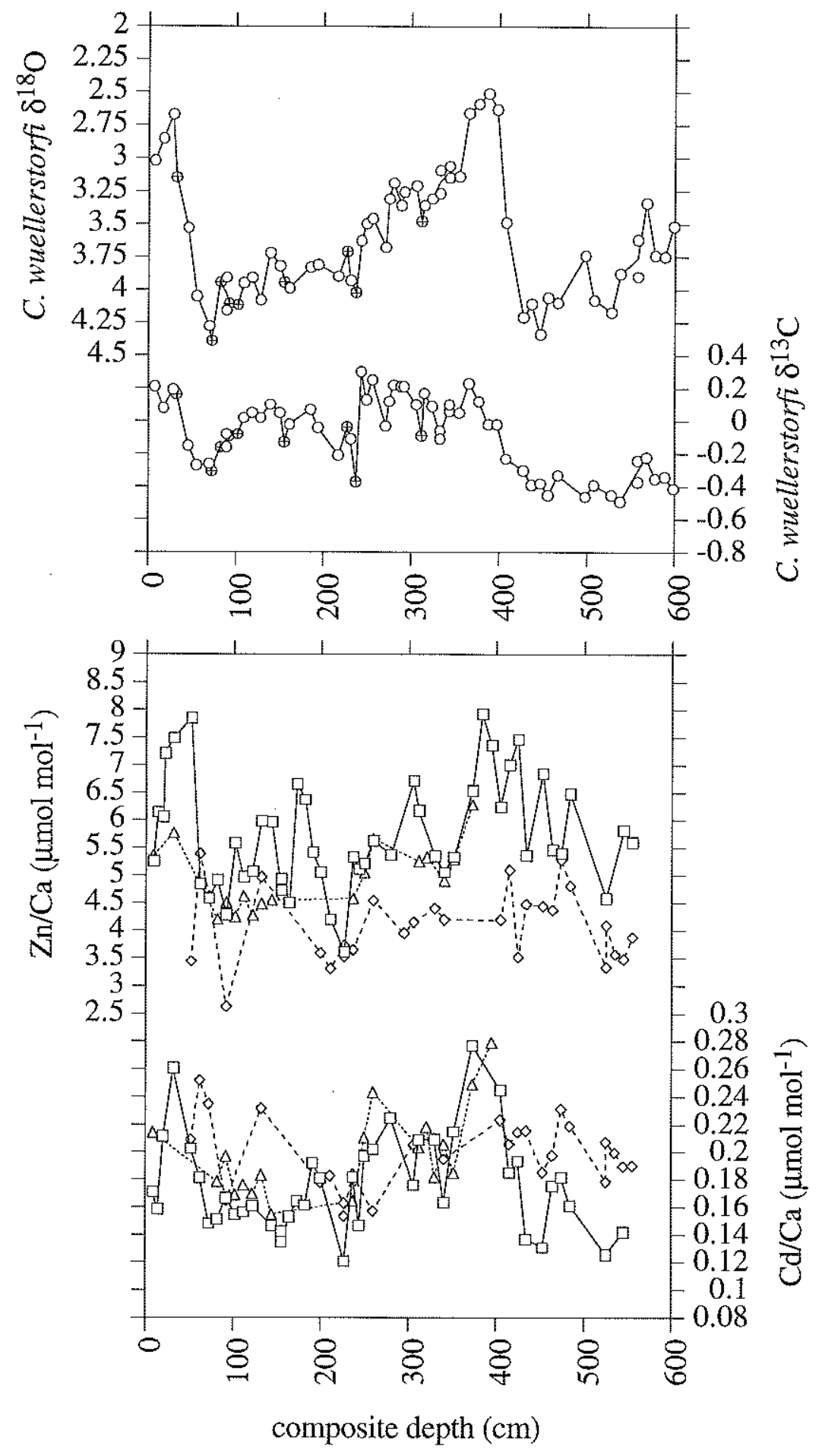

Figure 3.8. $\mathrm{Zn} / \mathrm{Ca}$ and $\mathrm{Cd} / \mathrm{Ca}$ ratios in C. wuellerstorfi (squares), N. umbonifera (triangles), and Uvigerina (diamonds) from ODP 849 (bottom panel). Also shown (top panel) are unshifted $C$. wuellerstorfi stable isotope data from Mix et al. (1995) (open) and this study (hatched). 


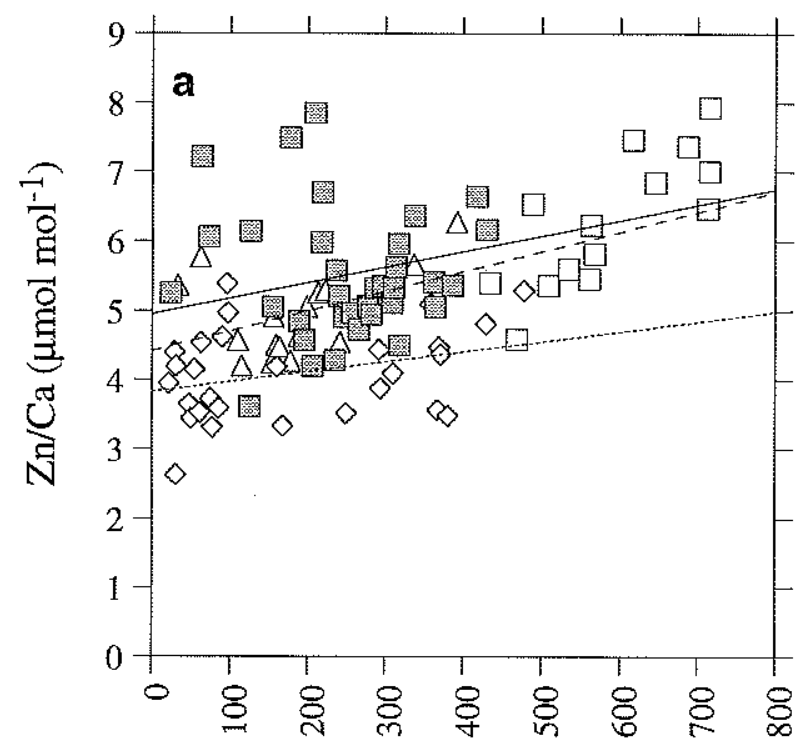

$\mathrm{Mn} / \mathrm{Ca}\left(\mu \mathrm{mol} \mathrm{mol}{ }^{-1}\right)$

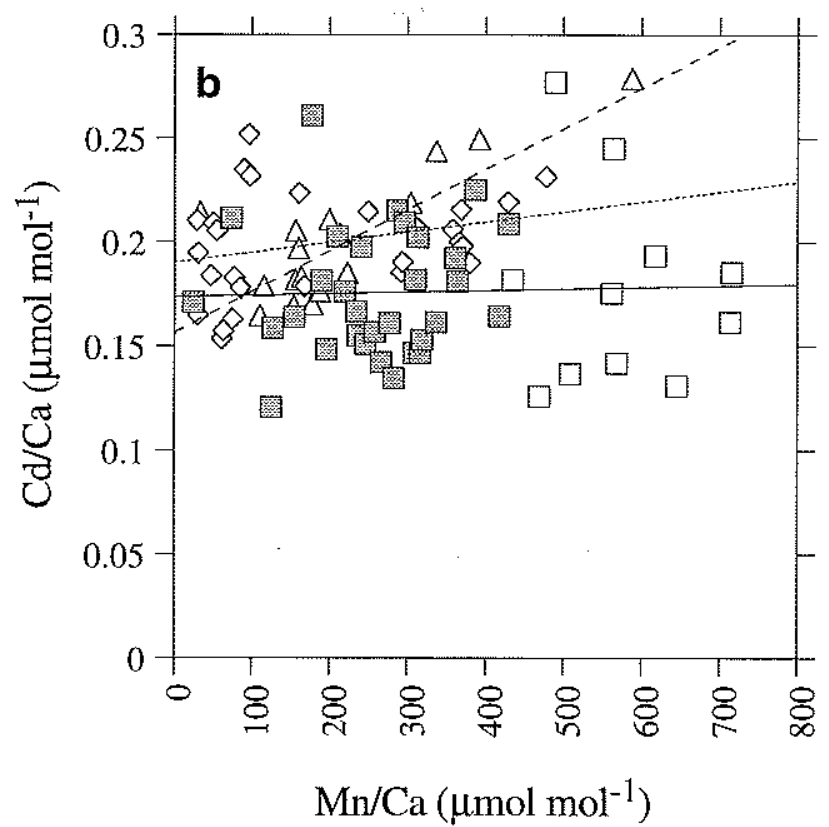

Figure 3.9. $\mathrm{Zn} / \mathrm{Ca}$ (a) and $\mathrm{Cd} / \mathrm{Ca}(\mathrm{b})$ ss. $\mathrm{Mn} / \mathrm{Ca}$ in $C$. wuellerstorfi (squares, solid lines), N. umbonifera (triangles, dashed lines), and Uvigerina (diamonds, dotted lines) from ODP 849. Two correlations have significance probabilities lower than 0.05: $\mathrm{Zn} / \mathrm{Ca}$ in $C$. wuellerstorfi $\left(\mathrm{r}^{2}=0.17, \mathrm{p}=0.004\right)$ and $\mathrm{Cd} / \mathrm{Ca}$ in $N$. umbonifera $\left(\mathrm{r}^{2}=0.56\right.$, $\mathrm{p}=0.0003$ ). However, when only data shallower than $370 \mathrm{~cm}$ are considered, the $C$. wuellerstorfi $\mathrm{Zn} / \mathrm{Ca}$ correlation decreases to $\mathrm{r}^{2}=0.001, \mathrm{p}=0.85$ (shaded squares). 


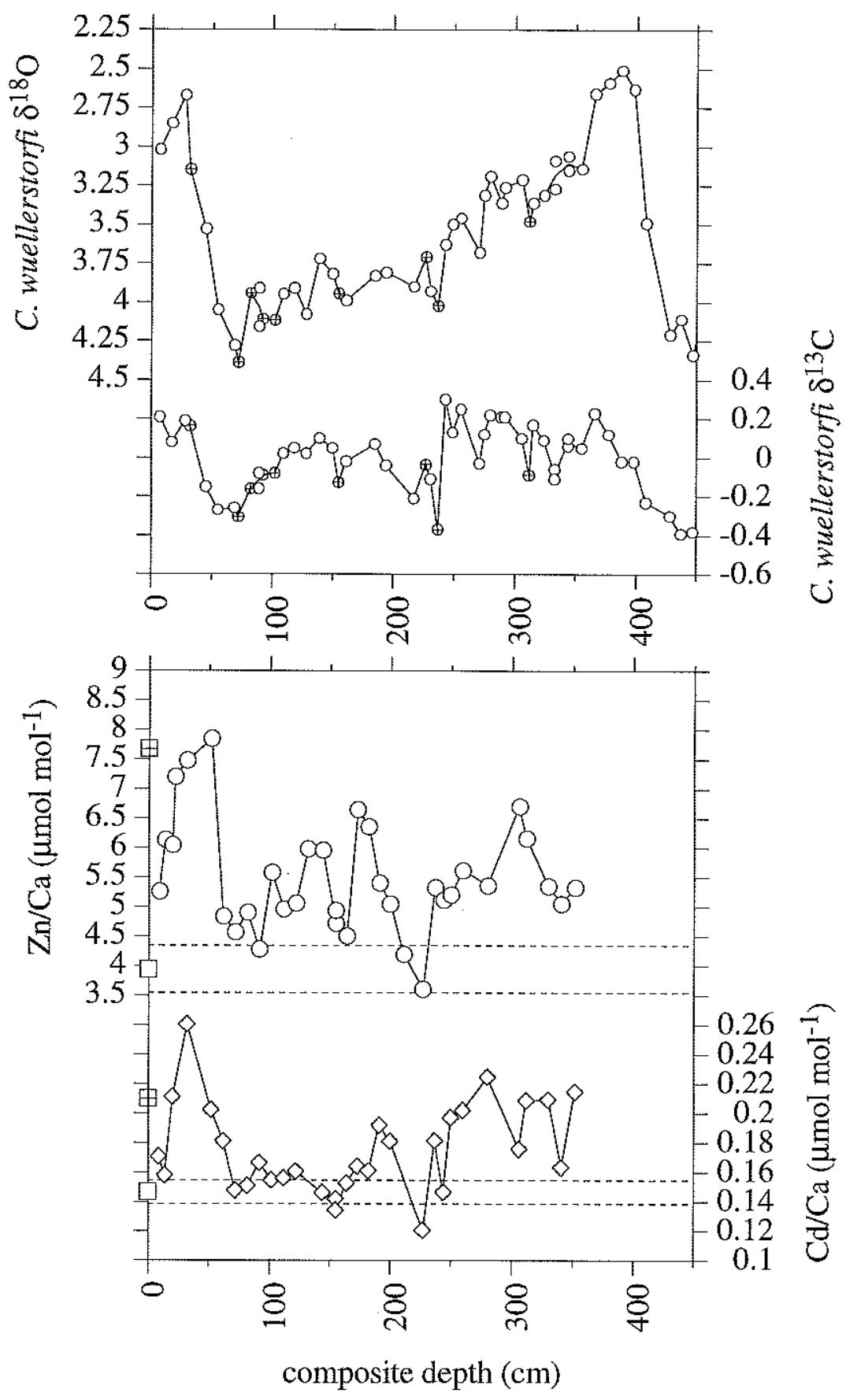

Figure 3.10. $\mathrm{Zn} / \mathrm{Ca}$ and $\mathrm{Cd} / \mathrm{Ca}$ ratios in C. wuellerstorfi from the upper $370 \mathrm{~cm}$ of ODP 849 (bottom panel). Open squares show values predicted from modern dissolved $\mathrm{Si}\left(149 \mu \mathrm{mol} \mathrm{kg}^{-1}\right), \mathrm{P}\left(2.40 \mu \mathrm{mol} \mathrm{kg}{ }^{-1}\right)$, and $\Delta \mathrm{CO}_{3}{ }^{2-}\left(-4 \mu \mathrm{mol} \mathrm{kg}^{-1}\right)$. Hatched squares show expected values if $D_{\mathrm{Zn}}$ were 9 (i.e., if $\Delta \mathrm{CO}_{3}{ }^{2-}$ were $>25 \mu \mathrm{mol} \mathrm{kg}^{-1}$ ) and if $D_{\mathrm{Cd}}$ were $3\left(\Delta \mathrm{CO}_{3}{ }^{2-}>5 \mu \mathrm{mol} \mathrm{kg}^{-1}\right)$. Dashed lines are approximate ranges of variability predicted from $\delta^{13}$ C. Also shown (top panel) are C. wuellerstorfi stable isotope data as in Figure 3.8. 

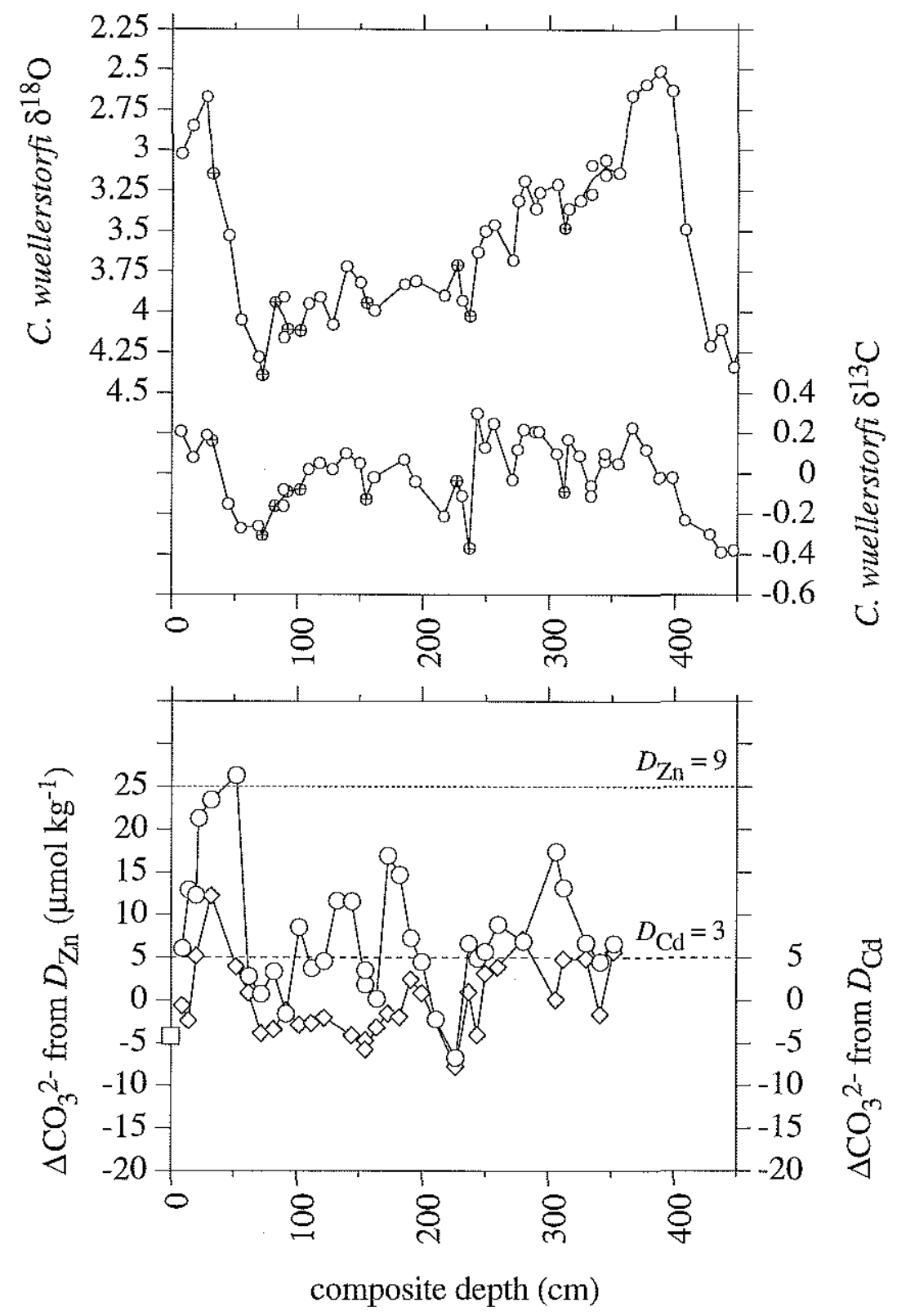

Figure 3.11. $\Delta \mathrm{CO}_{3}{ }^{2-}$ values inferred from $C$. wuellerstorfi $\mathrm{Zn} / \mathrm{Ca}$ (circles) and $\mathrm{Cd} / \mathrm{Ca}$ (diamonds), assuming constant seawater dissolved $\mathrm{Zn}$ and $\mathrm{Cd}$ concentrations (bottom panel). Modern value calculated from GEOSECS data is shown by square. Dotted line is the maximum value that $\mathrm{Zn} / \mathrm{Ca}$ can record (equivalent to $D_{\mathrm{Zn}}=9$ ), and dashed line is the maximum value that $\mathrm{Cd} / \mathrm{Ca}$ can record $\left(D_{\mathrm{Cd}}=3\right)$. Also shown (top panel) are C. wuellerstorfi stable isotope data as in Figure 3.8. 


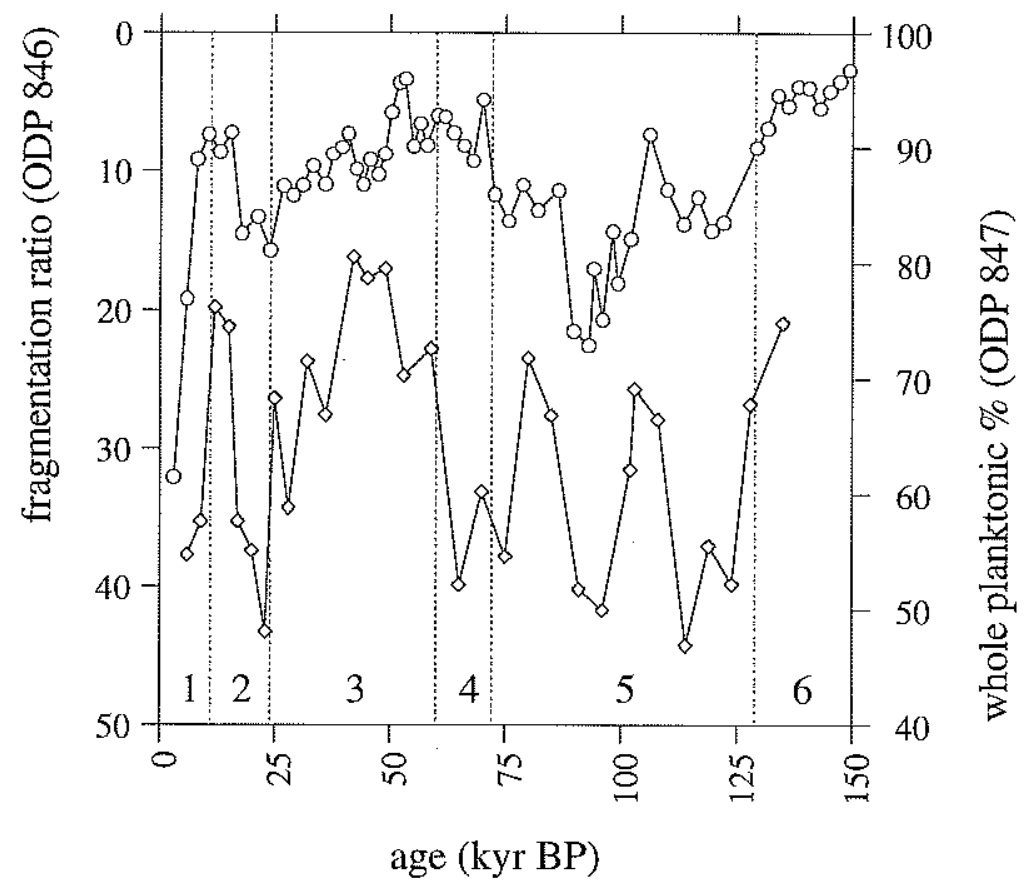

Figure 3.12. Foraminiferal fragmentation indices in deep eastern equatorial Pacific cores ODP 846 (circles; Le et al., 1995) and ODP 847 (diamonds; McKenna et al., 1995). Better preservation is up. Dotted lines indicate MIS boundaries based on $\delta^{18} \mathrm{O}$ data. 


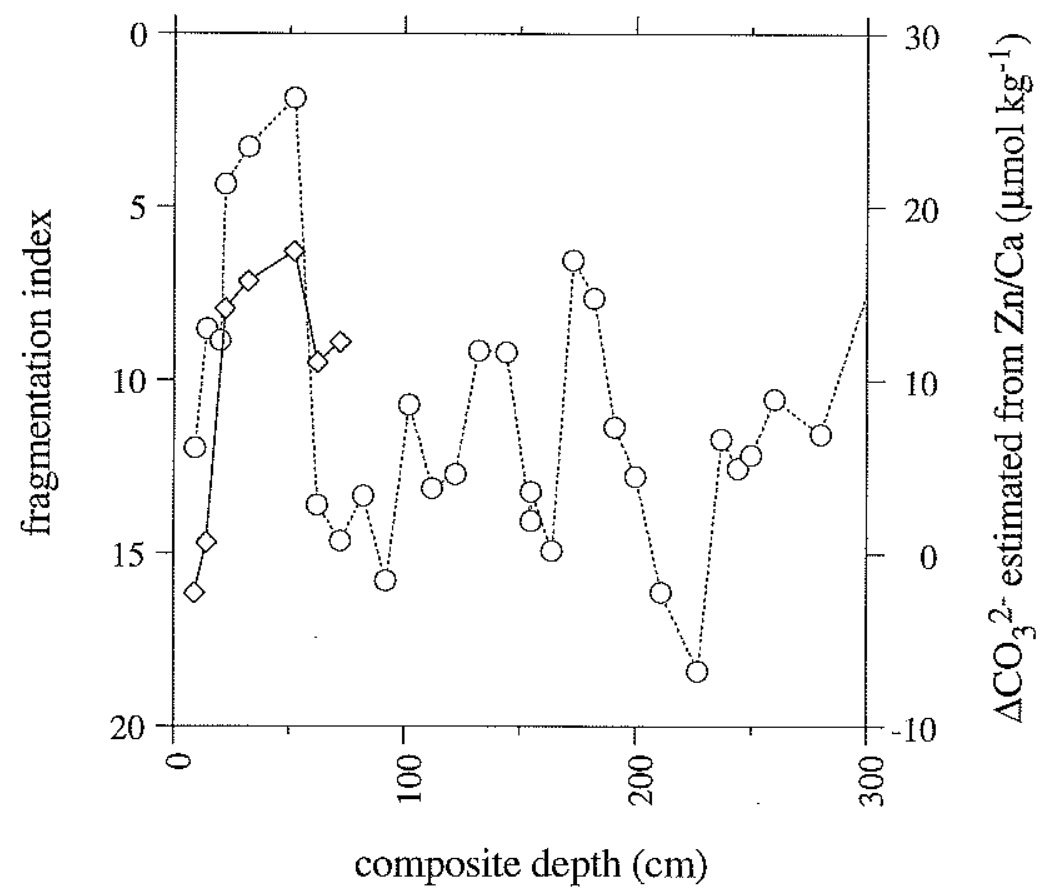

Figure 3.13. Foraminiferal fragmentation index (diamonds) measured in the upper portion of ODP 849 following the methods of Le et al. (1995) (better preservation is up). Also shown is the record of $\Delta \mathrm{CO}_{3}{ }^{2-}$ inferred from $\mathrm{Zn} / \mathrm{Ca}$ (circles). 


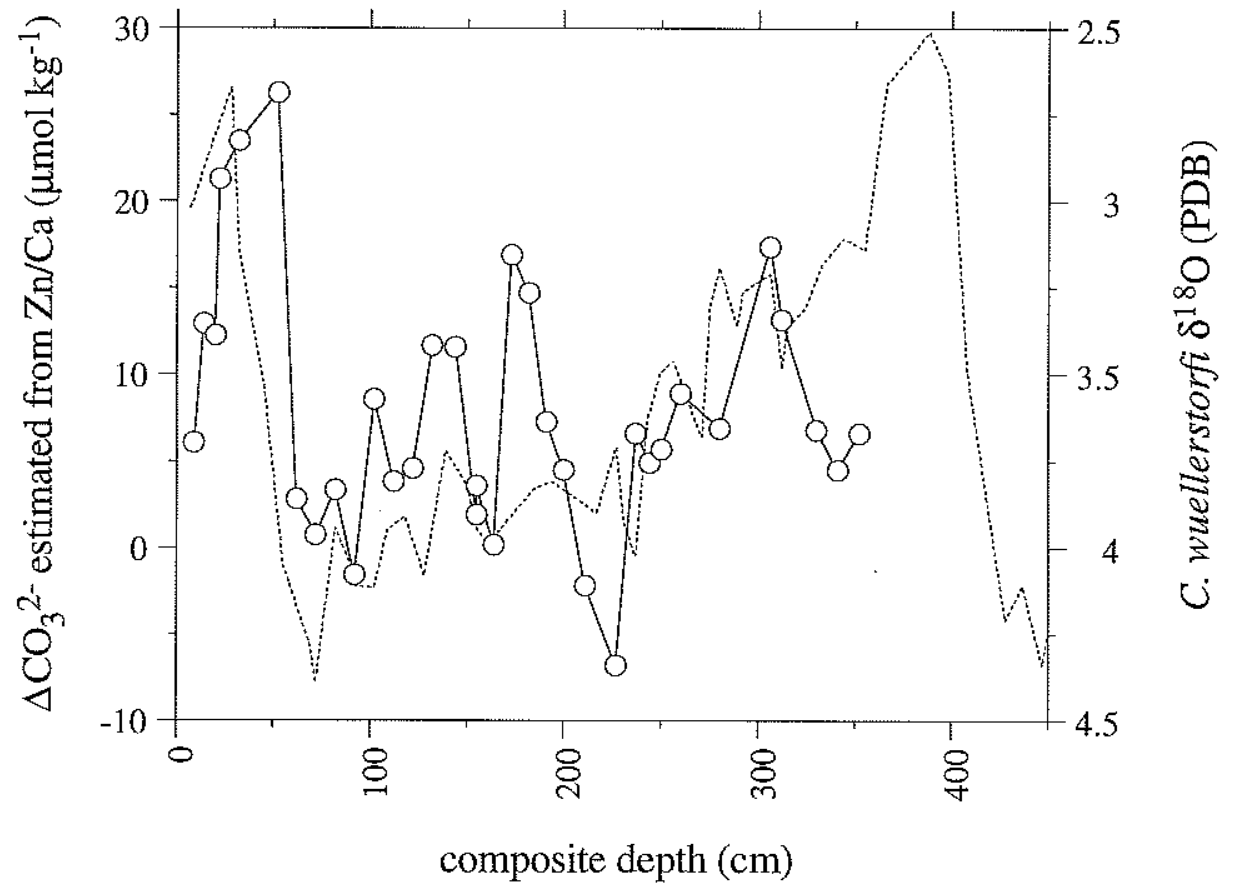

Figure 3.14. Overlay of C. wuellerstorfi $\Delta \mathrm{CO}_{3}{ }^{2-}$ (circles) and $\delta^{18} \mathrm{O}$ (dotted line) records to compare timing of major changes. 

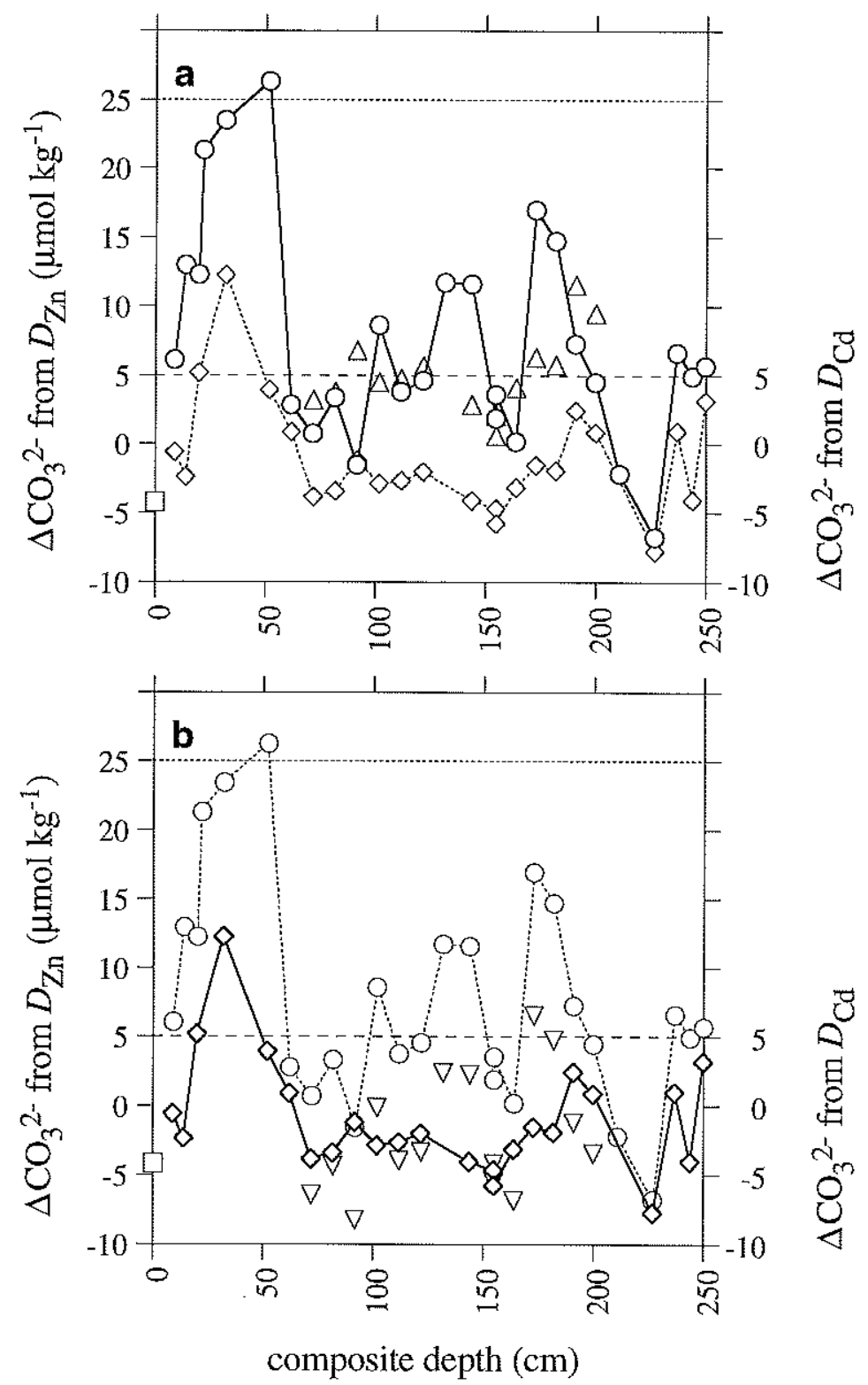

Figure 3.15. (a) $\mathrm{CO}_{3}{ }^{2-}$ estimates from $\mathrm{Zn} / \mathrm{Ca}$ and $\mathrm{Cd} / \mathrm{Ca}$ assuming modern seawater $[\mathrm{Zn}]$ (circles), modern seawater $[\mathrm{Cd}]$ (diamonds), and a seawater $[\mathrm{Cd}]$ decrease of $25 \%$ during MIS 2 and 3 (between 72 and $200 \mathrm{~cm}$ ) (triangles). (b) circles and diamonds same as panel (a), with seawater [Zn] increased by $25 \%$ during MIS 2 and 3 (inverted triangles). In each panel, modern $\Delta \mathrm{CO}_{3}{ }^{2-}$ value calculated from GEOSECS data is shown by square. Dotted line is the maximum value that $\mathrm{Zn} / \mathrm{Ca}$ can record (equivalent to $D_{\mathrm{Zn}}=9$ ), and dashed line is the maximum value that $\mathrm{Cd} / \mathrm{Ca}$ can record $\left(D_{\mathrm{Cd}}=3\right)$. 

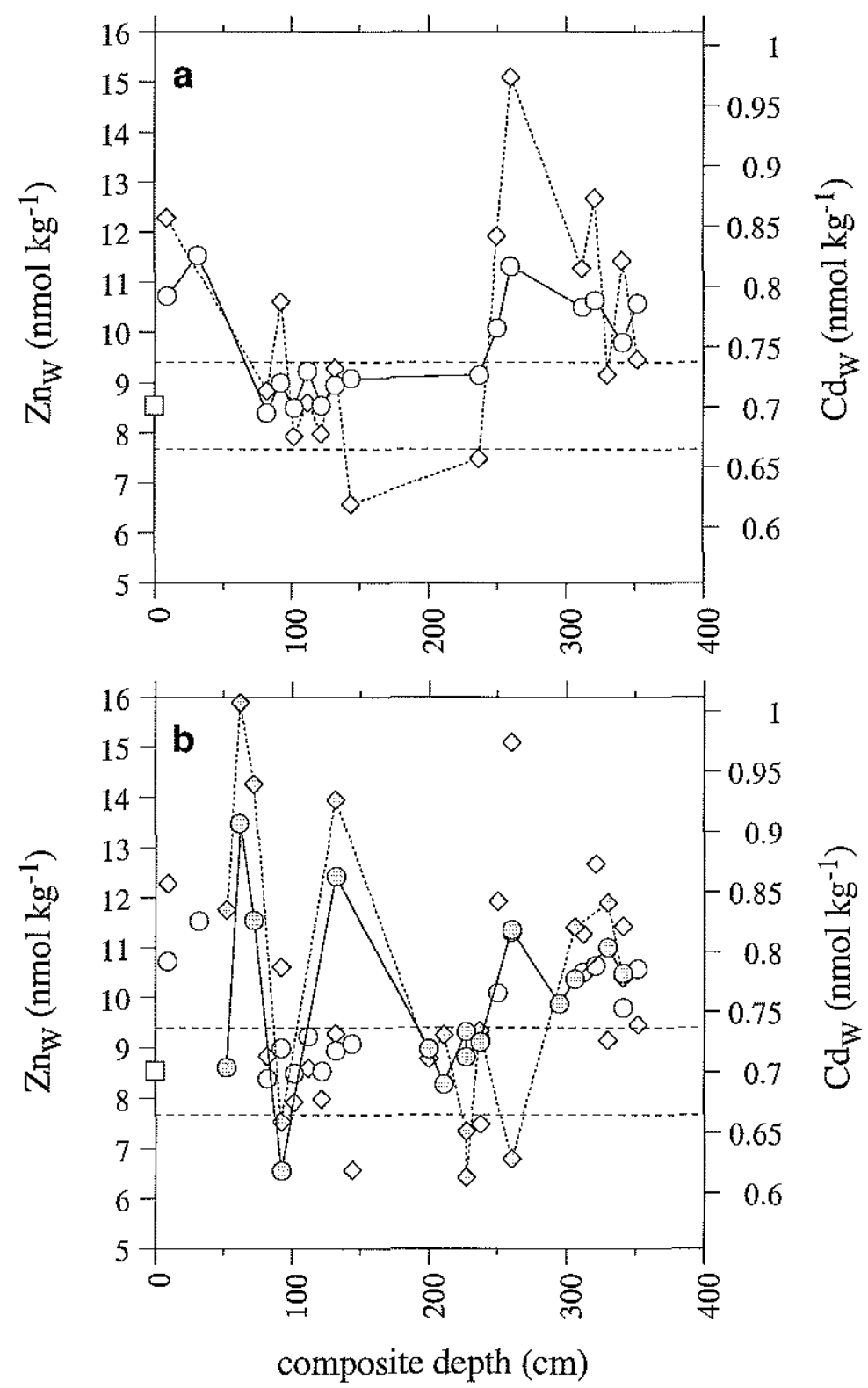

Figure 3.16. (a) $N$. umbonifera $\mathrm{Zn}_{\mathrm{W}}$ (circles) and $\mathrm{Cd}_{\mathrm{W}}$ (diamonds) estimates using constant partition coefficients of 5 and 2.5 respectively. (b) Uvigerina $\mathrm{Zn}_{\mathrm{W}}$ (shaded circles) and $\mathrm{Cd}_{\mathrm{W}}$ (shaded diamonds) estimates using constant partition coefficients of 4 and 2.5 respectively (open symbols are $N$. umbonifera data as in panel [a]). In each panel, $\mathrm{Zn}_{\mathrm{W}}$ and $\mathrm{Cd}_{\mathrm{W}}$ are scaled to each other according to their relationship in the modern deep Pacific, and dashed lines represent possible ranges of variability estimated from benthic $\delta^{13} \mathrm{C}$. Squares mark the modern estimated seawater values. 
Table 3.1. All benthic foraminiferal trace metal data from ODP 849 (sections B-1H-1,2; C-1H-2,3)

\begin{tabular}{|c|c|c|c|c|c|c|c|c|c|c|c|c|}
\hline \multirow[b]{2}{*}{ depth } & \multicolumn{4}{|c|}{ C. wuellerstorfi } & \multicolumn{4}{|c|}{ N. umbonifera } & \multicolumn{4}{|c|}{ Uvigerina spp. } \\
\hline & [Ca] & $\mathrm{Zn} / \mathrm{Ca}$ & $\mathrm{Cd} / \mathrm{Ca}$ & $\mathrm{Mn} / \mathrm{Ca}$ & {$[\mathrm{Ca}]$} & $\mathrm{Zn} / \mathrm{Ca}$ & $\mathrm{Cd} / \mathrm{Ca}$ & $\mathrm{Mn} / \mathrm{Ca}$ & {$[\mathrm{Ca}]$} & $\mathrm{Zn} / \mathrm{Ca}$ & $\mathrm{Cd} / \mathrm{Ca}$ & $\mathrm{Mn} / \mathrm{Ca}$ \\
\hline 9 & 18.43 & 5.26 & 0.171 & 23.9 & 4.81 & 5.37 & 0.214 & 33.4 & & & & \\
\hline 14 & 12.74 & 6.14 & 0.158 & 126.8 & & & & & & & & \\
\hline 20 & 7.88 & 6.06 & 0.211 & 73.0 & & & & & & & & \\
\hline 22 & 1.89 & 7.21 & 0.107 & 63.6 & & & & & & & & \\
\hline 32 & 24.09 & 7.49 & 0.261 & 177.0 & 5.64 & 5.77 & $\underline{0.301}$ & 62.4 & & & & \\
\hline 52 & 6.52 & 7.85 & 0.203 & 209.6 & & & & & 13.90 & 3.45 & 0.209 & 50.1 \\
\hline 62 & 4.84 & 4.84 & 0.181 & 189.7 & & & & & 12.85 & 5.39 & 0.252 & 96.0 \\
\hline 72 & 16.97 & 4.58 & 0.148 & 195.8 & & & & & 10.32 & 4.62 & 0.235 & 90.3 \\
\hline 82 & 13.13 & 4.91 & 0.151 & 246.6 & 16.39 & 4.20 & 0.178 & 115.1 & & & & \\
\hline 92 & 8.18 & 4.28 & 0.167 & 234.9 & 16.35 & 4.50 & 0.197 & 159.8 & 16.86 & 2.63 & 0.165 & 30.5 \\
\hline 102 & 14.88 & 5.58 & 0.155 & 236.9 & 12.12 & 4.25 & 0.169 & 153.6 & & & & \\
\hline 112 & 18.92 & 4.97 & 0.156 & 257.9 & 10.85 & 4.62 & 0.176 & 187.7 & & & & \\
\hline 122 & 8.19 & 5.07 & 0.161 & 277.6 & 11.65 & 4.27 & 0.169 & 177.7 & & & & \\
\hline 132 & 2.03 & 5.98 & 0.105 & 218.0 & 8.38 & 4.48 & 0.183 & 163.8 & 4.59 & 4.97 & 0.232 & 97.7 \\
\hline 144 & 11.68 & 5.97 & 0.146 & 316.7 & 4.22 & 4.54 & 0.155 & 241.7 & & & & \\
\hline \multirow[t]{2}{*}{155} & 8.62 & 4.72 & 0.142 & 266.2 & & & & & & & & \\
\hline & 9.89 & 4.94 & 0.134 & 282.4 & & & & & & & & \\
\hline 164 & 7.34 & 4.51 & 0.153 & 318.8 & & & & & & & & \\
\hline 173 & 5.22 & 6.65 & 0.164 & 417.8 & & & & & & & & \\
\hline 182 & 13.62 & 6.37 & 0.161 & 337.4 & & & & & & & & \\
\hline 191 & 18.38 & 5.41 & 0.192 & 361.8 & & & & & & & & \\
\hline 200 & .6 .86 & 5.05 & 0.181 & 364.4 & & & & & 14.82 & 3.59 & 0.178 & 85.4 \\
\hline 211 & 1.39 & 4.20 & 0.094 & 206.5 & & & & & 17.81 & 3.31 & 0.183 & 77.5 \\
\hline \multirow[t]{2}{*}{227} & 3.73 & 3.61 & 0.121 & 125.0 & & & & & 12.13 & 3.73 & 0.163 & 75.1 \\
\hline & & & & & & & & & 7.22 & 3.53 & 0.153 & 61.3 \\
\hline 237 & 16.36 & 5.33 & 0.182 & 310.5 & 10.91 & 4.58 & 0.164 & 110.1 & 5.96 & 3.65 & 0.184 & 47.4 \\
\hline 244 & 10.23 & 5.11 & 0.147 & 309.2 & & & & & & & & \\
\hline 250 & 16.10 & $5.2 \mathrm{I}$ & 0.197 & 240.5 & 19.95 & 5.05 & 0.210 & 199.4 & & & & \\
\hline 260 & 8.37 & 5.62 & 0.202 & 313.6 & 6.71 & 5.66 & 0.243 & 337.0 & 3.65 & 4.54 & 0.157 & 63.3 \\
\hline 280 & 6.01 & 5.37 & 0.225 & 386.9 & & & & & & & & \\
\hline 295 & 0.97 & 4.64 & 0.077 & 142.2 & & & & & 1.91 & 3.95 & 0.104 & 21.5 \\
\hline 306 & 4.66 & 6.71 & 0.176 & 219.2 & & & & & 4.75 & 4.15 & 0.205 & 54.7 \\
\hline 312 & 9.98 & 6.17 & 0.209 & 430.0 & 9.55 & 5.25 & 0.204 & 213.9 & & & & \\
\hline 321 & & & & & 12.49 & 5.32 & 0.218 & 304.6 & & & & \\
\hline 330 & 12.90 & 5.35 & 0.209 & 296.5 & 12.47 & 8.57 & 0.182 & 156.3 & 4.81 & 4.40 & 0.210 & 29.2 \\
\hline 341 & 2.93 & 5.06 & 0.164 & 154.9 & 3.73 & 4.90 & 0.205 & 156.2 & 3.64 & 4.20 & 0.195 & 31.1 \\
\hline 352 & 3.76 & 5.33 & 0.215 & 286.9 & 4.07 & 5.29 & 0.185 & 223.1 & & & & \\
\hline 373 & 6.49 & 6.54 & 0.277 & 489.1 & 6.22 & 6.28 & 0.249 & 392.2 & & & & \\
\hline 384 & 6.11 & 7.93 & $\underline{0.321}$ & 715.4 & & & & & & & & \\
\hline 395 & 4.22 & 7.37 & $\underline{0.351}$ & 686.9 & 3.94 & $\underline{34.55}$ & 0.279 & 587.9 & & & & \\
\hline 405 & 4.06 & 6.24 & 0.245 & 564.0 & & & & & 5.41 & 4.19 & 0.223 & 160.6 \\
\hline 415 & 20.33 & 7.00 & 0.185 & 715.1 & & & & & 7.24 & 5.10 & 0.206 & 357.8 \\
\hline 425 & 6.35 & 7.47 & 0.193 & 617.3 & & & & & 14.05 & 3.52 & 0.214 & 249.5 \\
\hline 434 & 5.81 & 5.36 & 0.137 & 508.9 & & & & & 19.24 & 4.47 & 0.215 & 369.0 \\
\hline 453 & 4.49 & 6.85 & 0.131 & 645.6 & & & & & 6.72 & 4.44 & 0.185 & 292.2 \\
\hline 464 & 9.95 & 5.46 & 0.175 & 561.8 & & & & & 7.60 & 4.37 & 0.198 & 371.3 \\
\hline 474 & 8.95 & 5.40 & 0.182 & 435.0 & & & & & 15.84 & 5.29 & 0.231 & 477.9 \\
\hline 484 & 12.27 & 6.48 & 0.161 & 713.2 & & & & & 10.98 & 4.81 & 0.219 & 429.3 \\
\hline \multirow[t]{2}{*}{525} & 6.19 & 4.58 & 0.125 & 469.2 & & & & & 12.47 & 3.33 & 0.178 & 168.0 \\
\hline & & & & & & & & & 15.84 & 4.09 & 0.207 & 310.0 \\
\hline 535 & & & & & & & & & 5.32 & 3.57 & 0.200 & 367.1 \\
\hline 545 & 5.23 & 5.81 & 0.142 & 567.8 & & & & & 15.16 & 3.48 & 0.190 & 380.5 \\
\hline 555 & 2.40 & 5.60 & 0.219 & 534.5 & & & & & 9.08 & 3.88 & 0.190 & 294.0 \\
\hline
\end{tabular}

Composite depths given in $\mathrm{cm}$, after Hagelberg et al. (1995). [Ca] given as $\mathrm{mM}$, and trace metal ratios as $\mu \mathrm{mol} / \mathrm{mol}$. Underlined data are believed to be contaminated, and italicized data are below the [Ca] size cutoff ( $1 \mathrm{mM}$ for $\mathrm{Zn} / \mathrm{Ca}, 2.5 \mathrm{mM}$ for $\mathrm{Cd} / \mathrm{Ca}$ ). 
Table 3.2. New C. wuellerstorfi isotope data from ODP 849

\begin{tabular}{lrrr}
\hline sample & depth $(\mathrm{cm})$ & $\delta^{18} \mathrm{O}(\mathrm{PDB})$ & $\delta^{13} \mathrm{C}(\mathrm{PDB})$ \\
\hline $\mathrm{B}-1 \mathrm{H}-1,31-33 \mathrm{~cm}$ & 32 & 3.15 & 0.16 \\
$\mathrm{~B}-1 \mathrm{H}-1,71-73 \mathrm{~cm}$ & 72 & 4.39 & -0.31 \\
$\mathrm{~B}-1 \mathrm{H}-1,81-83 \mathrm{~cm}$ & 82 & 3.94 & -0.16 \\
$\mathrm{~B}-1 \mathrm{H}-1,91-93 \mathrm{~cm}$ & 92 & 4.11 & -0.09 \\
$\mathrm{~B}-1 \mathrm{H}-1,101-103 \mathrm{~cm}$ & 102 & 4.12 & -0.08 \\
$\mathrm{~B}-1 \mathrm{H}-2,3-5 \mathrm{~cm}$ & 155 & 3.95 & -0.13 \\
$\mathrm{~B}-1 \mathrm{H}-2,73-75 \mathrm{~cm}$ & 227 & 3.71 & -0.04 \\
$\mathrm{~B}-1 \mathrm{H}-2,83-85 \mathrm{~cm}$ & 237 & 4.02 & -0.37 \\
$\mathrm{C}-1 \mathrm{H}-2,3-5 \mathrm{~cm}$ & 312 & 3.48 & -0.09 \\
\hline
\end{tabular}


Table 3.3. Estimates of $\Delta \mathrm{CO}_{3}{ }^{2-}$ and $\left[\mathrm{CO}_{3}{ }^{2-}\right]_{\text {in situ }}$ at ODP 849

\begin{tabular}{|c|c|c|c|c|}
\hline & $\Delta \mathrm{CO}_{3}{ }^{2-}$ & {$\left[\mathrm{CO}_{3}{ }^{2-}\right]$} & $\Delta \mathrm{CO}_{3}{ }^{2-}$ & {$\left[\mathrm{CO}_{3}{ }^{2-}\right]$} \\
\hline \multirow[t]{2}{*}{ modern } & -4 & 88 & -4 & 88 \\
\hline & \multicolumn{2}{|c|}{$\mathrm{Zn} / \mathrm{Ca}$-based } & \multicolumn{2}{|c|}{$\mathrm{Cd} /$ Ca-based } \\
\hline Termination I $(32-52 \mathrm{~cm})$ & $\geq 25$ & $\geq 115-117$ & $\geq 5$ & $\geq 95-97$ \\
\hline LGM $(62-82 \mathrm{~cm})$ & 2 & $92-94$ & -2 & $88-90$ \\
\hline MIS $4(227 \mathrm{~cm})$ & -7 & $83-85$ & -8 & $82-84$ \\
\hline
\end{tabular}

All values given in $\mu \mathrm{mol} / \mathrm{kg}$. $\left[\mathrm{CO}_{3}{ }^{2}\right]_{\text {in situ }}$ ranges are based on the assumption that $\left[\mathrm{CO}_{3}{ }^{2-}\right]_{\text {saturation }}$ has remained within $-2 \mu \mathrm{mol} / \mathrm{kg}$ of the modern value. 
Table 3.4. Carbonate system modeling of ODP 849 data

\begin{tabular}{lrrr} 
& modern & Term. I & LGM \\
\hline alkalinity $\left(\mu \mathrm{mol} \mathrm{kg}^{-1}\right)$ & 2440 & 2536 & 2536 \\
$\Sigma \mathrm{CO}_{2}\left(\mu \mathrm{mol} \mathrm{kg}{ }^{-1}\right)$ & 2332 & 2380 & 2432 \\
$\left.\mathrm{CO}_{3}^{2-}(\mu \mathrm{mol} \mathrm{kg})^{-1}\right)$ & 88 & 117 & 88 \\
$\Delta \mathrm{CO}_{3}^{2-}\left(\mu \mathrm{mol} \mathrm{kg}{ }^{-1}\right)$ & -4 & 25 & -4 \\
$\mathrm{pH}$ & 7.82 & 7.94 & 7.80 \\
\hline
\end{tabular}

Simple one-box (deep ocean) model based on Boyle's (1988b) five-box model. LGM steady state represents the earlier addition of x $\mathrm{\Sigma CO}_{2}$ (vertical rearrangement) and 2y:y Alk: $\Sigma \mathrm{CO}_{2}$ (dissolution response). Termination I transient state represents the removal of x $\Sigma \mathrm{CO}_{2}$ (vertical rearrangement). Modern steady state represents the subsequent removal of $2 \mathrm{y}: \mathrm{y} \mathrm{Alk:}: \mathrm{CO}_{2}$ (preservation response). System is uniquely solved $(\mathrm{x}=52, \mathrm{y}=48$ $\mu \mathrm{mol} \mathrm{kg}^{-1}$ ) to give an LGM $\left[\mathrm{CO}_{3}{ }^{2-}\right]$ equal to the modern (Boyle, 1988a; note that Emerson and Archer [1992] showed that this constraint may not be correct), and a Termination I $\Delta \mathrm{CO}_{3}{ }^{2-}$ of $25 \mu \mathrm{mol} \mathrm{kg}{ }^{-1}$ (as suggested by $\mathrm{Zn} / \mathrm{Ca}$ data). The combined effects of changing sea level, salinity, and temperature are assumed to be negligible, and changes in deep circulation are not accounted for. The potential effect of $\mathrm{NO}_{3}{ }^{-}$on alkalinity is also omitted; although organic matter is generally expected to accompany the $\Sigma \mathrm{CO}_{2}$ rearrangements, it is possible that the two were decoupled (Toggweiler, 1999). In either case, the $\mathrm{NO}_{3}{ }^{-}$effect is small. For comparison, Boyle's (1988b) LGM case G1 used $\mathrm{x}=46$ and $\mathrm{y}=52 \mu \mathrm{mol} \mathrm{kg}{ }^{-1}$ (accounting for $\mathrm{NO}_{3}{ }^{-}$) or $\mathrm{x}=49$ and $\mathrm{y}=49 \mu \mathrm{mol} \mathrm{kg}{ }^{-1}$ (neglecting $\mathrm{NO}_{3}{ }^{-}$) to decrease $p \mathrm{CO}_{2}$ by 46 ppmv. 


\title{
Chapter 4. Depth transects of benthic foraminiferal $\mathrm{Zn} / \mathrm{Ca}$ and $\mathrm{Cd} / \mathrm{Ca}$ in the North Atlantic: deep water reorganization during the last glacial maximum
}

\begin{abstract}
Benthic foraminiferal $\delta^{13} \mathrm{C}$ and $\mathrm{Cd} / \mathrm{Ca}$ studies suggest that deep Atlantic circulation during the last glacial maximum was very different from today, with highnutrient (low- $\delta^{13} \mathrm{C}$, high-Cd) deep Southern Ocean Water (SOW) penetrating far into the North Atlantic. However, if some glacial $\delta^{13} \mathrm{C}$ values are biased by productivity artifacts and/or air-sea exchange processes, then the existing data may be consistent with the continual formation of North Atlantic Deep Water (NADW). Cd/Ca results presented here suggest that the glacial North Atlantic was strongly enriched in dissolved Cd below $\sim 2500 \mathrm{~m}$ depth. These data could, in theory, be explained by increased preformed nutrient levels in the high-latitude North Atlantic or by increased aging of lower NADW. High glacial $\mathrm{Zn} / \mathrm{Ca}$ values in the same samples, however, require a substantially increased mixing with SOW and thus a reduction in NADW formation. This rearrangement of deep Atlantic circulation also lowered in situ $\mathrm{CO}_{3}{ }^{2-}$ concentrations by perhaps 10 to $20 \mu \mathrm{mol} \mathrm{kg}{ }^{-1}$.
\end{abstract}

\section{Introduction}

It has long been suggested that the formation of North Atlantic Deep Water (NADW) was curtailed during glacial periods (e.g., Weyl, 1968; Newell, 1974; Duplessy et al., 1975). Curry and Lohmann (1982) used benthic foraminifera to reconstruct a last glacial maximum (LGM) bathymetric profile of $\delta^{13} \mathrm{C}$ in the Vema Channel (western South Atlantic). They argued that their data indicated a shoaling of the boundary between northern and southern source deep waters, and speculated that this geometry could have resulted from a reduction or cessation of NADW production. Boyle and Keigwin (1982) showed that deep North Atlantic benthic foraminiferal $\mathrm{Cd} / \mathrm{Ca}$ ratios, and thus seawater dissolved $\mathrm{Cd}$ concentrations, were higher during glacial periods. This suggested that the flux of nutrient-depleted NADW was indeed reduced relative to that of nutrient-rich southern source waters, though never completely ceased. Together these studies implied that deep Southern Ocean Water (SOW, equivalent to Antarctic Bottom Water [AABW] and/or Circumpolar Deep Water [CPDW]) was able to penetrate farther northward into the Atlantic during the LGM. 
As spatial data coverage within the Atlantic increased, a more detailed picture of inferred LGM circulation emerged. Increased $\delta^{13} \mathrm{C}$ and low $\mathrm{Cd} / \mathrm{Ca}$ values in intermediate depth waters (above $\sim 2000 \mathrm{~m}$ ) signaled the presence of a nutrient-depleted water mass (Oppo and Fairbanks, 1987; Boyle and Keigwin, 1987). Boyle and Keigwin (1987) argued that surface conditions in the glacial North Atlantic (colder and less saline) favored the production of intermediate waters rather than NADW. The extent of this water mass, dubbed Glacial North Atlantic Intermediate Water (GNAIW), was mapped in some detail by Duplessy et al. (1988) using $\delta^{13} \mathrm{C}$. Additional $\delta^{13} \mathrm{C}$ studies have further refined this view (e.g., Oppo and Lehman, 1993; Sarnthein et al., 1994). LGM Cd/Ca data agree with $\delta^{13} \mathrm{C}$ on a gross scale, but differ in two important ways (Boyle, 1992; Boyle and Rosenthal, 1996). First, $\delta^{13} \mathrm{C}$ implies that North Atlantic intermediate waters were greatly depleted in nutrients relative to today, while $\mathrm{Cd} / \mathrm{Ca}$ suggests a much smaller decrease; the main $\mathrm{Cd} / \mathrm{Ca}$ change appears to be limited to deeper waters (note, however, that intermediate-depth $\mathrm{Cd} / \mathrm{Ca}$ and $\delta^{13} \mathrm{C}$ do imply similar nutrient depletions in some regions, such as the Bahama Banks [Marchitto et al., 1998]). Second, $\delta^{13} \mathrm{C}$ implies that Antarctic deep waters were greatly enriched in nutrients relative to today, while $\mathrm{Cd} / \mathrm{Ca}$ again suggests little change. Boyle and Rosenthal (1996) concluded that the latter discrepancy is mainly due to a $\delta^{13} \mathrm{C}$ artifact that occurs beneath regions of high surface water productivity (Mackensen et al., 1993).

The hypothesis of NADW replacement by GNAIW and SOW assumes that surface water ("preformed") nutrient levels in the glacial North Atlantic were not significantly different than today. Mix and Fairbanks (1985) noted the similarity between planktonic and benthic $\delta^{13} \mathrm{C}$ records in the North Atlantic, and proposed that at least some of the glacial $\delta^{13} \mathrm{C}$ depletion in the deep Atlantic could be explained by lower preformed values due to higher initial nutrient contents. They further speculated that if glacial NADW formed beneath sea and shelf ice, then the combination of increased preformed nutrients and reduced air-sea isotopic exchange might explain the entire deep Atlantic $\delta^{13} \mathrm{C}$ decrease. The planktonic foraminifer used by Mix and Fairbanks (1985) (Neogloboquadrina pachyderma [s.]) has since been shown to be a poor recorder of 
seawater $\delta^{13} \mathrm{C}$, however, and planktonic $\mathrm{Cd} / \mathrm{Ca}$ shows no apparent glacial increase in the North Atlantic (Keigwin and Boyle, 1989). Nevertheless, remaining uncertainties in the end member compositions of glacial northern and southern source waters make volumetric deep water reconstructions somewhat ambiguous (LeGrand and Wunsch, 1995).

The idea of persistent NADW formation during the LGM was recently revived by Matsumoto and Lynch-Stieglitz (1999). They proposed that many Southern Ocean benthic $\delta^{13} \mathrm{C}$ data are affected by Mackensen et al.'s (1993) productivity artifact, and estimated that the "true" LGM Southern Ocean value must be close to $-0.2 \%$. Thus LGM deep ocean $\delta^{13} \mathrm{C}(>2500 \mathrm{~m})$ decreased from north to south in the Atlantic and from south to north in the Pacific, as it does today. In addition, the LGM "whole ocean" gradient $(\sim 1.1 \%$ ) was the same as today, although more aging appears to have occurred within the Atlantic and less within the Pacific. The authors concluded that NADW circulation was not significantly different from the modern, and that SOW did not penetrate farther north than it does today. They did not rule out the presence of GNAIW, but proposed that the vertical gradient in glacial $\delta^{13} \mathrm{C}$ was mainly caused by differences in preformed values, largely due to latitudinal gradients in North Atlantic air-sea exchange (Lynch-Stieglitz and Fairbanks, 1994). Although Matsumoto and Lynch-Stieglitz's (1999) observations are also consistent with a mixing between reduced-volume NADW and northwardpenetrating SOW, their circulation scheme cannot be ruled out using $\delta^{13} \mathrm{C}$ alone.

Under Matsumoto and Lynch-Stieglitz's (1999) scenario, deep LGM Cd/Ca data (Boyle, 1992) require that either high-latitude North Atlantic preformed nutrients were higher, or that lower NADW collected more remineralized nutrients over a given distance than it does today. An increase in preformed [Cd] is in apparent contradiction with planktonic $\mathrm{Cd} / \mathrm{Ca}$ data (Keigwin and Boyle, 1989). However, it has recently been suggested that planktonic foraminiferal $\mathrm{Cd} / \mathrm{Ca}$ decreases with temperature (Rickaby and Elderfield, 1999), so glacial North Atlantic data may underestimate surface water Cd concentrations. An increase in nutrient accumulation independent of mixing (i.e., "aging"), which could occur by increased particulate rain rates or by more sluggish 
circulation, is difficult to rule out using published data. It would only require that GNAIW formation was much more rapid than the southward progression of deeper waters, a situation that is supported by sedimentological current speed evidence (e.g., Ledbetter and Balsam, 1985; Haskell et al., 1991; McCave et al., 1995).

The ambiguity surrounding SOW penetration into the North Atlantic can be resolved using benthic foraminiferal $\mathrm{Zn} / \mathrm{Ca}$. In the modern ocean, both dissolved $\mathrm{Cd}$ and dissolved $\mathrm{Zn}$ are completely removed from most surface waters, but $\mathrm{Zn}$ has a deeper regeneration cycle (e.g., Bruland et al., 1978; Bruland and Franks, 1983; Boyle, 1988). While $\mathrm{AABW}$-like $\mathrm{Cd}$ concentrations (estimated from $\mathrm{P}$ ) are found in intermediate waters as far north as $15^{\circ}$ in the western North Atlantic, AABW-like $\mathrm{Zn}$ concentrations (estimated from $\mathrm{Si}$ ) are limited to deep Southern Ocean waters (Figure 4.1). Thus any increase in deep water [Cd] caused by higher North Atlantic preformed nutrients or greater aging would be accompanied by a comparatively small increase in deep water $[\mathrm{Zn}]$. The only way to produce high $\mathrm{Zn}$ concentrations would be by mixing with SOW.

\section{Study area and previous work}

The nine sediment cores used in this study are confined to the North Atlantic above $40^{\circ} \mathrm{N}$ and span a depth range of 1326 to $3427 \mathrm{~m}$ (Figure 4.2, Table 4.1; for simplicity, no correction for lowered sea level will be made to the LGM depths). Four of the cores, including the three deepest, are from the western flank of the Mid-Atlantic Ridge between $\sim 42^{\circ} \mathrm{N}$ and $44^{\circ} \mathrm{N}$. The other five cores are from the northeast North Atlantic between $\sim 55^{\circ} \mathrm{N}$ and $61^{\circ} \mathrm{N}$. Today all of the sites are bathed by nearly pure NADW, as can be seen using a $\theta-\mathrm{S}$ diagram (Figure 4.3) (note that "pure NADW" is used as a generic term to describe deep waters originating in the north, before any significant mixing with deep or intermediate waters from the south; it is close to, but not necessarily identical to, Broecker and Peng's [1982] Northern Component Water [NCW]). There is a slight increase in dissolved nutrients between the northeastern and Mid-Atlantic Ridge regions, with $\mathrm{P}$ increasing by roughly $0.1 \mu \mathrm{mol} \mathrm{kg}{ }^{-1}\left(\sim 0.02 \mathrm{nmol} \mathrm{kg}{ }^{-1} \mathrm{Cd}\right)$ and $\mathrm{Si}$

increasing by roughly $3 \mu$ mol $\mathrm{kg}^{-1}(\sim 0.2$ nmol kg-1 $\mathrm{Zn})$ (Bainbridge, 1981). These 
gradients are small compared to the scatter typical of foraminiferal data, and the nine cores will be treated together in this study. $\Delta \mathrm{CO}_{3}{ }^{2-}$ estimates calculated from nearest GEOSECS data (Bainbridge, 1981) range from $\sim 23$ to $45 \mu \mathrm{mol} \mathrm{kg}^{-1}$ (see Appendix 2 for equations). Although the low end of the range corresponds to a very slight effect on $\mathrm{Zn}$ partition coefficients (Chapter 2), no correction will be made to the Holocene $\mathrm{Zn} / \mathrm{Ca}$ data.

Cibicidoides $\delta^{13} \mathrm{C}$ has been previously measured in the late Holocene and LGM sections of each core (Boyle and Keigwin, 1982, 1985/6, 1987; Boyle, 1992; Oppo and Lehman, 1993, 1995; McManus et al., 1999; Curry et al., in press) (Figure 4.4a, Table 4.2). Holocene data are relatively uniform with depth $(1.14 \pm 0.11 \%$ ), as expected from the water column measurements of Kroopnick (1985). LGM data are enriched (relative to the Holocene) by up to $0.23 \%$ above $\sim 2000 \mathrm{~m}$ and depleted by up to $0.63 \%$ below this depth. The exception is CHN82-15PC at $2153 \mathrm{~m}$ and $43^{\circ} \mathrm{N}$, which has a glacial enrichment of $0.23 \%$; this may reflect a slight deepening of the base of GNAIW with decreasing latitude. Benthic foraminiferal $\mathrm{Cd} / \mathrm{Ca}$ has also been measured in the four CHN82 cores (Boyle and Keigwin, 1982, 1985/6, 1987; Boyle, 1992) (Table 4.2). Figure $4.4 \mathrm{~b}$ shows these data after conversion to inferred seawater $\mathrm{Cd}$ concentration $\left(\mathrm{Cd}_{\mathrm{W}}\right)$ using the depth-dependent partition coefficients of Boyle (1992). Again, Holocene data are relatively uniform with depth $\left(0.22 \pm 0.03 \mathrm{nmol} \mathrm{kg}^{-1}\right)$, as predicted from seawater dissolved P concentrations (Bainbridge, 1981). LGM data below $3000 \mathrm{~m}$ are higher than

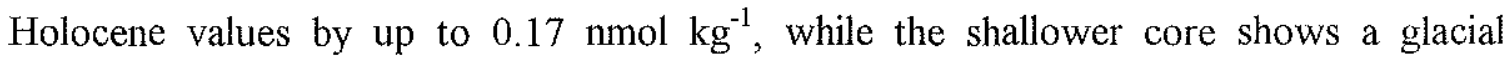
depletion of $0.05 \mathrm{nmol} \mathrm{kg}{ }^{-1}$.

$\delta^{13} \mathrm{C}$ and $\mathrm{Cd}$ wata can be compared more directly by converting each to equivalent $\mathrm{P}$. The modern relationship between $\delta^{13} \mathrm{C}$ and $\mathrm{P}$ is based on the data of Broecker and Maier-Reimer (1992) as reformulated by Lynch-Stieglitz and Fairbanks (1994):

$$
[\mathrm{P}]=2.45-\left(0.91\left[\delta^{13} \mathrm{C}-\delta^{13} \mathrm{C}_{\mathrm{as}}\right]\right)
$$

where $\delta^{13} \mathrm{C}_{\mathrm{as}}$ is the air-sea exchange component of $\delta^{13} \mathrm{C}$ (i.e., the deviation from the "biological" relationship to P). During the LGM, organic matter $\delta^{13} \mathrm{C}$ was $\sim 2 \%$ higher 
(Rau et al., 1991) and mean ocean $\delta^{13} \mathrm{C}$ was $\sim 0.3 \%$ lower (Duplessy et al., 1988), so the relationship between $\delta^{13} \mathrm{C}$ and $\mathrm{P}$ was slightly different (Lynch-Stieglitz et al., 1996):

$$
[\mathrm{P}]=2.16-\left(1.05\left[\delta^{13} \mathrm{C}-\delta^{13} \mathrm{C}_{\mathrm{as}}\right]\right)
$$

The Cd:P relationship is after Boyle (1988):

$$
\begin{aligned}
& {[\mathrm{P}]=4.81 \mathrm{Cd}_{\mathrm{W}}\left(\text { for } \mathrm{Cd}_{\mathrm{W}}<0.28 \mathrm{nmol} \mathrm{kg}{ }^{-1}\right)} \\
& {[\mathrm{P}]=0.638+2.51 \mathrm{Cd}_{\mathrm{W}}\left(\text { for } \mathrm{Cd}_{\mathrm{W}}>0.28 \mathrm{nmol} \mathrm{kg}^{-1}\right)}
\end{aligned}
$$

Although it has been suggested that the LGM ocean contained perhaps $13 \%$ less dissolved $\mathrm{Cd}$ than today, this decrease is not well enough constrained to warrant the use of different equations for the glacial Cd $\mathrm{W}_{\mathrm{W}}$ data (Boyle, 1992; Lynch-Stieglitz et al., 1996).

$\delta^{13} \mathrm{C}$-derived $\mathrm{P}$ estimates for the Holocene, calculated using the modern North Atlantic $\delta^{13} \mathrm{C}_{\text {as }}$ values given by Lynch-Stieglitz and Fairbanks (1994), agree well with seawater $\mathrm{P}$ measurements (Figure 4.5a). Assuming that $\delta^{13} \mathrm{C}_{\mathrm{as}}$ was the same during the LGM, $\delta^{13} \mathrm{C}$ suggests that $\mathrm{P}$ concentrations were similar to or slightly higher than today below $\sim 2500 \mathrm{~m}$ but significantly lower than today, by as much as $0.8 \mu \mathrm{mol} \mathrm{kg}{ }^{-1}(80 \%)$, above $\sim 2500 \mathrm{~m}$. Cd, on the other hand, suggests a $[\mathrm{P}]$ increase of up to $0.6 \mu \mathrm{mol} \mathrm{\textrm {kg } ^ { - 1 }}$ below $3000 \mathrm{~m}$ and a relatively small decrease $\left(0.2 \mu \mathrm{mol} \mathrm{kg}{ }^{-1}\right)$ at $2153 \mathrm{~m}$ (Figure $4.5 \mathrm{~b}$ ). The two tracers can be made to agree reasonably well by assuming that $\delta^{13} \mathrm{C}_{\text {as }}$ was $\sim 0.3 \%$ o higher than today during the LGM (crosses in Figure 4.5a). The subject of LGM $\delta^{13} \mathrm{C}_{\mathrm{as}}$ will be discussed in further detail below.

\section{Materials and methods}

Late Holocene and LGM intervals of each sediment core were identified using previously generated stable isotope data (Boyle and Keigwin, 1982, 1985/6, 1987; Boyle, 1992; Oppo and Lehman, 1993, 1995; McManus et al., 1999; Curry et al., in press). Zn, $\mathrm{Cd}$, and $\mathrm{Mn}$ concentrations were measured in shells of the benthic foraminifera $C$. wuellerstorfi, C. kullenbergi (includes C. pachyderma), and Uvigerina spp. Each sample consisted of $\sim 5$ to 15 individuals $(>250 \mu \mathrm{m})$, and was cleaned following the methods of Boyle and Keigwin (1985/6) as modified by Rosenthal (1994) and Boyle and Rosenthal (1996). Additional precautions were taken to minimize the risk of laboratory 
contamination, which has historically been a major obstacle to $\mathrm{Zn}$ work (Bruland et al., 1978). $\mathrm{Zn}, \mathrm{Cd}$, and $\mathrm{Mn}$ were measured sequentially by graphite furnace atomic absorption spectrophotometry (AAS) and $\mathrm{Ca}$ was measured by flame AAS, all on a Hitachi Z-8200. Analytical precision, based on frequent analyses of three consistency standards, is $\pm 2-3 \%$ for $\mathrm{Zn}, \pm 3-6 \%$ for $\mathrm{Cd}, \pm 8-9 \%$ for $\mathrm{Mn}$, and $\pm 1 \%$ for $\mathrm{Ca}$ (see Appendix 1 for further details on analytical methods and precision).

\section{Results and discussion}

\section{Cd/Ca profiles}

Holocene and LGM Cd/Ca values measured in each core are shown in Figure 4.6a and listed in Table 4.3. For comparison, previously published $\mathrm{Cd} / \mathrm{Ca}$ data from above $40^{\circ} \mathrm{N}$ in the North Atlantic are shown in Figure 4.6b (Boyle and Keigwin, 1982, 1985/6, 1987; Boyle, 1992; Bertram et al., 1995). The two data sets agree in that LGM values are lower than Holocene above $\sim 2500 \mathrm{~m}$ and higher than Holocene below this depth. The only exception is core V29-204 at $1849 \mathrm{~m}$, whose Holocene sample was small and contained virtually no measurable $\mathrm{Cd}$; the error on this sample should be considered to be large, but the "true" value is probably no higher than $\sim 0.05 \mu \mathrm{mol} \mathrm{mol}{ }^{-1}$ (otherwise there would have been a measurable $\mathrm{Cd}$ peak). All but three $\mathrm{Mn} / \mathrm{Ca}$ data are below $75 \mu \mathrm{mol}$ $\mathrm{mol}^{-1}$ (Table 4.3), suggesting that Mn-carbonate overgrowths are not a major source of contamination.

New $C$. wuellerstorfi $\mathrm{Cd} / \mathrm{Ca}$ values are significantly higher than coexisting $C$. kullenbergi and Uvigerina values in the three deepest cores. Such large offsets are not unusual in deep sea cores and may reflect, in part, the mixing together on noncontemporaneous individuals (Boyle, 1992; Boyle, 1995). Boyle reported C. wuellerstorfi data from only one of these cores, CHN82-20 (3070 m; Boyle and Keigwin, 1985/6). He found no consistent offset between $C$. wuellerstorfi and the other two taxa, but there is a large amount of variability in the data. For example, within the LGM section identified by Boyle and Keigwin $(1985 / 6)$, C. wuellerstorfi values decrease from a high of $>0.12$ $\mu \mathrm{mol} \mathrm{mol}{ }^{-1}\left(\sim 80 \mathrm{~cm}\right.$ depth) to a low of $<0.08 \mu \mathrm{mol} \mathrm{mol}^{-1}(\sim 75 \mathrm{~cm})$ (my measured value is 
$0.125 \mu \mathrm{mol} \mathrm{mol} \mathrm{m}^{-1}$ at $80-82 \mathrm{~cm}$ ). A species-by-species comparison of my data with Boyle's does not suggest any significant analytical offset (Figure 4.7). I will therefore assume that my deep C. wuellerstorfi data reflect true bottom water conditions, possibly during circulation extremes. Heinrich events 1 and 2 could be mixed into some of these data, though this is not the case for CHN82-20, the only one of the deep cores where Heinrich event 1 has been clearly identified (Keigwin and Lehman, 1994). Glacial values above $0.15 \mu \mathrm{mol} \mathrm{mol}^{-1}$ occur elsewhere in the North Atlantic, such as in Bermuda Rise core EN120-GGC1 (4450 m) which reached $0.22 \mu \mathrm{mol} \mathrm{mol}^{-1}$ (Boyle and Keigwin, 1987).

The ensuing discussion will focus on C. wuellerstorfi for two reasons. First, it is the only species present in both Holocene and LGM sections from all water depths (the exception being the Holocene of ODP 980, where none of the three taxa were available). This is especially important for $\mathrm{Zn} / \mathrm{Ca}$ because the partition coefficient for C. kullenbergi is not known (Chapter 2), making direct comparisons to other species impossible. Second, there is some indication that Uvigerina responds differently to $\Delta \mathrm{CO}_{3}{ }^{2-}$ than $C$. wuellerstorfi does (Chapter 3), perhaps due to its infaunal habitat (Zahn et al., 1986). Although bottom water $\Delta \mathrm{CO}_{3}{ }^{2-}$ is probably an issue for $\mathrm{LGM} \mathrm{Zn} / \mathrm{Ca}$ only, pore water $\Delta \mathrm{CO}_{3}{ }^{2-}$ may be low enough (e.g., Martin and Sayles, 1996) to affect Uvigerina $\mathrm{Cd} / \mathrm{Ca}$.

Holocene and $\mathrm{LGM}$ profiles of $\mathrm{Cd}_{\mathrm{W}}$, converted from C. wuellerstorfi $\mathrm{Cd} / \mathrm{Ca}$ using the depth-dependent partition coefficients of Boyle (1992), are shown in Figure 4.8. Most of the Holocene data are slightly higher than predicted from modern dissolved $\mathrm{P}$ estimates (Bainbridge, 1981). Two of the shallow Holocene data (V29-193 at $1326 \mathrm{~m}$ and V28-73 at $2063 \mathrm{~m}$ ) are much higher than expected, a problem noted by Bertram et al. (1995) in several cores from the same region (northeast North Atlantic above $50^{\circ} \mathrm{N}$ ). They concluded that regional partition coefficients are elevated for some unspecified reason. However, two of my other cores from this area (V29-202 and V29-204) do not share this pattern. I suggest that the tops of V28-73, V29-193, and Bertram et al.'s (1995) cores are contaminated. This contamination may be prevalent in the northeast North Atlantic, but it is clearly not ubiquitous. LGM data from the cores with elevated 
Holocene values appear to agree well with other LGM data (Figures 4.6, 4.8), suggesting that the contamination is limited to the upper sections of these cores.

LGM Cd $\mathrm{W}_{\mathrm{W}}$ data above $\sim 2500 \mathrm{~m}$ are similar to modern predicted values, while deeper data are significantly enriched in $\mathrm{Cd}$. This is essentially the same pattern observed by Boyle (1992), but with a greater deep enrichment. The deep values are close to those observed in LGM C. whellerstorfi from the low-latitude eastern North Atlantic below $\sim 3500 \mathrm{~m}\left(0.52-0.54 \mathrm{nmol} \mathrm{kg}^{-1}\right.$ ) (Boyle, 1992; Beveridge et al., 1995). The difference between LGM and Holocene values increases with depth, from $0.07 \mathrm{nmol} \mathrm{kg}^{-1}$ at $2658 \mathrm{~m}$ to $0.27 \mathrm{nmol} \mathrm{kg}^{-1}$ at 3427 . Differences from modern predicted values increase from $\sim 0.17$ to $0.37 \mathrm{nmol} \mathrm{kg}$. In theory, these deep glacial values could be reached through three mechanisms: (1) increased preformed nutrient concentrations in the high-latitude North Atlantic; (2) greater addition of remineralized organic matter to lower NADW (aging); and/or (3) decreased flux of NADW and increased mixing with SOW. Each of these scenarios will be modeled to give predicted $\mathrm{Zn} / \mathrm{Ca}$ values, which will then be compared to actual measurements.

\section{Three glacial circulation models}

Before attempting to infer LGM deep circulation, it is necessary to adopt a simple nutrient model that works for the modern ocean. I assume that deep water nutrient concentrations change by two mechanisms: remineralization of biological rain (aging) and mixing with other water masses. Because of the kink in the modern seawater $\mathrm{Cd}: \mathrm{P}$ relationship (Boyle, 1988), Cd-based and P-based estimates of mixing proportions are slightly different. Here, aging and mixing will both be modeled using $\mathrm{P}$ (which is much better understood in the modern ocean), and it will be assumed that Cd follows along "passively", i.e., P estimates will be converted to Cd using Boyle's (1988) equations. The modern $\mathrm{Zn}: \mathrm{Si}$ relationship is also kinked at low concentrations in the North Atlantic (Figure 4.9), so aging and mixing will be modeled using $\mathrm{Si}$ and then converted to $\mathrm{Zn}$, again assuming a passive coupling. Counter-intuitively, the resulting $\mathrm{Cd}$ and $\mathrm{Zn}$ estimates do not require that glacial $\mathbf{P}$ and $\mathrm{Si}$ oceanic inventories were the same as today. They only 
require that $\mathrm{Cd}$ and $\mathrm{Zn}$ inventories were relatively unchanged, and that $\mathrm{Cd}$ and $\mathrm{Zn}$ were regenerated in manners similar to today. In other words, "P" can be thought of as a convenient way of handling $\mathrm{Cd}$ data; by incorporating the kink, it essentially simulates the $\mathrm{Cd}$ regeneration process. All calculations in the text will use the data from core CHN82-20PC (3070 m) as an example; results from the other three deepest cores are listed in Table 4.4 .

The aging process within the North Atlantic can be examined by following modern $\mathrm{P}$ and Si from the region of NADW formation in the Greenland Sea through the core of NADW (Figure 4.10). By a depth of about $50 \mathrm{~m}$ in the Greenland Sea, P and Si begin to fall along a linear aging trend that continues well into the open North Atlantic. The minimum values along this trend are chosen to represent preformed NADW $(\sim 0.70$ $\mu \mathrm{mol} \mathrm{kg} \mathrm{kg}^{-1}$ for $\mathrm{P}$ and $4.0 \mu \mathrm{mol} \mathrm{kg}{ }^{-1}$ for $\mathrm{Si}$; note that two to three significant digits will be used for calculations, but I make no claim that the various parameters are known to such high precision). The preformed $\mathbf{P}$ value is the same as Broecker and Peng's (1982) choice for preformed NCW. The slope of this line characterizes remineralization within pure NADW, with a Si:P addition ratio of about 21:1.

Mixing at CHN82-20PC is modeled as the simple combination of two endmembers, NADW and SOW (AABW today), both of which are aged beyond their preformed values prior to mixing. This model does not attempt to deal with the effects of diffusion and diapycnal mixing. It is difficult to choose an appropriate aged SOW endmember because SOW aging is strongly masked by mixing with NADW in the modern ocean. I choose the maximum $\mathrm{P}$ and $\mathrm{Si}$ concentrations found in the Atlantic before dilution with NADW $\left(\sim 2.32\right.$ and $130 \mu \mathrm{mol} \mathrm{kg}{ }^{-1}$, respectively, at $\sim 45^{\circ} \mathrm{S},>5500 \mathrm{~m}$ ) (Figure 4.10). These values are slightly aged relative to Broecker et al.'s (1991) Southern Component Water $\left(\mathrm{SCW} \sim 2.19,120 \mu \mathrm{mol} \mathrm{kg}{ }^{-1}\right.$ ). The high apparent $\mathrm{Si}: \mathrm{P}$ aging ratio within the Southern Ocean (relative to the North Atlantic) is due to high rates of siliceous productivity. Once SOW leaves this region, its aging slope should decrease, but the character of this decrease is unknown. Therefore any additional aging during the northward progression of glacial SOW cannot be easily modeled. However, because the 
two end-members have such disparate nutrient contents relative to the likely magnitude of unaccounted-for aging, the resulting error should be small.

A larger potential error surrounds the initial composition of glacial SOW before it leaves the Southern Ocean. LGM Southern Ocean $\delta^{13} \mathrm{C}$ values, even after discarding cores suspected of being biased by productivity artifacts, were about $0.5 \%$ to $0.8 \%$ lower than today (Matsumoto and Lynch-Stieglitz, 1999), implying a significant nutrient increase. Some of this change must be due to decreased mixing with low-nutrient NADW, but some of it could also be due to higher preformed nutrient values in SOW. Although Southern Ocean $\mathrm{Cd} / \mathrm{Ca}$ data suggest no significant difference from today (Boyle, 1992; Boyle and Rosenthal, 1996), it is possible that some of these values are reduced by a $\Delta \mathrm{CO}_{3}{ }^{2-}$ artifact (McCorkle et al., 1995). For the sake of simplicity, however, I assume that the preformed nutrient content of SOW was the same as today. In summary, while NADW preformed values and degree of aging will both be allowed to vary, the SOW end-member will be held constant at the "aged SOW" coordinates (Figure 4.10).

The modern aged NADW end-member is determined by extrapolating the mixing line between aged SOW and CHN82-20PC to the NADW aging line (Figure 4.10). This gives a $\mathrm{P}$ concentration of $\sim 1.13 \mu \mathrm{mol} \mathrm{kg} \mathrm{kg}^{-1}$ and a Si concentration of $\sim 12.7 \mu \mathrm{mol} \mathrm{kg}{ }^{-1}$, very slightly aged relative to Broecker et al.'s (1991) NCW $\left(\sim 1.08,12 \mu \mathrm{mol} \mathrm{kg}{ }^{-1}\right)$. By this scheme, modern waters at CHN82-20PC are about 5\% SOW. This is similar to Broecker et al.'s (1991) estimate based on the conservative tracer $\mathrm{PO}_{4}{ }^{*}$, which puts the region of CHN82-20PC about mid-way between the $0 \%$ and $10 \% \mathrm{SCW}$ contours.

To model the first LGM scenario, increased preformed nutrients, NADW aging is held constant ( $\mathrm{P}$ increase of $0.43 \mu \mathrm{mol} \mathrm{kg}{ }^{-1}$ over the unspecified preformed value) and mixing with SOW is held constant $(4.5 \% \mathrm{SOW})$. These constraints require a preformed $\mathrm{P}$ concentration of $1.27 \mu \mathrm{mol} \mathrm{kg}^{-1}\left(\mathrm{Cd}=0.26 \mathrm{nmol} \mathrm{kg}^{-1}\right)$, almost double the modern value, to yield a CHN82-20PC concentration of $1.72 \mu \mathrm{mol} \mathrm{\textrm {kg } ^ { - 1 }}$ (based on $0.43 \mathrm{nmol} \mathrm{kg}^{-1} \mathrm{Cd}_{\mathrm{W}}$ ) (Table 4.4). Algebraically:

$$
0.955(p+0.43)+0.045(2.32)=1.72
$$


where 0.955 and 0.045 are the proportions of NADW and SOW, $p$ is the NADW preformed $\mathrm{P}$ concentration, 0.43 is the aging component, and 2.32 is the SOW P concentration. The only logical source for such elevated preformed NADW nutrients (aside from upwelled deep SOW) is mid-latitude intermediate waters, where $\mathbf{P}$ concentrations of $1.35 \mu \mathrm{mol} \mathrm{kg}{ }^{-1}$ are found as far north as $45^{\circ} \mathrm{N}$ today (Bainbridge, 1981) (see Figure 4.1 for $\mathrm{Cd}$ ). This general region also supplies the "feed water" for modern NADW (Broecker and Peng, 1982). However, the available LGM Cd/Ca data from the mid to low-latitude North Atlantic suggest that intermediate and shallow waters were depleted in nutrients relative to today (Boyle, 1992; Marchitto et al., 1998). Also, surface waters near $55^{\circ} \mathrm{N}$ to $65^{\circ} \mathrm{N}$ must have remained low in nutrients because high-latitude cores shallower than $\sim 2500 \mathrm{~m}$ do not show any glacial enrichment (Boyle, 1992; Figure 4.8). It is therefore difficult to imagine how such high $\mathrm{P}$ and $\mathrm{Cd}$ concentrations could have extended to the shallow, high latitude North Atlantic without impacting lower latitudes. The eastern basin is a possible route, though $\mathrm{Cd} / \mathrm{Ca}$ data from the Portuguese margin near $1000 \mathrm{~m}$ depth suggest that nutrient contents were elevated only during Heinrich events (Williamowski and Zahn, 1998).

Regardless of the hypothetical route, concomitant preformed NADW Si and Zn increases can be estimated by looking to P:Si ratios in the presumed source (mid-latitude intermediate waters). A P concentration of $1.27 \mu \mathrm{mol} \mathrm{kg}^{-1}$ is expected to be accompanied by a Si concentration of only $\sim 12.5 \mu \mathrm{mol} \mathrm{kg}{ }^{-1}\left(\mathrm{Zn}=1.4 \mathrm{nmol} \mathrm{kg}{ }^{-1}\right)$. By again assuming constant NADW aging ( $\mathrm{Si}$ increase of $8.7 \mu \mathrm{mol} \mathrm{kg}{ }^{-1}$ over the preformed value) and constant mixing (4.5\% SOW), the resulting LGM Si concentration at CHN82-20PC can be predicted:

$$
0.955(12.5+8.7)+0.045(130)=\mathrm{c}
$$

where $\mathrm{c}$ is the CHN82-20PC Si concentration, equal to $26.1 \mu \mathrm{mol} \mathrm{kg}{ }^{-1}(\mathrm{Zn}=2.1 \mathrm{nmol}$ $\left.\mathrm{kg}^{-1}\right)$. Thus the maximum $\left(D_{\mathrm{Zn}}=9\right) \mathrm{LGM} \mathrm{Zn} / \mathrm{Ca}$ value predicted by this circulation scenario is $1.9 \mu \mathrm{mol} \mathrm{mol}^{11}$.

For the second LGM scenario, increased NADW aging, preformed nutrients are held constant $\left(\mathbf{P}=0.70 \mu \mathrm{mol} \mathrm{kg}{ }^{-1}\right)$ and mixing with SOW is again held constant. The 
amount of $\mathrm{P}$ addition from remineralization within the North Atlantic (aging) required to reach the LGM concentration at CHN82-20PC is therefore $0.99 \mu \mathrm{mol} \mathrm{kg}{ }^{-1}$, more than double the modern estimate:

$$
0.955(0.70+a)+0.045(2.32)=1.72
$$

where $\mathrm{a}$ is the aging component. Assuming that $\mathrm{Si}$ was added along with $\mathrm{P}$ in the same ratio as today (i.e., extending the NADW aging line in Figure 4.10), this suggests that $\mathrm{Si}$ increased by $\sim 20.4 \mu \mathrm{mol} \mathrm{kg}{ }^{-1}$, giving a CHN82-20PC concentration of $29.2 \mu \mathrm{mol} \mathrm{kg}{ }^{-1}$ $\left(\mathrm{Zn}=2.3 \mathrm{nmol} \mathrm{kg}^{-1}\right)$ :

$$
0.955(4.0+20.4)+0.045(130)=\mathrm{c}
$$

This circulation scheme therefore predicts that LGM Zn/Ca at CHN82-20PC should be no higher than $2.1 \mu \mathrm{mol} \mathrm{mol}^{-1}$ (for $D_{\mathrm{Zn}}=9$ ), similar to the estimate from the first model.

The final circulation scenario, reduced NADW formation and increased mixing with SOW, has the potential to result in significantly higher $\mathrm{Zn}$ concentrations at CHN8220PC. This is because deep SOW contains much more Si and $\mathrm{Zn}$ than North Atlantic intermediate and surface waters, which were the sources of increased nutrients in the first two schemes. For the increased mixing model, preformed nutrients and NADW aging are both held constant. These constraints require a $50 \%$ contribution from SOW to give the LGM P concentration at CHN82-20PC:

$$
(1-\mathrm{s})(0.70+0.43)+\mathrm{s}(2.32)=1.72
$$

where $\mathrm{s}$ is the proportion of SOW. This dramatic SOW increase predicts a CHN82-20PC Si concentration of $\sim 71.1 \mu \mathrm{mol} \mathrm{kg}{ }^{-1}\left(\mathrm{Zn}=4.5 \mathrm{nmol} \mathrm{kg}^{-1}\right)$ :

$$
0.503(4.0+8.7)+0.497(130)=\mathrm{c}
$$

The resulting maximum $\mathrm{Zn} / \mathrm{Ca}$ value is therefore $4.0 \mu \mathrm{mol} \mathrm{mol}^{-1}$, almost double the previous two predictions. However, the increased influence of low- $\mathrm{CO}_{3}{ }^{2-} \mathrm{SOW}$ would be expected to reduce this number somewhat. The modern $\mathrm{CO}_{3}{ }^{2-}$ concentration at CHN82-20PC is $\sim 102 \mu \mathrm{mol} \mathrm{kg}{ }^{-1}$ (calculated from nearest GEOSECS data). An increase in the admixture of SOW $\left(\left[\mathrm{CO}_{3}{ }^{2-}\right] \approx 80 \mu \mathrm{mol} \mathrm{kg}{ }^{-1}\right.$, assumed to be roughly the same as today) from the modern $5 \%$ to the glacial $50 \%$ would lower CHN82-20PC to $\sim 92 \mu \mathrm{mol}$ $\mathrm{kg}^{-1}$. Thus $\Delta \mathrm{CO}_{3}{ }^{2-}$ would have dropped from $23 \mu \mathrm{mol} \mathrm{kg}{ }^{-1}$ to $\sim 13 \mu \mathrm{mol} \mathrm{kg}{ }^{-1}$ (assuming 
negligible change in $\left[\mathrm{CO}_{3}{ }^{2 n}\right]_{\text {saturation }}$ ); this corresponds to a $D_{\mathrm{Zn}}$ of 7.1 and a predicted $\mathrm{Zn} / \mathrm{Ca}$ of $3.2 \mu \mathrm{mol} \mathrm{mol}^{-1}$.

\section{$\mathrm{Zn} / \mathrm{Ca}$ and inferred glacial circulation}

The above analyses suggest that $\mathrm{Zn} / \mathrm{Ca}$ can be used to test for a stronger presence of SOW in the North Atlantic during the LGM. Holocene and LGM depth profiles of $\mathrm{Zn} / \mathrm{Ca}$, based on the nine cores used in this study, are shown in Figure 4.11. C. wuellerstorfi values are again significantly higher than coexisting Uvigerina specimens in the two deepest cores, and Holocene C. kullenbergi data imply a partition coefficient close to 50 , comparable to the findings in Chapter 2 (Figure $4.11 \mathrm{a}$ ). Five of the eight $C$. wuellerstorfi Holocene values are in excellent agreement with estimates based on modern dissolved Si concentrations (Bainbridge, 1981) using a $D_{\mathrm{Zn}}$ of 9 (Figure 4.11b). The three Holocene samples that are higher than predicted are the same cores that were most elevated in Cd/Ca. Again, core V29-204 (1849 m) shows no elevation.

LGM C. wuellerstorfi $\mathrm{Zn} / \mathrm{Ca}$ values are similar to Holocene data above $\sim 2500 \mathrm{~m}$ and enriched below this depth, in general agreement with the glacial $\mathrm{Cd}_{\mathrm{W}}$ pattern. However, there is no clear $\mathrm{Zn} / \mathrm{Ca}$ increase with water depth in the four deepest cores. This hints that the deeper $\mathrm{Zn} / \mathrm{Ca}$ data may be affected by low glacial $\Delta \mathrm{CO}_{3}{ }^{2-}$ values. The CHN82-20PC LGM Zn/Ca value is $2.99 \pm 0.11 \mu \mathrm{mol} \mathrm{mol}^{-1}$, compared to $1.60 \pm 0.06 \mu \mathrm{mol}$ $\mathrm{mol}^{-1}$ for the Holocene and $\sim 1.6 \mu \mathrm{mol} \mathrm{mol}^{-1}$ predicted from modern seawater Si. The glacial value is significantly higher than the maxima predicted by the circulation models requiring increased preformed nutrients $\left(1.9 \mu \mathrm{mol} \mathrm{mol}^{-1}\right)$ or increased aging $(2.1 \mu \mathrm{mol}$ $\mathrm{mol}^{-1}$ ), and significantly lower than the maximum predicted by enhanced mixing with SOW $\left(4.0 \mu \mathrm{mol} \mathrm{mol}^{-1}\right)$. It is, however, very close to the value predicted by the mixing model when the effects of $\left[\mathrm{CO}_{3}{ }^{2-}\right]$ are included $\left(3.2 \mu \mathrm{mol} \mathrm{mol}{ }^{-1}\right)$.

In Figure 4.12, measured $\mathrm{Zn} / \mathrm{Ca}$ values from all four deep cores are compared to values predicted by each of the three glacial circulation models. The first two models (increased preformed nutrients and increased aging) clearly underestimate $\mathrm{Zn} / \mathrm{Ca}$ at all depths. Maximum predictions of the mixing model $\left(D_{\mathrm{Zn}}=9\right)$ significantly overestimate 
$\mathrm{Zn} / \mathrm{Ca}$ in the three deepest cores, and slightly underestimate it in the $2658 \mathrm{~m}$ core. However, predictions are in surprisingly good agreement with the three deepest cores when the effect of reduced $\left[\mathrm{CO}_{3}{ }^{2-}\right]$ is incorporated into the mixing model. Overall, the combined $\mathrm{Cd} / \mathrm{Ca}$ and $\mathrm{Zn} / \mathrm{Ca}$ data strongly argue for the increased influence of SOW during the LGM. Estimates range from $45 \% \mathrm{SOW}$ at $2658 \mathrm{~m}$ to $89 \%$ SOW at 3427 (Figure 4.13). Because the mixing model does not account for SOW aging within the glacial Atlantic (nor a possible increase in preformed SOW), these numbers are more relative than absolute. In other words, by the time it got to $\sim 42^{\circ} \mathrm{N}$, the true nutrient content of aged glacial SOW was probably somewhat higher than the chosen endmember composition, meaning that $89 \%$ is likely an overestimate of the actual mixing. This uncertainty should have a relatively small effect on the seawater $\mathrm{Zn}$ concentrations predicted from $\mathrm{Cd} / \mathrm{Ca}$ because a lower $\% \mathrm{SOW}$ would be compensated by a higher SOW $Z$ n value.

The dissolved $\mathrm{Zn}$ estimates derived from $\mathrm{Cd} / \mathrm{Ca}$ can be combined with $\mathrm{Zn} / \mathrm{Ca}$ data

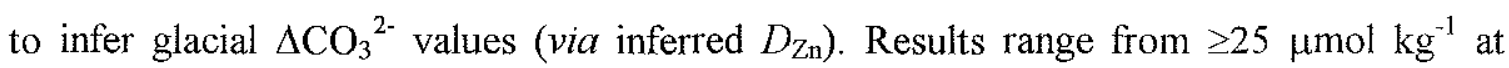
$2658 \mathrm{~m}$ to $\sim 0 \mu \mathrm{mol} \mathrm{kg}{ }^{-1}$ at $3427 \mathrm{~m}$. Assuming negligible changes in $\left[\mathrm{CO}_{3}{ }^{2-}\right]_{\text {saturation, }}$, these values suggest that $\left[\mathrm{CO}_{3}{ }^{2-}\right]_{\text {in situ }}$ dropped by a range of $\leq 4 \mu \mathrm{mol} \mathrm{kg}{ }^{-1}$ at $2658 \mathrm{~m}$ to $\sim 23$ $\mu \mathrm{mol} \mathrm{kg}{ }^{-1}$ at $3427 \mathrm{~m}$ (Figure 4.14). The increase of the drop's magnitude with depth is consistent with the increasing influence of SOW. The mean decrease below $3000 \mathrm{~m}$ is 17 $\mu \mathrm{mol} \mathrm{kg}{ }^{-1}$, of the same order as previous deep Atlantic estimates based on $\mathrm{CaCO}_{3}$ preservation (Broecker, 1995). Given all of the uncertainties involved, however, the present numbers should be taken as crude estimates only.

\section{Implications for glacial Atlantic $\delta^{13} \mathrm{C}$}

Glacial $\mathrm{P}$ concentrations estimated from my $\mathrm{Cd} / \mathrm{Ca}$ data and from previous $\delta^{13} \mathrm{C}$ data (using Equation 4.2 and assuming modern $\delta^{13} \mathrm{C}_{\mathrm{as}}$ from Lynch-Stieglitz and Fairbanks, 1994) are shown if Figure 4.15a. These data may not be directly comparable because the $\delta^{13} \mathrm{C}$ measurements are, in most cases, averaged over greater depth intervals in each core than the $\mathrm{Cd} / \mathrm{Ca}$ measurements, some of which may capture relatively 
extreme conditions (see Tables 4.2, 4.3; recall that this is not an issue for the $\mathrm{Zn} / \mathrm{Ca}$ measurements, which were made on the same dissolved samples as the $\mathrm{Cd} / \mathrm{Ca}$ measurements). Regardless, there are large disagreements between $\mathrm{Cd} / \mathrm{Ca}$ and $\delta^{13} \mathrm{C}$, especially in the deepest and shallowest cores. If the $\mathrm{Cd} / \mathrm{Ca}$ data are taken to be truly representative of LGM dissolved $\mathbf{P}$ concentrations, they can be used to calculate glacial $\delta^{13} \mathrm{C}_{\mathrm{as}}$ (Figure 4.15b). Values appear to decrease with increasing depth above $\sim 2500 \mathrm{~m}$ and increase with depth below $\sim 2500 \mathrm{~m}$, though there is a large amount of scatter in the data. The upper trend could be caused by a latitudinal $\delta^{13} \mathrm{C}_{\mathrm{as}}$ gradient in North Atlantic surface waters, with lower latitudes (shallow data) being enriched by greater rates of airsea exchange than high latitudes, where sea ice coverage was increased (CLIMAP, 1981). Lynch-Stieglitz and Fairbanks (1994) estimated that GNAIW in the 1000 to $2000 \mathrm{~m}$ depth range had a $\delta^{13} \mathrm{C}_{\text {as }}$ signature of $\sim 0.7 \%$, while deeper waters $(2000-3000 \mathrm{~m}$ ) were $\sim 0.2 \%$, in qualitative agreement with my data.

The deep $\delta^{13} \mathrm{C}_{\mathrm{as}}$ trend (which was not observed by Lynch-Stieglitz and Fairbanks [1994]) could represent mixing between lower GNAIW (having a relatively low signature) with SOW (having a high signature). Modern Antarctic surface water $\delta^{13} \mathrm{C}_{\text {as }}$ is close to $1 \%$, but $\mathrm{AABW}$ is $\sim 0.1 \%$ because of the contribution of upwelled deep waters (near -0.3\%o) (Lynch-Stieglitz and Fairbanks, 1994). My deep glacial data, which appear to require an SOW signature of at least $0.6 \%$, could possibly be explained by the higher signatures of deep waters upwelling in the Southern Ocean, combined with an increased incorporation of Antarctic surface waters. But if this were true, then deep Southern Ocean would also need to have a high signature; thus if deep Southern Ocean $\delta^{13} \mathrm{C}$ was near $-0.2 \%$ (Matsumoto and Lynch-Stieglitz, 1999), the nutrient-related portion would be about $-0.8 \%$ (i.e., $-0.8 \%$ o $0.6 \%=-0.2 \%$ ), corresponding to a North Pacific-like $\mathrm{P}$ concentration of $\sim 3 \mu \mathrm{mol} \mathrm{kg}{ }^{-1}\left([\mathrm{Cd}] \approx 0.9\right.$ nmol kg$\left.{ }^{-1}\right)$. This, in turn, means that glacial South Atlantic $\mathrm{Cd} / \mathrm{Ca}$ data near $0.15 \mu \mathrm{mol} \mathrm{mol}{ }^{-1}$ (Boyle, 1992) would require partition coefficients below 2. While such low $D_{\mathrm{Cd}}$ values have been observed elsewhere (McCorkle et al., 1995; Chapter 2), such high nutrient contents would require a fundamental reinterpretation of existing paleonutrient data. Alternatively, it is possible 
that my deep $\mathrm{Cd} / \mathrm{Ca}$ and $\mathrm{Zn} / \mathrm{Ca}$ measurements represent times of greater SOW influence than the $\delta^{13} \mathrm{C}$ data do, meaning that the deep $\delta^{13} \mathrm{C}_{\mathrm{as}}$ values could be overestimates. The low-latitude eastern North Atlantic data compiled by Beveridge et al. (1995) suggest deep $\delta^{13} \mathrm{C}_{\text {as }}$ values only $\sim 0.1 \%$ higher than today, thus requiring no glacial increase in the Southern Ocean signature. Of course, basic limits on the ability of benthic foraminifera to record seawater $\delta^{13} \mathrm{C}$ (Duplessy et al., 1984) and [Cd] (Boyle, 1995) may also explain part of the discrepancy. Note that the Holocene samples do not give a good match to the modern water column $\delta^{13} \mathrm{C}_{\text {as }}$ estimates of Lynch-Stieglitz and Fairbanks (1994) (Figure $4.15 b)$.

\section{Conclusions}

C. wuellerstorfi $\mathrm{Cd} / \mathrm{Ca}$ data from the North Atlantic suggest large increases in deep water nutrient contents during the LGM. In theory, such changes could have resulted from: (1) increased preformed nutrients in the high-latitude North Atlantic; (2) increased aging of lower NADW; or (3) decreased NADW production and greater mixing with SOW. $\mathrm{Zn} / \mathrm{Ca}$ data from the same samples are too high to be explained by the first two mechanisms. They require that SOW was a major contributor to the glacial North Atlantic deeper than about $2500 \mathrm{~m}$, implying that NADW was partially replaced by GNAIW. With this increased SOW influence came a significant lowering of deep North Atlantic $\mathrm{CO}_{3}{ }^{2-}$ concentrations, on the order of 10 to $20 \mu \mathrm{mol} \mathrm{kg}{ }^{-1}$. The $\mathrm{Cd} / \mathrm{Ca}$ data also imply that average glacial Atlantic $\delta^{13} \mathrm{C}_{\mathrm{as}}$ values were much higher than today. Thus, although previous interpretations of $\delta^{13} \mathrm{C}$ and $\mathrm{Cd} / \mathrm{Ca}$ data appear to be generally valid in terms of reduced NADW formation during the LGM, much complexity remains. A better understanding of the effect of $\Delta \mathrm{CO}_{3}{ }^{2-}$ on benthic foraminiferal $\mathrm{Cd} / \mathrm{Ca}$ is essential for reconstructing the details of glacial deep circulation. Further research into the controls on planktonic foraminiferal $\mathrm{Cd} / \mathrm{Ca}$ would also be useful for constraining glacial $\delta^{13} \mathrm{C}_{\mathrm{as}}$, which is crucial for interpreting benthic $\delta^{13} \mathrm{C}$ data. 


\section{References}

Bainbridge, A. E., GEOSECS Atlantic Expedition, Vol. l, Hydrographic Data, U. S. Government Printing Office, Washington, 1981.

Bertram, C. J., H. Elderfield, N. J. Shackleton, and J. A. MacDonald, Cadmium/calcium and carbon isotope reconstructions of the glacial northeast Atlantic Ocean, Paleoceanography, 10, 563-578, 1995.

Beveridge, N. A. S., H. Elderfield, and N. J. Shackleton, Deep thermohaline circulation in the low-latitude Atlantic during the last glacial, Paleoceanography, 10, 643-660, 1995.

Boyle, E. A., Cadmium: Chemical tracer of deepwater paleoceanography, Paleoceanography, 3, 471-489, 1988.

Boyle, E. A., Cadmium and $\delta^{13} \mathrm{C}$ paleochemical ocean distributions during the Stage 2 glacial maximum, Annu. Rev. Earth Planet. Sci., 20, 245-287, 1992.

Boyle, E. A., Limits on benthic foraminiferal chemical analyses as precise measures of environmental properties, J. Foram. Res., 25, 4-13, 1995.

Boyle, E. A., and L. D. Keigwin, Deep circulation of the North Atlantic over the last 200,000 years: Geochemical evidence, Science, 218, 784-787, 1982.

Boyle, E. A., and L. D. Keigwin, Comparison of Atlantic and Pacific paleochemical records for the last 215,000 years: changes in deep ocean circulation and chemical inventories, Earth Planet. Sci. Lett., 76, 135-150, 1985/86.

Boyle, E. A., and L. D. Keigwin, North Atlantic thermohaline circulation during the last 20,000 years linked to high latitude surface temperature, Nature, 330, 35-40, 1987.

Boyle, E. A., and Y. Rosenthal, Chemical hydrography of the South Atlantic during the last glacial maximum: $\mathrm{Cd}$ vs. $\delta^{13} \mathrm{C}$, in The South Atlantic: Present and Past Circulation, edited by G. Wefer et al., pp. 423-443, Springer-Verlag, Berlin, 1996.

Broecker, W. S., The Glacial World According to Wally, Eldigio Press, Palisades, NY, 1995.

Broecker, W. S., and E. Maier-Reimer, The influence of air and sea exchange on the carbon isotope distribution in the sea, Global Biogeochem. Cycles, 6, 315-320, 1992.

Broecker, W. S., and T.-H. Peng, Tracers in the Sea, Eldigio Press, Palisades, NY, 1982. 
Broecker, W. S., S. Blanton, W. M. Smethie, and G. Ostlund, Radiocarbon decay and oxygen utilization in the deep Atlantic Ocean, Glob. Biogeochem. Cycles, 5, 87-117, 1991.

Bruland, K. W., and R. P. Franks, Mn, Ni, Cu, $\mathrm{Zn}$ and $\mathrm{Cd}$ in the western North Atlantic, in Trace Metals in Seawater, NATO Conf. Ser. 4, Marine Science Vol. 9, pp. 395-414, Plenum, 1983.

Bruland, K. W., G. A. Knauer, and J. H. Martin, Zinc in north-east Pacific water, Nature, 271, 741-743, 1978.

CLIMAP Project Members, Seasonal reconstructions of the Earth's surface at the Last Glacial Maximum, Geological Society of America Map Chart Service, Boulder, CO, 1981.

Curry, W. B., and G. P. Lohmann, Carbon isotopic changes in benthic foraminifera from the western South Atlantic: Reconstruction of glacial abyssal circulation patterns, Quat. Res., I8, 218-235, 1982.

Curry, W. B., T. M. Marchitto, J. F. McManus, D. W. Oppo, and K. L. Laarkamp, Millennial-scale changes in ventilation of the thermocline, intermediate, and deep waters of the glacial North Atlantic, in Mechanisms of Global Climate Change at Millennial Time Scales, edited by P. U. Clark and R. S. Webb, AGU Monograph, in press.

Duplessy, J.-C., L. Cherrouard, and F. Vila, Weyl's theory of glaciation supported by isotopic study of Norwegian core K11, Science, 188, 1208-1209, 1975.

Duplessy, J.-C., N. J. Shackleton, R. K. Matthews, W. L. Prell, W. F. Ruddiman, M. Caralp, and C. H. Hendy, ${ }^{13} \mathrm{C}$ record of benthic foraminifera in the last interglacial ocean: implications for the carbon cycle and the global deep water circulation, Quat. Res., 21, 225-243, 1984.

Duplessy, J.-C., N. J. Shackleton, R. G. Fairbanks, L. Labeyrie, D. Oppo, and N. Kallel, Deepwater source variations during the last climatic cycle and their impact on the global deepwater circulation, Paleoceanography, 3, 343-360, 1988.

Haskell, B. J., T. C. Johnson, and W. J. Showers, Fluctuations in deep western North Atlantic circulation on the Blake Outer Ridge during the last deglaciation, Paleoceanography, 6, 21-31, 1991.

Keigwin, L. D., and E. A. Boyle, Late Quaternary paleochemistry of high-latitude surface waters, Palaeogeogr., Palaeoclim., Palaeoecol., 73, 85-106, 1989. 
Keigwin, L. D., and S. J. Lehman, Deep circulation change linked to HEINRICH event 1 and Younger Dryas in a middepth North Atlantic core, Paleoceanography, 9, 185194, 1994.

Kroopnick, P. M., The distribution of ${ }^{13} \mathrm{C}$ of $\Sigma \mathrm{CO}_{2}$ in the world oceans, Deep-Sea Res., $32,57-84,1985$.

Ledbetter, M. T., and W. L. Balsam, Paleoceanography of the Deep Western Boundary Undercurrent on the North American continental margin for the past 25,000 yr, Geology, 13, 181-184, 1985.

LeGrand, P., and C. Wunsch, Constraints from paleotracer data on the North Atlantic circulation during the last glacial maximum, Paleoceanography, 10, 1011-1046, 1995.

Lynch-Stieglitz, J., and R. G. Fairbanks, A conservative tracer for glacial ocean circulation from carbon isotope and palaeo-nutrient measurements in benthic foraminifera, Nature, 369, 308-310, 1994.

Lynch-Stieglitz, J., A. van Geen, and R. G. Fairbanks, Interocean exchange of Glacial North Atlantic Intermediate Water: Evidence from Subantarctic $\mathrm{Cd} / \mathrm{Ca}$ and carbon isotope measurements, Paleoceanography, 11, 191-201, 1996.

Mackensen, A., H.-W. Hubberten, T. Bickert, G. Fischer, and D. K. Fütterer, The $\delta^{13}$ C in benthic foraminiferal tests of Fontbotia wuellerstorfi (Schwager) relative to the $\delta^{13} \mathrm{C}$ of dissolved inorganic carbon in Southern Ocean deep water: Implications for glacial ocean circulation models, Paleoceanography, 8, 587-610, 1993.

Marchitto, T. M., W. B. Curry, and D. W. Oppo, Millennial-scale changes in North Atlantic circulation since the last glaciation, Nature, 393, 557-561, 1998.

Martin, W. R., and F. L. Sayles, $\mathrm{CaCO}_{3}$ dissolution in sediments of the Ceara Rise, western equatorial Atlantic, Geochim. Cosmochim. Acta, 60, 243-263, 1996.

Matsumoto, K., and J. Lynch-Stieglitz, Similar glacial and Holocene deep water circulation inferred from southeast Pacific benthic foraminiferal carbon isotope composition, Paleoceanography, 14, 149-163, 1999.

McCave, I. N., B. Manighetti, and N. A. S. Beveridge, Circulation in the glacial North Atlantic inferred from grain-size measurements, Nature, 374, 149-152, 1995.

McCorkle, D. C., P. A. Martin, D. W. Lea, and G. P. Klinkhammer, Evidence of a dissolution effect on benthic foraminiferal shell chemistry: $\delta^{13} \mathrm{C}, \mathrm{Cd} / \mathrm{Ca}, \mathrm{Ba} / \mathrm{Ca}$, 
and $\mathrm{Sr} / \mathrm{Ca}$ results from the Ontong Java Plateau, Paleoceanography, 10, 699-714, 1995.

McManus, J. F., D. W. Oppo, and J. L. Cullen, A 0.5-million-year record of millennialscale climate variability in the North Atlantic, Science, 283, 971-975, 1999.

Mix, A. C., and R. G. Fairbanks, North Atlantic surface-ocean control of Pleistocene deep-ocean circulation, Earth Planet. Sci. Lett., 73, 231-243, 1985.

Newell, R. E., Changes in the poleward energy flux by the atmosphere and ocean as a possible cause for Ice Ages, Quat. Res., 4, 117-127, 1974.

Oppo, D. W., and R. G. Fairbanks, Variability in the deep and intermediate water circulation of the Atlantic Ocean during the past 25,000 years: Northern Hemisphere modulation of the Southern Ocean, Earth Planet. Sci. Lett., 86, 1-15, 1987.

Oppo, D. W., and S. J. Lehman, Mid-depth circulation of the subpolar North Atlantic during the Last Glacial Maximum, Science, 259, 1148-1152, 1993.

Oppo, D. W., and S. J. Lehman, Suborbital timescale variability of North Atlantic Deep Water during the past 200,000 years, Paleoceanography, 10, 901-910, 1995.

Rau, G. H., P. N. Froelich, T. Takahashi, and D. J. Des Marais, Does sedimentary organic $\delta^{13} \mathrm{C}$ record variations in Quaternary ocean $\left[\mathrm{CO}_{2}(\mathrm{aq})\right]$ ?, Paleoceanography, 6, 335$347,1991$.

Rickaby, R. E. M., and H. Elderfield, Planktonic foraminiferal Cd/Ca: Paleonutrients or paleotemperature?, Paleoceanography, 14, 293-303, 1999.

Rosenthal, Y., Late Quaternary paleochemistry of the Southern Ocean: Evidence from cadmium variability in sediments and foraminifera, Ph.D. thesis, Mass. Inst. of Technol./Woods Hole Oceanogr. Inst. Joint Program in Oceanogr., Cambridge, MA, 1994.

Sarnthein, M., et al., Changes in east Atlantic deepwater circulation over the last 30,000 years: Eight time slice reconstructions, Paleoceanography, 9, 209-267, 1994.

Tomczak, M., and J. S. Godfrey, Regional Oceanography: An Introduction, Pergamon, Oxford, 1994.

Weyl, P. K., The role of the oceans in climatic change: A theory of the Ice Ages, Meteorol. Monogr., Vol. 8, No. 30, 37-62, 1968. 
Williamowski, C., and R. Zahn, The past $40 \mathrm{kyr}$ of North Atlantic thermohaline circulation: Benthic $\delta^{13} \mathrm{C}$ and $\mathrm{Cd} / \mathrm{Ca}$ reference sections from the Portuguese and Moroccan Margins, Eos, Transactions, $A G U$, 79, S180, 1998.

Zahn, R., K. Wynn, and M. Sarnthein, Benthic foraminiferal $\delta^{13} \mathrm{C}$ and accumulation rates of organic carbon: Uvigerina peregrina group and Cibicidoides wuellerstorfi, Paleoceanography, 1, 27-42, 1986. 
Figure 4.1. (next page) Modern dissolved $\mathrm{Zn}$ (top) and Cd (bottom) concentrations in the western Atlantic Ocean, estimated from GEOSECS dissolved Si and $\mathrm{P}$ measurements (Bainbridge, 1981), respectively. 


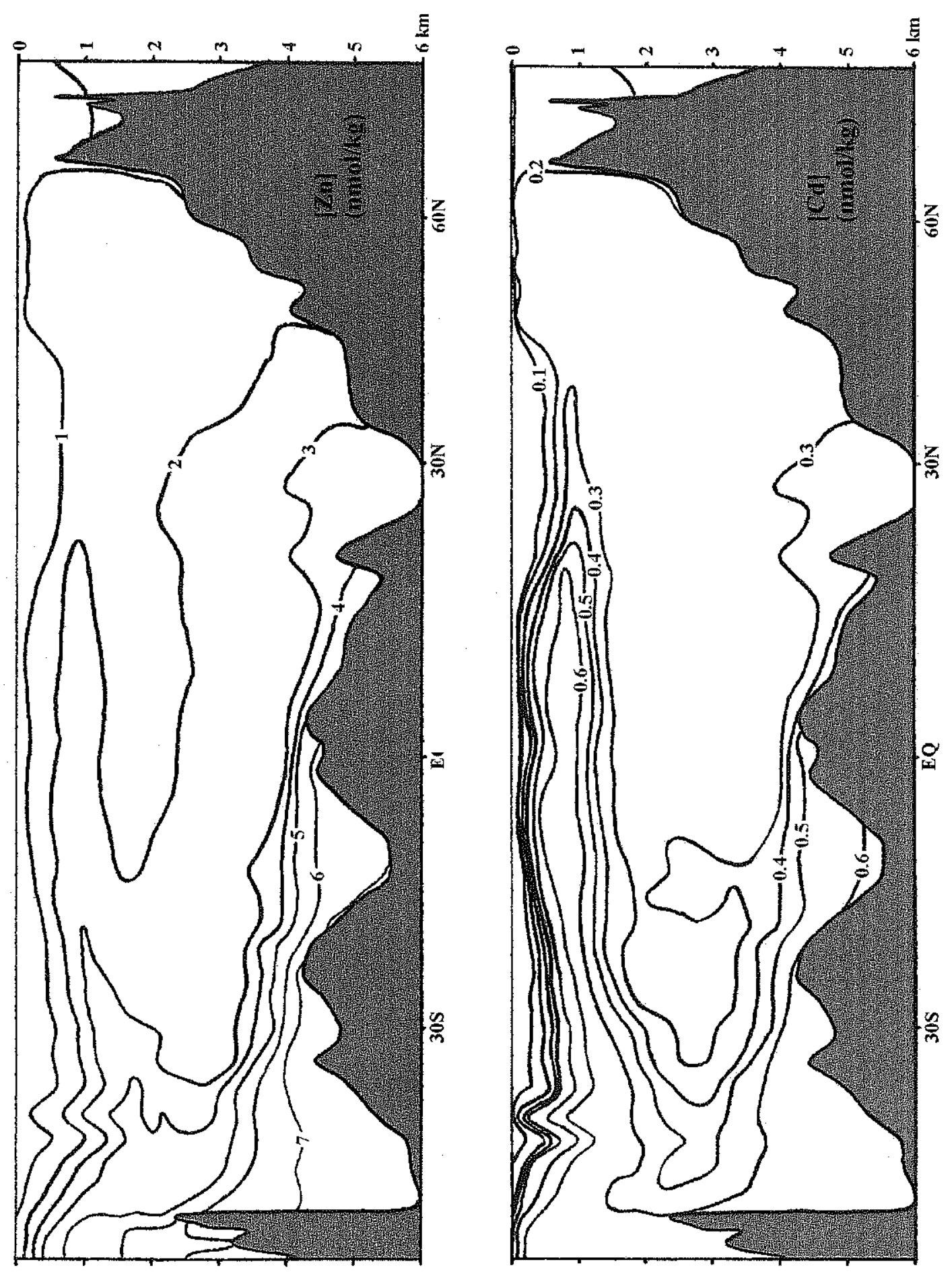




\section{Depth Transect Cores}

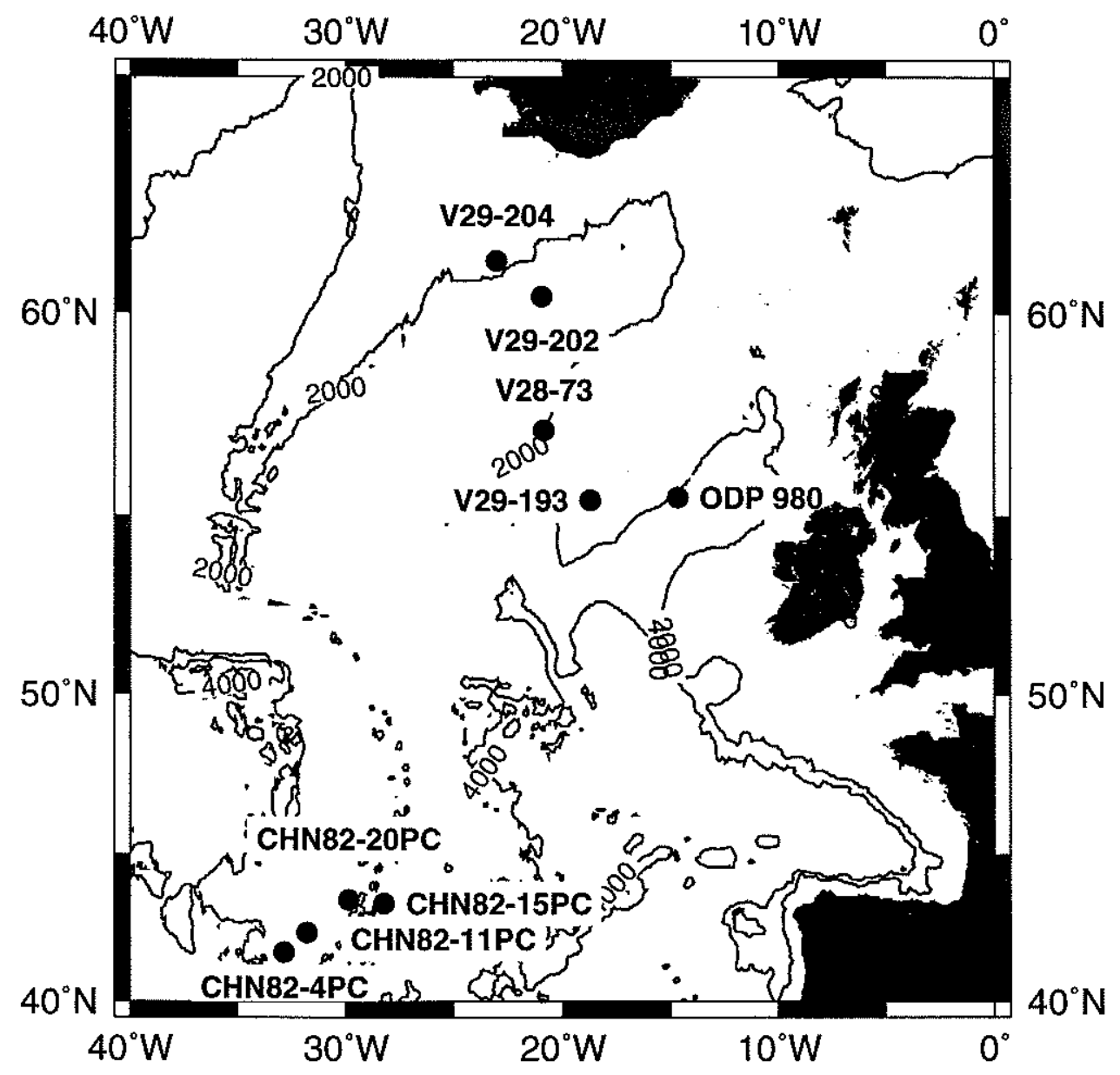

Figure 4.2. Locations of sediment cores used in this study, North Atlantic Ocean. 


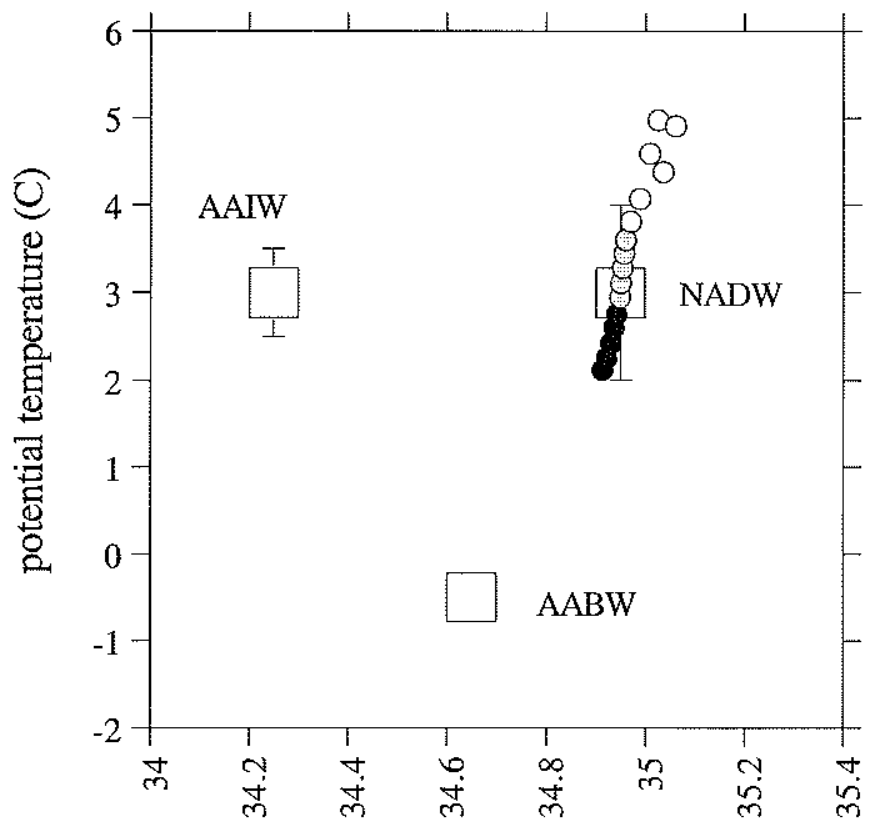

salinity (S)

Figure 4.3. Potential T-S diagram showing GEOSECS Station 27 (42N, 42W; circles) in relation to three Atlantic end-members (squares). Station 27 data are from 1000-2000 m (open), 2000-3000 m (shaded), and 3000-4000 m (filled). End-member picks are mainly from Tomczak and Godfrey (1994). NADW includes Broecker and Peng's (1982) NCW and Labrador Sea Water. AABW is similar to Broecker and Peng's (1982) SCW. Warm and saline Eurafrican Mediterranean Water, which has a small influence on the shallow data at Station 27, is not shown. 

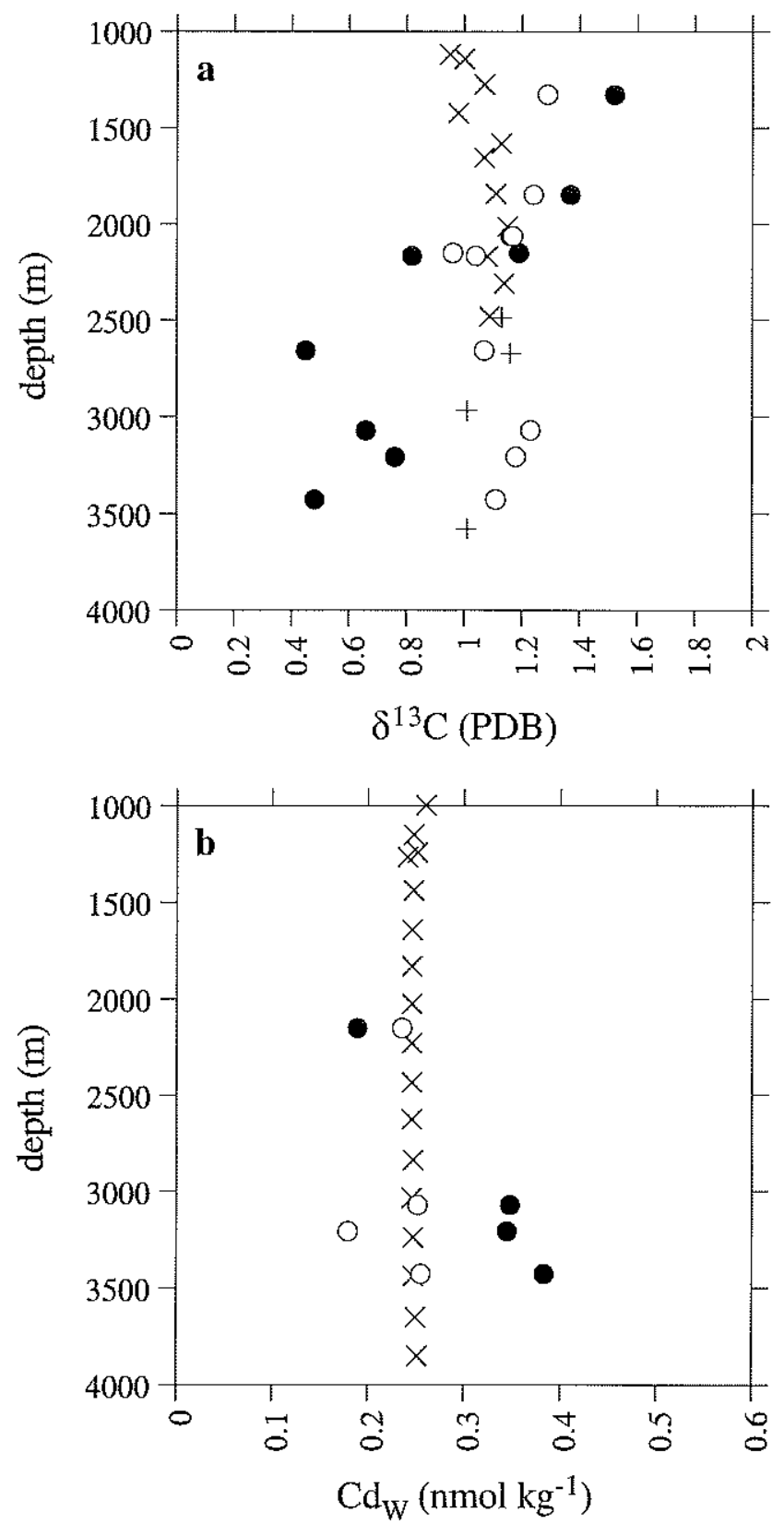

Figure 4.4. Depth profiles of published $\delta^{13} \mathrm{C}$ (a) and published $\mathrm{Cd}_{\mathrm{W}}$ (b) from the cores used in this study (see Table 4.2 for references). Holocene data are open and LGM data are filled. $\delta^{13} \mathrm{C}$ data are from $C$. wuellerstorfi and C. kullenbergi. $\mathrm{Cd}_{\mathrm{W}}$ data are from the same species plus Uvigerina spp. Modern water column $\delta^{13} \mathrm{C}$ estimates are from GEOSECS Stations 23 (60N, 19W; exes) and 26 (45N, 42W; crosses) (Kroopnick, 1985). Modern $\mathrm{Cd}_{\mathrm{W}}$ estimates are based on dissolved P from Station 27 (42N, 42W; exes) (Bainbridge, 1981). 

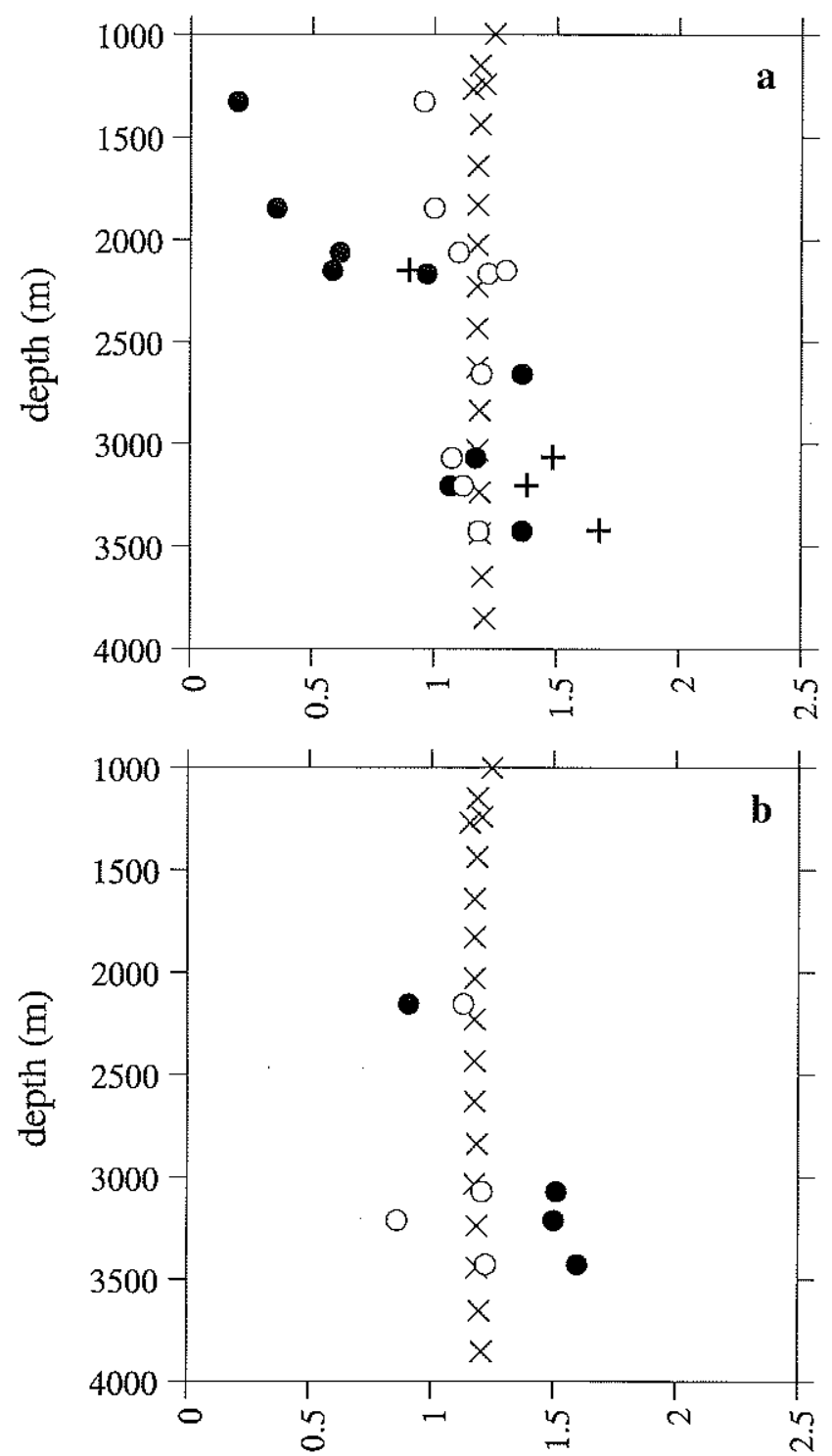

equivalent $\mathrm{P}\left(\mu \mathrm{mol} \mathrm{kg}{ }^{-1}\right)$

Figure 4.5. Estimates of seawater $\mathrm{P}$ based on published $\delta^{13} \mathrm{C}$ (a) and published $\mathrm{Cd} / \mathrm{Ca}$ (b) from the cores used in this study. Holocene data are open and LGM data are filled. Modern P measurements (exes) are from GEOSECS Station 27 (42N, 42W). Estimates based on $\delta^{13} \mathrm{C}$ assume modern $\delta^{13} \mathrm{C}_{\text {as }}$ values $(-0.35$ to -0.28 per mil; Lynch-Stieglitz and Fairbanks, 1994). Crosses show LGM values at CHN82 sites assuming $\delta^{13} \mathrm{C}_{\mathrm{as}}$ values 0.3 per mil higher than today, producing reasonable agreement with the $\mathrm{Cd} / \mathrm{Ca}$ data from those cores. 

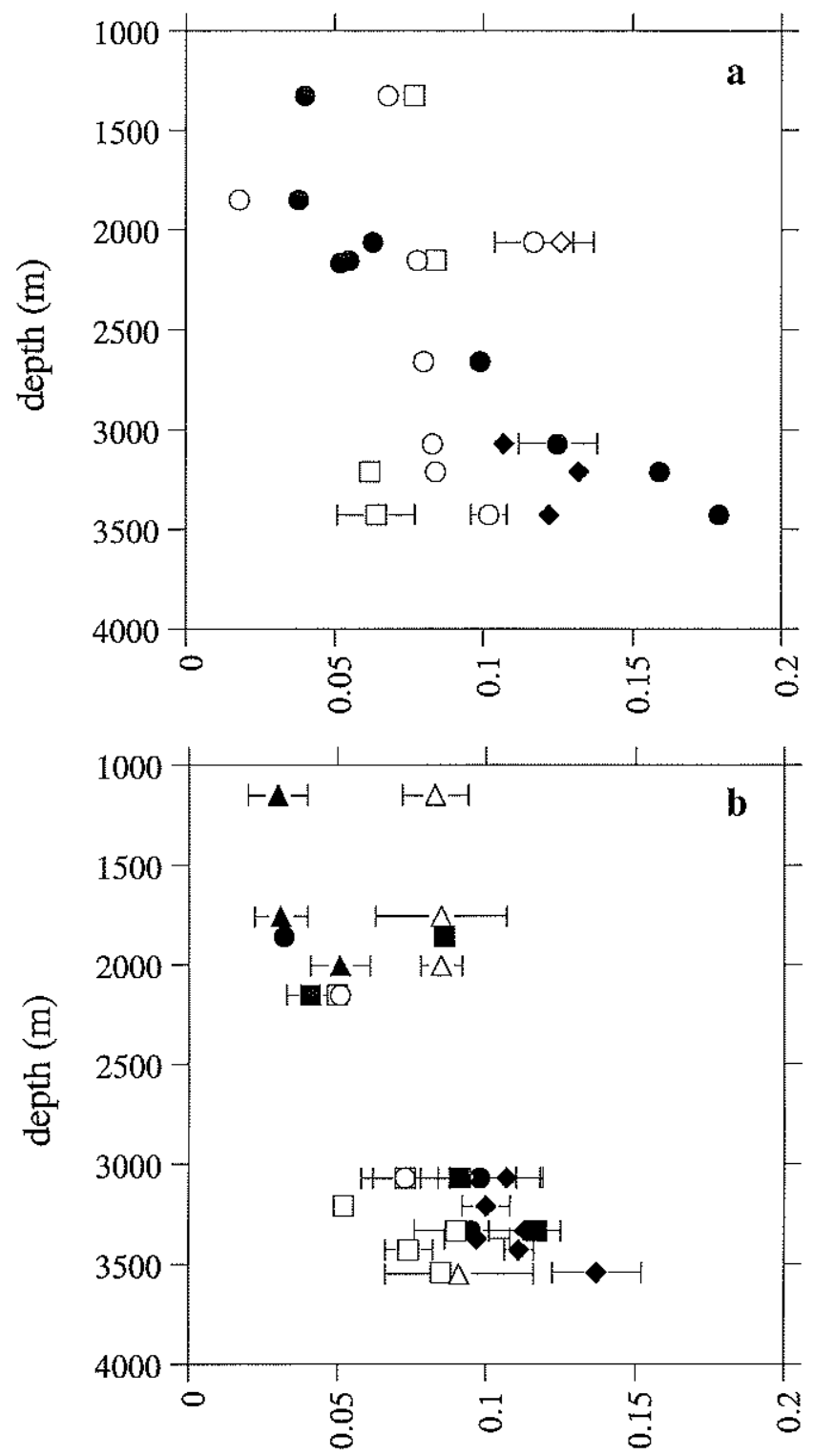

$\mathrm{Cd} / \mathrm{Ca}\left(\mu \mathrm{mol} \mathrm{mol}{ }^{-1}\right)$

Figure 4.6. New $\mathrm{Cd} / \mathrm{Ca}$ data from this study (a) and from published North Atlantic cores north of 40N (b; Boyle, 1992; Bertram et al., 1995). Holocene data are open, LGM data are filled. Taxa are C. wuellerstorfi (circles), C. kullenbergi (squares), and Uvigerina (diamonds). Triangles are mixes of these taxa from Bertram et al. (1995). Error bars are $+/-1 \sigma$ of replicates. 


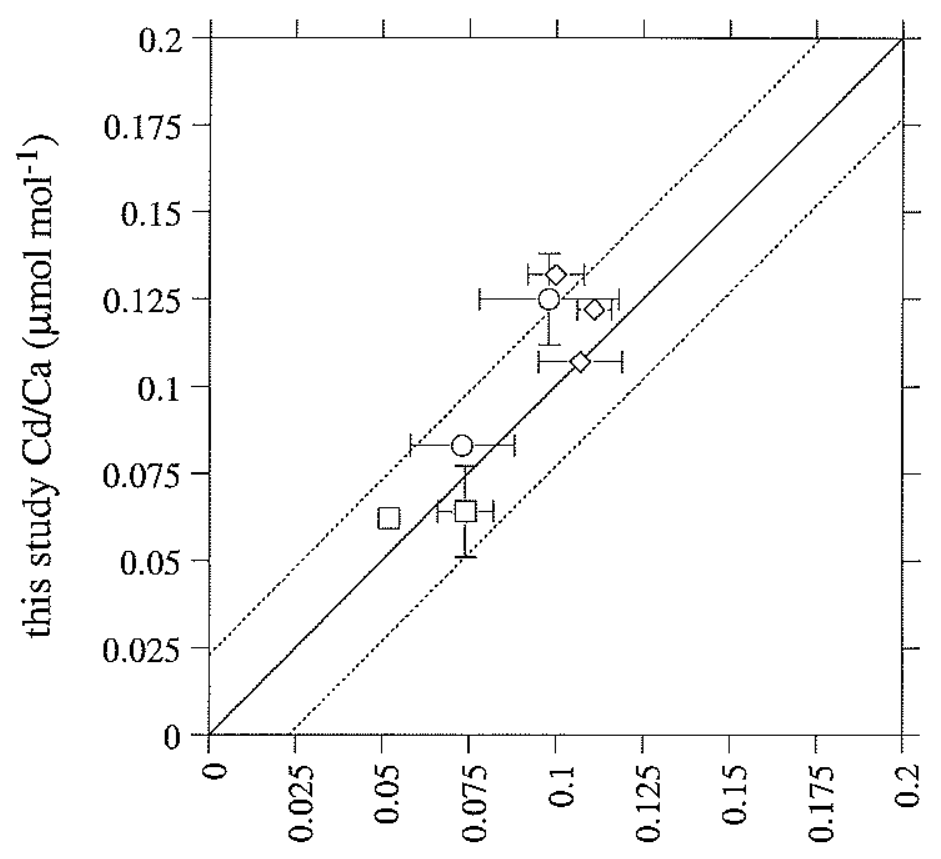

Boyle $\mathrm{Cd} / \mathrm{Ca}\left(\mu \mathrm{mol} \mathrm{mol}{ }^{-1}\right)$

Figure 4.7. Comparison of $\mathrm{Cd} / \mathrm{Ca}$ data from the three deep CHN82 cores, measured by Boyle (Boyle and Keigwin 1982, 1985/6; Boyle, 1988, 1992) and from this study. Most of Boyle's data are averaged over greater depth intervals than the data from this study. Taxa are $C$. wuellersorfi (circles), C. kullenbergi (squares), and Uvigerina (diamonds). Error bars are $+/-1 \sigma$. Dotted lines trace an envelope of $+/-0.023 \mu \mathrm{mol}$ $\mathrm{mol}^{-1}$, an estimate of expected reproduceability based on separate picks from the same sample (Boyle, 1995). 


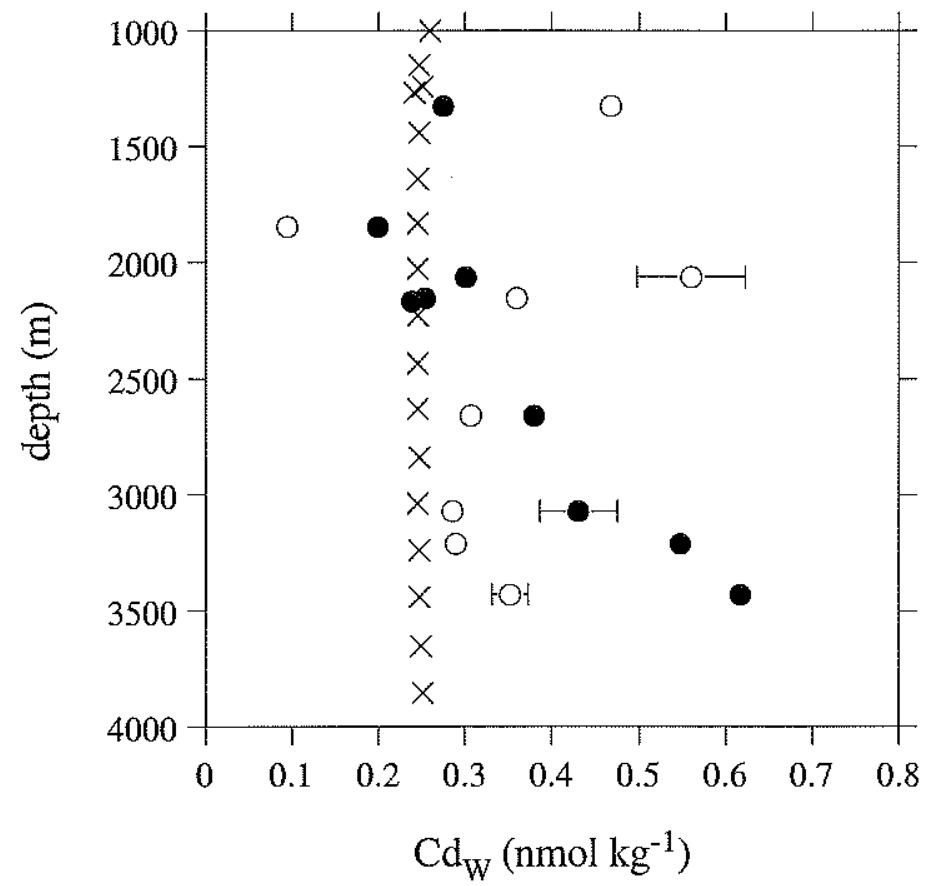

Figure 4.8. Depth transects of Holocene (open) and LGM (solid) $\mathrm{Cd}_{\mathrm{W}}$ based on $C$. wuellerstorfi from this study. Modern estimates (exes) are based on $\mathrm{P}$ measurements from GEOSECS Station $27(42 \mathrm{~N}, 42 \mathrm{~W})$. 


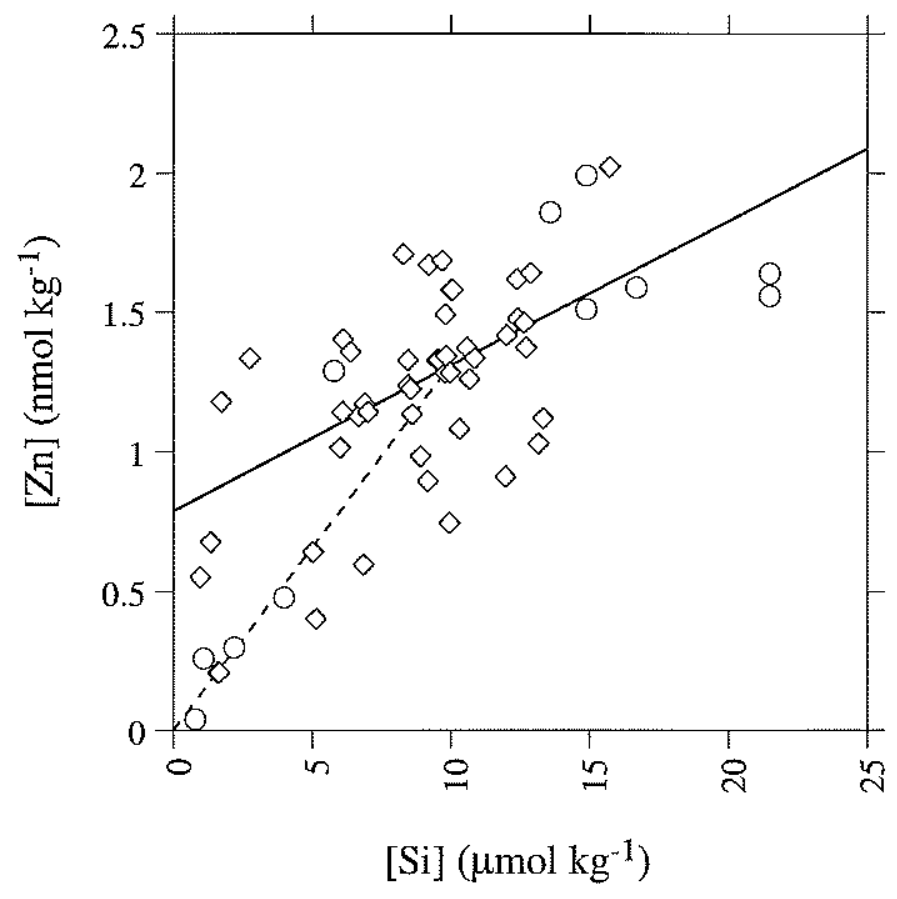

Figure 4.9. Blowup of the modern dissolved $\mathrm{Zn}: \mathrm{Si}$ relationship in the North Atlantic, showing measurements from all depths. Data are from Bruland and Franks (1983) (circles) and Yeats and Dalziel (unpublished data) (diamonds). Solid line shows the global relationship for waters deeper than $1000 \mathrm{~m}$ (Chapter 2, Figure 2.2). Dashed line shows an approximate relationship for shallower waters $(\mathrm{Zn}=0.131 \mathrm{Si})$. Note that shallow data from the Pacific do not necessarily follow this trend. 


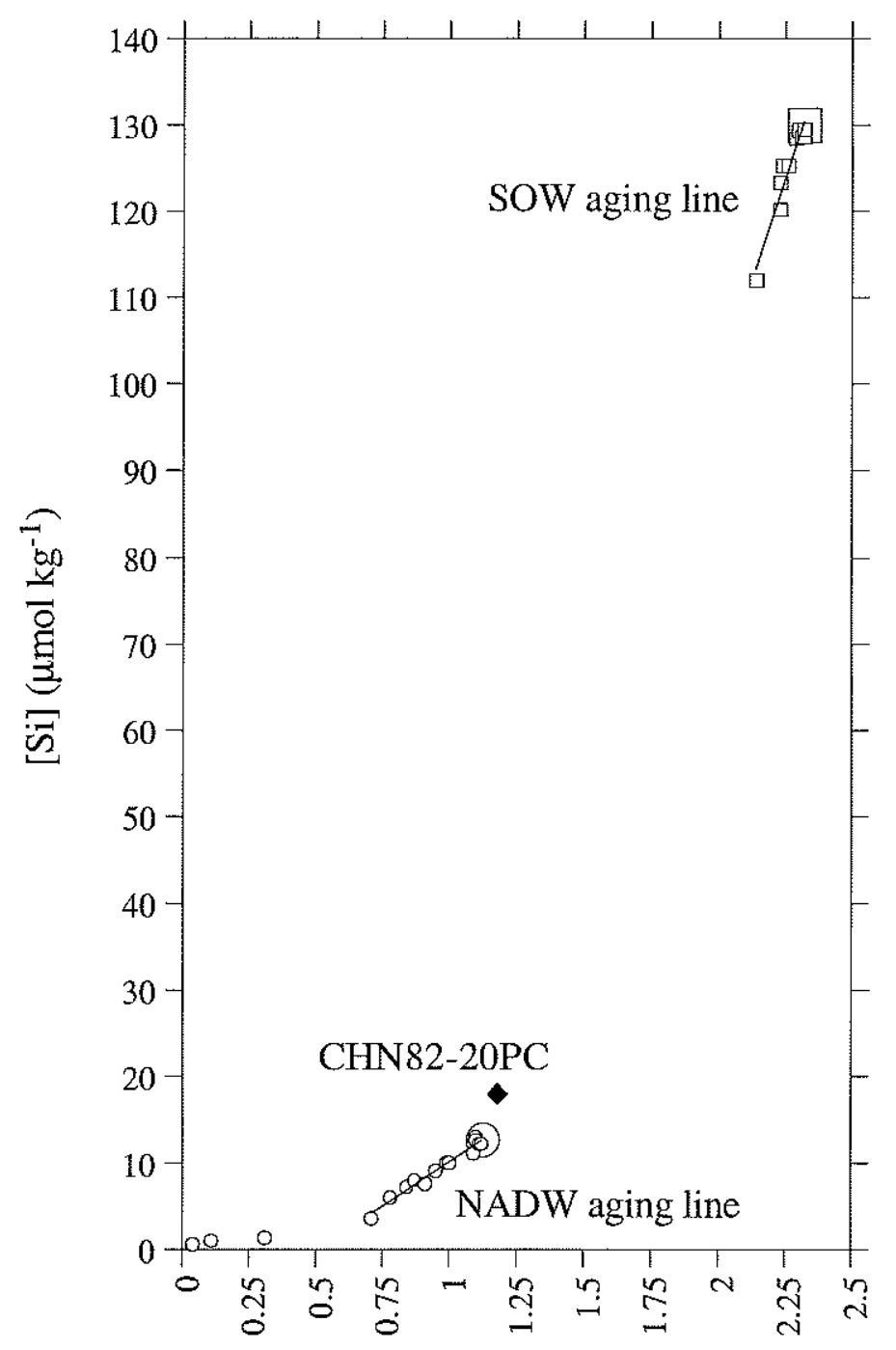

[P] $\left(\mu \mathrm{mol} \mathrm{kg}^{-1}\right)$

Figure 4.10. Mixing diagram for modern waters above CHN82-20PC (44N, 30W, $3070 \mathrm{~m}$ ). Small circles are GEOSECS measurements from surface waters in the Greenland Sea at 72N (Station 16) through the core of NADW ( 2000 m) as far south as $45 \mathrm{~N}$ (Station 1). Line (best fit) represents aging of NADW independent of mixing with waters of southern origin. Lowest point along this line is taken to represent preformed NADW. Small squares are GEOSECS measurements along an AABW isopycnal, increasing from 60S (Station 79) to $45 \mathrm{~S}$ (Station 67), plus the Weddell Sea Bottom Water end-member chosen by Broecker and Peng (1982) (lowest point). Line (best fit) represents aging of $\mathrm{AABW}$ independent of mixing with NADW. The maximum observed values in AABW (large square) are chosen as the fixed "aged SOW" end-member. The "aged NADW" end-member (large circle) is calculated by extending the mixing line between aged SOW and CHN82-20PC (diamond is nearest GEOSECS measurements) to the NADW aging line. 

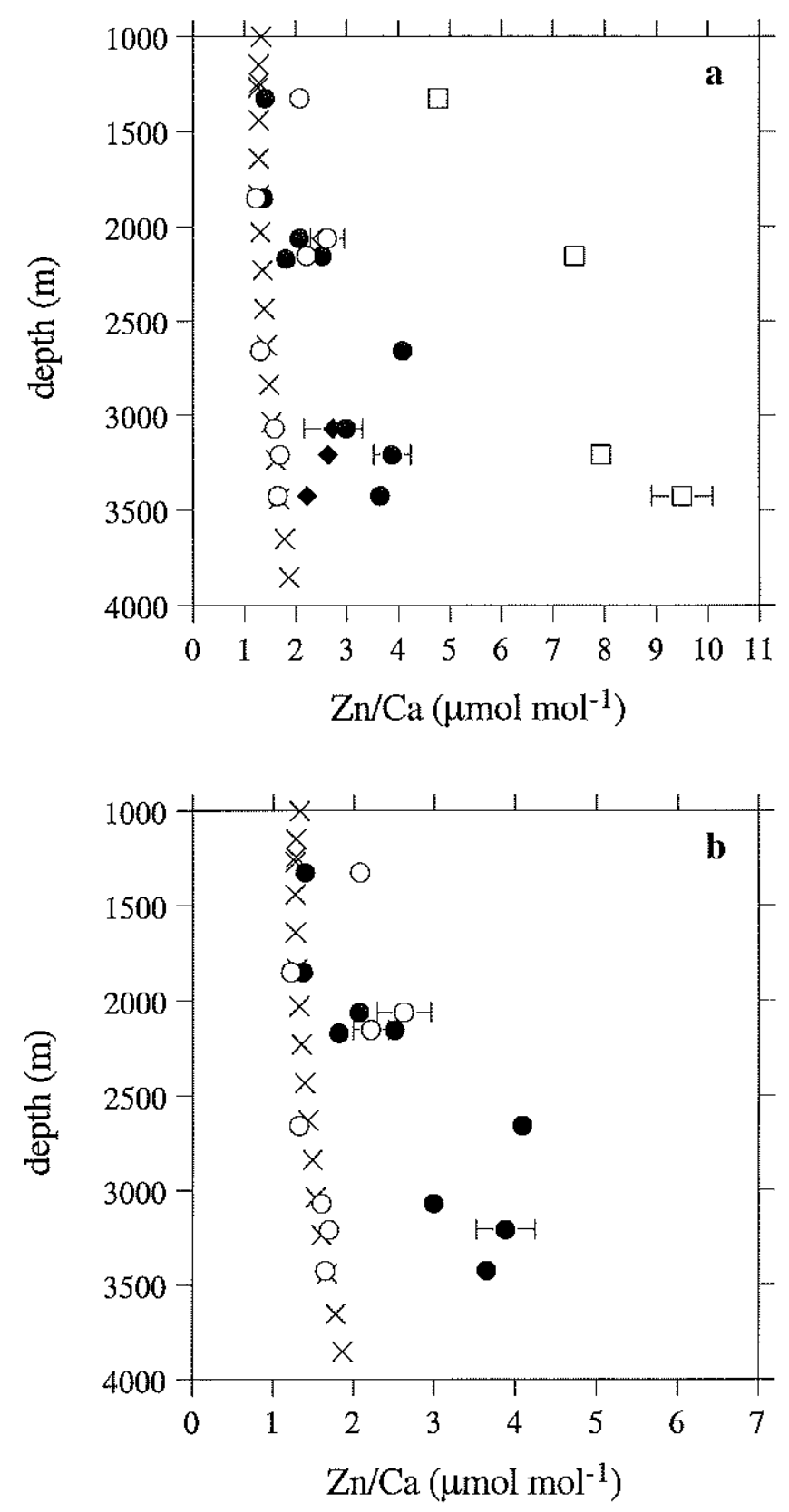

Figure 4.11. $\mathrm{Zn} / \mathrm{Ca}$ values in Holocene (open) and LGM (filled) samples of $C$. whellerstorfi (circles), Uvigerina (diamonds), and C. kullenbergi (squares). Error bars are $+/-1 \sigma . C$. kullenbergi is known to be greatly elevated in $\mathrm{Zn}$ relative to $C$. wuellerstorfi and Uvigerina. Also shown (exes) are modern estimates based on GEOSECS dissolved Si using a partition coefficient of 9. Panel (a) shows all three taxa, while panel (b) shows $C$. wuellerstorfi only. 


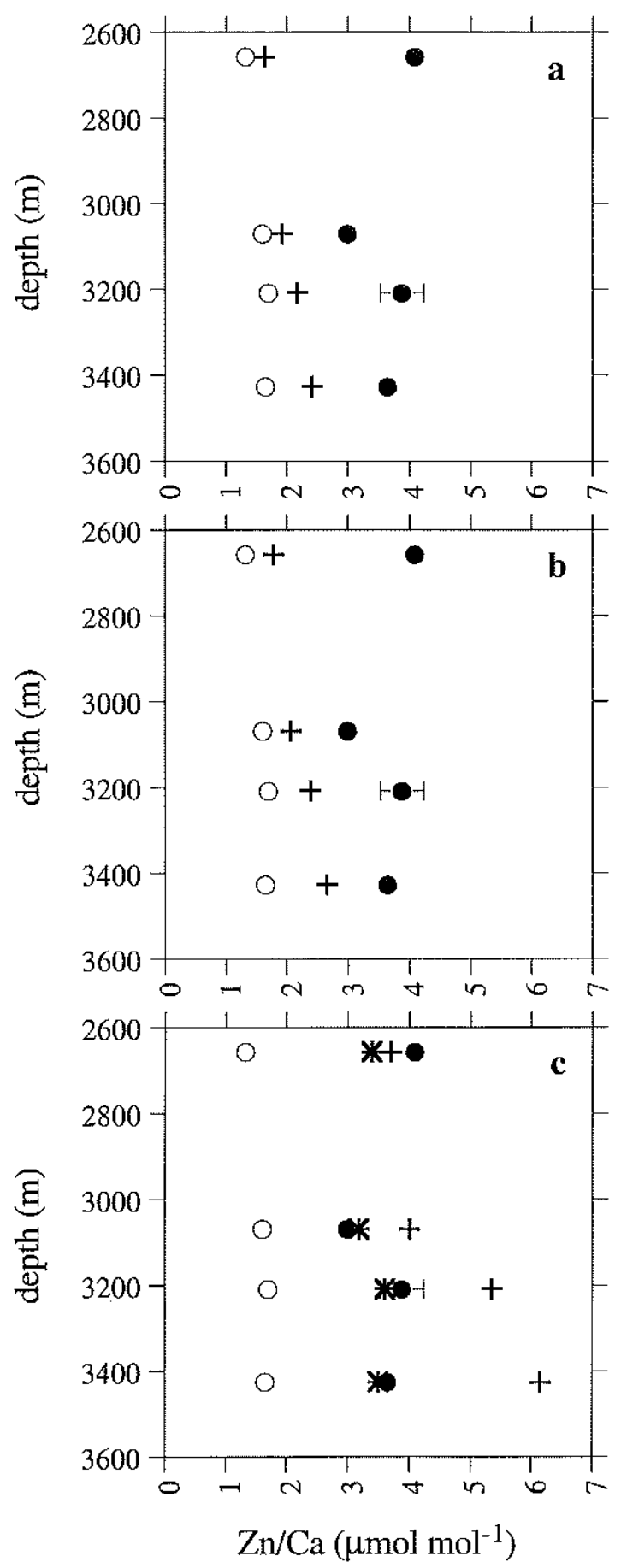

Figure 4.12. Holocene (open circles) and LGM (filled circles) C. wuellerstorfi $\mathrm{Zn} / \mathrm{Ca}$ values compared to LGM predictions based on $\mathrm{Cd} / \mathrm{Ca}$ data, assuming a $\mathrm{Zn}$ partition coefficient of 9 (crosses). Panels correspond to the three glacial circulation scenarios $(\mathrm{a}=$ increased preformed NADW nutrients, $\mathrm{b}=$ increased NADW aging, $\mathrm{c}=$ increased mixing with SOW). In panel (c), asterisks show predictions that account for the reductions in $\left[\mathrm{CO}_{3}{ }^{2-}\right]$ and $D_{\mathrm{Zn}}$ expected by increased SOW. 


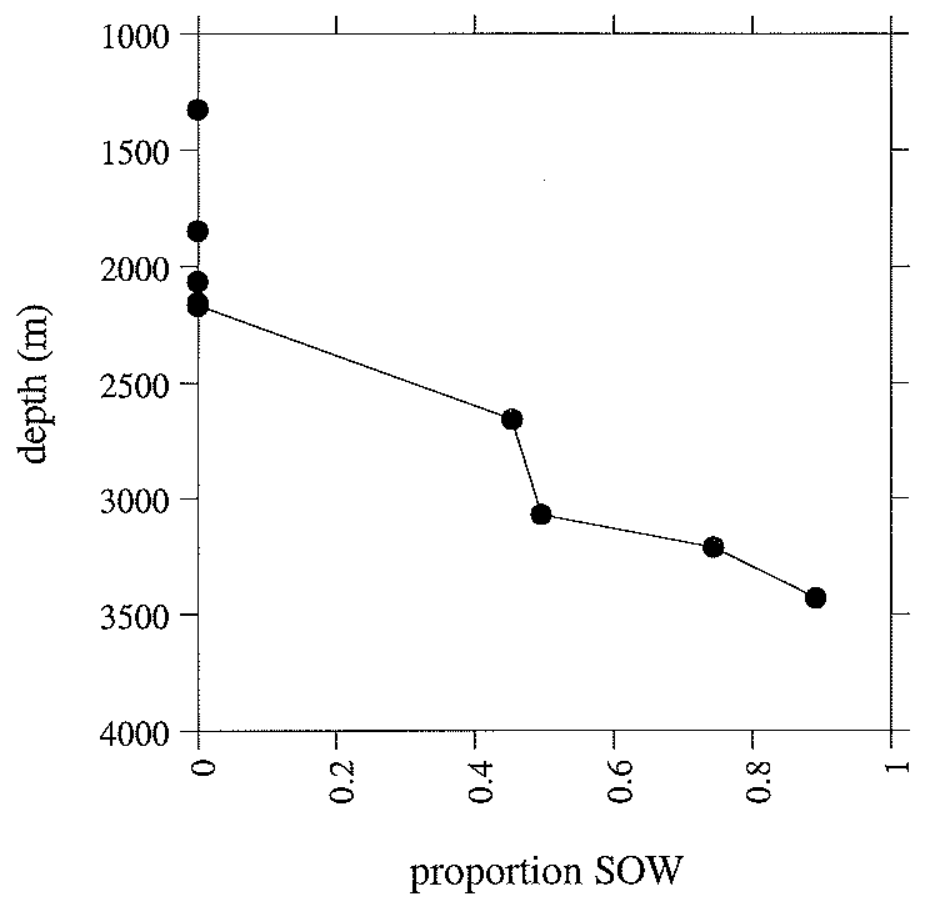

Figure 4.13. Proportion of SOW calculated at each core site during the LGM. Numbers are relative to a modern "aged AABW" end-member. Cores above $2500 \mathrm{~m}$, which had LGM Cd/Ca ratios similar to modern predictions, are assumed to have had no more than modern SOW proportions $(<1 \%)$. 


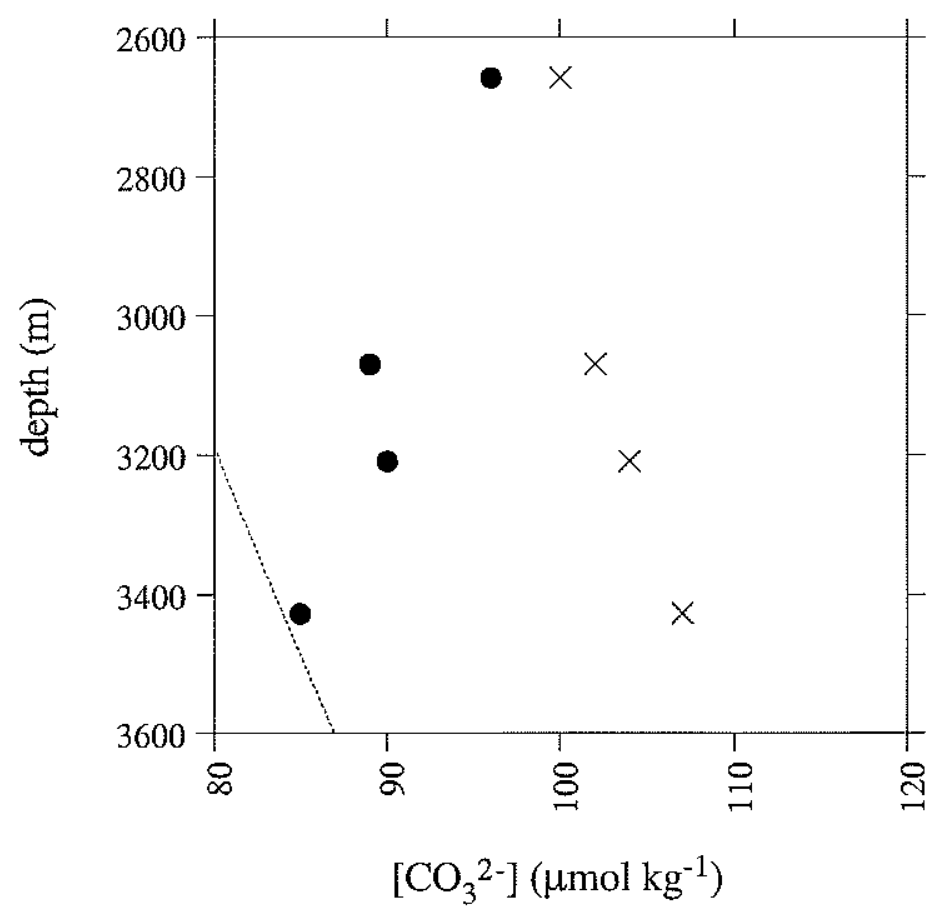

Figure 4.14. Carbonate ion concentrations calculated from GEOSECS data (exes) and estimated from LGM Zn/Ca data combined with seawater [Zn] predictions based on $\mathrm{Cd} / \mathrm{Ca}$ (circles). Shallowest LGM point is a minimum value, corresponding to an inferred $D_{\mathrm{Zn}}$ close to 9 . Dotted line shows the modern $\left[\mathrm{CO}_{3}{ }^{2-}\right]$ for saturation with respect to calcite. 


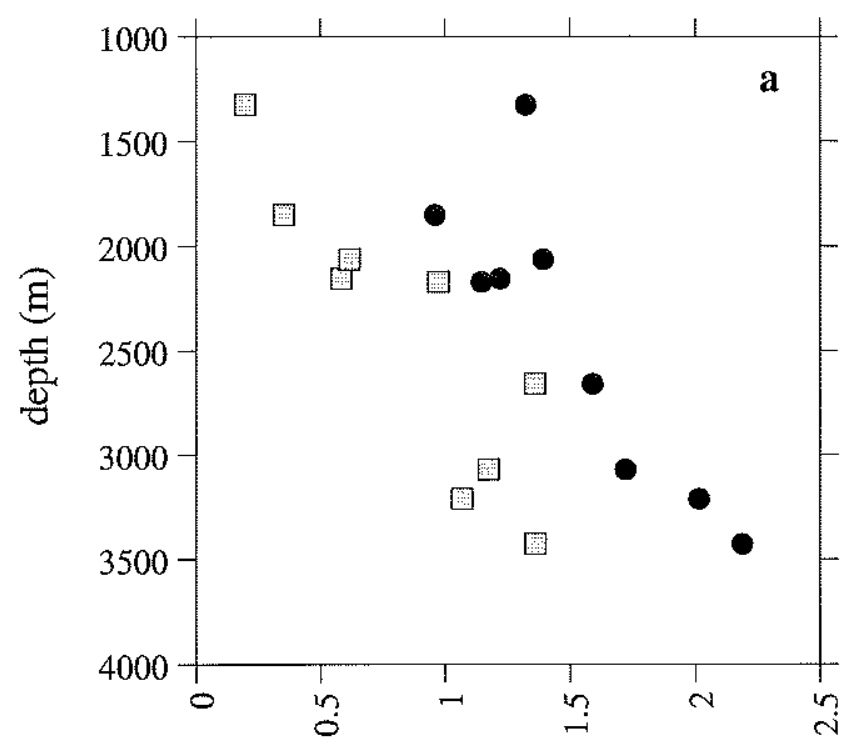

LGM equivalent $[\mathrm{P}]\left(\mu \mathrm{mol} \mathrm{\textrm {kg } ^ { - 1 }}\right)$

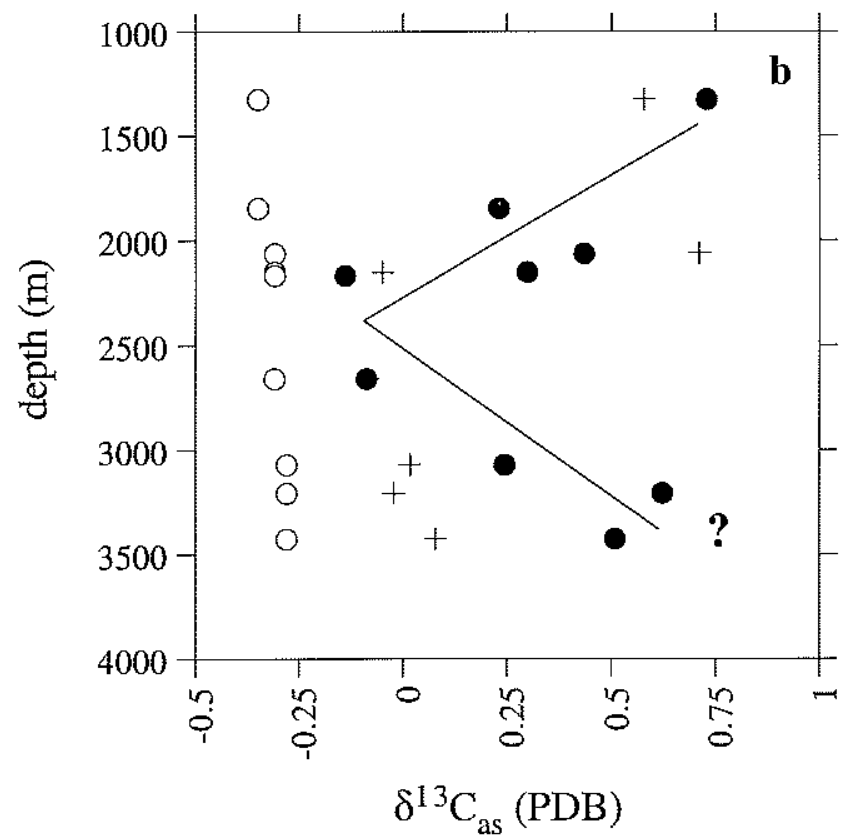

Figure 4.15. (a) LGM seawater dissolved $\mathrm{P}$ estimates based on published $\delta^{13} \mathrm{C}$ (squares) and $C$. wuellerstorfi $\mathrm{Cd} / \mathrm{Ca}$ from this study (circles). (b) $\delta^{13} \mathrm{C}_{\text {as }}$ estimates based on modern water column data (open circles; Lynch-Stieglitz and Fairbanks, 1994) and on the LGM data in panel (a) (filled circles). Lines represent a possible LGM relationship, but it is questionable whether or not the deepest $\delta^{13} \mathrm{C}_{\text {as }}$ estimates are accurate. Note that the Holocene foraminifera from these cores (crosses) do not give a good match to the modern water column data, mainly because of $\mathrm{Cd} / \mathrm{Ca}$ values that are higher than expected. 
Table 4.1. Core locations

\begin{tabular}{lrrr}
\hline core & depth & latitude & longitude \\
\hline V29-193 & 1326 & $55.40^{\circ}$ & $-18.73^{\circ}$ \\
V29-204 & 1849 & $61.18^{\circ}$ & $-23.02^{\circ}$ \\
V28-73 & 2063 & $57.18^{\circ}$ & $-20.87^{\circ}$ \\
CHN82-15PC & 2153 & $43.37^{\circ}$ & $-28.23^{\circ}$ \\
ODP 980 & 2168 & $55.48^{\circ}$ & $-14.70^{\circ}$ \\
V29-202 & 2658 & $60.38^{\circ}$ & $-20.97^{\circ}$ \\
CHN82-20PG/C & 3070 & $43.50^{\circ}$ & $-29.87^{\circ}$ \\
CHN82-11PG/C & 3209 & $42.38^{\circ}$ & $-31.80^{\circ}$ \\
CHN82-4PG/C & 3427 & $41.72^{\circ}$ & $-32.85^{\circ}$ \\
\hline
\end{tabular}


Table 4.2. Previous benthic $\delta^{13} \mathrm{C}(\% \mathrm{PDB})$ and $\mathrm{Cd} / \mathrm{Ca}\left(\mu \mathrm{mol} \mathrm{mol}^{-1}\right)$ data

\begin{tabular}{|c|c|c|c|c|c|c|c|}
\hline core & $\begin{array}{r}\text { depth } \\
\text { (m) }\end{array}$ & $\begin{array}{r}\text { Holocene } \\
\text { depth }(\mathrm{cm})\end{array}$ & $\begin{array}{r}\text { Holocene } \\
\delta^{13} \mathrm{C}\end{array}$ & $\begin{array}{l}\text { Holocene } \\
\mathrm{Cd} / \mathrm{Ca}\end{array}$ & $\begin{array}{r}\text { LGM } \\
\text { depth (cm) }\end{array}$ & $\begin{array}{r}\text { LGM } \\
\delta^{13} \mathrm{C}\end{array}$ & $\begin{array}{l}\mathrm{LGM} \\
\mathrm{Cd} / \mathrm{Ca}\end{array}$ \\
\hline V29-193 & 1326 & $0.5-20,31.5$ & 1.29 & & $55-70$ & 1.52 & \\
\hline$V 29-204^{b}$ & 1849 & $5-51$ & 1.24 & & $201-235$ & 1.37 & \\
\hline$V 28-73^{a}$ & 2063 & $3.5-15$ & 1.17 & & $43-64$ & 1.16 & \\
\hline CHN82-15PC ${ }^{\mathrm{c}, \mathrm{d}}$ & 2153 & 2 & 0.96 & 0.051 & $27-31$ & 1.19 & 0.041 \\
\hline ODP $980^{\circ}$ & 2168 & $1-24$ & 1.04 & & $402-442$ & 0.82 & \\
\hline$V 29-202^{f}$ & 2658 & $4-21,31$ & 1.07 & & $100-114$ & 0.45 & \\
\hline $\mathrm{CHN} 82-20 \mathrm{PG} / \mathrm{C}^{\mathrm{d}, \mathrm{g}, \mathrm{h}}$ & 3070 & $4-10$ & 1.23 & 0.073 & $73-87$ & 0.66 & 0.101 \\
\hline CHN82-11PC & 3209 & $4-8$ & 1.18 & 0.052 & $73-98$ & 0.76 & 0.100 \\
\hline CHN82-4PC ${ }^{\mathrm{d}, \mathrm{g}}$ & 3427 & $1-4$ & 1.11 & 0.074 & $58-64$ & 0.48 & 0.111 \\
\hline
\end{tabular}

Superscripts on core names indicate data sources: (a) Oppo and Lehman, 1993; (b) Curry et al., in press; (c) Boyle and Keigwin, 1987; (d) Boyle, 1992; (e) McManus et al., 1999; (f) Oppo and Lehman, 1995; (g) Boyle and Keigwin, 1985/6; (h) Boyle, 1988; (i) Boyle and Keigwin, 1982. For CHN82 cores, listed depths are for $\mathrm{Cd} / \mathrm{Ca}$ and are not necessarily the same as $\delta^{13} \mathrm{C}$ depths. Italicized $\delta^{13} \mathrm{C}$ value is mean of $2 \mathrm{~cm}$ and 6 $\mathrm{cm}$ samples listed in Boyle and Keigwin (1987); Boyle (1992) used the $2 \mathrm{~cm}$ value only $\left(0.63 \%\right.$ ). $\delta^{13} \mathrm{C}$ data are from $C$. wuellerstorfi and $C$. kullenbergi. $\mathrm{Cd} / \mathrm{Ca}$ data are from $C$. wuellerstorfi, $C$. kullenbergi, and Uvigerina. 
Table 4.3. Trace metal data from this study, grouped by species

\begin{tabular}{|c|c|c|c|c|c|}
\hline & sample depth $(\mathrm{cm})$ & {$[\mathrm{Ca}]$} & $\mathrm{Zn} / \mathrm{Ca}$ & $\mathrm{Cd} / \mathrm{Ca}$ & $\mathrm{Mn} / \mathrm{Ca}$ \\
\hline \multicolumn{6}{|l|}{ C. wuellerstorfi } \\
\hline \multirow[t]{2}{*}{ V29-193 (1326 m) } & $0-15(\mathrm{H})$ & 28.60 & 2.08 & 0.068 & 50.0 \\
\hline & $60-65(\mathrm{G})$ & 24.07 & 1.40 & 0.040 & 68.6 \\
\hline \multirow[t]{2}{*}{$\mathrm{V} 29-204(1849 \mathrm{~m})$} & $15-20(\mathrm{H})$ & 4.69 & 1.22 & 0.018 & 66.9 \\
\hline & $205(\mathrm{G})$ & 13.98 & 1.37 & 0.038 & 226.9 \\
\hline \multirow{6}{*}{$\mathrm{V} 28-73(2063 \mathrm{~m})$} & $3-4(\mathrm{H})$ & 15.03 & 3.62 & 0.102 & 44.9 \\
\hline & $3-4(\mathrm{H})$ & 12.95 & 3.00 & 0.119 & 48.1 \\
\hline & $10(\mathrm{H})$ & 8.77 & 2.38 & 0.134 & 34.8 \\
\hline & $10(\mathrm{H})$ & 13.82 & 2.48 & 0.112 & 44.6 \\
\hline & $43(\mathrm{G})$ & 22.33 & 2.15 & 0.064 & $\mathrm{nr}$ \\
\hline & $43(\mathrm{G})$ & 21.45 & 1.99 & 0.061 & $\mathrm{nr}$ \\
\hline \multirow[t]{5}{*}{ CHN82-15PC (2153 m) } & $0-6(\mathrm{H})$ & 15.05 & 1.96 & 0.075 & 13.7 \\
\hline & $0-6(\mathrm{H})$ & 7.88 & 2.26 & 0.080 & 9.3 \\
\hline & $0-6(\mathrm{H})$ & 12.94 & 3.48 & 0.127 & 16.1 \\
\hline & $0-6(H)$ & 17.31 & 2.40 & 0.079 & 13.2 \\
\hline & $31(\mathrm{G})$ & 26.11 & 2.51 & 0.055 & 11.0 \\
\hline ODP $980(2168 \mathrm{~m})$ & $63-64,84-86(\mathrm{G})$ & 10.15 & 1.82 & 0.052 & nr \\
\hline \multirow[t]{2}{*}{ V29-202 (2658 m) } & $26-54(\mathrm{H})$ & 23.89 & 1.32 & 0.080 & 170.8 \\
\hline & $107-108(\mathrm{G})$ & 10.15 & 4.09 & 0.099 & 198.3 \\
\hline \multirow[t]{4}{*}{ CHN82-20PG/C $(3070 \mathrm{~m})$} & $3-9(\mathrm{H})$ & 11.21 & 1.64 & 0.082 & 18.5 \\
\hline & $3-9(\mathrm{H})$ & 11.43 & 1.55 & 0.083 & 17.6 \\
\hline & $80-82(\mathrm{G})$ & 22.91 & 2.91 & 0.116 & 69.0 \\
\hline & $80-82(\mathrm{G})$ & 24.96 & 3.06 & 0.134 & 60.3 \\
\hline \multirow[t]{3}{*}{ CHN82-11PG/C (3209 m) } & $6-8(\mathrm{H})$ & 14.51 & 1.70 & 0.084 & 13.7 \\
\hline & $74-76(\mathrm{G})$ & 19.85 & 3.62 & 0.160 & 43.6 \\
\hline & $74-76(\mathrm{G})$ & 22.95 & 4.13 & 0.157 & 39.6 \\
\hline \multirow[t]{3}{*}{ CHN82-4PG/C $(3427 \mathrm{~m})$} & $0-3(\mathrm{H})$ & 15.20 & 1.64 & 0.097 & 23.4 \\
\hline & $0-3(\mathrm{H})$ & 17.90 & 1.65 & 0.106 & 27.7 \\
\hline & $57-61(\mathrm{G})$ & 4.20 & 3.65 & 0.179 & 73.7 \\
\hline \multicolumn{6}{|l|}{ Uvigerina spp. } \\
\hline V29-193 (1326 m) & $0-1(\mathrm{H})$ & 11.48 & 3.56 & 0.153 & 9.2 \\
\hline \multirow{2}{*}{$\mathrm{V} 28-73(2063 \mathrm{~m})$} & $3-4(\mathrm{H})$ & 14.55 & 2.46 & 0.133 & 15.2 \\
\hline & $10(\mathrm{H})$ & 7.90 & 2.58 & 0.118 & 8.3 \\
\hline \multirow[t]{2}{*}{ CHN82-20PC (3070 m) } & $80-82(\mathrm{G})$ & 14.50 & 3.13 & 0.106 & 10.3 \\
\hline & $80-82(\mathrm{G})$ & 18.40 & 2.33 & 0.107 & 12.8 \\
\hline \multirow[t]{2}{*}{ CHN82-11PC (3209 m) } & $74-76(\mathrm{G})$ & 12.51 & 2.68 & 0.131 & 3.2 \\
\hline & $74-76(\mathrm{G})$ & 13.82 & 2.59 & 0.132 & 5.1 \\
\hline \multirow[t]{2}{*}{ CHN82-4PC (3427 m) } & $57-61(\mathrm{G})$ & 15.66 & 2.25 & 0.123 & 20.3 \\
\hline & $57-61(\mathrm{G})$ & 13.95 & 2.20 & 0.121 & 17.0 \\
\hline
\end{tabular}




\begin{tabular}{llcccr}
\hline & sample depth $(\mathrm{cm})$ & {$[\mathrm{Ca}]$} & $\mathrm{Zn} / \mathrm{Ca}$ & $\mathrm{Cd} / \mathrm{Ca}$ & $\mathrm{Mn} / \mathrm{Ca}$ \\
\hline C. kullenbergi /pachyderma & & & & & \\
V29-193 $(1326 \mathrm{~m})$ & $0-1(\mathrm{H})$ & 18.03 & 4.77 & 0.077 & 15.5 \\
CHN82-15PC $(2153 \mathrm{~m})$ & $0-6(\mathrm{H})$ & 28.58 & 7.41 & 0.084 & 7.0 \\
CHN82-11PG $(3209 \mathrm{~m})$ & $6-8(\mathrm{H})$ & 16.86 & 7.93 & 0.062 & 5.8 \\
CHN82-4PG $(3427 \mathrm{~m})$ & $0-3(\mathrm{H})$ & 25.04 & 9.08 & 0.073 & 6.5 \\
& $0-3(\mathrm{H})$ & 17.27 & 9.91 & 0.055 & 6.0 \\
\hline
\end{tabular}

Samples considered to be Holocene denoted by $(\mathrm{H})$, glacial samples denoted by $(\mathrm{G})$. Underlined data are believed to be contaminated. "nr" means sample was not run due to insufficient volume. $[\mathrm{Ca}]$ is given in $\mathrm{mM}$, and ratios are in $\mu \mathrm{mol} / \mathrm{mol}$. 
Table 4.4. Circulation model parameters for four deepest cores

\begin{tabular}{rrrrrrrrr}
\hline modern & & & aged & aged & NADW & \multicolumn{2}{c}{ NADW proportion } \\
depth & local P & local Si & NADW P & NADW Si & P aging & Si aging & SOW \\
\hline & 2658 & 1.00 & 11 & 0.99 & 9.9 & 0.29 & 5.9 & 0.009 \\
3070 & 1.18 & 18 & 1.13 & 12.7 & 0.43 & 8.7 & 0.045 \\
3209 & 1.19 & 19 & 1.13 & 12.7 & 0.43 & 8.7 & 0.054 \\
3427 & 1.19 & 21 & 1.10 & 12.1 & 0.40 & 8.1 & 0.075
\end{tabular}

\begin{tabular}{rrrrrrrrrr} 
& & \multicolumn{4}{c}{ preformed preformed } & \multicolumn{3}{c}{ predicted } \\
preformed & depth & $\mathrm{Cd} / \mathrm{Ca}$ & $\mathrm{Cd}$ & local P & NADW P & NADW Si & local Si & $\mathrm{Zn}_{\mathrm{W}}$ & $\mathrm{Zv} / \mathrm{Ca}$ \\
\hline 2658 & 0.099 & 0.380 & 1.59 & 1.30 & 13 & 19.9 & 1.82 & 1.64 \\
3070 & 0.125 & 0.431 & 1.72 & 1.27 & 12.5 & 26.1 & 2.14 & 1.93 \\
3209 & 0.159 & 0.548 & 2.01 & 1.57 & 17 & 31.3 & 2.41 & 2.17 \\
3427 & 0.179 & 0.617 & 2.19 & 1.78 & 21 & 36.7 & 2.70 & 2.43
\end{tabular}

\begin{tabular}{|c|c|c|c|c|c|c|c|c|c|}
\hline aging & depth & $\mathrm{Cd} / \mathrm{Ca}$ & $\mathrm{Cd}_{\mathrm{W}}$ & local $\mathrm{P}$ & $\begin{array}{c}\text { NADW } \\
\text { P aging }\end{array}$ & $\begin{array}{r}N A D W \\
\text { Si aging }\end{array}$ & local Si & $\mathrm{Zn}_{\mathrm{W}}$ & $\begin{array}{r}\text { edicted } \\
\mathrm{Zn} / \mathrm{Ca}\end{array}$ \\
\hline & 2658 & 0.099 & 0.380 & 1.59 & 0.89 & 18.2 & 23.2 & 1.99 & 1.79 \\
\hline & 3070 & 0.125 & 0.431 & 1.72 & 0.99 & 20.4 & 29.2 & 2.30 & 2.07 \\
\hline & 3209 & 0.159 & 0.548 & 2.01 & 1.30 & 26.7 & 36.0 & 2.66 & 2.39 \\
\hline & 3427 & 0.179 & 0.617 & 2.19 & 1.48 & 30.4 & 41.6 & 2.95 & 2.65 \\
\hline
\end{tabular}

\begin{tabular}{rrrrrrrrr} 
& \multicolumn{9}{c}{ proportion } & \multicolumn{2}{r}{ predicted } \\
mixing & depth & $\mathrm{Cd} / \mathrm{Ca}$ & $\mathrm{Cd}_{\mathrm{W}}$ & local P & SOW & local Si & $\mathrm{Zn}_{\mathrm{W}}$ & $\mathrm{Zn} / \mathrm{Ca}$ \\
\hline 2658 & 0.099 & 0.380 & 1.59 & 0.454 & 64.4 & 4.13 & 3.72 \\
3070 & 0.125 & 0.431 & 1.72 & 0.497 & 71.1 & 4.48 & 4.03 \\
3209 & 0.159 & 0.548 & 2.01 & 0.744 & 100.0 & 5.98 & 5.39 \\
3427 & 0.179 & 0.617 & 2.19 & 0.891 & 117.2 & 6.88 & 6.19
\end{tabular}

\begin{tabular}{crrrrrr} 
mixing, accounting for $\left[\mathrm{CO}_{3}{ }^{2-}\right]$ & $\begin{array}{r}\text { modern } \\
{\left[\mathrm{CO}_{3}{ }^{2-}\right]}\end{array}$ & $\begin{array}{rrrr}\text { modern } \\
\Delta \mathrm{CO}_{3}{ }^{2-}\end{array}$ & $\begin{array}{r}\mathrm{LGM} \\
{\left[\mathrm{CO}_{3}{ }^{2-}\right]}\end{array}$ & $\begin{array}{r}\mathrm{LGM} \\
\Delta \mathrm{CO}_{3}{ }^{2-}\end{array}$ & $\begin{array}{r}\text { predicted } \\
\mathrm{Dn}_{\mathrm{Zn}}\end{array}$ & predicted \\
$\mathrm{Zn} / \mathrm{Ca}$ \\
\hline 100 & 29 & 91.0 & 20.0 & 8.25 & 3.41 \\
& 102 & 23 & 91.6 & 12.6 & 7.14 & 3.20 \\
& 104 & 23 & 86.5 & 5.5 & 6.07 & 3.63 \\
& 107 & 23 & 83.2 & -0.8 & 5.13 & 3.53 \\
\hline
\end{tabular}

Modern NADW preformed $\mathbf{P}$ is $0.70 \mu \mathrm{mol} \mathrm{kg}{ }^{-1}$ and preformed $\mathrm{Si}$ is $4.0 \mu \mathrm{mol} \mathrm{kg}^{-1}$. Aged SOW end member $P$ is $2.32 \mu \mathrm{mol} \mathrm{kg}$ and Si is $130 \mu \mathrm{mol} \mathrm{kg}^{-1} . \mathrm{Cd} / \mathrm{Ca}$ values are as measured in LGM C. wuellerstorfi. For each model, parameters in italics are solved for by holding other parameters constant (see text). Glacial SOW end member $\left[\mathrm{CO}_{3}{ }^{2-}\right]$ is assumed to have been $80 \mu \mathrm{mol} \mathrm{kg}{ }^{-1}$. Dissolved $\mathrm{P}, \mathrm{Si},\left[\mathrm{CO}_{3}{ }^{2-}\right]$, and $\Delta \mathrm{CO}_{3}{ }^{2-}$ are given in $\mu \mathrm{mol} \mathrm{kg}{ }^{-1} ; \mathrm{Cd}_{\mathrm{W}}$ and $\mathrm{Zn}_{\mathrm{W}}$ in $\mathrm{nmol} \mathrm{\textrm {kg } ^ { - 1 }}$; and $\mathrm{Cd} / \mathrm{Ca}$ and $\mathrm{Zn} / \mathrm{Ca}$ in $\mu \mathrm{mol} \mathrm{mol}{ }^{-1}$. 


\section{Summary}

The main contribution of this thesis is the introduction of benthic foraminiferal $\mathrm{Zn} / \mathrm{Ca}$ as a new tracer of ocean paleochemistry. $\mathrm{Zn} / \mathrm{Ca}$ is shown to be a function of bottom water dissolved $\mathrm{Zn}$ concentrations and also of bottom water saturation state with respect to calcite $\left(\Delta \mathrm{CO}_{3}{ }^{2-}\right)$. Dissolution experiments and measurements on recently living benthic foraminifera suggest that the $\Delta \mathrm{CO}_{3}{ }^{2-}$ effect occurs during growth, rather than being caused by a post mortem loss of $\mathrm{Zn} . \mathrm{Cd} / \mathrm{Ca}$ appears to be affected by $\Delta \mathrm{CO}_{3}{ }^{2-}$ to a different degree, so the two tracers can be used together to separate the influences of changing bottom water nutrient and $\mathrm{CO}_{3}{ }^{2-}$ levels.

In the deep eastern equatorial Pacific, $\mathrm{Zn} / \mathrm{Ca}$ and $\mathrm{Cd} / \mathrm{Ca}$ suggest that over the past $100,000 \mathrm{yr}\left[\mathrm{CO}_{3}{ }^{2-}\right]$ was lowest during glacial MIS 4 and highest during the last deglaciation. Estimates of $\mathrm{LGM}\left[\mathrm{CO}_{3}{ }^{2-}\right]$ and $\mathrm{pH}$ are not much different from today. Together these observations are consistent with a transfer of $\Sigma \mathrm{CO}_{2}$ from the upper ocean into the deep ocean during glacial times, producing a $\mathrm{CaCO}_{3}$ compensation effect that helped to lower atmospheric $\mathrm{CO}_{2}$ concentrations (Boyle, 1988). The data argue against a pore water dissolution mechanism (via increased $\mathrm{C}_{\text {org }}: \mathrm{CaCO}_{3}$ rain ratios) for lowering atmospheric $\mathrm{CO}_{2}$ (Archer and Maier-Reimer, 1994; Sanyal et al., 1995). Such constraints are crucial for understanding the natural controls on this important "greenhouse" gas.

Paired $\mathrm{Zn} / \mathrm{Ca}$ and $\mathrm{Cd} / \mathrm{Ca}$ data from the deep North Atlantic require the northward penetration of SOW during the LGM. This should help to quell any doubts about the glacial reduction of NADW formation. In addition, the data provide estimates of $\left[\mathrm{CO}_{3}{ }^{2-}\right]$ reductions caused by the presence of SOW. Although $\mathrm{Cd} / \mathrm{Ca}$ and $\delta^{13} \mathrm{C}$ agree reasonably well at the Bahama Banks, there are large apparent discrepancies in the higher-latitude

North Atlantic. Some of these data can be explained by increased $\delta^{13} \mathrm{C}_{\mathrm{as}}$ in GNAIW, but the deepest data seem to require extreme nutrient enrichments in the deep Southern Ocean. A better understanding of the relationship between $\mathrm{Cd} / \mathrm{Ca}$ and $\Delta \mathrm{CO}_{3}{ }^{2-}$ is necessary for the accurate reconstruction of deep ocean nutrient patterns. 
There is a tremendous amount of potential for future work with $\mathrm{Zn} / \mathrm{Ca}$. A high priority is to better constrain the glacial oceanic inventory of dissolved $\mathrm{Zn}$. As described in Chapter 2, this can be accomplished by measuring $\mathrm{Zn} / \mathrm{Ca}$ in Holocene and LGM samples from a variety of water depths in the Pacific. Records of $\mathrm{Zn} / \mathrm{Ca}$ and $\mathrm{Cd} / \mathrm{Ca}$ across Termination $\mathrm{I}$ in some of these cores will also provide a better estimate of the deglacial $\left[\mathrm{CO}_{3}{ }^{2-}\right]$ peak. Sites with lower modern $\Delta \mathrm{CO}_{3}{ }^{2-}$ levels than ODP 849 will allow $\mathrm{Zn} / \mathrm{Ca}$ to have a greater range of sensitivity, thus helping to determine if the $\left[\mathrm{CO}_{3}{ }^{2-}\right]$ peak was significantly more than $\sim 29 \mu \mathrm{mol} \mathrm{kg}{ }^{-1}$ higher than today. In the Atlantic, paired $\mathrm{Zn} / \mathrm{Ca}$ and $\mathrm{Cd} / \mathrm{Ca}$ can be used to evaluate the severity of $\mathrm{ACO}_{3}{ }^{2-}$ influences on benthic records, which may be especially important in the deep Southern Ocean.

The biological importance of $\mathrm{Zn}$ opens an additional avenue of research. $\mathrm{Zn}$ and $\mathrm{CO}_{2}$ can be co-limiting for diatom growth because $\mathrm{Zn}$ is required for the production of carbonic anhydrase, the enzyme used to convert $\mathrm{HCO}_{3}{ }^{-}$to $\mathrm{CO}_{2}$ (Morel et al., 1994; Sunda and Huntsman, 1995). Since coccolithophores make little or no use of carbonic anhydrase, low $\mathrm{Zn}$ levels allow coccolithophores to dominate over diatoms, resulting in low $\mathrm{C}_{\text {org }}: \mathrm{CaCO}_{3}$ ratios and an inefficient biological pump. These observations led Morel et al. (1994) to propose a "zinc hypothesis" (analogous to Martin and Fitzwater's [1988] "iron hypothesis"), whereby dust-borne $\mathrm{Zn}$ may have raised $\mathrm{C}_{\text {org }}: \mathrm{CaCO}_{3}$ rain ratios in glacial oceans and drawn down atmospheric $\mathrm{CO}_{2}$ levels. Elevated $\mathrm{Zn}$ concentrations in glacial surface waters might be recorded by planktonic foraminifera. Although modern surface water $\mathrm{Zn}$ levels in most of the world's oceans are extremely low, Southern Ocean waters are enriched enough (up to $\sim 5 \mathrm{nmol} \mathrm{kg}^{-1}[\mathrm{Zn}]$; Martin et al., 1990) for the calibration of planktonic foraminiferal $\mathrm{Zn} / \mathrm{Ca}$ ratios. Planktonic $\mathrm{Zn} / \mathrm{Ca}$ may also help to constrain the end member $\mathrm{Zn}$ compositions of various glacial water masses.

Finally, $\mathrm{Zn} / \mathrm{Ca}$ may be a useful proxy in other biogenic carbonates, such as corals and mollusks. In particular, deep sea corals have been shown to be unique archives of ultra-high-resolution deep water [Cd] changes (Adkins et al., 1998), and may offer similar records for seawater $[\mathrm{Zn}]$. Overall, $\mathrm{Zn} / \mathrm{Ca}$ is a very promising paleoceanographic tool. 


\section{References}

Adkins, J. F., H. Cheng, E. A. Boyle, E. R. M. Druffel, and R. L. Edwards, Deep-sea coral evidence for rapid change in ventilation of the deep North Atlantic 15,400 years ago, Science, 280, 725-728, 1998.

Archer, D., and E. Maier-Reimer, Effect of deep-sea sedimentary calcite preservation on atmospheric $\mathrm{CO}_{2}$ concentration, Nature, 367, 260-263, 1994.

Boyle, E. A., The role of vertical chemical fractionation in controlling Late Quaternary atmospheric carbon dioxide, J. Geophys. Res., 93, 15701-15714, 1988.

Martin, J. H., and S. E. Fitzwater, Iron deficiency limits phytoplankton growth in the north-east Pacific subarctic, Nature, 331, 341-343, 1988.

Martin, J. H., R. M. Gordon, and S. E. Fitzwater, Iron in Antarctic waters, Nature, $345,156-158,1990$.

Morel, F. M. M., J. R. Reinfelder, S. B. Roberts, C. P. Chamberlain, J. G. Lee, and D. Yee, Zinc and carbon co-limitation of marine phytoplankton, Nature, 369, 740$742,1994$.

Sanyal, A., N. G. Hemming, G. N. Hanson, and W. S. Broecker, Evidence for a higher $\mathrm{pH}$ in the glacial ocean from boron isotopes in foraminifera, Nature, 373, 234-236, 1995.

Sunda, W. G., and S. A. Huntsman, Cobalt and zinc interreplacement in marine phytoplankton: Biological and geochemical implications, Limnol. Oceanogr., 40, 1404-1417, 1995. 


\section{Appendix 1. Analytical methods and precision}

Foraminiferal samples were cleaned following the methods of Boyle and Keigwin (1985/6). The process includes clay removal using distilled water and methanol, metal oxide reduction using anhydrous hydrazine in a buffered solution, organic matter oxidation using hydrogen peroxide in a sodium hydroxide solution, and leaching with weak $(0.001 \mathrm{~N}$ and/or $0.075 \mathrm{~N})$ nitric acid. The sequence of reduction before oxidation is a modification introduced by Rosenthal (1994) to remove authigenic sulfides (Boyle and Rosenthal, 1996). To avoid laboratory contamination of $\mathrm{Zn}$, great care must be taken to avoid dust particles. Only the steps involving hydrazine were performed outside of laminar flow benches, and the entire lab was kept as dust-free as possible.

Clean samples were dissolved in $100 \mu 1$ of $0.075 \mathrm{~N}$ nitric acid. This gives enough volume for one [Ca] measurement $(10 \mu \mathrm{l})$, two [Zn] measurements $(17 \mu \mathrm{l} \mathrm{each})$, two [Cd] measurements $(18 \mu \mathrm{l} \mathrm{each})$, and one $[\mathrm{Mn}]$ measurement $(8 \mu \mathrm{l})$. Note that these volumes were varied slightly throughout the course of this study. Ca was measured by atomic absorption spectrophotometry (AAS) using an acetylene-air flame. $\mathrm{Zn}$ and $\mathrm{Cd}$ were measured by graphite furnace AAS using non-pyrolized cuvettes, and Mn was measured using pyrolized cuvettes. Measurement parameters and temperature programs for $\mathrm{Zn}, \mathrm{Cd}$, and $\mathrm{Mn}$ are listed in Tables A1.1 and A1.2. No significant interferences from Ca were found for either $\mathrm{Zn}$ or $\mathrm{Cd}$ using these parameters (Figure A1.1), so no corrections were made.

$\mathrm{Zn}, \mathrm{Cd}$, and $\mathrm{Mn}$ concentrations were calculated relative to four standards (ZO0$\mathrm{Z30}$ ) in a $\mathrm{CaNO}_{3}$ matrix (standard curve method). Three consistency standards (ZCS1ZCS3) were measured during each run, normally twice each. Two process blanks (empty sample tubes treated exactly like samples throughout the cleaning and measurement process) were also normally run. Consistency standards and process blanks over the course of 23 runs are shown in Figure A1.2 and Table A1.3. Mn consistency is relatively poor because of the small injection volumes (6-8 $\mu \mathrm{l})$ and the lack of replicates. Note that the $\mathrm{Zn} / \mathrm{Ca}$ process blank standard deviation is significantly higher than those of the consistency standards. This is due to occasional contamination during the cleaning 
process (see Figure A1.2). Omitting the single most contaminated process blank reduces the $\mathrm{Zn} / \mathrm{Ca}$ standard deviation to $\pm 0.16 \mu \mathrm{mol} \mathrm{mol}^{-1}$.

Finally, consistency with the Boyle lab was recently tested by running several of Boyle's standards (as samples) for $[\mathrm{Ca}]$ and [Cd]. The results suggest no significant offset between the two labs (Figure A1.3). 


\section{References}

Boyle, E. A., and L. D. Keigwin, Comparison of Atlantic and Pacific paleochemical records for the last 215,000 years: changes in deep ocean circulation and chemical inventories, Earth Planet. Sci. Lett., 76, 135-150, 1985/6.

Boyle, E. A., and Y. Rosenthal, Chemical hydrography of the South Atlantic during the last glacial maximum: $\mathrm{Cd}$ vs. $\delta^{13} \mathrm{C}$, in The South Atlantic: Present and Past Circulation, edited by G. Wefer et al., pp. 423-443, Springer-Verlag, Berlin, 1996.

Rosenthal, Y., Late Quaternary paleochemistry of the Southern Ocean: Evidence from cadmium variability in sediments and foraminifera, Ph.D. thesis, Mass. Inst. of Technol./Woods Hole Oceanogr. Inst. Joint Program in Oceanogr., Cambridge, MA, 1994 

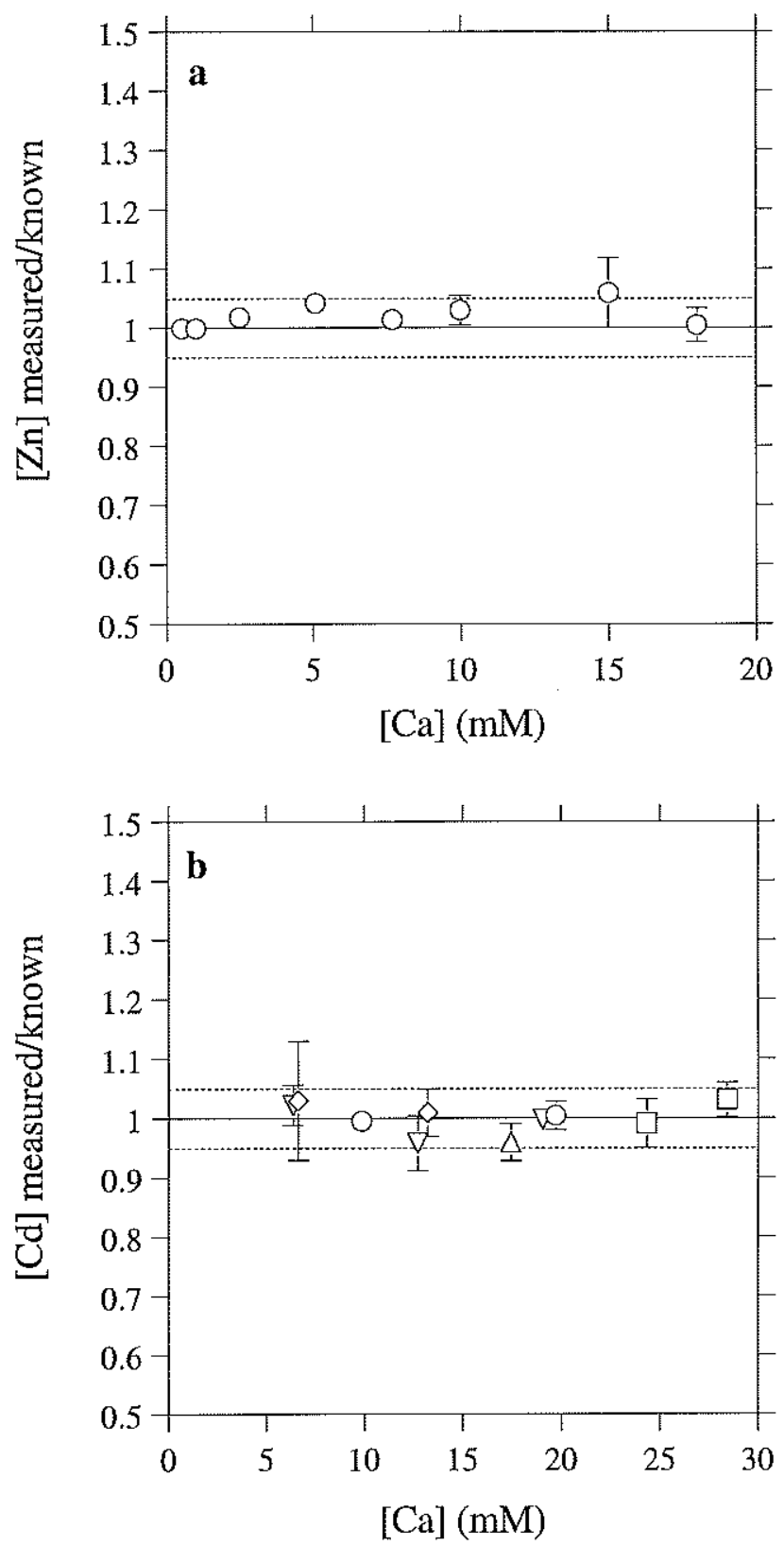

Figure A1.1. Tests for $\mathrm{Ca}$ interferences on $\mathrm{Zn}$ (a) and $\mathrm{Cd}$ (b) measurements by GFAAS, using parameters listed in Tables A1.1 and A1.2. $\mathrm{Zn}$ and $\mathrm{Cd}$ are given as measured concentrations divided by known (independently determined) concentrations. [Ca] was varied by diluting with $0.075 \mathrm{~N}$ nitric acid. Samples were as follows: Oppo lab Cd-Mn standards (circles; spiked with $\mathrm{Zn}$ in [a]); Oppo lab Cd-Mn consistency standards (squares); Oppo lab Zn-Cd-Mn standards (diamonds); Boyle lab Cd-Mn standards (upright triangle); Boyle lab ARS Cd-Mn consistency standard (inverted triangles). Error bars are $+/-1 \sigma$ of replicates. Dotted lines show $+/-5 \%$ envelope. 

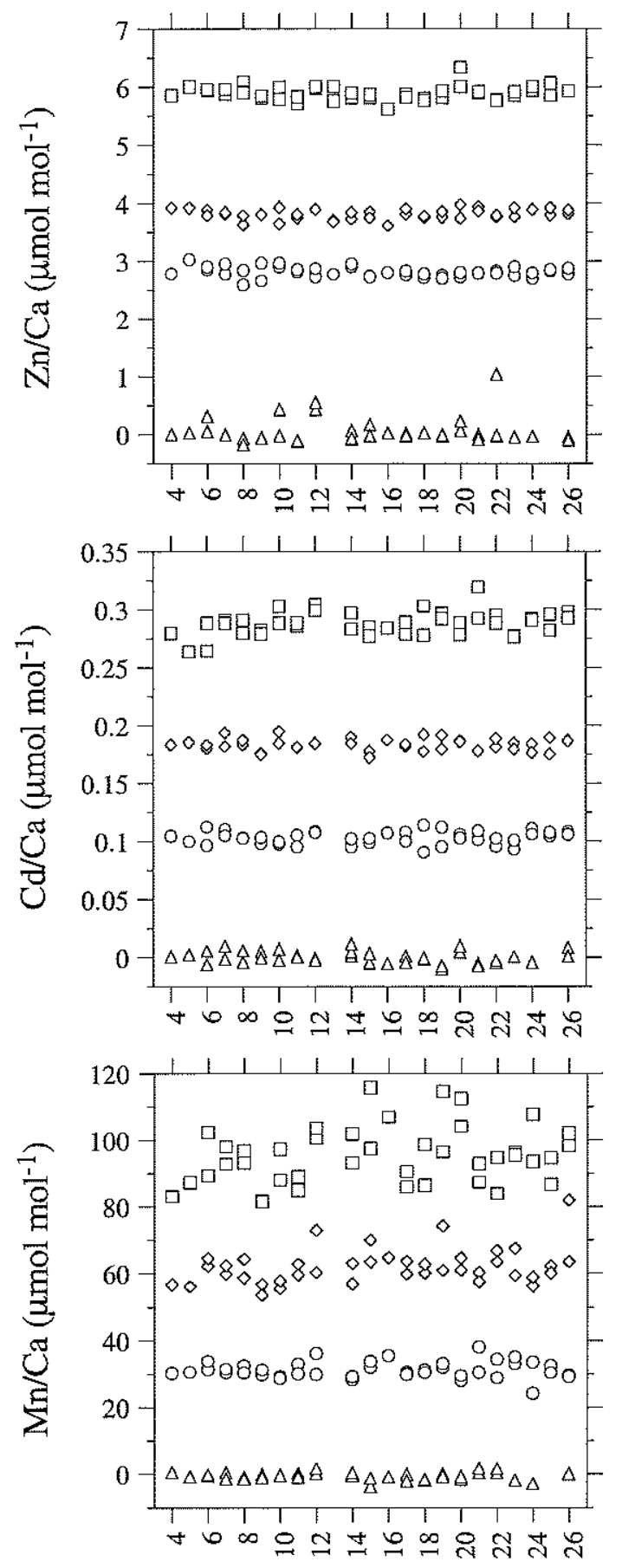

run number

Figure A1.2. Measurements made on consistency standards ZCS3 (squares), ZCS2 (diamonds), and ZCS1 (circles). Also shown are process blanks (triangles), plotted using a Ca concentration of $15 \mathrm{mM}$. Two ZCS Zn/Ca measurements are omitted (see Table A1.3). 


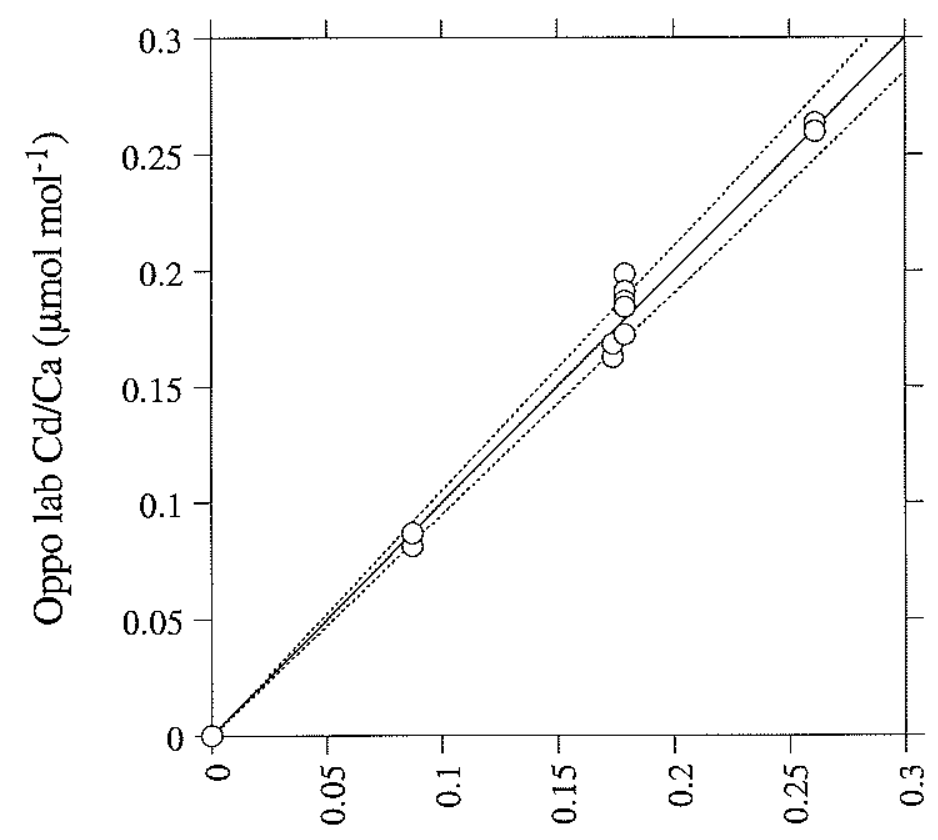

Boyle lab Cd/Ca $\left(\mu \mathrm{mol} \mathrm{mol}^{-1}\right)$

Figure A1.3. $\mathrm{Cd} / \mathrm{Ca}$ ratios measured in Oppo lab (using $\mathrm{Zn}-\mathrm{Cd}-\mathrm{Mn}$ standards Z00-Z30) vs. ratios measured by Boyle. Samples are Boyle's Cd-Mn standards (S00-S30) and Boyle's Cd-Mn consistency standard (ARS). Dotted lines are $+/-5 \%$ envelope. 
Table A1.1. GFAAS measurement parameters

\begin{tabular}{lrrr}
\hline & $\mathrm{Zn}$ & $\mathrm{Cd}$ & $\mathrm{Mn}$ \\
\hline wavelength $(\mathrm{nm})$ & 213.9 & 228.8 & 403.1 \\
slit width (nm) & 1.30 & 1.30 & 0.40 \\
PMT voltage (V) & 430 & 440 & 400 \\
lamp current (mA) & 7.0 & 7.5 & 7.5 \\
cuvette type & tube & tube & tube A \\
temperature control & optical & optical & optical \\
injection volume $(\mu \mathrm{l})$ & 17 & 18 & 8 \\
sample replicates & 2 & 2 & 1 \\
time constant $(\mathrm{s})$ & 0.20 & 0.20 & 0.10 \\
calculation method & peak area & peak area & peak height
\end{tabular}


Table A1.2. GFAAS temperature programs

\begin{tabular}{|c|c|c|c|c|c|c|c|}
\hline & stage \# & stage & start $\left({ }^{\circ} \mathrm{C}\right)$ & end $\left({ }^{\circ} \mathrm{C}\right)$ & $\operatorname{ramp}(\mathrm{s})$ & hold (s) & gas $(\mathrm{ml} / \mathrm{min})$ \\
\hline \multirow[t]{6}{*}{$\mathrm{Zn}$} & 1 & dry & 80 & 140 & 20 & & 200 \\
\hline & 2 & ash & 300 & 300 & & 25 & 200 \\
\hline & 3 & ash & 1000 & 1000 & & 4 & 200 \\
\hline & 4 & atom & 2000 & 2000 & & 4 & 70 \\
\hline & 5 & clean & 2700 & 2700 & & 4 & 200 \\
\hline & 6 & cool & & & & 5 & 200 \\
\hline \multirow[t]{5}{*}{$\mathrm{Cd}$} & 1 & dry & 50 & 150 & 15 & 5 & 200 \\
\hline & 2 & ash & 150 & 300 & 15 & 7 & 200 \\
\hline & 3 & atom & 2400 & 2400 & & 4 & 0 \\
\hline & 4 & clean & 2800 & 2800 & & 4 & 200 \\
\hline & 5 & cool & & & & 5 & 200 \\
\hline \multirow[t]{6}{*}{$\mathrm{Mn}$} & 1 & dry & 60 & 80 & 4 & 5 & 200 \\
\hline & 2 & dry & 80 & 150 & 15 & 5 & 200 \\
\hline & 3 & ash & 150 & 1100 & 15 & 10 & 200 \\
\hline & 4 & atom & 2400 & 2400 & & 4 & 30 \\
\hline & 5 & clean & 2800 & 2800 & & 6 & 200 \\
\hline & 6 & cool & & & & 5 & 200 \\
\hline
\end{tabular}


Table A1.3. Consistency standards and process blanks

\begin{tabular}{|c|c|c|c|}
\hline runs $4-26$ & mean & std dev & RSD \\
\hline ZCS3 [Ca] (mM) & 15.51 & 0.15 & $0.98 \%$ \\
\hline ZCS2 [Ca] (mM) & 16.30 & 0.19 & $1.14 \%$ \\
\hline ZCS1 [Ca] (mM) & 16.33 & 0.15 & $0.91 \%$ \\
\hline PB $[\mathrm{Ca}](\mathrm{mM})$ & -0.01 & 0.03 & \\
\hline
\end{tabular}

\begin{tabular}{|llll|}
\hline ZCS3 [Zn] $(\mathrm{nM})$ & 91.5 & 1.7 & $1.81 \%$ \\
ZCS2 [Zn] $(\mathrm{nM})$ & 62.2 & 1.4 & $2.18 \%$ \\
ZCS1 [Zn] $(\mathrm{nM})$ & 46.0 & 1.3 & $2.93 \%$ \\
PB [Zn] $(\mathrm{nM})$ & 0.8 & 2.6 & \\
& & & \\
$\mathbf{Z C S 3 ~ Z n} / \mathrm{Ca}(\mu \mathrm{mol} / \mathrm{mol})$ & 5.90 & 0.12 & $2.01 \%$ \\
$\mathbf{Z C S 2 ~ Z n} / \mathrm{Ca}(\mu \mathrm{mol} / \mathrm{mol})$ & 3.82 & 0.09 & $2.30 \%$ \\
$\mathbf{Z C S 1 ~ Z n} / \mathrm{Ca}(\mu \mathrm{mol} / \mathrm{mol})$ & 2.82 & 0.09 & $3.18 \%$ \\
PB Zn/Ca $(\mu \mathrm{mol} / \mathrm{mol})^{*}$ & 0.06 & 0.23 & \\
\hline
\end{tabular}

\begin{tabular}{|llll|}
\hline ZCS3 [Cd] (nM) & 4.46 & 0.17 & $3.82 \%$ \\
ZCS2 [Cd] (nM) & 2.99 & 0.09 & $2.90 \%$ \\
ZCS1 [Cd] (nM) & 1.68 & 0.09 & $5.57 \%$ \\
PB [Cd] (nM) & 0.00 & 0.08 & \\
\hline
\end{tabular}

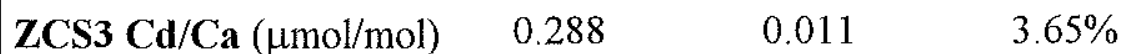

$\begin{array}{llll}\mathbf{Z C S} 2 \mathrm{Cd} / \mathrm{Ca}(\mu \mathrm{mol} / \mathrm{mol}) & 0.183 & 0.005 & 2.90 \%\end{array}$

$\mathrm{ZCS1} \mathrm{Cd} / \mathrm{Ca}(\mu \mathrm{mol} / \mathrm{mol}) \quad 0.103 \quad 0.006 \quad 5.45 \%$

PB Cd/Ca $(\mu \mathrm{mol} / \mathrm{mol})^{*} \quad 0.000 \quad 0.005$

\begin{tabular}{|llll|}
\hline ZCS3 [Mn] (nM) & 1477 & 134 & $9.07 \%$ \\
ZCS2 [Mn] (nM) & 1013 & 88 & $8.68 \%$ \\
ZCS1 [Mn] (nM) & 511 & 42 & $8.24 \%$ \\
PB [Mn] (nM) & -7 & 16 & \\
& & & \\
ZCS3 Mn/Ca $(\mu \mathrm{mol} / \mathrm{mol})$ & 95.3 & 8.7 & $9.13 \%$ \\
ZCS2 Mn $/ \mathrm{Ca}(\mu \mathrm{mol} / \mathrm{mol})$ & 62.2 & 5.4 & $8.73 \%$ \\
ZCS1 Mn $/ \mathbf{C a}(\mu \mathrm{mol} / \mathrm{mol})$ & 31.3 & 2.5 & $8.07 \%$ \\
PB Mn $/ \mathbf{C a}(\mu \mathrm{mol} / \mathrm{mol}) *$ & -0.5 & 1.1 & \\
\hline
\end{tabular}

Process blank (PB) elemental ratios are calculated using $[\mathrm{Ca}]=15 \mathrm{mM}$. Two consistency standard measurements that were badly contaminated in $\mathrm{Zn}$ are excluded from the means $(\mathrm{ZCS} 1 \mathrm{Zn} / \mathrm{Ca}=5.63 ; \mathrm{ZCS} 2 \mathrm{Zn} / \mathrm{Ca}=$ $6.52)$. RSD is relative standard deviation ( $1 \sigma /$ mean $)$. 


\section{Appendix 2. Calculations for the carbonate system in seawater}

The following pages contain an annotated Matlab ${ }^{\circledR}$ script for calculations of the carbonate system in seawater. It is primarily based on an Excel ${ }^{\circledR}$ spreadsheet provided by E. Boyle, and follows the recommendations of UNESCO (1987). Input parameters are water depth, temperature, salinity, alkalinity, and $\Sigma \mathrm{CO}_{2} . \Sigma \mathrm{CO}_{2}$ speciation is determined by solving for the first and second dissociation constants of carbonic acid, the dissociation constant of boric acid, and $\left[\mathrm{H}^{+}\right]$. The script returns $\left[\mathrm{CO}_{3}{ }^{2 n}\right]_{\text {in }}$ situ, $\left[\mathrm{CO}_{3}{ }^{2-}\right]_{\text {saturation }}$ with respect to calcite and aragonite, $\Delta \mathrm{CO}_{3}{ }^{2-}$ with respect to calcite and aragonite, $\mathrm{pH}$, and $p \mathrm{CO}_{2}$. 


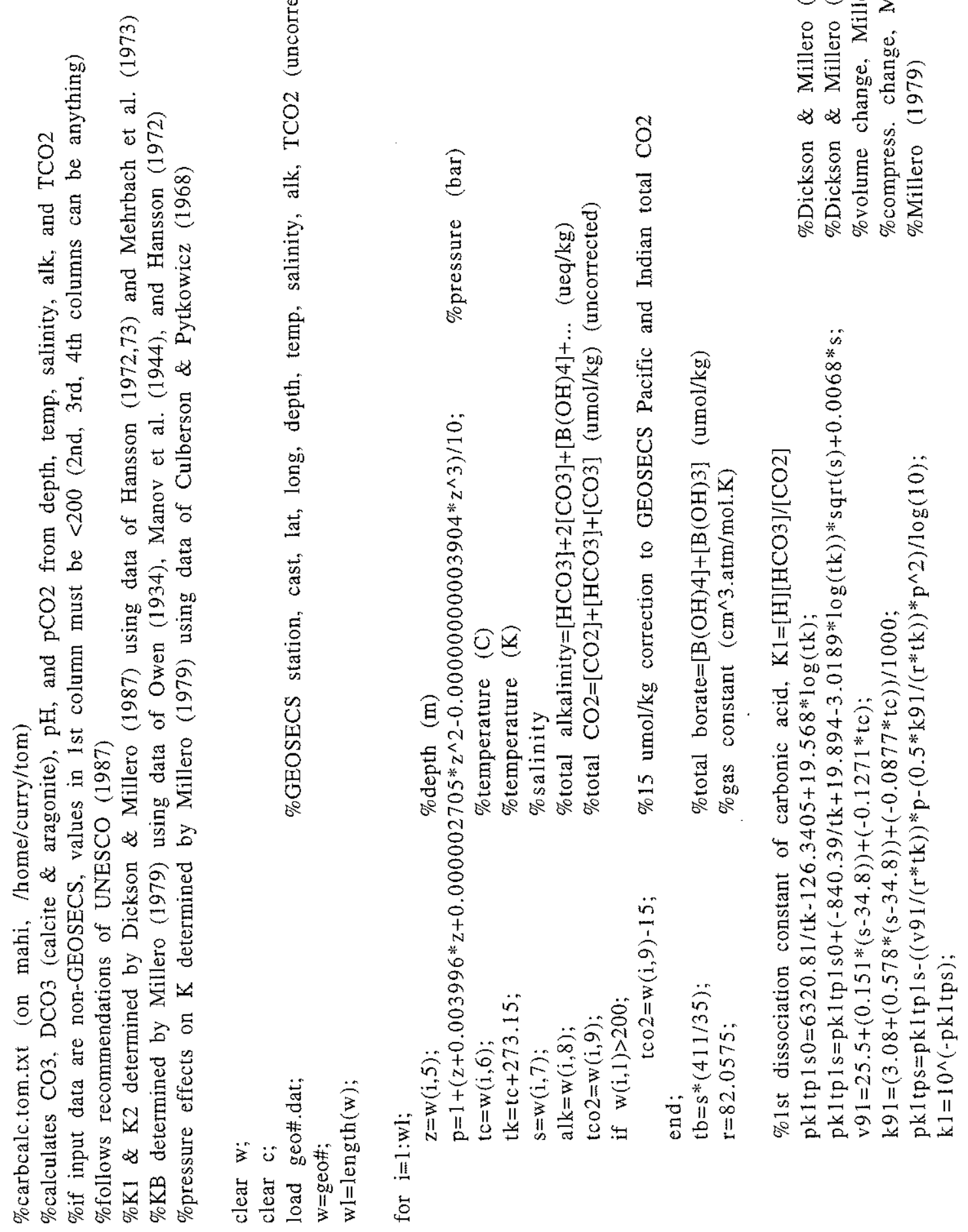



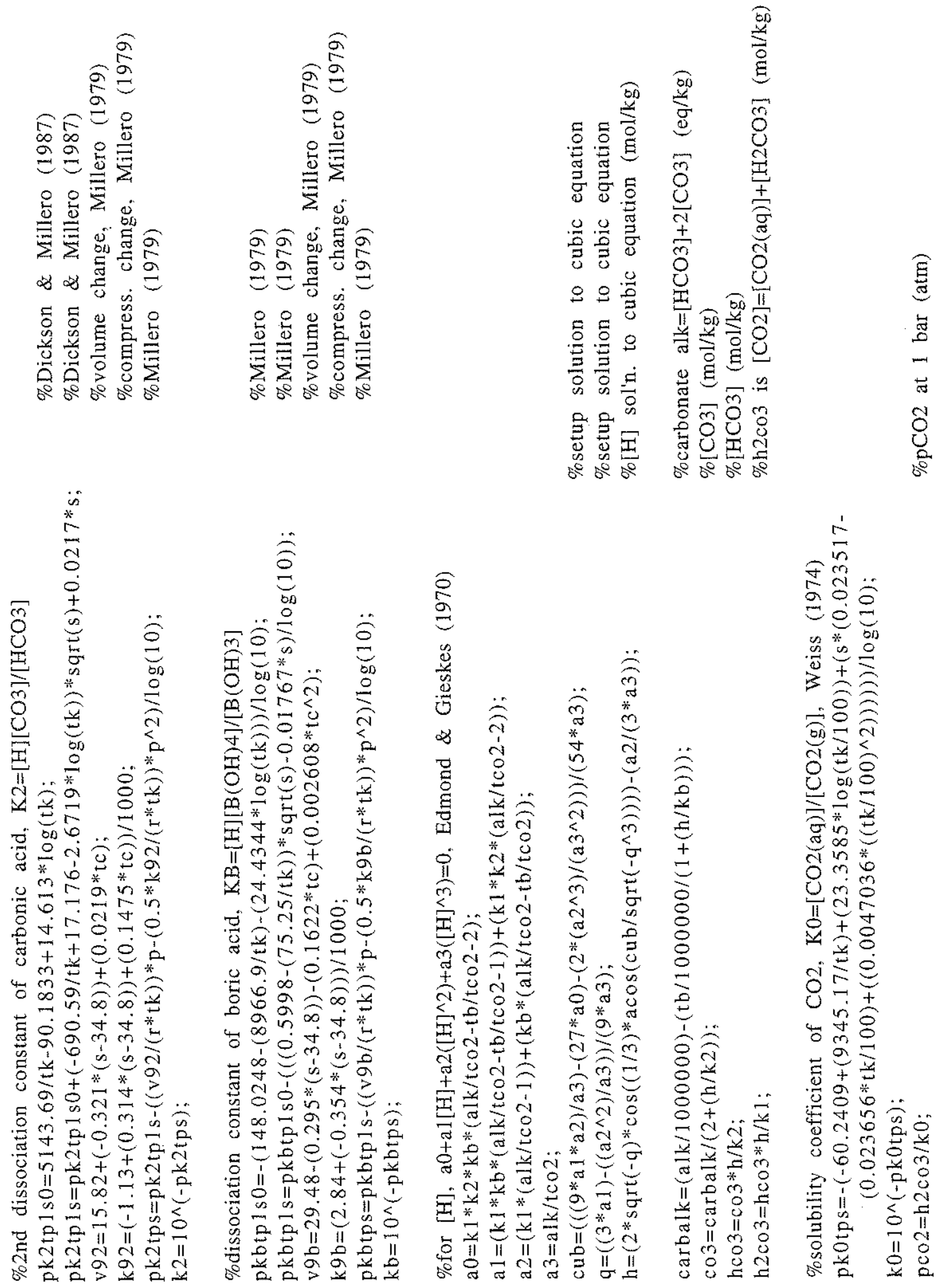


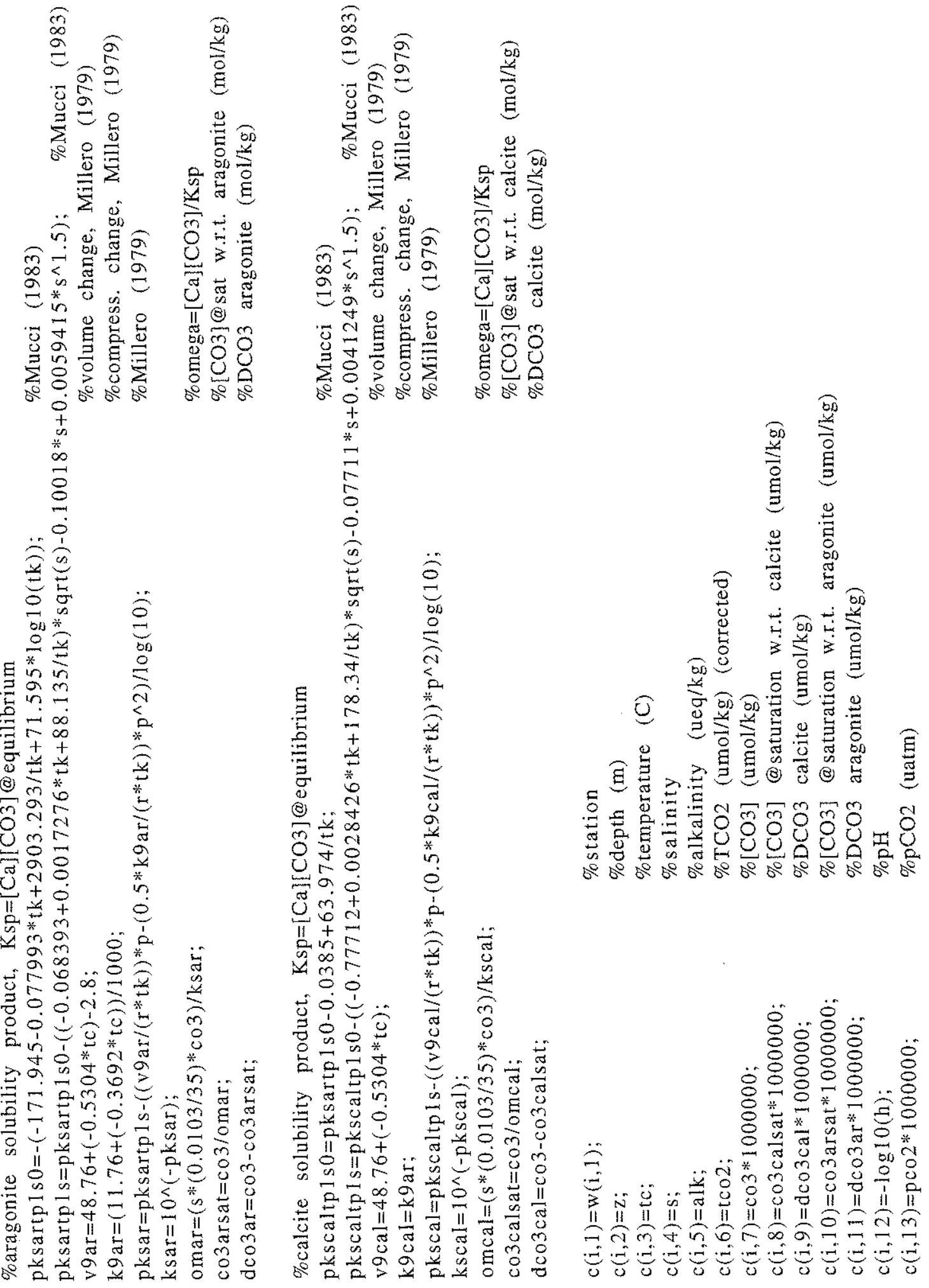




\section{References}

Culberson, C., and R. M. Pytkowicz, Effect of pressure on carbonic acid, boric acid, and the $\mathrm{pH}$ in seawater, Limnol. Oceanogr., 13, 403-417, 1968.

Dickson, A. G., and F. J. Millero, A comparison of the equilibrium constants for the dissociation of carbonic acid in seawater media, Deep Sea Res., 34, 1733-1743, 1987.

Edmond, J. M., and J. M. Gieskes, On the calculation of the degree of saturation of seawater with respect to calcium carbonate under in situ conditions, Geochim. Cosmochim. Acta, 34, 1261-1291, 1970.

Hansson, I., An analytical approach to the carbonate system in sea water, Ph.D. Thesis, Univ. of Göteborg, Sweden, 1972.

Hansson, I., A new set of acidity constants for carbonic acid and boric acid in sea water, Deep-Sea Res., 20, 461-478, 1973.

Manov, G. G., N. J. DeLollis, and S. F. Acree, Ionization constant of boric acid and the $\mathrm{pH}$ of certain borax-chloride buffer solutions from 0 to $60^{\circ} \mathrm{C}$, J. Res. Natn. Bur. Stds., 33, 287-306, 1944.

Mehrbach, C., C. H. Culberson, J. E. Hawley, and R. M. Pytkowicz, Measurement of the apparent dissociation constants of carbonic acid in seawater at atmospheric pressure, Limnol. Oceanogr., 18, 897-907, 1973.

Millero, F. J., The thermodynamics of the carbonate system in seawater, Geochim. Cosmochim. Acta, 43, 1651-1661, 1979.

Mucci, A., The solubility of calcite and aragonite in seawater at various salinities, temperatures, and one atmospheric total pressure, Amer. J. Sci., 283, 780-799, 1983.

Owen, B. B., The dissociation constant of boric acid from 10 to $50^{\circ}$, J. Am. Chem. Soc., 56, 1695-1697, 1934.

UNESCO, Thermodynamics of the carbon dioxide system in seawater, UNESCO Tech. Papers Mar. Sci., 5I, 1987.

Weiss, R. F., Carbon dioxide in water and seawater: the solubility of a non-ideal gas, Mar. Chem., 2, 203-215, 1974. 